UNIVERSIDADE DE SÃO PAULO

FACULDADE DE ECONOMIA, ADMINISTRAÇÃO E CONTABILIDADE DEPARTAMENTO DE CONTABILIDADE E ATUÁRIA PROGRAMA DE PÓS-GRADUAÇÃO EM CIÊNCIAS CONTÁBEIS

INFLUÊNCIA DOS SISTEMAS EMPRESARIAIS INTEGRADOS (ERPS) NOS ASPECTOS ORGANIZACIONAIS DA ÁREA DE CONTABILIDADE - ESTUDOS DE CASOS EM EMPRESAS DO PARANÁ -

Lílian Moreira de Alvarenga Assolari

Orientador: Prof. Dr. Edson Luiz Riccio 
Prof. Dr. Adolpho José Melfi

Reitor da Universidade de São Paulo

Profa. Dra. Maria Tereza Leme Fleury

Diretora da Faculdade de Economia, Administração e Contabilidade

Prof. Dr. Reinaldo Guerreiro

Chefe do Departamento de Contabilidade e Atuária

Prof. Dr. Fábio Frezatti

Coordenador do Programa de Pós-Graduação em Ciências Contábeis 
INFLUÊNCIA DOS SISTEMAS EMPRESARIAIS INTEGRADOS (ERPs) NOS ASPECTOS ORGANIZACIONAIS DA ÁREA DE CONTABILIDADE - ESTUDOS DE CASOS EM EMPRESAS DO PARANÁ -

Dissertação apresentada ao Departamento de Contabilidade e Atuária da Faculdade de Economia, Administração e Contabilidade da Universidade de São Paulo como requisito para a obtenção do título de Mestre em Ciências Contábeis.

Orientador: Prof. Dr. Edson Luiz Riccio 
Dissertação defendida e aprovada no Departamento de Contabilidade e Atuária da Faculdade de Economia, Administração e Contabilidade da Universidade de São Paulo - Programa de Pós-Graduação em Ciências Contábeis, pela seguinte banca examinadora:

Assolari, Lílian Moreira de Alvarenga

Influência dos sistemas empresariais integrados (ERP) nos aspectos organizacionais da área de Contabilidade : estudos de casos em empresas do Paraná / Lílian Moreira de Alvarenga Assolari -- São Paulo, 2005.

$211 \mathrm{p}$.

Dissertação (Mestrado) - Universidade de São Paulo, 2005

Bibliografia.

1. Sistemas de informação contábil 2. Sistemas ERP 3. Mudança organizacional I. Universidade de São Paulo. Faculdade de Economia, Administração e Contabilidade. II. Título.

CDD - 657.02854 
Ao meu esposo Gilmar, pelo amor e apoio incondicional em todos os momentos. Aos meus filhos Rafael e Rodrigo, luz dos meus dias. 
Agradeço a Deus, por seu infinito amor e misericórdia.

Ao meu orientador, Edson L. Riccio, que continuamente me encorajou, foi paciente e compreensível e prestou valiosas contribuições durante o desenvolvimento deste trabalho.

Aos professores do Departamento de Contabilidade da FEA-USP, pela participação de cada um para a minha formação.

Aos funcionários do Departamento de Contabilidade da FEA, secretaria de pósgraduação, biblioteca, UPD e FIPECAFI, por propiciar as condições essenciais para a realização do trabalho, em especial à Cristina e à Valéria.

Aos amigos do DCC/UEM, que me incentivaram e estiveram sempre prontos a me atender nos momentos difíceis do curso e do desenvolvimento deste trabalho. Agradeço em especial aos professores Mário Lonardoni, Alice de Fátima Rodrigues e Massakazu Takakura, por não terem medido esforços para viabilizar minha participação no curso de Mestrado.

Ao meu esposo Gilmar, que esteve sempre ao meu lado me encorajando, compreendendo minhas ausências, assumindo tantas responsabilidades, sendo por muitas vezes pai e mãe dos nossos filhos. Obrigada por seu amor e dedicação.

Aos meus pais Benedito e Carmem, que me ensinaram o valor do estudo e do trabalho, e que especialmente durante este curso estiveram ao meu lado, deixando seus afazeres para me auxiliar em tudo o que foi preciso. Obrigada pelo amor incondicional de vocês. Aos meus sogros Reinaldo (in memorian) e Enedina, que me acolheram em sua família como uma filha e que estiveram sempre me incentivando e auxiliando nos momentos de dificuldades.

Às minhas irmãs Leila e Gisele, e à minha tia Tereza, que me apoiaram e auxiliaram a vencer mais este desafio. Aos meus familiares Wagner, Leila, Pedro, Omar, Sandra, Jéssika, que, cada um a seu modo, contribuíram para a realização deste trabalho.

À amiga Patrícia Siqueira Varela, que dividiu tantas alegrias e tristezas durante o curso, sempre me apoiou e auxiliou em tudo o que foi preciso; ao amigo Márcio, que nunca me deixou desanimar; ao amigo Alcides, que me ajudou a enfrentar os desafios dessa jornada; e à amiga Roseli, que colocou a amizade acima de tudo e demonstrou seu comprometimento nos momentos difíceis.

Na impossibilidade de nominar a todos, agradeço àqueles que, de alguma forma, contribuíram para o cumprimento de mais esta etapa importante. 
“A sabedoria vem de Deus.” Livro da Sabedoria 


\section{RESUMO}

A decisão sobre implementar ou não um ERP (Sistema de Integrado de Gestão), conforme constatado na literatura consultada, não é apenas uma questão de tecnologia, mas fundamentalmente uma questão de estratégia; isso porque sua implementação demanda profundas mudanças na organização. De acordo com os resultados de algumas pesquisas já publicadas, especificamente na área de Contabilidade das organizações, a implementação do ERP provoca mudanças. Diante disso, esta pesquisa foi realizada com o objetivo de compreender e descrever a influência da implantação do ERP nos aspectos organizacionais da área de Contabilidade das empresas, mais precisamente no que se refere às mudanças na estrutura organizacional, às atividades desenvolvidas e aos conhecimentos e habilidades exigidos para a execução das atividades. Em atenção aos propósitos da pesquisa, o trabalho foi construído por meio de uma abordagem metodológica empírico-analítica com a condução de Estudos de Casos nas empresas do Estado do Paraná. Para tanto, foram analisados dois casos referentes a empresas que implementaram o ERP R/3 do fornecedor SAP. A análise dos dados indica que a implementação do ERP provoca, na área de Contabilidade das empresas, alterações na estrutura organizacional, nas atividades e nos conhecimentos e habilidades. As alterações verificadas na estrutura organizacional referem-se ao design organizacional, à estrutura de cargos e ao quadro de funcionários. Quanto às atividades, as alterações estão relacionadas ao tipo de atividade desenvolvida na área (inclusão ou exclusão) e à forma de desenvolvê-las. Com relação aos conhecimentos e habilidades, as alterações dizem respeito aos conhecimentos gerais, técnicos, habilidades intelectuais, interpessoais e de comunicação. Porém, depreende-se da análise dos dados, que a implementação de um ERP influencia mais diretamente as atividades e, como conseqüência, a estrutura organizacional e os conhecimentos e habilidades sofrem reflexos e precisam ser ajustados, ou seja, a intensidade das alterações na estrutura organizacional e nos conhecimentos e habilidades está relacionada à profundidade das mudanças ocorridas nas atividades. Todavia, embora o ERP tenha potencial para alterar as atividades, as mudanças variam de empresa para empresa, pois a implementação do ERP, por si, não promove sempre as mesmas mudanças; a natureza e a profundidade das mudanças dependem das decisões tomadas pelos responsáveis pela empresa e pela equipe de projeto, durante a fase de implementação do ERP e também posteriormente, quando o sistema já está sendo utilizado. 


\begin{abstract}
According to literature in the area, the decision about whether or not to implement ERP (Enterprise Resource Planning) is not a matter of technology alone, but rather, a matter of strategy, since its implementation requires deep changes in the organization. Still according to research already published, this implementation generates deep changes in the area of accounting of organizations as well. Due to this fact, this research was carried out aiming at understanding and describing the influence of the implementation of ERP on the organizational aspects in the area of accounting of enterprises, particularly in what concerns the changes in structure, activities developed, besides knowledge and abilities required for the carrying out of tasks. Seeking to achieve the purpose of this research, the procedures followed an empirical analytical methodological approach as a guideline to Case Studies carried out in enterprises in the State of Paraná. The analysis took into account two cases of enterprises that implemented ERP R/3 by SAP (supplier of software solutions for enterprises). The analysis of data shows that the implementation of ERP gives rise to changes not only in the organizational structure but also in activities and in knowledge and abilities within the accounting area of enterprises. The changes found within the organizational structure allude to organizational design, job designs and personnel. As far as activities go, changes are related to the kind of activity performed in the area (inclusion or exclusion), and to the way of performing them. Concerning knowledge and abilities, changes regard general and technical knowledge, and intellectual, interpersonal and communicative abilities. Nevertheless, the analysis of data leads to the understanding of the fact that ERP implementation acts more directly upon activities; thus, both the organizational structure and knowledge and abilities are affected as well, and need adjustments; that is to say, the intensity of changes operating on the organizational structure and on knowledge and abilities is related to the depth of the changes that have an effect on the activities. However, although ERP has the potential to alter activities, changes vary among enterprises, since the implementation itself does not always promote the same changes; both nature and depth of changes depend on decisions made by those responsible for the business and by the group in charge of the project, and not only during but also after ERP implementation, when the system is already in action.
\end{abstract}


LISTA DE ABREVIATURAS E SIGLAS

1 INTRODUÇÃO

1.1 Questão da Pesquisa

1.2 Objetivos da Pesquisa

1.2.1 Objetivo geral

1.2.2 Objetivos específicos 9

1.3 Justificativa 9

1.4 Estrutura do Trabalho 10

2 REFERENCIAL TEÓRICO 13

2.1 Sistemas Empresariais Integrados (ERP) 13

2.1.1 Conceituação e breve histórico 13

$\begin{array}{ll}\text { 2.1.2 Vantagens e problemas associados ao ERP } & 17\end{array}$

2.1.3 Riscos e fatores críticos de sucesso associados ao ERP 20

$\begin{array}{lll}2.1 .3 .1 & \text { Riscos } & 20\end{array}$

2.1.3.2 Fatores críticos de sucesso $\quad 22$

$\begin{array}{lll}2.1 .4 & \text { SAP } & 25\end{array}$

2.1.4.1 Gestão financeira (FI) 26

$\begin{array}{lll}\text { 2.1.4.2 Controladoria (CO) } & 27\end{array}$

2.2 Mudança Organizacional 28

2.2.1 Mudança organizacional e tecnologia da informação 28

2.2.2 Estrutura das organizações $\quad 32$

$\begin{array}{lll}\text { 2.2.2.1 Componentes } & 34\end{array}$

2.2.2.2 Determinantes 39

2.2.2.3 Design organizacional 43

$\begin{array}{lll}\text { 2.2.2.4 Estrutura de cargos } & 46\end{array}$

2.3 Sistema de Informações Contábeis 49

2.3.1 Objetivo da Contabilidade 49

2.3.2 Abordagem restrita versus abordagem expandida 52

2.3.2.1 Abordagem restrita 52

2.3.2.2 Abordagem expandida 53

2.3.3 Conhecimentos e habilidades necessários ao contador 62

$\begin{array}{lll}\text { 2.3.3.1 Conhecimentos } & 62\end{array}$

2.3.3.2 Habilidades $\quad 65$

3 METODOLOGIA DA PESQUISA 69

$\begin{array}{lll}3.1 & \text { Delineamento da Pesquisa } & 69\end{array}$

$\begin{array}{lll}3.2 & \text { Planejamento do Estudo de Casos } & 73\end{array}$

$\begin{array}{lll}\text { 3.2.1 Componentes do projeto de pesquisa } & 73\end{array}$

$\begin{array}{lll}\text { 3.2.1.1 Questão da pesquisa } & 73\end{array}$

$\begin{array}{lll}\text { 3.2.1.2 Proposições } & 73\end{array}$

3.2.1.3 Unidade de análise $\quad 74$

3.2.1.4 Critérios para análise dos dados $\quad 75$

$\begin{array}{lll}3.2 .2 & \text { Definição dos casos } & 75\end{array}$

$\begin{array}{lll}\text { 3.2.3 Protocolo da pesquisa } & 76\end{array}$

$\begin{array}{lll}\text { 3.2.3.1 Contato com a empresa } & 76\end{array}$

$\begin{array}{lll}\text { 3.2.3.2 Coleta de dados } & 78\end{array}$

$\begin{array}{lll}\text { 3.2.3.3 } & \text { Referencial de análise } & 79\end{array}$ 
3.2.3.4 Relatório do estudo de casos 81

3.3 Limitações da Pesquisa 82

4 APRESENTAÇÃO E ANÁLISE DOS RESULTADOS 85

4.1 Caso 1 - Empresa $1 \quad 85$

4.1.1 Contextualização $\quad 85$

4.1.2 Informações gerais sobre a implementação do R/3 86

4.1.3 Estrutura organizacional 86

$\begin{array}{lll}\text { 4.1.4 Atividades } & 89\end{array}$

$\begin{array}{lll}\text { 4.1.4.1 Contabilidade financeira } & 89\end{array}$

4.1.4.2 Contabilidade gerencial 91

4.1.5 Conhecimentos e habilidades 93

4.1.6 Análise $\quad 94$

4.1.6.1 Fatores críticos de sucesso (FCS) 94

4.1.6.2 Influência da implementação do ERP na estrutura organizacional 97

4.1.6.3 Influência da implementação do ERP nas atividades 98

4.1.6.4 Influência da implementação do ERP nos conhecimentos e habilidades 100

$\begin{array}{ll}\text { 4.1.6.5 Considerações finais } & 101\end{array}$

$\begin{array}{lll}4.2 & \text { Caso } 2 \text { - Empresa } 2 & 102\end{array}$

4.2.1 Contextualização 102

4.2.2 Informações gerais sobre a implementação do R/3 103

$\begin{array}{lll}4.2 .3 & \text { Estrutura organizacional } & 106\end{array}$

$\begin{array}{lll}4.2 .4 & \text { Atividades } & 110\end{array}$

$\begin{array}{lll}\text { 4.2.4.1 Contabilidade financeira } & 110\end{array}$

4.2.4.2 Contabilidade gerencial 113

4.2.5 Conhecimentos e habilidades 116

4.2.6 Análise 118

4.2.6.1 Fatores críticos de sucesso (FCS) 118

4.2.6.2 Influência da implementação do ERP na estrutura organizacional 121

4.2.6.3 Influência da implementação do ERP nas atividades 123

4.2.6.4 Influência da implementação do ERP nos conhecimentos e habilidades 126

$\begin{array}{ll}\text { 4.2.6.5 Considerações finais } & 127\end{array}$

$\begin{array}{lll}4.3 & \text { Caso } 3 \text { - Empresa } 3 & 128\end{array}$

4.4 Resultados de Outras Pesquisas Publicadas 131

4.4.1 Pesquisa realizada por Riccio (2001) 131

4.4.2 Pesquisa realizada por Carvalho Filho (2001) 133

4.5 Análise Comparativa 135

4.5.1 Alterações relacionadas à estrutura organizacional 140

$\begin{array}{lll}\text { 4.5.2 Alterações relacionadas às atividades } & 142\end{array}$

4.5.3 Alterações relacionadas aos conhecimentos e habilidades 147

5 CONCLUSÕES $\quad 149$

REFERÊNCIAS

APÊNDICES $\quad 161$

APÊNDICE $1+162$

APENNDICE $2 \quad 165$

APENNDICE $3 \quad 167$

APÊNDICE $4 \quad 169$

APÊNDICE $5 \quad 171$

$\begin{array}{ll}\text { APÊNDICE } 6 & 184\end{array}$ 


\section{LISTA DE ABREVIATURAS E SIGLAS}

ABC: Activity-Based Cost Accounting - Contabilidade por Custo Baseado em Atividades AM: Asset Management - Gerenciamento do Ativo Fixo

ASAP: Accelerated SAP

CAD: Computer Aided Design - Desenho Assistido por Computador

CAM: Computer Aided Manufacturing - Manufatura Assistida por Computador

CCA: Cost Center Accounting - Contabilidade por Centro de Custo

CIA: Centro de Informática Aplicada

CO: Controlling - Controladoria

COFINS: Contribuição para o Financiamento da Seguridade Social

CRM: Customer Relationship Management - Gerenciamento do Relacionamento com o Cliente

CVM: Comissão de Valores Mobiliários

E-COMMERCE: Comércio Eletrônico

ERP: Enterprise Resource Planning - Sistemas Integrados de Gestão

FCS: Fatores Críticos de Sucesso

FGV-EAESP: Fundação Getúlio Vargas - Escola de Administração de Empresas de São Paulo

FI: Financial Accounting - Gestão Financeira

GL: General Ledger - Contabilidade geral

IBRACON: Instituto Brasileiro de Contadores

ICMS: Imposto sobre Circulação de Mercadorias e sobre Prestação de Serviços de Transporte Interestadual e Intermunicipal e de Comunicação

IEG: International Education Guidelines - Diretrizes Internacionais de Educação

IFAC: International Federation of Accountants - Federação Internacional dos Contadores

INSS: Instituto Nacional de Seguridade Social

IPECAFI: Instituto de Pesquisa Contábeis, Atuariais e Financeiras

LC: Legal Consolidation - Consolidação

MRP: Material Requirements Planning - Planejamento das Necessidades de Materiais

O\&M: Organização e Métodos

OPA: Order and Project Accounting - Contabilidade por ordem e projeto

PA: Profitability Analysis - Análise de Rentabilidade

PC: Product Cost Accounting - Contabilidade de custo por produto

PCA: Profit Center Accounting - Contabilidade por Centro de Lucro

PIS: Plano de Integração Social

SAP: Systemanalyse and Programmentwicklung - Sistemas, Aplicações e Produtos para Processamento de Dados

SCM: Suply Chain Management - Gerenciamento da Cadeia de Suprimentos

SIC: Sistema de Informações Contábeis

SPL: Special Purpose Ledgers - Razões especiais

SPT: Sistema de Processamento de Transações

TI: Tecnologia da Informação 


\section{INTRODUÇÃO}

Historicamente, a tecnologia pode ser relacionada à evolução da sociedade. Isto fica claro se recordarmos que na primeira Revolução Industrial, no final do século XVIII, e posteriormente na segunda Revolução Industrial, já no final do século XIX, o desenvolvimento tecnológico contribuiu para a evolução de fatores como os processos de trabalho, as relações de trabalho e as filosofias de gestão, atingindo toda a sociedade e seu modo de vida.

Na segunda metade do século XX, mais uma vez a tecnologia marcou o início de uma nova fase, entendida por alguns como a terceira Revolução Industrial, mas também chamada de Era da Informação.

O extraordinário desenvolvimento tecnológico, especialmente da tecnologia da informação, contribuiu sobremaneira para tornar o ambiente das empresas globalizado e mais competitivo, o que ocorre num contexto de transformação econômica, social, política e cultural da sociedade.

Impulsionada pelas mudanças nesse ambiente, a gestão empresarial também sofreu transformações e passou a ter a informação como seu recurso essencial, sua principal fonte de energia, seu mais importante insumo.

Diversas tecnologias de informação (TI) surgiram para suprir essa necessidade, como por exemplo, datawarehouse, data mining, CAD (computer aided design), CAM (computer aided manufacturing), ERP (enterprise resource planning), sistemas de suporte à decisão, sistemas especialistas, SCM (suply chain management) e CRM (customer relationship management), entre outros.

Este trabalho tem como foco de estudo uma dessas tecnologias, os sistemas empresariais integrados (ERP), cujas premissas básicas são a existência de uma base de dados única e a integração de todas as atividades de uma empresa. Tal tecnologia de informação pode ser vista como um pacote que inclui diversos aplicativos, antes desenvolvidos separadamente para cada área ou função da organização. 
Os primeiros sistemas empresariais integrados surgiram na década de 70, para atender às demandas das empresas por integração de processos, maior eficiência, informações mais rápidas e confiáveis, entre outros, o que as tornariam mais competitivas. Riccio (2001, p. 38) comenta que "Os sistemas empresariais integrados têm sua origem na necessidade das empresas em gerir suas estruturas organizacionais, cada vez mais complexas e dinâmicas.”

Originalmente, o ERP integrava os processos organizacionais internos, com foco na eficiência. Todavia, com as mudanças ambientais ao longo do tempo, as empresas sentiram a necessidade de maior suporte do sistema para questões estratégicas e também de maior integração com seus parceiros externos, como fornecedores e clientes.

Uma das pesquisas que identificaram essa lacuna deixada pelo ERP é a de Hedman e Borell (2002). O estudo foi realizado com base no sistema R/3, versão 4.0b, da empresa SAP e os resultados demonstraram que o sistema era pouco eficiente quanto à interação com o ambiente externo das empresas e quanto ao relacionamento com recursos humanos.

Como sempre, acompanhando o progresso da sociedade e a necessidade das empresas, o sistema evoluiu. Na segunda geração de ERP foram incorporados vários aplicativos, que permitem integrações interorganizacionais como suply chain management e customer relationship management, além de ferramentas que proporcionam às empresas melhores condições de suporte às estratégias. É a evolução do ERP com a manutenção da sua característica essencial: a integração dos negócios.

Há expectativas de que as empresas cada vez mais caminhem para ambientes de sistemas integrados, inclusive as pequenas empresas.

Uma pesquisa da AMR Research, desenvolvida por Scott e Shepherd (2002) em 500 empresas de médio e grande porte, revelou que existe ainda um mercado promissor para o ERP. Aproximadamente dois terços dessas empresas já possuíam este sistema e, das que ainda não o possuíam, 21\% estavam avaliando algum dos softwares de ERP disponíveis no mercado. Destes, 15\% pretendiam iniciar a implementação nos próximos 12 meses (2003), assim que as condições econômicas permitissem. A pesquisa revelou que havia ainda espaço para novas implementações em diversos setores dos segmentos da indústria e serviços. Havia também oportunidades em todos os setores para atualizações e novos desenvolvimentos. 
No Brasil, a tendência parece ser a mesma. Hehn (1999, p. 64), sócio de uma empresa de consultoria especializada em processos de transformação associados a TI, comenta a introdução e as tendências do ERP no país:

No Brasil, eles foram inicialmente implementados pelas multinacionais, muitas vezes por decisão de suas matrizes. Logo as empresas nacionais de grande e médio porte perceberam suas vantagens e começaram a adotá-los. A previsão é que o mesmo ocorra com as de pequeno porte, consolidando um movimento onde integração é a palavra-chave.

Embora tenha sido considerado, num primeiro momento, a solução para todos os problemas de informação da empresa, o ERP, algumas vezes, não atendeu às expectativas iniciais. O fato é que estes sistemas provocam muitas mudanças nas organizações, que nem sempre estão preparadas para enfrentá-las. Walton (1993, p. 31) descreve algumas experiências com implementações de tecnologia avançada e comenta:

As formas de TI avançadas têm conseqüências organizacionais mais amplas e profundas do que as anteriores. Quanto maior a funcionalidade de um sistema de TI, maiores níveis de aprendizado e ajustamento são necessários para sua utilização, indo desde as habilidades dos operadores por meio dos procedimentos e estrutura organizacionais até os aspectos culturais.

O ERP surgiu e se mantém com a proposta de ser mais que um software para auxiliar na gestão. Sua implementação oferece à empresa uma nova filosofia de gestão empresarial.

[...] os ERPs representam uma profunda alteração no modo de operação. Com o ERP a maioria dos processos e conseqüentemente a infra-estrutura operacional e administrativa são alterados, afetando os procedimentos, métodos, relações interdepartamentais, políticas e enfim, a maneira de operar da empresa. (RICCIO, 2001, p. 13).

Assim, a decisão sobre implementar ou não um ERP não é apenas uma questão de tecnologia, mas fundamentalmente uma questão de estratégia. Isso porque sua implementação demanda muitas mudanças na organização.

Diversos autores como Davenport (1998), Caldas e Wood (2000), Walton (1993) e Bergamaschi (1999) demonstraram que muitos projetos fracassaram porque, ainda nas fases de planejamento e implementação, não foram observados esses impactos. Sendo assim é fundamental, na implementação de um ERP, proceder à revisão dos processos de trabalho, da estrutura, da qualificação dos funcionários, da cultura organizacional, do processo de comunicação, enfim, é necessário repensar toda a organização. 
Com a Contabilidade não é diferente. As pesquisas já realizadas sobre o tema, e que serviram de embasamento teórico para este estudo, demonstram que a implementação do ERP provocou mudanças na área de Contabilidade das empresas.

Os estudos de Riccio (2001), Carvalho Filho (2001), Granlund e Malmi (2002), Scapens (1998) identificaram que, nas empresas pesquisadas, o ERP provocou impactos na estrutura da Contabilidade, na imagem, nos processos operacionais, nas informações oferecidas, entre outros aspectos. Em alguns casos as mudanças foram pequenas; em outros foram mais significativas.

Todavia, pouco ainda se conhece sobre a Contabilidade nesse novo ambiente de sistema integrado apesar de, como comentado anteriormente, existir uma tendência de as empresas, cada vez mais, optarem por substituir seus aplicativos atuais por soluções integradas. Essa realidade demanda um conhecimento maior sobre as potencialidades e exigências do ERP para a Contabilidade, visando a otimização dos benefícios.

\subsection{Questão da Pesquisa}

Pretendeu-se com este estudo responder à seguinte questão orientadora de pesquisa:

Como a implantação dos ERPs influencia os aspectos organizacionais da área de Contabilidade referentes à estrutura organizacional, às atividades desenvolvidas e aos conhecimentos e habilidades necessários para a execução das atividades?

\subsection{Objetivos da Pesquisa}

Em consonância com a questão estabelecida, os objetivos preliminares do presente estudo foram: 


\subsubsection{Objetivo geral}

Compreender e descrever a influência da implantação dos ERP nos aspectos organizacionais da área de Contabilidade das empresas, especificamente quanto às mudanças na estrutura organizacional, atividades desenvolvidas e conhecimentos e habilidades exigidos para a execução das atividades.

\subsubsection{Objetivos específicos}

a) Quanto às mudanças relacionadas à estrutura organizacional:

Compreender as alterações no design organizacional, na estrutura de cargos e na quantidade de pessoas;

b) Quanto às mudanças relacionadas às atividades:

Compreender as alterações no tipo de atividade desenvolvida (inclusão ou exclusão de atividades) e na forma de desenvolver as atividades;

c) Quanto às mudanças relacionadas aos conhecimentos e habilidades exigidos para a execução das atividades:

Compreender as alterações nos conhecimentos técnicos, nos conhecimentos gerais e nas habilidades.

\section{$1.3 \quad$ Justificativa}

Embora os sistemas integrados estejam sendo utilizados há algum tempo e diversas pesquisas já tenham sido realizadas, muito ainda está para ser feito até que se compreenda melhor os reflexos que eles provocam nas organizações.

Stijn (2002) discute a relevância da pesquisa sobre ERP, com vistas à compreensão dos benefícios que sua implementação proporciona às empresas, e afirma que a pesquisa deste sistema é significativa. Em seu artigo, ele considera três dimensões do ERP, a tecnológica, a organizacional e a cognitiva. Segundo o autor, “[...] entendendo-os como um fenômeno tridimensional, fica claro que os sistemas ERP apresentam uma combinação de características 
específicas que os tornam diferentes de outros sistemas de informação [...]”1 (Ibid., p. 250).

No que se refere à pesquisa em Contabilidade, tendo em vista os sistemas integrados, poucos trabalhos foram desenvolvidos. Todavia, trabalhos dessa natureza parecem ser muito oportunos e de grande relevância, pois a maior compreensão sobre as mudanças provocadas pela implementação de um ERP poderia trazer diversas contribuições, tanto para a Contabilidade quanto para as empresas e a comunidade em geral.

Para os profissionais que já estão atuando nas empresas, como funcionários da Contabilidade, poderia trazer a possibilidade de utilizar melhor o potencial do ERP já implementado ou de auxiliar na análise da viabilidade de implementação. Aos profissionais envolvidos com ramos específicos da Contabilidade, como auditoria e consultoria externa, permitiria uma melhor qualificação para desempenhar suas atividades.

Aos discentes dos cursos de Contabilidade e áreas afins, possibilitaria maior qualificação para buscar espaço no mercado de trabalho e, para os responsáveis pelos cursos de graduação e pós-graduação relacionados à Contabilidade, forneceria melhores subsídios para analisarem se os currículos estão em consonância com as exigências do mercado. Também os pesquisadores seriam beneficiados com a ampliação da base de conhecimentos existente, a qual poderia auxiliar na análise de questões correntes ou em pesquisas futuras.

Por fim, as empresas teriam à sua disposição informações que poderiam contribuir para promover ajustes no alinhamento entre as estratégias do negócio, tecnologia da informação e organização.

\subsection{Estrutura do Trabalho}

Em atenção aos propósitos da pesquisa, este trabalho foi construído por meio de uma abordagem metodológica empírico-analítica com a condução de Estudos de Casos nas empresas do Estado do Paraná.

\footnotetext{
1 “Understanding them as three dimensional phenomena makes it clear that ERP systems exhibit a combination of specific characteristics that makes them distinct from other information systems [...]"
} 
Sua estrutura é composta por cinco capítulos. No capítulo 1 é desenvolvida a introdução, que contextualiza o trabalho, apresenta a caracterização do problema, a questão orientadora de pesquisa, os objetivos e a justificativa do estudo.

O capítulo 2 apresenta o embasamento teórico construído por meio da revisão da literatura relacionada ao tema com o intuito de dar sustentação teórica para a pesquisa de campo desenvolvida. Já o capítulo 3 aborda os procedimentos metodológicos quanto à estratégia de pesquisa utilizada - Estudo de Caso, incluindo o instrumento de planejamento da coleta de dados, o Protocolo do Estudo de Caso.

No capítulo 4, constam os dados e a análise dos resultados, procurando conciliar teoria e fontes de evidências dos Estudos de casos das empresas do estado do Paraná; e, no capítulo 5, são apresentadas as considerações finais do trabalho. 



\section{REFERENCIAL TEÓRICO}

\subsection{Sistemas Empresariais Integrados (ERP)}

\subsubsection{Conceituação e breve histórico}

Os sistemas empresariais integrados (ERP) têm como premissas básicas a existência de uma base de dados única e a integração de todas as atividades de uma empresa. A grosso modo, ele pode ser visto como um pacote que inclui diversos aplicativos, antes desenvolvidos separadamente para cada área ou função da empresa.

Para James Hall (2001, p. 548), o ERP tem por objetivo integrar todos os processos-chave da organização. No modelo tradicional de software, cada área tinha seu próprio sistema desenvolvido para atender suas necessidades do dia-a-dia. O ERP reúne tudo em um único sistema integrado que acessa um único banco de dados, o que facilita a disseminação da informação e melhora a comunicação por toda a empresa.

Todavia, a filosofia do ERP é mais que a junção de diversos aplicativos num único software. O enfoque do sistema é global e espelha a dinâmica da interação das atividades da empresa. Conforme comenta Riccio (2001, p. 2):

\footnotetext{
O ERP utiliza entre outros o princípio fundamental do enfoque sistêmico, ou seja, 'pensar primeiro sobre o objetivo global e em seguida começar a descrever o sistema em função desse objetivo global' (Churchman, 1972, p. 28) Assim, um ERP não é a junção de vários sistemas mas um todo concebido antes e de uma só vez.
}

Essa filosofia de sistema integrado surgiu da necessidade de as empresas acompanharem o desenvolvimento do ambiente onde atuam, executando suas atividades com maior dinamismo, qualidade, menor custo, entre outros. Era necessário um sistema que acompanhasse o ritmo da empresa.

O ERP é uma tecnologia relativamente recente. O desenvolvimento tecnológico concernente a banco de dados, telecomunicações e redes possibilitou a criação desse tipo de sistema, que 
surgiu na década de 90 e está em evolução.

Riccio (2001) apresenta uma descrição detalhada da origem e evolução do ERP. Neste trabalho, tendo por base este autor, apenas um breve retrospecto é apresentado.

Inicialmente, foi desenvolvido um sistema para integrar os processos da área de produção e foi chamado MRP (material requirements planning - planejamento das necessidades de materiais). Esse sistema evoluiu para o MRP II, o qual incluiu funcionalidades da área financeira, promovendo uma integração parcial das atividades da empresa. Todavia, ainda havia a necessidade de um sistema que incorporasse as atividades das demais áreas, afinal todas as atividades estão, de uma forma ou de outra, interligadas, são interdependentes.

Procurando atender essa demanda criou-se o ERP que, por sua origem, foi primeiramente chamado de planejamento dos recursos empresarias, mas hoje é entendido como sistemas empresariais integrados ou sistemas integrados de gestão, devido à amplitude de suas funcionalidades.

Em seu surgimento, a integração se limitava ao ambiente interno da empresa. Com a evolução do ERP foram incorporados vários aplicativos que permitem integrações interorganizacionais, tais como gerenciamento da cadeia de suprimentos (suply chain management) e gerenciamento do relacionamento com o cliente (customer relationship management), além de ferramentas que proporcionam às empresas melhores condições de suporte às estratégias, transformando-o em um sistema mais amplo e fortalecendo o relacionamento da empresa com fornecedores e clientes.

Esses aplicativos já estavam disponíveis no mercado, mas foram aos poucos sendo incorporados ao ERP, tendo em vista a demanda das empresas por maior integração dos seus processos. Entretanto, desde o início, a filosofia e a lógica do ERP se mantêm e suas características básicas continuam as mesmas, dando a sustentação a um pacote cada vez maior e mais complexo.

Dentre as características principais desse software podemos citar: 
a) Baseado no modelo cliente-servidor, geralmente, com ambiente em três camadas: uma camada contendo os softwares de apresentação, sediada geralmente em microcomputadores espalhados pela empresa (é a que os usuários visualizam); a segunda camada onde residem os aplicativos, sediada em computadores de grande capacidade chamados servidores; a terceira onde reside o banco de dados, também sediada em servidor;

b) Operação com banco de dados único: todos os dados são introduzidos uma única vez e armazenados em um único banco de dados que é acessado por todos os usuários, mediante autorização através de senha;

c) Formado por módulos: o sistema é um pacote que reúne diversos módulos, os quais geralmente são organizados em financeiro, vendas e logística, recursos humanos e produção;

d) Repositório de dados: dicionário de dados que contém informações sobre todos os dados da empresa, como, por exemplo, os atributos dos dados, as relações entre eles etc. “[...] serve primeiramente como ferramenta para inserir, gerenciar e avaliar informações sobre os dados da empresa.”2 (BANCROFT et al, 1998, p. 27).

Quanto aos fornecedores desse tipo de software, poucas empresas multinacionais são responsáveis pela maioria das implementações na esfera mundial. Dentre estas empresas a SAP é a líder, com grande vantagem de participação de mercado se comparada à Oracle, que ocupa a segunda posição. A Tabela 1 apresenta os principais fornecedores mundiais de ERP:

\footnotetext{
2 “ [...] serves primarily as a tool to enter, manage, and evaluate information about your company’s data.”
} 
Tabela 1 - Maiores fornecedores mundiais de ERP

(classificação de acordo com a receita de 2004)

\begin{tabular}{l|c|c}
\hline Fornecedores & $\begin{array}{c}\text { Participação no mercado } \\
\text { mundial em 2004 }\end{array}$ & $\begin{array}{c}\text { Participação no mercado } \\
\text { mundial projetada para 2005 }\end{array}$ \\
\hline SAP & $40 \%$ & $43 \%$ \\
\hline Oracle & $10 \%$ & $19 \%$ \\
\hline PeopleSoft* & $12 \%$ & $0 \%$ \\
\hline Sage Group & $5 \%$ & $4 \%$ \\
\hline Microsoft Business Solutions & $3 \%$ & $3 \%$ \\
\hline SSA Global & $3 \%$ & $2 \%$ \\
\hline Geac & $2 \%$ & $2 \%$ \\
\hline Lawtentia & $2 \%$ & $1 \%$ \\
\hline Infor Global Solutions & $2 \%$ & $2 \%$ \\
\hline
\end{tabular}

FONTE: AMR Research, 2005

*Oracle adquiriu PeopleSoft em dezembro de 2004

As empresas multinacionais dominam o mercado mundial, mas no mercado nacional as brasileiras já são competitivas. Segundo a pesquisa anual realizada pelo CIA - Centro de Informática Aplicada da FGV-EAESP, cuja edição referente ao período 2004/2005 contou com 60\% das maiores empresas do país segundo o ranking das Maiores e Melhores da revista Exame, as empresas brasileiras estão bastante competitivas no mercado nacional de ERP, onde a líder também é a empresa SAP.

As principais empresas brasileiras fornecedoras de ERP estão relacionadas na Tabela 2:

Tabela 2 - Maiores fornecedores nacionais de ERP (\% do número de empresas utilizando)

\begin{tabular}{l|c}
\hline Fornecedores & $\begin{array}{c}\text { Participação no mercado } \\
\text { nacional em 2004 }\end{array}$ \\
\hline Datasul & $16 \%$ \\
\hline Microssiga & $14 \%$ \\
\hline RM Sistemas & $7 \%$ \\
\hline FONTE: CIA - Centro de Informática Aplicada da FGV-EAESP, 2005
\end{tabular}

Atualmente os fornecedores estão voltando as atenções às pequenas e médias empresas, como alvo de seus produtos. Quando o ERP surgiu, o foco principal eram as grandes empresas, principalmente devido ao alto custo de aquisição e implementação. Com o passar do tempo, tanto os fornecedores quanto as empresas que implementaram este sistema foram adquirindo experiência, verificando suas vantagens e suas falhas e aperfeiçoando seus softwares, além de qualificar melhor seus funcionários e parceiros para prestarem consultoria nas implementações. 
Novas soluções foram surgindo, tornando os softwares mais acessíveis e cada vez mais empresas podem usufruir os benefícios trazidos pelo ERP, os quais serão comentados na seqüência.

\subsubsection{Vantagens e problemas associados ao ERP}

Diversos pesquisadores, como Riccio (2001), Davenport (1998), Hedman e Borell (2002), comentam sobre as vantagens do ERP para as empresas, as quais justificam a decisão de investir nesse tipo de sistema. Dentre as mais citadas estão:

a) integração do fluxo de informação;

b) integração dos processos de negócio da empresa;

c) eliminação da redundância de dados;

d) eliminação de dados em formatos diferentes;

e) padronização de processos, aumentando sua eficiência;

f) facilita a implementação das melhores práticas globais (best practices);

g) a empresa passa a ser orientada por processos;

h) permite a geração dos dados em tempo real através dos responsáveis pelas atividades.

Hamilton (2004a; 2004b), a partir de sua vasta experiência como consultor, também trata sobre as vantagens do ERP, as quais denominou de benefícios quantificáveis e efeitos intangíveis. Os benefícios quantificáveis do ERP, segundo Hamilton (2004a) são:

a) redução de estoques: a melhoria no planejamento e programação dos materiais promove tanto a redução de ativo quanto a redução de custos de manutenção de estoques;

b) reduções no custo do material: a melhoria nas práticas de aquisição leva à economia;

c) reduções no custo de mão-de-obra: a revisão dos processos e melhoria no modo de desempenhar as operações levam à maior eficiência;

d) vendas e serviços ao cliente melhorados: a melhor comunicação e coordenação entre as áreas de vendas e produção permite maior satisfação do cliente e melhor desempenho de vendas;

e) controles de contas a receber melhorados: otimização do gerenciamento de crédito e práticas de contas a receber permitem maior eficiência no recebimento e por 
conseqüência maior disponibilidade de caixa.

Os efeitos intangíveis do ERP, segundo Hamilton (2004b) são:

a) na Contabilidade: evita arquivos duplicados e duplicidade na entrada de dados; maior agilidade na apuração de custos; permite simulações de custos, as quais podem auxiliar em análises estratégicas; variações entre custo padrão e real obtidas auxiliam na análise de desempenho; a forma como os registros são armazenados permitem uma trilha de auditoria; as transações são registradas de forma detalhada permitindo esclarecimento fácil de quaisquer dúvidas; redução do tempo de fechamento contábil e elaborações dos demonstrativos; facilita a elaboração de demonstrativos customizados para atender à tomada de decisão;

b) no produto e design do processo: a estrutura do produto no banco de dados permite alterações no planejamento de produção com maior rapidez; disponibiliza ferramentas de análise para auxiliar na engenharia do produto;

c) na produção e gerenciamento de materiais: auxilia no planejamento da produção e no planejamento de materiais; facilita a negociação com fornecedores; otimiza o tempo de preparação das máquinas e também a seqüência das operações; permite a análise do impacto na produção provocado pelas mudanças ocorridas no que foi planejado;

d) nas vendas: agiliza o atendimento ao cliente com serviços mais rápidos; possibilita o $e$ commerce;

e) na área de sistemas de informação: a aquisição de um pacote traz diversas vantagens em relação ao desenvolvimento interno de um sistema, disponibilizando mais tempo para o gerenciamento das mudanças e suporte técnico aos funcionários.

Por outro lado, há também problemas relacionados ao ERP. Souza e Zwicker (1999, p. 69) mencionam alguns deles:
a) dependência do fornecedor;
b) a empresa não detém o conhecimento sobre o pacote;
c) tempo de aprendizagem de interfaces não desenvolvidas especificamente para a empresa;
d) necessidade de adequação do pacote à empresa;
e) necessidade de alterar processos empresariais; 
f) necessidade de consultoria para implementação;

g) alimenta a resistência a mudanças;

h) mudança cultural da visão departamental para a de processos;

i) maior complexidade de gestão da implementação;

j) custos e prazos de implementação maiores;

k) maior dificuldade na atualização do sistema pois exige acordo entre vários departamentos;

l) um módulo não disponível pode interromper o funcionamento dos demais;

m) mudança cultural da visão de "dono da informação" para a de "responsável pela informação";

n) se o sistema falhar toda a empresa pode parar.

Muitos desses itens não precisam necessariamente ser encarados como problemas, mas como desafios a serem enfrentados. Por exemplo, a necessidade de mudança cultural, se for bem orientada, é um desafio que poderá resultar em grandes vantagens para a empresa. Todavia, se não for dada a devida atenção a esse aspecto, certamente existirão problemas durante e depois da implementação do sistema.

Pode-se perceber, portanto, que a implementação de um ERP não é tarefa fácil. Kumar et al (2001, p. 2) entendem que a implementação do ERP demanda intensos esforços:

[...] reengenharia organizacional e de processos nos projetos de ERP, as implicações da empresa global, alto comprometimento de recursos, alto potencial de benefícios e riscos ao negócio associados com sistemas ERP fazem da sua implementação um complexo exercício de inovação e mudança organizacional, muito mais do que qualquer outro pacote de software ou tecnologia avançada de manufatura. ${ }^{3}$

${ }^{3}$ [...] organizational and process re-engineering in ERP projects, the enterprise-wide implications, high resource commitment, high potential business benefits and risks associated with ERP systems make their implementation a much more complex exercise in innovation and change management than any other software package or advance manufacturing technology. 
De fato, a complexidade do sistema requer uma implementação bem planejada, estruturada e executada. A literatura sobre o assunto aponta alguns passos a serem seguidos que geralmente são: analisar o sistema atual; desenvolver o novo sistema; definir processos, estrutura organizacional e procedimentos; customizar o software; treinar as pessoas; implementar o novo sistema; verificar se tudo ficou como previsto. Vale lembrar, todavia, que os fornecedores de ERP normalmente têm sua metodologia própria para a implementação, como é o caso da metodologia ASAP (Accelerated SAP) do fornecedor SAP.

No caso do ERP, talvez mais que em outros sistemas, cada um desses passos citados é de suma importância para o sucesso do projeto. Falhas em um deles podem comprometer o empreendimento que está sujeito a diversos riscos que devem ser observados e evitados.

\subsubsection{Riscos e fatores críticos de sucesso associados ao ERP}

\subsubsection{Riscos}

James Hall (2001) aponta alguns dos riscos relacionados à implementação do ERP:

\subsection{Estratégia de implementação - big bang versus em fases}

Na estratégia big bang, o ERP é colocado em funcionamento de uma só vez, ou seja, em um dia, a empresa termina o expediente utilizando os sistemas antigos e no outro dia começa o expediente utilizando o ERP.

Essa estratégia é a mais arriscada e provoca efeitos como: resistência por ser um sistema desconhecido com comentários como “o outro sistema era melhor” e paralisação das operações por falhas na entrada dos dados, na configuração do sistema ou outras de ordem técnica. Por ser um sistema integrado, dependendo do tipo de falha que ocorre, a empresa toda pode ficar paralisada até que se resolva o problema, o que pode durar horas ou dias.

Já a estratégia em fases evita situações dessa natureza, mas as vantagens do ERP só serão obtidas quando todo o sistema estiver implementado, o que pode demandar mais tempo e recursos. 
A decisão deve ser tomada avaliando as particularidades de cada empresa, mas a maioria das implementações apresentadas na literatura consultada é pela estratégia big bang.

\subsection{Resistência a mudanças (cultura organizacional)}

Quanto mais distante das práticas correntes for o sistema, mais complexa e demorada é a sua configuração e maiores resistências organizacionais podem surgir, pois é natural do ser humano experimentar um certo desconforto diante do novo, do incerto.

Algumas pessoas transformam esse desconforto em motivação para enfrentar o desafio e outras respondem com resistência às mudanças e adotam um comportamento que pode comprometer o sucesso do projeto, como já foi comentado anteriormente.

\subsection{Escolha errada do software de ERP}

A seleção do ERP é crucial - o sistema deve ajustar-se ao máximo às características da organização, visto que nenhum ERP sozinho resolve todos os problemas da empresa - e por isso, conhecer o software que se pretende comprar é essencial.

Pode ocorrer de os fornecedores apresentarem seu sistema como uma solução quase mágica para os problemas da organização. Outras vezes, a empresa atua em ramo com processos muito particulares e, nesses casos, o software pode não atender às expectativas criadas pela empresa, o que gera frustração e um sentimento de que o sistema não é inadequado, quando na verdade houve um equívoco quanto às suas reais possibilidades.

Para resolver os problemas que surgem, muitas empresas fazem adaptações no ERP ou desenvolvem softwares próprios com interface. Isso é um risco porque quanto mais se afasta do padrão do ERP mais difícil é a sua atualização. Além disso, o software perde suas características pois se não houver cautela, a empresa pode simplesmente adaptá-lo aos sistemas antigos e desperdiçar a oportunidade de adotar práticas mais novas e eficazes e, por conseqüência, perder muito do potencial do ERP. 


\subsection{Escolha errada dos consultores}

A empresa precisa recorrer a uma equipe de consultores para auxiliá-la na implementação do ERP. O que ocorre muitas vezes é que as empresas de consultoria não dispõem de pessoal altamente qualificado para atender a todos os clientes e por isso, muitas vezes, prometem profissionais altamente competentes e com vasta experiência (que estão presentes apenas nas entrevistas iniciais e apresentação do software para a compra), mas encaminham para a implementação profissionais com pouca experiência e sem a qualificação necessária.

\subsection{Alto custo e custos não previstos}

Podem ocorrer situações em que os custos são subestimados ou que durante a implementação aconteçam custos não previstos no projeto (por exemplo, referentes a treinamento, teste do sistema e conversão dos dados), aumentando consideravelmente o orçamento previsto e muitas vezes inviabilizando todo o projeto.

\subsection{Paralização das operações}

Dependendo da disposição das pessoas à mudança, ou seja, da cultura organizacional existente na empresa e de como esse fator foi trabalhado durante a implementação, pode ocorrer um período de adaptação ao sistema mais longo, e freqüentes interrupções nas operações da empresa podem comprometer suas atividades.

Para minimizar os riscos do projeto, é importante observar os fatores críticos de sucesso relacionados à implementação do ERP.

\subsubsection{Fatores críticos de sucesso}

Bancroft et al (1997) relacionam nove fatores, a saber:

\subsection{Compreender a cultura da empresa}

É necessário que a empresa esteja atenta quanto à capacidade de seus recursos humanos para executar as mudanças necessárias e quanto à disposição para fazer tais mudanças; 


\subsection{Iniciar a mudança dos processos de negócios antes da implementação}

Tendo em mente a estrutura do sistema a ser implementado, é preciso dedicar esforços em rever os processos de negócios que devem ser mudados e promover o redesenho dos mesmos, cuidando para não adotar nenhuma alteração que seja incompatível com o novo sistema. Todavia, outra alternativa já tem sido experimentada sem apresentar maiores problemas, que é rever os processos e promover o redesenho paralelamente à implementação.

\subsection{Manter uma comunicação constante}

Constantemente, é fundamental informar a todos na empresa sobre o andamento do projeto, sobre as mudanças necessárias e, principalmente, sobre o que se espera do sistema e das pessoas. Se os funcionários estiverem às escuras ficarão inseguros, criarão expectativas que podem atrapalhar o andamento do projeto e o sucesso pós-implementação.

\subsection{Garantir forte apoio dos executivos para o projeto}

É essencial que os altos executivos apóiem e se comprometam com o projeto, deixando evidente a todo momento essa posição, para garantir maior credibilidade e obter mais dedicação dos funcionários.

\subsection{Possuir um gerente de projeto qualificado}

É importante que o gerente de projeto esteja apto a desempenhar suas funções tendo em mente a interdependência entre os aspectos técnicos, de processos de negócios e de mudanças organizacionais. Todas as decisões a serem tomadas devem ser analisadas tendo em vista essa interdependência.

\subsection{Escolher uma equipe de projeto balanceada}

Os técnicos em sistemas são especialistas na configuração do software e na manutenção de equipamentos, mas os experts em cada área de negócio são seus próprios funcionários, já que eles vivem o dia-a-dia das atividades. Para formar uma equipe adequada, é necessário mesclar pessoas qualificadas de cada área de negócio e técnicos em sistemas. 


\subsection{Escolher uma boa metodologia de projeto}

Devido à complexidade do sistema, é necessário adotar uma metodologia que permita sempre verificar o progresso da implementação em relação aos objetivos iniciais.

\subsection{Treinar os usuários}

Como mudanças nos processos são necessárias, é imprescindível que os usuários do sistema sejam treinados para executar as operações nesse novo ambiente. Novos conhecimentos e habilidades são requisitados e a empresa deve estar atenta à qualificação de seus funcionários.

\subsection{Comprometer-se com a mudança}

É inevitável que imprevistos aconteçam quando se está implementando um sistema do porte do ERP. Por isso, as pessoas envolvidas no projeto devem estar comprometidas e prontas para quando os problemas surgirem.

Se a empresa empregar esforços em obter sucesso em cada um desses fatores, certamente terá menos propensão aos riscos e aos problemas citados acima, e assim poderá aproveitar melhor as vantagens oferecidas pelo ERP.

Por outro lado, não é somente durante a implementação que os cuidados devem ser tomados. Quando o sistema entra em funcionamento começa uma nova etapa, a qual corresponderá à medida do sucesso de todo o projeto. Segundo Hammer (1999, p. 24), “O go live - momento em que o sistema ERP entra em operação em uma empresa - ao contrário do que muita gente pensa, é o início de tudo, não o fim. É nele que a prática dos processos se inicia.”

Portanto, quando a empresa está estudando a possibilidade de aquisição de um ERP é necessário conhecer as vantagens que podem ser obtidas, os problemas que podem surgir, os riscos que devem ser enfrentados e como evitá-los.

É importante ter sempre em mente que a simples presença de uma tecnologia avançada como o ERP não garante o sucesso esperado. Como comentado anteriormente, o ERP é muito 
complexo e para ter sucesso precisa se apoiar na mudança organizacional. Esse tema será discutido mais adiante. Na seqüência, é apresentado o ERP R/3 da empresa SAP.

\subsubsection{SAP}

Neste trabalho, optou-se por desenvolver os estudos de casos em empresas que implementaram o software R/3 da SAP, visto que esta empresa é líder no mercado de ERP, foi uma das primeiras a oferecer esse tipo de sistema, inclusive influenciando a estrutura dos produtos de seus concorrentes, e também conta com grande experiência em implementações. Além das questões relacionadas diretamente ao $\mathrm{R} / 3$, a opção por empresas com o mesmo software também está relacionada à metodologia da pesquisa, no que se refere à garantia de comparabilidade dos dados entre os casos, na análise dos resultados.A configuração básica do R/3 pode ser vista na Figura 1:

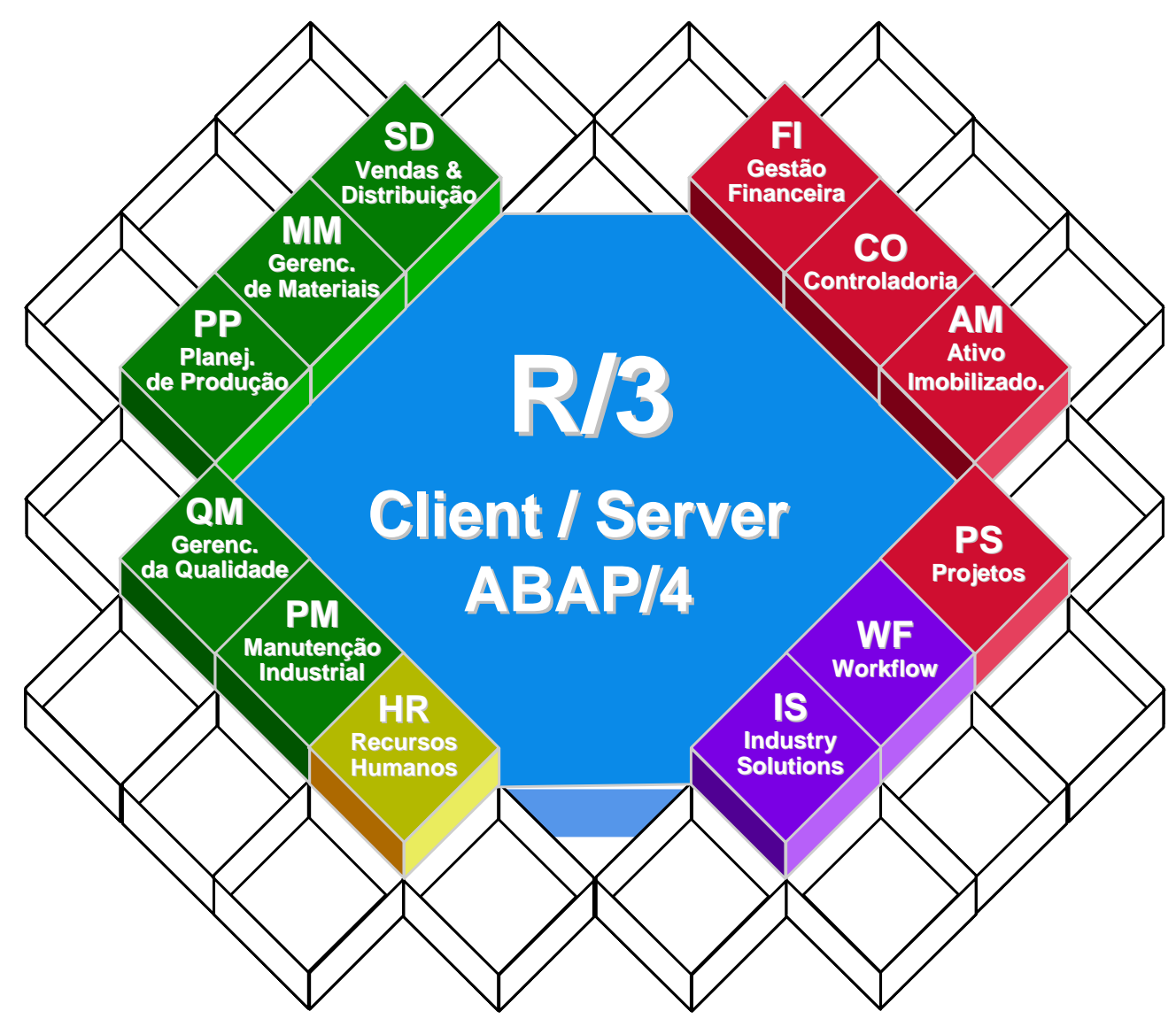

Figura 1 - Configuração Básica do R/3

Fonte: KALE, 2000, p. 85 
Tendo em vista que este trabalho teve como foco a Contabilidade, foram detalhados apenas os módulos desse segmento, ou seja, o de Gestão Financeira (FI) e o de Controladoria (CO). O módulo Ativo Fixo (AM), na literatura utilizada para a descrição abaixo (BLAIN, 1998; KALE, 2000), está incluído no FI.

\subsubsection{Gestão financeira (FI)}

O módulo Gestão Financeira (Financial Accounting) é considerado a estrutura principal do sistema. Segundo Hall (2001, p. 574), este módulo é a espinha dorsal do R/3 e relaciona e integra os outros módulos do sistema. Ele permite a execução da chamada Contabilidade Financeira.

Os componentes ou submódulos do FI são, de acordo com Blain (1998) e Kale (2000):

a) Contabilidade Geral (general ledger - GL): recebe dados de todas as transações que acontecem na organização e mantém as contas que servem de base para a elaboração dos relatórios contábeis. Como menciona Blain (1998, p. 26), por conveniência, o general ledger é auxiliado por diversos subrazões, tais como os de contas a receber e contas a pagar, e possui integração com estes subrazões.

b) Contas a Receber (accounts receivable)/Contas a Pagar (accounts payable): são razões auxiliares do general ledger, uma extensão deste, utilizados para manter separadamente as contas dos diversos credores e devedores da empresa. Diferentemente dos razões especiais (special purpose ledger) são parte integrante do general ledger.

c) Razões Especiais (special purpose ledgers - SPL): permitem a criação de relatórios especiais que não são possíveis de obter através do submódulo Contabilidade Geral e dos submódulos do controlling, se este último não estiver totalmente disponível. Os relatórios são emitidos a partir de qualquer combinação de dados solicitada, desde que os dados estejam disponíveis (Ibid., p. 9). Caso todo o módulo Controlling esteja disponível não é necessário utilizar os razões especiais, pois as funcionalidades que este oferece já estão incluídas no Controlling. (Ibid., p. 38).

d) Consolidação (legal consolidation - LC): faz a consolidação dos demonstrativos contábeis de duas ou mais empresas, atendendo às exigências legais. Esse processo pode incluir reclassificação, reavaliação e a consolidação propriamente dita. 
e) Ativo fixo (asset management - AM): gerencia o ativo fixo, ou seja, controla as aquisições, baixas, transferências, reavaliações, ativos em construção, entre outros. Calcula a depreciação por diversas metodologias.

\subsubsection{Controladoria (CO)}

Este módulo permite a execução de algumas atividades da Contabilidade Gerencial, no que se refere a controle de custos e de lucratividade. É totalmente integrado com o módulo FI e ambos são constantemente reconciliados ao nível de contas individuais do general ledger. Os componentes ou submódulos do CO são, de acordo com Blain (1998) e Kale (2000):

a) Contabilidade por Centro de Custo (cost center accounting-CCA): tem por função criar e manter os dados mestres dos centros de custos, permitindo a execução da Contabilidade por centro de custo.

b) Contabilidade por ABC (activity-based cost accounting - ABC): permite planejar, monitorar e fixar as atividades dos centros de custos, definindo os direcionadores de custos. Otimiza os processos nos centros de custos.

c) Contabilidade de Custo por Produto (product cost accounting - PC): permite a apuração do custo por produto. Também permite o controle dos custos reais em relação aos custos pré-definidos. Utiliza todos os métodos de custeio praticados.

d) Contabilidade por Ordem e Projeto (order and project accounting - OPA): controla os custos dos projetos e ordens internas. Permite “[...] planejar, monitorar e fixar as atividades, serviços e processos decorrentes dos projetos e ordens internas."4 (BLAIN, 1998, p. 253). Os custos podem ser estabelecidos com riqueza de detalhes e não de forma agregada, o que possibilita o controle atendendo aos diversos critérios desejados.

e) Análise de Rentabilidade (profitability analysis - PA): permite a análise de lucratividade das unidades de lucros definidas, bem como da empresa como um todo. Também permite a análise do custo das vendas. Proporciona um leque de possibilidades para realizar a análise, ficando a cargo do usuário escolher o critério que atende às suas necessidades. Atua em conjunto com o PCA.

\footnotetext{
4 "[...] planning, monitoring, and settling the activities, services, and processes that take place as the result of internal orders and projects.”
} 
f) Contabilidade por Centro de Lucro (profit center accounting - PCA): executa o controle da rentabilidade dos centros de lucros.

Considera-se que o R/3 é um pacote de software que a empresa adquire e deve configurá-lo (customização) para, na medida do possível, atender às particularidades do seu negócio. Pode ocorrer de nem todos os módulos oferecidos serem utilizados, caso, na aquisição do software, a empresa fizer a opção por não customizar alguns módulos. Ainda pode ser que, mesmo estando customizado, a empresa não os utilize devido à falta de pessoal qualificado, problemas com a customização ou com os processos da empresa, entre outros.

Cada implementação de ERP, e não é diferente com o R/3, tem suas particularidades e depende de um grande esforço para rever os processos e as questões organizacionais de uma forma geral e, se necessário, promover as mudanças, o que normalmente acontece para o êxito da adoção do sistema.

Este trabalho teve interesse em verificar se ocorreram alterações na área de Contabilidade com a implementação do ERP e, para subsidiar a análise dos dados da pesquisa empírica, são apresentadas algumas discussões sobre mudança organizacional.

\subsection{Mudança Organizacional}

\subsubsection{Mudança organizacional e tecnologia da informação}

Antes de explorar detalhes sobre as estruturas das organizações, é necessário entender melhor a própria organização. Dentro desse contexto, adotou-se a seguinte definição de organização:

Uma organização é uma entidade social conscientemente coordenada, com uma fronteira relativamente identificável, que funciona em uma base relativamente contínua para alcançar uma meta comum ou um conjunto de metas. ${ }^{5}$ (ROBBINS, 1990, p. 4).

\footnotetext{
${ }^{5}$ An organization is a consciously coordinated social entity, with a relatively identifiable boundary, that functions on a relatively continuous basis to achieve a common goal or set of goals.
} 
A expressão conscientemente coordenada implica em gerenciamento e as palavras entidade social significam que as várias unidades da organização são compostas por pessoas ou por grupos de pessoas que interagem entre si, seguindo determinados padrões de interação. É, portanto, necessário, que haja um constante gerenciamento desses padrões de interação a fim de que haja uma certa harmonia que permita a execução das diversas atividades existentes na empresa.

Ter uma fronteira relativamente identificável significa que deve ser possível estabelecer os limites de uma organização, separando as pessoas que fazem parte dela daquelas que não fazem parte.

Finalmente, para alcançar suas metas, a organização utiliza a divisão de trabalho e a hierarquia de autoridade. As atividades são divididas em tarefas e distribuídas entre as pessoas para serem melhor executadas. Também é preciso que haja uma escala de autoridade para que as atividades sejam adequadamente coordenadas.

Uma abordagem válida para iniciar um estudo sobre organizações é tratá-las como um sistema. Existem muitas definições de sistema na literatura, mas é possível observar que todas têm alguns aspectos em comum. Geralmente, em tais definições são citadas: a presença de mais de um elemento, a relação de interação entre esses elementos e a existência de um ou mais objetivos em comum.

Dessa forma, é possível entender sistemas tendo como base a definição proposta por Churchman (1972, p. 50) que, sendo simples e sucinta, expressa adequadamente o conceito: “[...] um sistema é um conjunto de partes coordenadas para realizar um conjunto de finalidades."

No caso da organização, as partes ou elementos podem ser identificados como sendo seus recursos materiais e financeiros, as pessoas, as tarefas, as informações, as normas, entre outros. Todos esses elementos mantêm entre si uma relação de interdependência e, como resultado dessa interação, os objetivos da organização são alcançados. 
A organização pode, portanto, ser considerada como uma série de componentes - a tarefa, os indivíduos, a organização formal e a organização informal. Em qualquer sistema, porém, a questão crítica não é quais são os componentes, mas qual a natureza da sua interação e como as relações entre eles afetam a maneira pela qual se combinam para dar o produto. (NADLER et al, 1994, p. 39).

Nesse sentido, quando se fala em mudança organizacional, é preciso observar o todo, pois, provavelmente, quando um dos componentes da organização é alterado, ocorrerão mudanças nos demais, sendo algumas mais substanciais e outras mais amenas.

Autores como Galliers (1998) e Walton (1993) adotam essa visão sistêmica ao tratar de mudança organizacional. A Figura 2, extraída de Galliers (1998), o qual baseou-se no “diamante de Leavitt”, demonstra a interação dos elementos da organização:

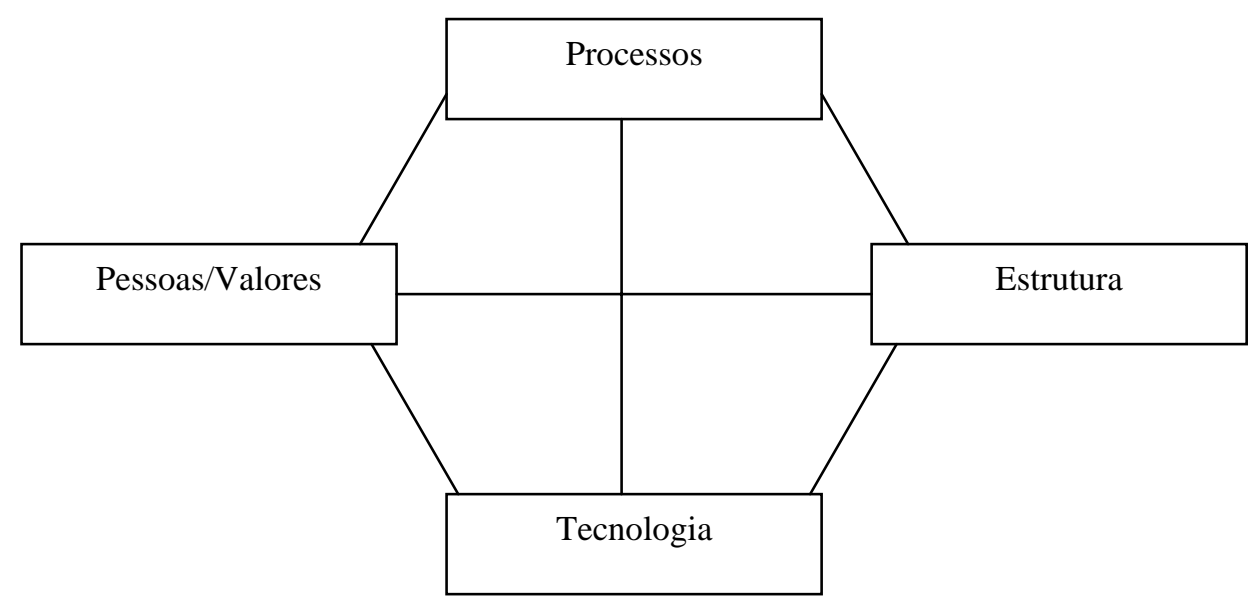

Figura 2 - Interação dos Elementos da Organização

Fonte: GALLIERS, 1998, p. 232

Como demonstrado no quadro acima, a organização é vista como o conjunto de processos, estrutura, tecnologia, pessoas e valores. Esses elementos interagem e sempre que for decidido que haverá mudanças em um deles, deve, ainda na fase de planejamento, ser observado o impacto nos demais, sob pena de fracasso do projeto.

A respeito da variável tecnologia, tratando especificamente de tecnologia de informação, por vezes, a alteração apresenta-se como uma oportunidade para repensar toda a organização e promover a mudança organizacional. Sobre isso Turner (1998, p. 246) comenta: 
[...] designers de sistema têm sempre usado a implementação de novos sistemas como oportunidade de fazer uma substancial mudança organizacional e operacional. Freqüentemente os fluxos de informação e procedimentos são completamente repensados e cargos reconstituídos antes de um sistema de informação ser implementado. ${ }^{6}$

Todavia, muitas vezes ocorre o engano em pensar que a simples presença da nova TI promoverá todas as demais mudanças imprescindíveis. Não é um processo simples e automático. É preciso um planejamento para visualizar os impactos, promover os ajustes e reorganizar o sistema de trabalho. Além dos ajustes técnicos, é preciso conquistar o apoio das pessoas que fazem parte da organização, pois, muitas vezes, estas se sentem ameaçadas, com medo de perder o emprego, serem substituídas pelas máquinas, entre outras inseguranças. Para se protegerem, conscientes ou não, acabam por aceitar a mudança, mas sem o comprometimento necessário, o que, a longo prazo, pode levar o projeto a ser abandonado ou implementado com deficiências.

A influência da tecnologia na mudança organizacional é um assunto que desperta muito interesse, mas requer pesquisas que demonstrem como essa relação acontece. “Apesar de ser geralmente conhecido que tecnologia da informação (TI) desempenha um importante papel na mudança organizacional, há pouca concordância em que tipo de papel é, as tecnologias chaves que poderiam ser utilizadas, e como elas podem ser aplicadas.”7 (Ibid., p. 245).

Para Winfield (1991, p. 105) “[...] enquanto nem todos os trabalhos estão sendo radicalmente modificados pela tecnologia de informação, restam poucos que não são influenciados de algum modo.”8 Já Walton (1993, p. 31) afirma que:

As formas de TI avançadas têm conseqüências organizacionais mais amplas e profundas do que as anteriores. Quanto maior a funcionalidade de um sistema de TI, maiores níveis de aprendizado e ajustamento são necessários para sua utilização, indo desde as habilidades dos operadores por meio dos procedimentos e estrutura organizacionais até os aspectos culturais.

\footnotetext{
${ }^{6}$ (...) system designers have always used times of new system implementations as opportunities to make substantial organizational and operational change. Often information flows and procedures are completely rethought and jobs reconstituted before an information system is implemented.

${ }^{7}$ Whilst it is generally acknowledged that information technology (IT) plays an important role in organization change, there is little agreement on what that role is, the key technologies that could be used, and how they might be applied.

8 "[...] whilst not all jobs are being radically transformed by information technology, there remain few that are unaffected in some way."
} 
Para subsidiar adequadamente a análise dos dados obtidos na pesquisa de campo, foi necessário, além dos tópicos já abordados anteriormente, rever os pontos principais referentes à estrutura organizacional, ao design (desenho) organizacional e à estrutura de cargos.

\subsubsection{Estrutura das organizações}

A organização se vale de uma estrutura que define os padrões de interação a serem seguidos e permite dividir as atividades, alocar as tarefas às pessoas, acompanhar para que tais tarefas sejam desempenhadas corretamente e transmitir as informações para os que delas necessitam. Esse arcabouço é chamado de estrutura organizacional.

Para Mintzberg (2003, p. 12), “[...] a estrutura de uma organização pode ser definida simplesmente como a soma total das maneiras pelas quais o trabalho é dividido em tarefas distintas e, depois, como a coordenação é realizada entre essas tarefas.”

Na visão de Chandler (1962, p. 14):

Estrutura pode ser definida como o desenho da organização, através do qual o negócio é administrado. Este desenho, seja formalmente ou informalmente definido, tem dois aspectos. Isto inclui, primeiro, as linhas de autoridade e comunicação entre os diferentes funcionários e unidades administrativas e, segundo, a informação e dados que fluem através dessas linhas de comunicação e autoridade. ${ }^{9}$

Nessas duas definições, foram citados os aspectos essenciais para entender a estrutura organizacional: a divisão das atividades e a coordenação das mesmas; a existência de muitas maneiras para realizar a divisão e a coordenação das tarefas; as linhas de autoridade; as linhas de comunicação/fluxo de dados e informação e a existência de uma estrutura formal e outra informal.

Além de entender o que é estrutura organizacional, também é importante compreender para que ela serve. Segundo Richard Hall (2004, p. 47) tais estruturas executam três funções básicas:

\footnotetext{
${ }^{9}$ Structure can be defined as the design of organization through which the enterprise is administered. This design, whether formally or informally defined, has two aspects. It includes, first, the lines of authority and communication between the different administrative offices and officers and, second, the information and data that flow through these lines of communication and authority.
} 
Primeiro e mais importante, as estruturas têm por finalidade produzir resultados organizacionais e atingir metas organizacionais - em outras palavras, ser eficazes. Segundo, as estruturas são criadas para minimizar ou, ao menos, regular a influência das variações individuais na organização [...] terceiro, as estruturas são os cenários nos quais o poder é exercido (elas também fixam ou determinam que posições possuem o maior poder), as decisões são tomadas (o fluxo de informações para uma decisão é, em grande parte, determinado pela estrutura) e as atividades são realizadas (a estrutura é o espaço para as ações organizacionais).

A organização enfrenta o desafio de estabelecer uma estrutura organizacional que permita uma adequada coordenação e controle das diversas atividades e dos anseios individuais das pessoas, permitindo uma boa comunicação e, por fim, promovendo a eficiência.

Segundo a teoria proposta por Robbins (1990), apresentada na Figura 3, a estrutura organizacional é formada por três componentes que são: complexidade, formalização e centralização. Além destes, o autor também faz referência a cinco variáveis que são consideradas como causas da estrutura, chamadas de determinantes: estratégia, tamanho, tecnologia, ambiente e poder-controle.

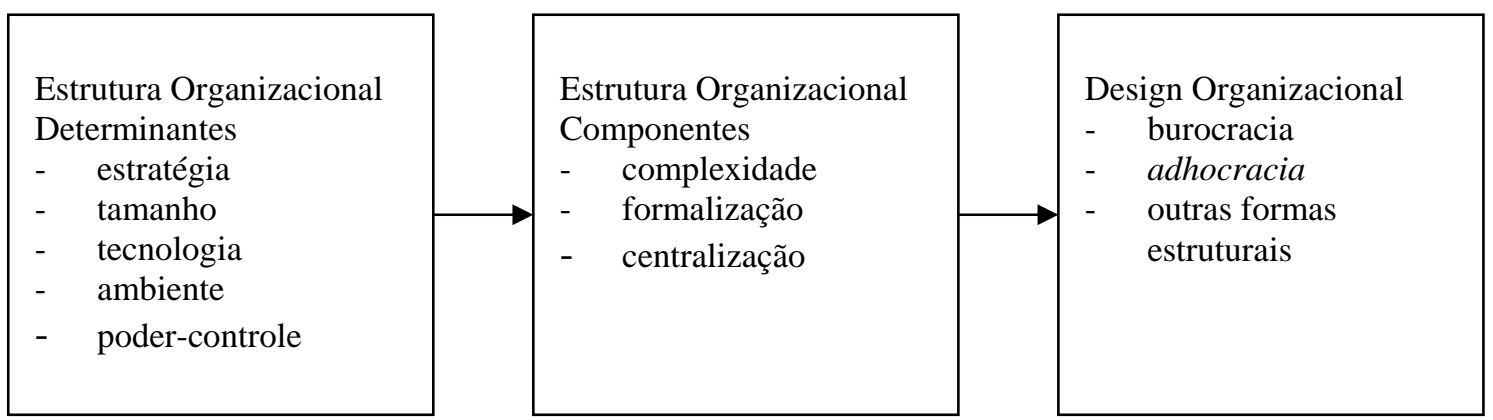

Figura 3 - Modelo de Teoria Organizacional

Fonte: Adaptado de ROBBINS, 1990, p. 26

Outros autores como Gibson et al. (1981), Richard Hall (2004), Mintzberg (2003), Vasconcelos e Hemsley (2002) apresentam propostas utilizando termos diferentes mas que, em sua maioria, são abordados na classificação escolhida, de forma agregada.

Neste trabalho, optou-se pela adoção da teoria proposta por Robbins (1990) por ser uma obra muito respeitada e também bastante didática, permitindo que o leitor que não possui muita experiência com o assunto possa ter a compreensão necessária para subsidiar o entendimento dos resultados da análise dos casos, os quais são apresentados posteriormente. Além disso, 
sua proposta está em consonância com a visão de outros autores, conforme comentado acima, o que contribui para a validade da pesquisa.

\subsubsection{Componentes}

Em linhas gerais, a complexidade relaciona-se com a extensão da diferenciação dentro da organização (o que inclui grau de especialização ou divisão do trabalho, número de níveis de hierarquia e dispersão geográfica das unidades); a formalização refere-se ao grau de padronização que uma organização utiliza para dirigir o comportamento dos empregados; e a centralização considera onde está direcionada a autoridade para a tomada de decisão.

Uma análise mais aprofundada destes componentes evidencia que o primeiro deles, a complexidade, é composto por três elementos: diferenciação horizontal, diferenciação vertical e diferenciação espacial.

Na visão de Robbins (1990, p. 84), a diferenciação horizontal está relacionada à necessidade de divisão das tarefas (especialização) e ao reagrupamento dessas tarefas, segundo determinados critérios (departamentalização).

A divisão das tarefas, que o autor chama de especialização funcional, ocorre quando as atividades são divididas em tarefas mais simples e repetitivas e para executá-las é necessário um conhecimento bastante específico e restrito. Nesse caso, a especialização está relacionada às tarefas, como o próprio nome sugere. Também é importante considerar a especialização social, que ocorre quando as pessoas é que são especializadas. Nessa abordagem, para executar as tarefas é preciso conhecimento profissional mais abrangente que no caso anterior. Os engenheiros, auditores, advogados são exemplos de profissionais que apresentam a especialização social.

Richard Hall (2004, p. 51) descreve a diferenciação horizontal e afirma que existem basicamente duas maneiras para proceder a subdivisão das tarefas de uma organização:

A primeira maneira pela qual as tarefas podem ser subdivididas consiste em atribuir a especialistas altamente treinados uma faixa abrangente de atividades para desempenhar; a segunda consiste em subdividir detalhadamente as tarefas, para que pessoas não especializadas possam executá-las. 
A especialização tem sido uma questão fundamental na definição das estruturas, pois exige a opção entre modelos com cargos mais amplos, que abrangem um número maior de tarefas, as quais implicam habilidades e conhecimentos mais variados dos ocupantes desses cargos, e modelos com cargos mais restritos, que abrangem menos tarefas, as quais são altamente especializadas e exigem habilidades e conhecimentos mais específicos.

Outro conceito que está relacionado à diferenciação horizontal é a departamentalização. Após divididas, as atividades precisam ser combinadas em grupos, obedecendo determinados critérios. Esse processo é chamado departamentalização e os critérios geralmente adotados são: função, produtos ou serviços, clientes, área geográfica e processo. Robbins (1990, p. 86) comenta que em grandes organizações são encontrados todos esses tipos juntos numa mesma estrutura. Segundo Gibson et al. (1981, p. 249), “[...] há um desejo crescente de experimentar critérios múltiplos ou mistos, dentro da mesma organização.”

A diferenciação vertical, segundo elemento da complexidade, está relacionada aos níveis de hierarquia e determina a profundidade de uma estrutura. Estruturas mais achatadas são aquelas com menos níveis hierárquicos e por conseqüência mais pessoas subordinadas ao administrador. Estruturas mais altas são aquelas com mais níveis hierárquicos e menos pessoas subordinadas ao administrador. Robbins (1990, p. 87) chama a atenção para o fato de que existe uma dependência entre a diferenciação horizontal e vertical e comenta que "A diferenciação vertical pode ser melhor entendida como resposta ao aumento na diferenciação horizontal."10

Mintzberg (2003, p. 39) tem o mesmo entendimento e detalha:

\footnotetext{
Em particular, quando o trabalho é altamente especializado na dimensão horizontal, a perspectiva do trabalhador é limitada, o que dificulta relacionar seu trabalho com os dos outros. Assim, o controle do trabalho é, freqüentemente, transferido a um gerente com a visão abrangente necessária para coordenar o trabalho por supervisão direta ou a um analista que possa fazê-lo por padronização. Assim, os trabalhos devem, com freqüência, ser verticalmente especializados em razão de serem horizontalmente especializados.
}

Nesse sentido, quando as organizações promovem uma análise da estrutura com intenção de executar uma redução dos níveis hierárquicos, aproximando o nível operacional do nível estratégico, é importante observar que as decisões referentes à dimensão vertical 
(diferenciação vertical) certamente vão afetar a dimensão horizontal (diferenciação horizontal) no que tange à coordenação e controle das atividades. Isso porque a visão restrita das pessoas que executam as tarefas que são bastante limitadas pode levar à falta de percepção da contribuição da sua tarefa para a empresa como um todo, o que pode gerar diversas situações que levam à ineficiência.

A diferenciação espacial, terceiro elemento da complexidade, está relacionada à localização geográfica das unidades da organização. As organizações podem ser divididas em unidades e estas estarem localizadas numa mesma área geográfica ou em áreas diferentes. Se duas empresas têm suas unidades organizadas da mesma forma quanto à diferenciação vertical e horizontal, mas numa delas as unidades estão localizadas em cidades diferentes, enquanto na outra as unidades estão localizadas numa mesma área geográfica, aquela cujas unidades estão dispersas é mais complexa, pois há maior dificuldade para coordenação e controle das atividades. Nesse sentido, Robbins (1990, p. 91) afirma que “[...] a separação física em si aumentaria a complexidade." 11

Como a complexidade diz respeito à diferenciação existente na estrutura da organização, a relação que pode ser estabelecida é que quanto maior for a especialização das tarefas e a divisão do trabalho, quanto maior for o número de níveis hierárquicos e quanto mais dispersa geograficamente estiver a organização, mais complexa ela será. Isso porque a organização é composta de partes e essas partes precisam se comunicar, precisam de coordenação e de controle. Em outras palavras, quanto mais alta for a complexidade da estrutura organizacional, mais problemas os gestores terão para garantir boa comunicação entre as pessoas das diferentes partes da organização, mais difícil será a coordenação das atividades e mais difícil será o controle da execução das atividades.

A visão de Richard Hall (2004, p. 49) corrobora esse entendimento: “Organizações complexas contêm muitas subpartes que exigem coordenação e controle e, quanto mais complexa uma organização, mais difícil atingir a coordenação e o controle.”

O segundo componente, a formalização, refere-se às normas, procedimentos, autoridade para tomada de decisões e fluxo de informações previstos em manuais ou outros documentos

\footnotetext{
10 "Vertical differentiation may be understood best as a response to an increase in horizontal differentiation."
} 
formalmente preparados e disseminados pela organização, os quais buscam padronizar o comportamento das pessoas e determinar regras para as atividades serem realizadas. Para Robbins (1990, p. 93) “Formalização se refere ao grau no qual o trabalho dentro da organização é padronizado.”12

A formalização é importante, principalmente, porque reduz a variação do comportamento das pessoas, no momento em que padroniza esse comportamento. Para Mintzberg (2003, p. 46), “As organizações formalizam o comportamento para reduzir sua variabilidade e, finalmente, para prevê-lo e controlá-lo.” Dessa forma, torna-se mais fácil coordenar as atividades.

Muitas vezes, a organização opera de maneira diferente daquela estabelecida nos manuais, ou seja, a autoridade, a liderança, o fluxo de informações e outros fatores são diferentes do previsto nas regras, gerando a estrutura informal. É de grande importância considerar a existência desta, pois ela pode ser mais forte e determinante do comportamento das pessoas que a própria estrutura formal.

Robbins (1990, p. 94) traz à tona uma discussão sobre o que observar ao avaliar a formalização: apenas os documentos escritos ou também a percepção das pessoas? Sua posição é que, para refletir a realidade da vida organizacional, ambos deveriam ser considerados, pois muitas vezes algumas regras e padrões não estão escritos, todavia são reforçados e passam a fazer parte da estrutura formal, pois têm o aval das pessoas responsáveis pela determinação das regras.

Por fim, outro aspecto de relevância a observar é que quanto maior a profissionalização de um trabalho (especialização social), menores as possibilidades de ele ser altamente padronizado. Por exemplo, um engenheiro ou um auditor está menos sujeito a ter que atender a uma rotina estabelecida pela organização do que um operador de máquinas. As atividades profissionais têm sua padronização determinada pelas exigências da própria profissão, sendo tais padrões absorvidos no período de formação, durante a preparação para o mercado de trabalho.

Além disso, conforme comenta Richard Hall (2004, p. 69) a profissionalização e formalização são incompatíveis, pois “Quanto mais profissionalizada a equipe de trabalho, maior a

11 “ $[. .$.$] the physical separation itself would increase complexity.”$ 
possibilidade de a formalização conduzir ao conflito e à alienação.”

Uma análise que pode ser estabelecida, tendo em vista a literatura consultada, é que o maior grau de formalização da estrutura organizacional deveria facilitar a coordenação das atividades e o controle. Além disso, geralmente, quanto mais níveis hierárquicos e quanto maior for a especialização advinda da divisão do trabalho (especialização funcional), maior será o grau de formalização presente nas estruturas, pois trata-se de tarefas repetitivas, rotineiras, com um padrão de procedimentos detalhado a ser seguido. Por outro lado, quando ocorre a especialização social há uma tendência à baixa formalização, visto que o padrão de procedimentos a ser seguido é inerente às profissões e pouco depende das particularidades da empresa.

O terceiro componente, a centralização, refere-se ao grau de autoridade para a tomada de decisões delegado aos diferentes níveis da organização. Robbins (1990, p. 114) define centralização como “[...] o grau no qual a autoridade formal para fazer escolhas conscientes é concentrada em uma pessoa, unidade ou nível (geralmente altos na organização), dessa forma permitindo aos empregados (geralmente dos níveis inferiores da organização) o mínimo de input em suas tarefas.”13

Assim, quanto mais dispersa for a autoridade para a tomada de decisão mais descentralizada será a estrutura. Por outro lado, quanto maior for a concentração de autoridade para a tomada de decisão, mais centralizada será a estrutura. É necessário salientar que centralização e descentralização são os extremos de um continuum, ou seja, as organizações tendem a ser centralizadas ou descentralizadas, mas apresentam ambas as características.

Uma estrutura mais complexa normalmente está relacionada com maior descentralização, o que em tese facilita a coordenação das atividades, o controle e a comunicação. Na literatura consultada (ROBBINS, 1990; HALL, 2004; MINTZBERG, 2003; GIBSON et al., 1981), não foi encontrada relação clara entre formalização e centralização. As pesquisas publicadas sobre este assunto na referida literatura demonstram que, aparentemente, as atividades

\footnotetext{
12 "Formalization refers to the degree to which jobs within the organization are standardized."

13 " [...] the degree to which the formal authority to make discretionary choices is concentrated in an individual, unit, or level (usually high in the organization), thus permitting employees (usually low in the organization) minimum input into their work."
} 
desempenhadas por profissionais que requerem mais habilidades são melhor desempenhadas com baixa formalização e maior descentralização. Já as atividades desempenhadas por outros empregados, sem a exigência de formação profissionalizante, são bem executadas quando a estrutura apresenta alta formalização e alta centralização. Também não há evidências sobre a relação entre os elementos de coordenação, comunicação e controle e as estruturas centralizadas ou descentralizadas.

\title{
2.2.2.2 Determinantes
}

Tomando-se por base os elementos que compõem a estrutura organizacional e o relacionamento entre eles, uma questão surge naturalmente para o gestor ou quem quer que esteja interessado em definir ou analisar uma estrutura organizacional: Qual a melhor combinação entre esses elementos? Ou perguntado de outra forma: O que determina a estrutura organizacional?

Robbins (1990) analisou diversos estudos desenvolvidos por outros pesquisadores sobre o assunto e identificou cinco variáveis como as mais pesquisadas e as que mais se destacaram como prováveis determinantes da estrutura: estratégia, tamanho, tecnologia, ambiente e poder/controle. Segue um breve comentário sobre cada uma.

A primeira delas, estratégia, inclui as metas de longo prazo e um curso de ação que fornece os meios para alcançá-las. Pesquisas como a de Chandler (1962) e outras analisadas por Robbins (1990) como a de Miles e Snow (1978), Porter (1980; 1985) e Miller (1987) sugerem que a estrutura segue a estratégia. Segundo Chandler (1962, p. 13):

\begin{abstract}
A tese que diferentes formas organizacionais resultam de diferentes tipos de ampliação das atividades pode ser determinada mais precisamente se o planejamento e a execução de tal expansão são considerados uma estratégia, e se a organização criou para administrar estes recursos e atividades ampliadas, uma estrutura. ${ }^{14}$
\end{abstract}

As comprovações desses pesquisadores estão condicionadas a algumas restrições como tamanho da organização, estágio do ciclo de vida, ramo de negócios das empresas

\footnotetext{
${ }^{14}$ The thesis that different organizational forms result from different types of growth can be started more precisely if the planning and carrying out of such growth is considered a strategy, and the organization devised to administer these enlarged activities and resources, a structure.
} 
pesquisadas. Todavia, apesar de identificarem que existe relacionamento entre estratégia e estrutura, as pesquisas não apresentam evidências suficientes para comprovar que a estratégia é a principal determinante da estrutura.

A segunda variável, o tamanho da organização, refere-se ao número total de empregados. Robbins (1990) analisou diversas pesquisas (BLAU, 1971; ASTON GROUP, 1969; MEYER, 1972; ARGYRIS, 1972; ALDRICH, 1972; HALL, 1967) que abordaram tamanho e estrutura organizacional e comenta sobre algumas evidências que relacionam essas duas variáveis, mais especificamente no que tange à diferenciação vertical, à formalização e à descentralização. O autor conclui que, embora em alguns casos tenha sido verificada certa influência, o tamanho não é capaz de explicar a estrutura.

As evidências indicam que, além do tamanho, outras variáveis devem ser consideradas conjuntamente para se compreender determinada estrutura. Richard Hall (2004) compartilha a opinião de Robbins. É importante salientar que todas as pesquisas analisadas pelo autor foram desenvolvidas em grandes e médias empresas e, portanto, é necessário cuidado ao estender as conclusões para pequenas empresas.

A terceira variável, tecnologia, na abordagem de Robbins (1990), diz respeito aos processos e métodos que transformam inputs em outputs na organização. O termo inclui todo tipo de processo input/processamento/output, inclusive a tecnologia de informação, para todas as empresas, seja do segmento indústria, comércio e serviços, independente do ramo de atuação.

O autor analisou importantes pesquisas como as de Woodward (1965), Perrow (1967) e Thompson (1967), as quais procuraram evidências sobre o relacionamento entre tecnologia e estrutura organizacional. Tais pesquisas se concentraram nas áreas de tecnologia de produção e tecnologia do conhecimento.

Esses estudos evidenciam que a tecnologia mais simples, que atende as tarefas rotinizadas, está relacionada com baixa complexidade e alta formalização. A relação entre tecnologia e centralização é muito inconsistente, pois é muito dependente do grau de formalização. Isso significa que embora as organizações descentralizadas tendem a utilizar tecnologia mais sofisticada para atender a necessidade de tomada de decisão nas pontas, em empresas com alto grau de formalização, mesmo com autoridade descentralizada, a tecnologia de rotina, 
mais simples, foi encontrada.

Robbins (1990, p. 201) conclui que tecnologia e estrutura estão relacionadas, mas não é possível considerar tecnologia como a principal determinante da estrutura. As pesquisas citadas acima demonstraram que a relação é mais evidente em pesquisas com foco nas tarefas (e não em nível de organização), em pequenas empresas e quando o “arranjo estrutural” está relacionado com a operação principal da empresa.

Em consonância com as conclusões comentadas acima, Richard Hall (2004, p. 87) salienta que os pesquisadores que estudaram amplamente este tema na década de 70 perceberam que melhores resultados eram obtidos se tamanho e tecnologia fossem considerados juntos, como variáveis determinantes da estrutura.

A quarta variável, o ambiente, diz respeito às forças ou instituições que de alguma forma afetam a organização, mas que não podem ser controladas por ela. O relacionamento estabelecido é que as organizações estão expostas a diversas incertezas ambientais e que o design estrutural pode ser considerado a principal ferramenta que os gerentes dispõem para eliminar ou minimizar o impacto da incerteza ambiental.

As pesquisas desenvolvidas por Burns e Stalker (1961), Emery e Trist (1965), Lawrence e Lorsch (1967), analisadas por Robbins (1990) demonstram que não é possível apontar o ambiente como o principal determinante da estrutura, pois os estudos evidenciam que algumas organizações operam em ambientes similares e apresentam diferentes estruturas e outras têm estruturas semelhantes, apesar de operarem em ambientes diferentes. Embora não possa ser considerado o fator principal que determina a estrutura, alguns relacionamentos podem ser estabelecidos:

1) o efeito do ambiente na organização é uma função de dependência, 2) um ambiente dinâmico tem mais influência na estrutura do que um ambiente estático, 3) complexidade e incerteza ambiental são diretamente relacionadas, 4) formalização e incerteza ambiental são inversamente relacionadas, 5) quanto mais complexo o ambiente, maior a descentralização e 6) hostilidade extrema no ambiente conduz à centralização temporária. ${ }^{15}$ (Ibid., p. 233).

\footnotetext{
${ }^{15}$ (1) the environment's effect on an organization is a function of dependence, (2) a dynamic environment has more influence on structure than does a static one, (3) complexity and environmental uncertainty are directly related, (4) formalization and environmental uncertainty are inversely related, (5) the more complex the environment, the greater the decentralization, and (6) extreme hostility in the environment leads to temporary centralization.
} 
A quinta variável analisada pelo autor como possível determinante da estrutura organizacional é poder/controle. Sob o ponto de vista desta variável, os tomadores de decisão, ao definir a estrutura, procuram satisfazer as exigências de eficácia e também buscam atender os seus próprios interesses. Esse enfoque supõe que a pessoa ou grupo de pessoas que detém o poder na organização (chamados pelos teóricos de coalisão dominante) tem forte influência na definição da estrutura e que a tendência é optarem por uma estrutura que mantenha e reforce seu poder e, conseqüentemente, o controle na organização.

Robbins (1990, p. 270) conclui que não mais do que 50 a 60 por cento da variação na estrutura pode ser explicada pelas variáveis: estratégia, tamanho, tecnologia e ambiente, as quais foram analisadas anteriormente. Para o autor, a variável poder-controle pode ser responsável por grande parte das decisões relacionadas à definição da estrutura, tendo em vista a manutenção de poder através do desenho organizacional.

Além do poder formal estabelecido pelo cargo e pela posição hierárquica ocupada, outras fontes de poder existem na organização, como por exemplo, o conhecimento especializado (HALL, Richard, 2004, p. 94) e o controle de recursos escassos e importantes (ROBBINS, op. cit., p. 255). Sendo assim, a definição da estrutura é uma oportunidade para garantir a manutenção do poder e quem tem mais poder tem maior possibilidade de mantê-lo através da definição de uma estrutura que assim o favoreça. Segundo Mintzberg (2003, p. 167):

\footnotetext{
Tipicamente, todos os membros da organização procuram poder - se não para controlar outros, pelo menos para controlar as decisões que afetam seu próprio trabalho. Os dirigentes posicionados na cúpula estratégica promovem a centralização em ambas as dimensões vertical e horizontal; os gerentes da linha intermediária promovem a descentralização vertical, pelo menos abaixo de seus próprios níveis, e a centralização horizontal para manterem o poder na estrutura de linha; os analistas e os assessores de apoio favorecem a descentralização horizontal para retirar poder dos gerentes de linha; e os operadores buscam a total descentralização vertical e horizontal no núcleo operacional.
}

Considerando as pesquisas analisadas por Robbins (1990), Richard Hall (2004) e Mintzberg (2003) e suas conclusões a respeito das mesmas, é possível entender que não existe uma explicação única para as formas de organização. É necessário considerar conjuntamente diversas variáveis para compreender a estrutura organizacional. Richard Hall (op. cit., p. 100) descreve bem esse entendimento: 
Existem, portanto, diversas explicações para a estrutura. Quando essas explicações são consideradas individualmente, em oposição entre si, e fora de seu contexto histórico e cultural, possuem pouco a oferecer. Quando combinadas e inseridas no contexto, elas nos permitem compreender porque as organizações assumem as formas que apresentam.

Tendo em vista a teoria proposta por Robbins (1990), com os três componentes da estrutura organizacional e as cinco variáveis que desempenham forte influência na definição da melhor estrutura, pode-se perceber que não é tarefa fácil para o gestor escolher, entre as diversas possibilidades, a melhor combinação desses elementos. Para entender melhor como proceder à análise das possibilidades e definir a estrutura mais adequada para cada situação é importante considerar as teorias existentes sobre design organizacional, ou como normalmente é traduzido, desenho organizacional.

\subsubsection{Design organizacional}

Para Robbins (1990, p. 6), “Design organizacional se refere à construção e mudança de uma estrutura organizacional para alcançar as metas da organização.”16

O termo desenho organizacional, diz respeito ao processo de determinar e implementar a estrutura organizacional mais adequada à empresa, tendo em vista seus recursos, missão, objetivos, ambiente, tecnologia, tamanho e outras variáveis que porventura possam interferir nessa escolha.

É importante salientar que ainda não existe uma teoria consolidada sobre desenho organizacional, que obtenha consenso entre os teóricos. Muitas propostas existem e os administradores precisam escolher entre estas o quadro teórico mais adequado à realidade da empresa.

\footnotetext{
Algumas teorias afirmam que 'há o melhor método’ para montar e planejar a organização e damos a estas teorias o nome de teorias universais. Outras afirmam que a estrutura ótima pode variar de situação para situação, dependendo de fatores tais como tecnologia e diferenças ambientais e estas teorias recebem o nome de teorias contingenciais. (GIBSON et al, 1981, p. 270).
}

\footnotetext{
16 "Organization design is concerned with constructing and changing an organization's structure to achieve the organization's goals.”
} 
Dentre as teorias universais estão as correntes de pensamento denominadas administração científica (Taylor, Gilbreth, Gantt), teoria clássica da organização (Fayol, Mooney, Reiley) e teoria burocrática (Weber). As primeiras idéias e tentativas de solucionar os problemas organizacionais de forma mais estruturada surgiram no final do século XIX e deram origem à administração científica. Depois vieram as demais teorias apresentando evoluções, mas tendo como princípio básico a crença de que existe uma maneira “ótima” de organizar.

As teorias contingenciais representam as tentativas mais recentes de entender e solucionar os problemas organizacionais relacionados à estrutura. Elas acreditam que as estruturas precisam ser ajustadas para se adaptar a situações diversas, as quais as organizações são submetidas, e que não há um único modelo, mas sim um modelo diferente para cada situação existente. Dentre essas teorias estão as correntes de pensamento que procuram relacionar como fator determinante da estrutura as variáveis: tecnologia, ambiente, tamanho da organização, podercontrole e estratégias, já comentadas anteriormente.

Um modelo que é representativo das teorias universais e que ainda é amplamente encontrado nas empresas é a burocracia. Pela definição de Max Weber, sociólogo alemão que propôs o modelo, burocracia é um tipo ideal de organização racional e eficiente, cujas características são “[...] divisão do trabalho, uma hierarquia de autoridade bem definida, alta formalização, relações impessoais, decisões sobre o emprego baseadas em mérito, expectativa de carreira do empregado e separação entre a vida pessoal e profissional dos membros.”17 (ROBBINS, 1990, p. 325).

A burocracia possui duas vertentes: burocracia mecanizada e burocracia profissional. Na burocracia mecanizada o ponto chave é a padronização dos processos de trabalho. Segundo Mintzberg (2003, p. 186) essa estrutura se configura da seguinte forma:

\footnotetext{
Tarefas operacionais rotineiras e altamente especializadas; procedimentos muito formalizados no núcleo operacional; proliferação de normas, regulamentos e comunicação formalizada em toda a organização; grandes unidades no nível operacional; confiança na base funcional para agrupamento das tarefas; poder de tomada de decisão relativamente centralizado; e estrutura administrativa elaborada com nítida distinção entre linha e assessoria.
}

\footnotetext{
${ }^{17}$ “[...] division of labor, a well-defined authority hierarchy, high formalization, impersonal relations, employment decisions based on merit, career tracks for employees, and distinct separation of members' organizational and personal lives."
} 
Na segunda vertente, a burocracia profissional, o trabalho é complexo e deve ser controlado pelas pessoas que o executam, gerando uma estrutura mais descentralizada. O foco da padronização não recai nos processos de trabalho e sim nas habilidades e conhecimentos necessários para realizar os trabalhos complexos. Para Mintzberg (2003, p. 213):

\begin{abstract}
A burocracia profissional baseia-se na coordenação da padronização das habilidades e em seus parâmetros de design associados, o treinamento e a doutrinação. Contrata profissionais especializados, devidamente treinados e doutrinados, para o núcleo operacional e, depois, concedelhes considerável controle sobre seu próprio trabalho.
\end{abstract}

Embora exista muita discussão sobre as exigências de flexibilidade para a empresa ser mais dinâmica no ambiente competitivo no qual está inserida, a forma estrutural mais encontrada ainda é a burocracia.

[...] a burocracia mecanizada permanece uma configuração dominante - provavelmente a dominante em nossas sociedades especializadas. Enquanto demandarmos bens e serviços baratos e padronizados e mais pessoas permanecerem tão eficientes quanto máquinas automáticas para fornecê-los - e continuarem dispostas a fazer isso -, a Burocracia Mecanizada, com todos os seus problemas, estará conosco. (Ibid., p. 211).

Outro modelo também encontrado atualmente nas empresas, e que é representativo das teorias contingenciais, é a adhocracia. Robbins (1990, p. 354) a define como um “[...] sistema que muda rapidamente, adaptativo, geralmente temporário, organizado em função de problemas a serem resolvidos por grupos de pessoas relativamente estranhas com habilidades profissionais diversas."18 Tem como características: de moderada a baixa complexidade, baixa formalização e tomada de decisão centralizada e maior possibilidade de adaptação a ambientes mais dinâmicos e complexos, ou ainda quando as empresas estão nos primeiros anos de vida. É necessário ressaltar que nos últimos anos esse modelo tem sido muito discutido, mas que efetivamente poucas empresas o utilizam. Na maioria das vezes, existe nas empresas um misto entre adhocracia e burocracia.

A literatura apresenta diversas formas estruturais que são na verdade extensões dos modelos burocrático e adhocrático.

As estruturas do tipo funcional, por clientes, por produtos, por processos, entre outras,

\footnotetext{
18 “[...] a rapidly changing, adaptive, usually temporary system organized around problems to be solved by groups of relative strangers with diverse professional skills."
} 
consideradas tradicionais, são exemplos de estruturas baseadas no modelo burocrático. Estruturas do tipo matriz, por projetos, consideradas inovativas, são exemplos de estruturas baseadas no modelo adhocrático.

De forma geral, a grande diferença entre essas formas estruturais é a maneira pela qual as atividades desenvolvidas na organização são agrupadas, tendo em vista os objetivos da organização, o que é conhecido como departamentalização. A realidade das empresas demonstra que nenhuma forma específica de departamentalização consegue abranger todas as características necessárias para a estruturação de uma organização. O que se percebe é uma combinação e interação dessas formas estruturais.

\subsubsection{Estrutura de cargos}

Os cargos são partes integrantes do formato estrutural da organização. Ao agrupar as atividades existentes na empresa em cargos e distribuí-los aos diversos setores, definindo autoridade, níveis hierárquicos e linhas de comunicação, a estrutura organizacional está sendo criada.

Dessa forma, quando por algum motivo houver mudanças na estrutura organizacional da empresa, é possível também que elas afetem os cargos direta ou indiretamente. Fica evidente, portanto, que os cargos não são estáticos, mas podem mudar para acompanhar a evolução da empresa e sua adaptação às mudanças ambientais.

Inicialmente, alguns termos relacionados à estrutura de cargos devem ser definidos. Zimpeck (1992) e Pontes (2000) têm o mesmo entendimento sobre as definições de tarefas, funções e cargos e sobre a lógica da determinação de um cargo.

[...] a tarefa existe como um conjunto de elementos que requer o esforço humano para determinado fim. Quando tarefas suficientes se acumulam para justificar o emprego de um trabalhador, surge a função. Assim, a função é um agregado de deveres, tarefas e responsabilidades que requerem os serviços de um indivíduo. [...] as funções que são semelhantes em sua natureza e requisitos são chamadas cargos. Portanto, o termo 'cargo' pode ser definido como 'um grupo de funções idênticas na maioria ou em todos os aspectos mais importantes das tarefas que as compõem.' (ZIMPECK, op. cit., p. 40).

É importante esclarecer que os termos tarefas e atividades, neste trabalho, são utilizados como sinônimos. De acordo com tais definições citadas acima, sempre que houver alterações nas 
atividades existentes na empresa, na forma de agrupar essas atividades, nos requisitos exigidos para que as pessoas realizem tais atividades, a estrutura de cargos deve ser revista e atualizada.

No sentido inverso, uma alteração na estrutura de cargos também pode ser utilizada como agente de mudanças na estrutura organizacional, seja para ampliar o leque de funções contidas em cada cargo (auxiliando a redução de níveis hierárquicos), seja para descentralizar a autoridade para a tomada de decisões, seja para facilitar a comunicação entre os setores etc.

Seguindo a teoria sobre estrutura de cargos apresentada por Pontes (2000), que coincide quase que totalmente com a teoria apresentada por Zimpeck (1992), ao analisar um cargo é preciso observar dois aspectos principais: o conteúdo e as especificações do cargo.

O conteúdo diz respeito às atividades desempenhadas pelas pessoas. Responde às perguntas: O QUE FAZ, COMO FAZ e PORQUE FAZ. As especificações são os requisitos, ou seja, as qualificações que as pessoas precisam apresentar para realizar com sucesso as atividades previstas. As grandes áreas a serem observadas para a identificação dos requisitos do cargo são: mental, física e responsabilidade.

\footnotetext{
Geralmente, a chave usada para se obter o conteúdo do cargo, consiste em saber em detalhes o QUE o empregado faz, COMO faz e PORQUE faz. Já o estudo dos requisitos diz respeito a informações do empregado tratadas em caráter precário e que devem ser confirmadas com o supervisor, sendo finalmente julgadas pelo próprio Analista, para determinar, por exemplo: o grau de conhecimentos necessários para o bom desempenho do cargo; a experiência prática exigida;

o esforço físico e mental; as responsabilidades, etc. (Ibid., p. 53).
}

O Quadro 1, abaixo, ilustra alguns fatores referentes à análise de cargos a serem observados em cada área. 


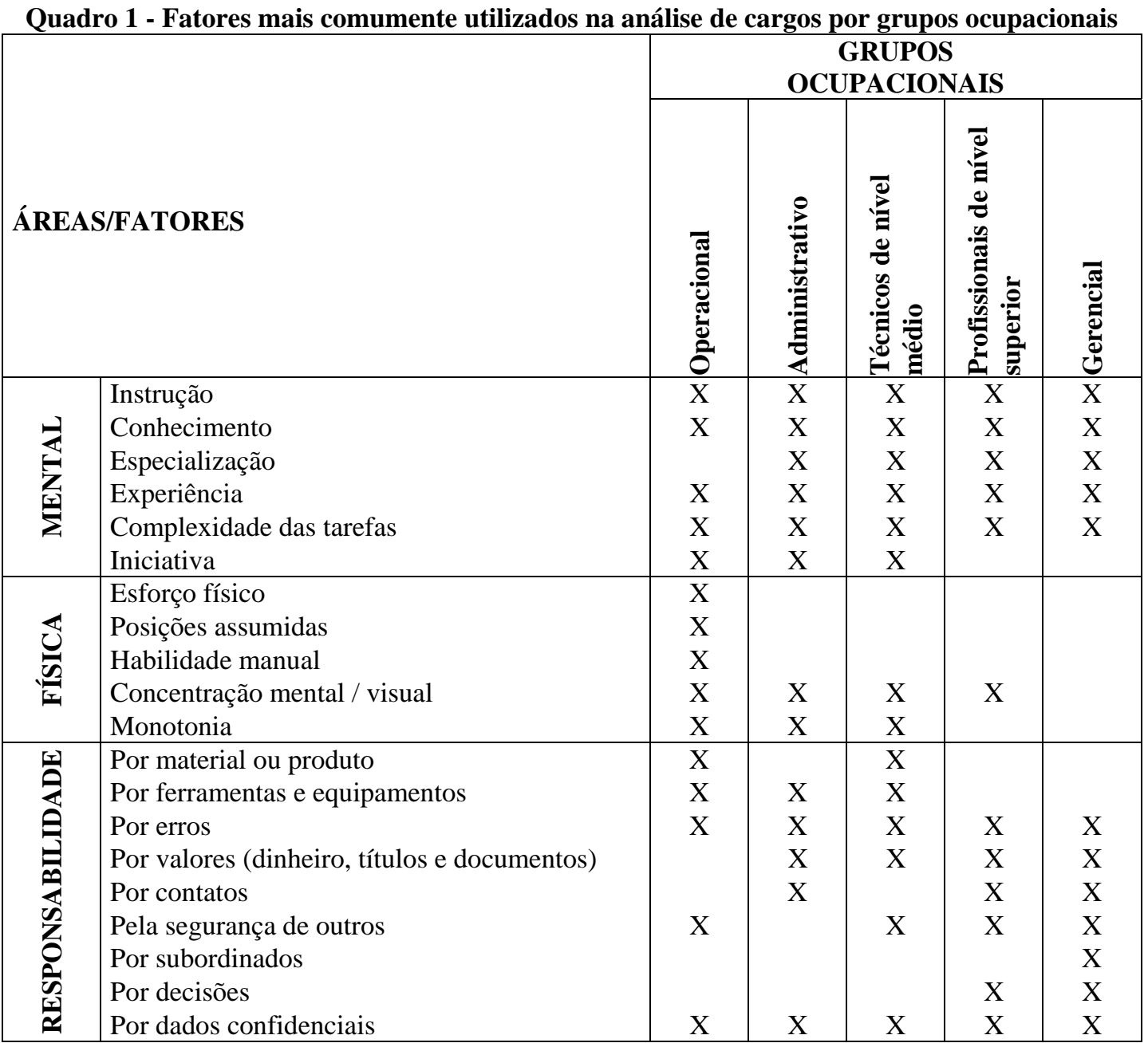

FONTE: Adaptado de PONTES, 2000, p. 45.

O esforço em analisar cada cargo com seu conteúdo e especificações culmina com a descrição de cargos. Segundo Zimpeck (1992, p. 39), descrição de cargos “[...] é a composição das atividades correlatas da empresa e que expressam o conteúdo e requisitos semelhantes.” O formato mais comum da descrição de cargos é apresentado no Quadro 2: 
Quadro 2 - Descrição de cargos

\begin{tabular}{|l|}
\hline Título do Cargo: \\
\hline Unidade: \\
\hline Descrição Sumária: \\
\hline Descrição Detalhada: \\
\hline Especificação \\
\hline 1 - instrução \\
2 - conhecimentos \\
3 - especialização \\
4 - experiência \\
5 - iniciativa / complexidade \\
6 - concentração mental / visual \\
7 - monotonia \\
8 - responsabilidades \\
\hline Data:
\end{tabular}

FONTE: Adaptado de PONTES, 2000, p. 82.

Um critério importante a ser considerado na elaboração da descrição de cargos é que nela não deve constar o que o empregado pode fazer e sim o que ele realmente faz.

Teoricamente, a implementação de um ERP deveria mudar substancialmente o modo de desenvolver as atividades na Contabilidade. Por exemplo, uma das atividades que sofre alteração é o registro contábil das transações, já que a entrada de dados ocorre na origem da transação (ex: momento da venda e momento da compra) e não mais precisa ser repetida na área de Contabilidade.

Para dar suporte à análise sobre a influência do ERP nas atividades da área contábil foi necessário rever alguns pontos sobre a Contabilidade enquanto ciência e enquanto setor administrativo que desempenha atividades para fornecer informações aos usuários.

\subsection{Sistema de Informações Contábeis}

\subsubsection{Objetivo da Contabilidade}

Adotou-se neste trabalho o entendimento de que a Contabilidade é uma ciência que tem por objetivo retratar o mais fidedignamente possível o patrimônio das entidades e suas mutações. 
A Contabilidade trabalha, essencialmente, com informações, ou seja, ela informa sobre o patrimônio e só o faz porque existe o interesse de alguém em obter tais informações, neste caso, seus usuários - acionistas das empresas, entidades governamentais, administradores, empregados, fornecedores, agências de financiamento, entre outros.

Para conseguir retratar o patrimônio e os fenômenos que provocam suas variações, foi preciso criar mecanismos para interpretá-los, desenvolver normas e técnicas para representá-los, bem como criar um padrão de comunicação (muitos chamam de linguagem de negócios) de forma que os usuários pudessem compreender o que era evidenciado.

Toda a teoria contábil dedica esforços nesse sentido, como também para identificar a estrutura fundamental da Contabilidade - um corpo teórico que sustenta todas as normas e regras criadas para evidenciar a realidade de forma cada vez mais compreensível, fidedigna e útil. Isso não é tarefa fácil, pois os usuários da informação são variados e têm interesses distintos. Como a informação deve ser válida para todos, a mesma situação ou evento precisa ser demonstrada sob várias facetas.

Com a evolução da sociedade, os interesses dos usuários pela informação contábil também tendem a mudar, acompanhando esse desenvolvimento. Da mesma forma, a teoria da Contabilidade está em evolução, não havendo nada de definitivo, terminado, verdades absolutas, aliás, com deve ser com qualquer teoria.

No cotidiano de uma empresa, obter e fornecer as informações significa coletar os dados sobre o que acontece com o patrimônio, processá-los de acordo com os mecanismos e os padrões criados pela teoria e, em seguida, informar o resultado. Isso está de acordo com a lógica de sistemas de informação, ou seja, entrada de dados, processamento desses dados e saída na forma de informação, não importando se os padrões de hoje serão os mesmos amanhã. Se mudarem as regras, os mecanismos de avaliação do patrimônio ou os padrões para a evidenciação das informações, ainda assim, a lógica de sistema se mantém.

Dessa forma, a Contabilidade é considerada em sua essência um sistema de informação, ou seja, o sistema de informações contábeis (SIC). 
No entendimento sobre o que é a Contabilidade e seu objetivo, divulgado pelo IBRACON (Instituto Brasileiro de Contadores), está implícita a visão de sistema. Essa definição é parte de um estudo elaborado pelo IPECAFI (Instituto de Pesquisa Contábeis, Atuariais e Financeiras), aprovado e divulgado pelo IBRACON e referendado pela CVM (Comissão de Valores Mobiliários), chamado "Estrutura Conceitual Básica da Contabilidade”, no qual a Contabilidade é tratada como “[...] um sistema de informação e avaliação destinado a prover seus usuários com demonstrações e análises de natureza econômica, financeira, física e de produtividade, com relação à entidade objeto de contabilização.” (FIPECAFI, 1995, p. 58). Detalhando essa definição, obtém-se:

a) Informação de natureza econômica e financeira: informações sobre receitas, despesas, capital e o patrimônio representam o aspecto econômico, e informações sobre fluxo de caixa e capital de giro representam o aspecto financeiro.

b) Informação de natureza física: vai além dos valores monetários para informar sobre itens não financeiros como quantidade de produto ou serviço, número de funcionários etc.

c) Informação de natureza de produtividade: utiliza um misto de informação financeira e não financeira como receita per capta, depósitos por cliente etc.

Dessa forma, é amplo o escopo da Contabilidade, pois além de fornecer informações de caráter monetário e não monetário, a Estrutura Conceitual Básica também prevê que as informações devem ter utilidade para o usuário no processo de tomada de decisão.

O sistema de informações contábeis está interligado a outros sistemas de informação, como por exemplo, os que processam as transações referentes às vendas e à produção. O conjunto de todos estes formam um sistema de informação mais amplo, que abrange a organização como um todo e é responsável pelo fluxo de informações que permite que as atividades sejam executadas.

Entretanto, uma característica do SIC é que todas as transações que ocorrem na empresa são, em última instância, registradas nele. Assim, numa venda a prazo, o início é o registro da própria transação da venda que gera diversos relatórios, passa pelo registro de contas a receber, que gera outros relatórios de controle e termina com o registro do recebimento, que alimenta o caixa e a baixa em contas a receber. Tudo isso é captado pela Contabilidade. Pode- 
se dizer, portanto, que o SIC consolida as informações de todas as atividades que ocorrem numa empresa. Dessa forma, o objetivo da Contabilidade em retratar o patrimônio e suas mutações é atendido.

No campo teórico, há uma discussão sobre os limites do sistema de informações contábeis. Alguns autores afirmam que ele é restrito à área de Contabilidade. Outros entendem que ele é mais amplo. Na seqüência são apresentados esses dois enfoques.

\subsubsection{Abordagem restrita versus abordagem expandida}

Riccio (1989) estabeleceu para o Sistema de Informações Contábeis a abordagem restrita e a abordagem expandida. Sob a abordagem restrita, o SIC está limitado à área de Contabilidade das empresas. Já sob a abordagem ampliada, este sistema tem condições de ser o principal sistema de informação da empresa, cujos objetivos são: “(1) prover informações monetárias e não-monetárias destinadas às atividades e decisões dos níveis operacionais, tático e estratégico da empresa e dos usuários externos e (2) constituir-se na peça fundamental do Sistema de Informação Gerencial da empresa.” (Ibid., p. 57). Os tópicos seguintes discutem estas abordagens com detalhes.

\subsubsection{Abordagem restrita}

O Sistema de Informações Contábeis sob o enfoque restrito pode ser entendido da seguinte maneira:

\footnotetext{
O SIC tradicionalmente se concentrava na coleta, no processamento e no fornecimento de informações de cunho financeiro para partes externas à companhia (como investidores, credores e órgãos da receita) e partes internas (principalmente a administração). Hoje, no entanto, ele está interessado tanto em dados e informações financeiros quanto não financeiros. Sob o conceito tradicional de SIC, cada área funcional da organização, como marketing, produção, finanças e recursos humanos, mantém um sistema de informações separado. (MOSCOVE et al, 2002, p. 24).
}

Tradicionalmente, o SIC é visto como um sistema que atende à área de Contabilidade das entidades. Os dados inseridos (entradas) são oriundos de sistemas operacionais das diversas áreas da empresa como vendas, compras, contas a receber, contas a pagar etc. Após receber esses dados, o SIC os processa obedecendo à lógica das partidas dobradas, às normas contábeis e também às exigências da legislação pertinente e tem como saídas diversos 
relatórios como o balanço patrimonial, a demonstração de resultado, entre outros. Também podem ser saídas do SIC, sob essa perspectiva mais tradicional, relatórios que não obedecem à legislação, mas que atendem às necessidades gerenciais e que são voltados exclusivamente aos usuários internos. É o que conhecemos por Contabilidade Financeira e Contabilidade Gerencial, respectivamente.

De acordo com esse enfoque, o SIC é um dos subsistemas do sistema de informação total da empresa juntamente com os subsistemas de compras, de vendas, de contas a receber, de contas a pagar etc., e as saídas desses subsistemas são entradas para o SIC, como ilustra a Figura 4, abaixo:

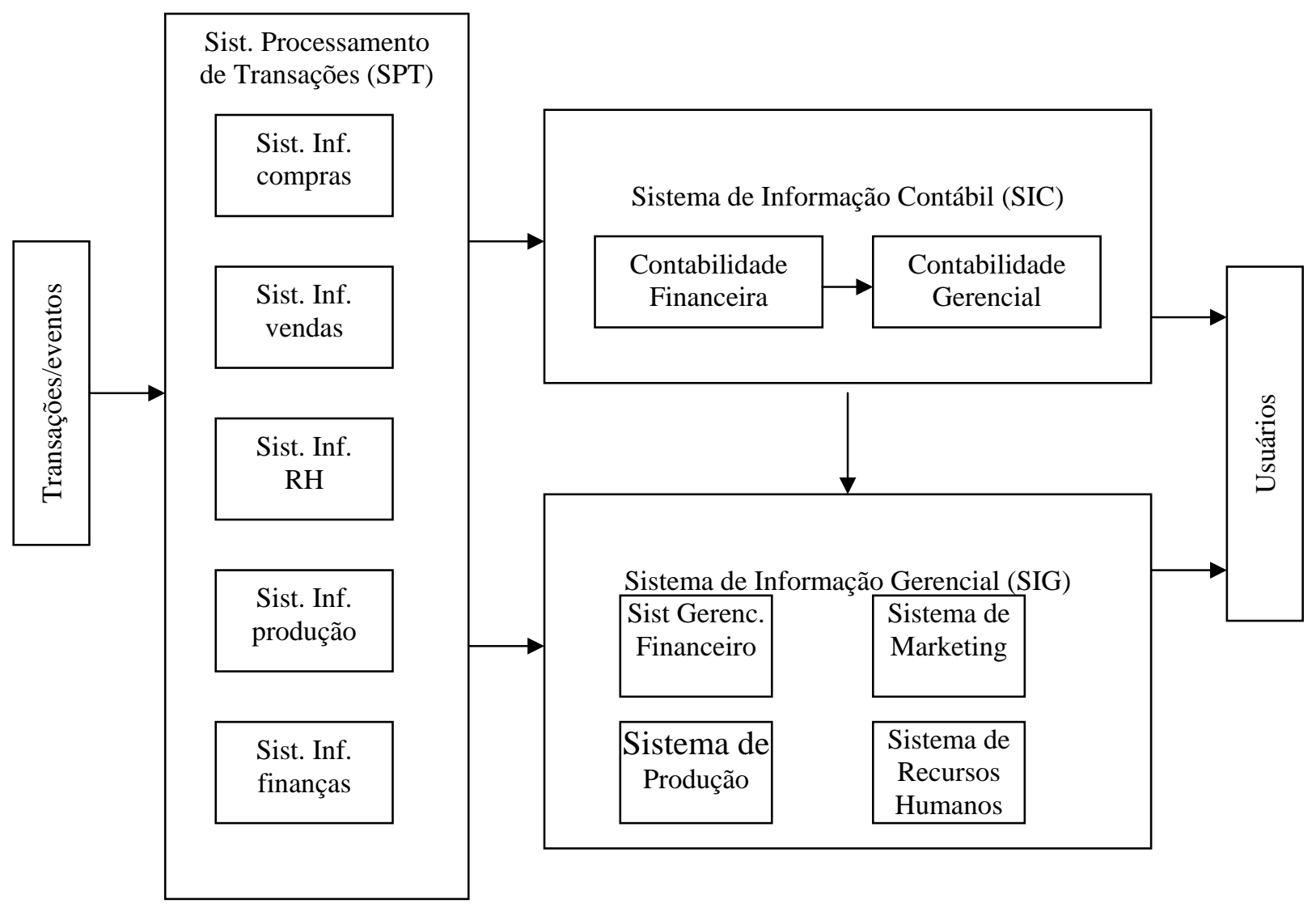

Figura 4 - Visão Restrita do Sistema de Informação Contábil FONTE: Adaptado de RICCIO, 1989, p.81

\subsubsection{Abordagem expandida}

Sob a visão ampliada, o Sistema de Informações Contábeis não contempla apenas a área de Contabilidade, mas extrapola aos sistemas de informações operacionais da empresa ou, como 
também é chamado, sistema de processamento de transações (SPT). Verifica-se algumas definições dentro dessa visão expandida de SIC:

Definimos os SICs como sistemas de informações que captam, registram e comunicam todas as informações financeiras e não financeiras relativas a importantes atividades empresariais. Essa perspectiva leva à criação de informações mais úteis e oportunas para fins de planejamento, tomada de decisões e controle. (MOSCOVE et al, 2002, p. 25).

Os autores acreditam que o SIC também deve fornecer informações não financeiras úteis para tomada de decisão e para outras atividades empresariais como planejamento e controle. As “importantes atividades empresarias” são vendas, compras, contas a receber etc. Nessa visão, a gestão, como um todo, está sendo suprida com informação contábil útil. Isso inclui necessariamente a existência da Contabilidade Financeira e também da Contabilidade Gerencial.

Já para James Hall (2001, p. 9):

Os subsistemas do SIC processam transações financeiras e não financeiras que afetam diretamente as transações financeiras. O SIC é formado por três subsistemas principais: 1) o sistema de processamento de transação (SPT), que suporta as operações diárias com numerosos documentos e mensagens para usuários por toda a organização; 2) o razão geral e sistema de demonstrações financeiras, que produz as demonstrações financeiras tradicionais, tais como demonstração de lucro, balanço patrimonial, demonstração de fluxo de caixa, declaração de renda, e outras demonstrações solicitadas pela legislação; e 3) o sistema de demonstrações gerenciais, que fornece aos gerentes internos informações e relatórios financeiros especiais para a tomada de decisão tais como orçamentos, relatórios de variação, e relatórios de responsabilidade. ${ }^{19}$

Esse segundo autor também menciona o aspecto financeiro e não financeiro da informação e detalha como o SIC é formado, evidenciando sua amplitude. Ele deixa explícito que o SIC abrange as atividades típicas da área de Contabilidade, que são a elaboração dos registros contábeis e as demonstrações, tanto as exigidas pela legislação vigente e voltadas mais aos usuários externos, quanto as solicitadas internamente para atender o processo de gestão e que não precisam obedecer a nenhum rigor de legislação.

\footnotetext{
${ }^{19}$ AIS subsystems process financial transactions and nonfinancial transactions that directly affect the processing of financial transactions. The AIS comprises three major subsystems: (1) the transaction processing system (TPS), which supports daily business operations with numerous documents and messages for users throughout the organization; (2) the general ledger/financial reporting system (GL/FRS), which produces the traditional financial statements, such as the income statement, balance sheet, statement of cash flows, tax returns, and other reports required by law; and (3) the management reporting system (MRS), which provides internal management with special-purpose financial reports and information needed for decision making, such as budgets, variance reports, and responsibility reports.
} 
Mas não se limita a isso. O autor afirma que também faz parte do SIC o processamento de todas as transações que ocorrem na empresa, como as relacionadas às atividades das áreas de vendas, de compras, de recursos humanos, de contas a pagar, de contas a receber, de ativo fixo, de investimentos e outras que eventualmente sejam desenvolvidas. Isso significa que o SIC torna-se um grande sistema de informação que recebe e processa todos os dados das atividades desenvolvidas na empresa, mas que além dele a empresa conta com um sistema de informação gerencial que atende às necessidades de caráter mais estratégico.

Para Wilkinson (2000, p. 7):

Um sistema de informações contábeis é uma estrutura unificadora dentro de uma entidade, tal como uma empresa, que emprega recursos físicos e outros componentes para transformar dados econômicos em informações contábeis, com o propósito de satisfazer a necessidade de informação de uma variedade de usuários. ${ }^{20}$

Nessa definição é ressaltado o aspecto consolidador do SIC, significando que o sistema é estruturado de tal maneira que todos os dados registrados na empresa convergem para o processamento contábil, o qual produz informações variadas para atender às necessidades informacionais dos diversos usuários da informação contábil.

Essa visão mais ampla do SIC é ilustrada na Figura 5, abaixo:

\footnotetext{
${ }^{20}$ An accounting information system is a unified structure within an entity, such as a business firm, that employs physical resources and other components to transform economic data into accounting information, with the purpose of satisfying the information needs of a variety of users.
} 


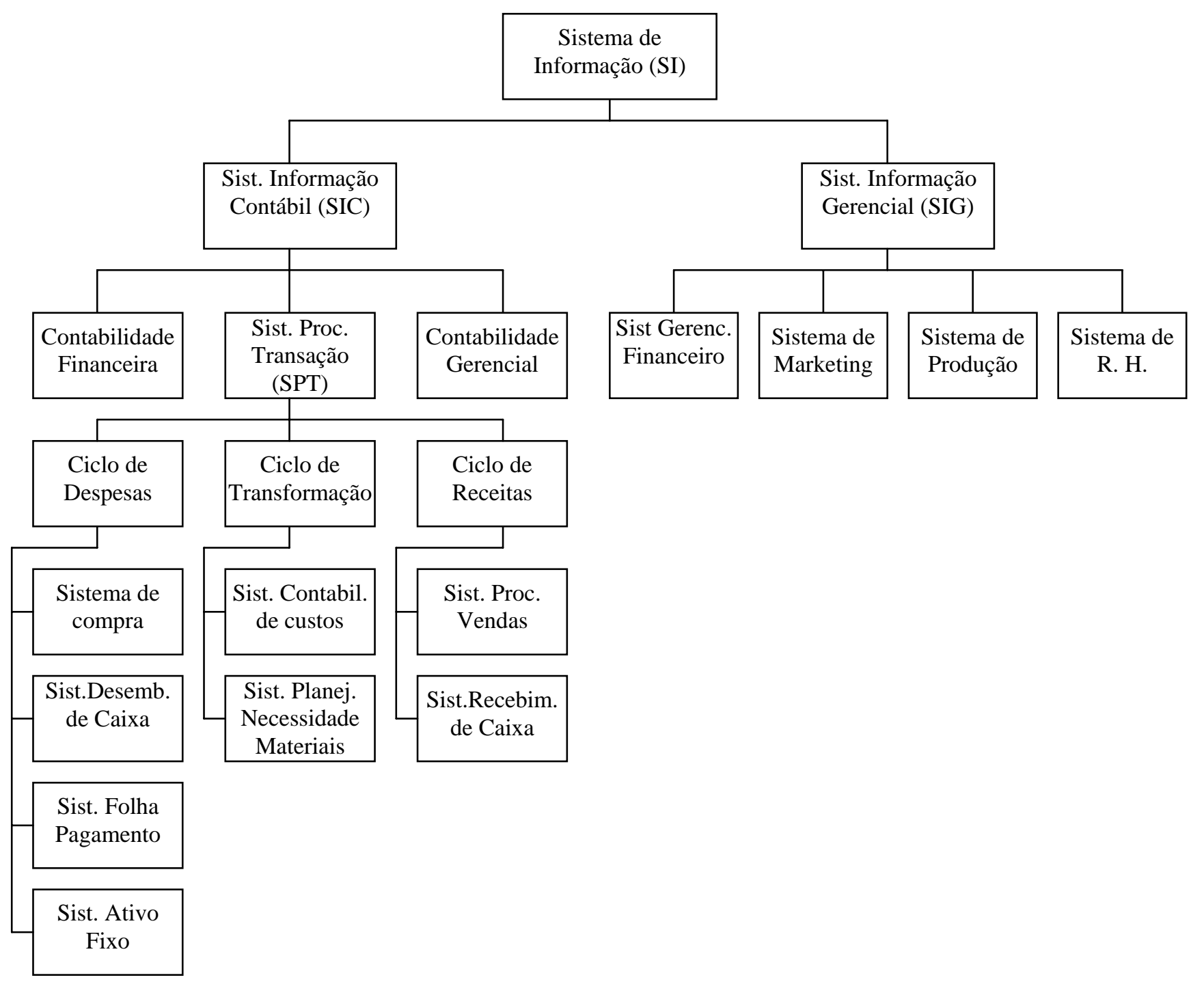

Figura 5 - Visão Ampliada do Sistema de Informação Contábil

FONTE: HALL, James, 2001, p. 8

É grande a discussão que gira em torno dessa definição de amplitude do SIC (visão restrita x visão ampliada), e também importante, pois a Contabilidade de fato tem o potencial de ser o grande sistema da empresa, tendo em vista sua característica de sistema consolidador e o desenvolvimento tecnológico atual que possibilita essa implementação. 
Na visão ampliada, com o apoio da TI, o foco dos SICs está voltado para a captação de dados sobre os processos de negócio. “A Contabilidade operacional focaliza processos de negócio, isto é, um conjunto de atividades ou fluxo de trabalho numa organização que cria valor. Exemplos de processos de trabalho são o processo de receitas e o processo de despesas.” (MOSCOVE et al, 2002, p. 25).

Sendo assim, conforme demonstrado na Figura 5, além da Contabilidade Financeira e da Contabilidade Gerencial, também faz parte do SIC o Sistema de Processamento de Transações, que organiza e processa os dados dos diversos processos de negócio de uma empresa, ou seja, dos ciclos de despesas, de receitas e de transformação, este último referente ao processo de produção. Isso significa que o Contador é responsável pelo fluxo de informações de todos os processos de negócio, uma mudança radical em relação ao seu escopo de atuação no SIC tradicional, que era apenas relacionado às atividades internas da área de Contabilidade. Para melhor entendimento, o SIC, sob o enfoque ampliado, é detalhado abaixo:

\subsection{Contabilidade financeira}

Começa quando o pessoal da área de Contabilidade analisa uma transação, baseado em um documento fonte, e termina com o fechamento contábil e emissão das demonstrações contábeis.

\footnotetext{
O pessoal da Contabilidade lança as transações num diário. O diário é um registro cronológico dos eventos por conta. A estrutura de conta de uma organização é seu plano de contas. [...] uma vez feito um lançamento no diário, em seguida o SIC faz o lançamento no razão geral. Dentro do SIC, o razão geral é um conjunto de informações monetárias detalhadas sobre os diversos ativos e passivos, o capital, as receitas e as despesas de uma organização. [...] uma vez feitos os lançamentos no diário e no razão geral, o SIC gera um balancete de verificação. Esse balancete é uma listagem dos saldos credores e devedores de todas as contas. [...] depois de gerar o primeiro balancete, são feitos os ajustes como depreciação, despesas pagas antecipadamente etc. e na seqüência é gerado outro balancete. (MOSCOVE et al, 2002, p. 104).
}

Após a conferência do balancete, procede-se ao encerramento das contas e a elaboração das demonstrações contábeis, que incluem Demonstração do Resultado do Exercício, Balanço Patrimonial, Demonstração das Mutações do Patrimônio Líquido, Demonstração das Origens e Aplicações de Recursos, Demonstração do Fluxo de Caixa e, eventualmente, outros relatórios solicitados. 
Além dessas demonstrações, a legislação determina alguns procedimentos relativos ao controle de impostos e contribuições como o ICMS (imposto sobre circulação de mercadorias e serviços), imposto de renda, imposto sobre serviços, PIS (programa de integração social), COFINS (Contribuição para Financiamento da Seguridade Social), entre outros, o que inclui o preenchimento de livros e formulários, bem como a preparação de guias para recolhimento.

Algumas características da Contabilidade Financeira são mencionadas na definição proposta por Atkinson et al (2000, p. 37):

\begin{abstract}
A informação contábil-financeira comunica aos agentes externos as conseqüências das decisões e das melhorias dos processos executadas por administradores e funcionários. O processo contábilfinanceiro está restrito aos requisitos obrigatórios de elaboração de relatórios por parte das autoridades regulamentadoras externas [...] conseqüentemente, a Contabilidade Financeira tende a ser direcionada por regras, e os estudantes de Contabilidade Financeira estudam lançamentos no diário e procedimentos que geram os demonstrativos financeiros obrigatórios.
\end{abstract}

Além de ser direcionada aos usuários externos e atender às exigências da legislação, outras características da Contabilidade Financeira, segundo os mesmos autores, seriam: apresenta informações sobre o desempenho passado; é mais restrita à mensuração financeira; a informação é mais objetiva, auditável, confiável, consistente e precisa; é apresentada de forma mais agregada. (Ibid., 2000, p. 37)

\title{
2.3.2.2.2 Contabilidade gerencial
}

A Contabilidade Gerencial pode ser entendida como:

[...] o processo de identificar, mensurar, reportar e analisar informações sobre os eventos econômicos das empresas [...] processo de produzir informação operacional e financeira para funcionários e administradores. $\mathrm{O}$ processo deve ser direcionado pelas necessidades informacionais dos indivíduos internos da empresa e deve orientar suas decisões operacionais e de investimentos. (ATKINSON et al, 2000, p. 36).

Nessa definição, o termo informação operacional significa a informação não financeira. Além das características citadas na definição, outras apontadas foram: a informação é atual, orientada para o futuro; é mais subjetiva e sujeita a juízo de valor; é apresentada de forma mais desagregada, mais detalhada. 
Na Contabilidade Gerencial, as atividades mais comuns são a elaboração de orçamentos, a avaliação de desempenho e a análise de custos. Segundo Atkinson et al (2000, p. 37), são funções da informação gerencial contábil o controle operacional, o custeio do produto e do cliente, o controle administrativo e o controle estratégico.

São exemplos de informações gerenciais: custo e lucratividade por produto, por segmento, por departamento, por unidade; comparação entre custo padrão e real para os itens do orçamento, entre outros.

Atkinson et al (op. cit., p. 38) comentam também que até o século XIX, a informação contábil gerencial tinha mais ênfase e que no século XX, por ter aumentado as exigências das agências reguladoras, a Contabilidade Financeira recebeu mais atenção, relegando a gerencial ao segundo plano. Todavia, as empresas precisam da informação gerencial e se a Contabilidade não a produz outras áreas assumem esse papel, restringindo à área contábil apenas a responsabilidade pela Contabilidade Financeira, que não é menos importante, mas que é apenas uma parte do que a Contabilidade é capaz de realizar.

Embora tenham características distintas, a Contabilidade Financeira e a Gerencial são complementares para o alcance do objetivo de atender às necessidades dos usuários, já que uma é voltada aos usuários externos e a outra aos internos. Além disso, os dados que representam as entradas da Contabilidade Financeira também são utilizados na Contabilidade Gerencial. Portanto, a Contabilidade Gerencial utiliza as mesmas entradas que a Contabilidade Financeira e vai além, pois também necessita de dados não-financeiros.

\subsection{Sistema de processamento de transações}

É composto pelos ciclos de receita, de despesa e de transformação. Um breve comentário sobre cada ciclo é apresentado abaixo. 


\section{Ciclo de Receita}

Segundo James Hall (2001, p. 52), o ciclo da receita começa com um pedido de bens ou serviços por um cliente e encerra com o recebimento do pagamento feito pelo cliente: “As empresas vendem seus produtos aos clientes através do ciclo de receitas, o qual envolve o processamento das vendas a vista, das vendas a prazo, e o recebimento do pagamento referente às vendas a prazo."21

Para Moscove et al (2002, p. 113):

O objetivo principal do processamento de receita é obter um recebimento de caixa eficiente e pontual [...] a previsão é outro objetivo do ciclo das receitas. Para um SIC poder ajudar a função de planejamento da administração, ele deve ter a capacidade de prever receitas e entradas de caixa.

São entradas desse ciclo: o pedido de compra pelo cliente, a fatura, o aviso de remessa, a nota fiscal de entrega e o memorando de crédito/débito. São saídas: os relatórios financeiros, o relatório de faturas emitidas, o relatório de vencimento de faturas, o relatório de devedores duvidosos, a previsão de recebimento de caixa, a lista de clientes e os relatórios de análise de vendas.

\section{Ciclo de Despesa}

Segundo James Hall (op. cit., p. 50), “As atividades nas empresas começam com a aquisição de materiais, ativos fixos e trabalho em troca de dinheiro - o ciclo de despesas. ${ }^{22}$ Fazem parte deste ciclo os subsistemas de compras, de desembolso de caixa, de folha de pagamento e de ativo fixo.

O subsistema de compras registra a aquisição de materiais e conseqüentemente o aumento no inventário e estabelecimento da obrigação a ser paga. Algumas entradas desse subsistema são: requisição de compra, pedido de compra ao fornecedor, listagem de fornecedores, relatórios de recebimentos, nota de entrega e memorandos de débito/crédito. Algumas saídas são:

\footnotetext{
21 "Firms sell their finished goods to customers through the revenue cycle, wich involves processing cash sales, credit sales, and the receipt of cash following a credit sale."

22 "Business activities begin with the acquisition of materials, property, and labor in exchange for cash - the expenditure cycle."
} 
relatórios financeiros, cheques dos fornecedores, cadastro de cheques, relatórios de discrepâncias, previsão de necessidades de caixa e relatórios de análise de vendas.

O subsistema de desembolso de caixa autoriza o pagamento das obrigações e registra a redução do caixa e das contas a pagar.

O subsistema de folha de pagamento é responsável por coletar os dados referentes ao trabalho e remuneração dos funcionários, processar a folha de pagamento e registrar as obrigações fiscais e o pagamento dos salários. Algumas entradas desse subsistema são: formulários de atividade de pessoal, relatório de horas trabalhadas, autorização de deduções na folha de pagamento e formulários de retenção de impostos. Algumas saídas são: listagem de empregados, cheques dos empregados, borderô de cheques, relatórios de deduções, relatórios de impostos exigidos por lei e sumário da folha de pagamento.

O subsistema de ativo fixo registra as transações referentes à compra, manutenção, valorização e eliminação dos ativos fixos (também chamados ativos de longo prazo) de uma organização. Algumas entradas desse subsistema são: requisições de compras, relatórios de recebimento, faturas de fornecedores, pedidos de execução de construção, registros de manutenção e reparo e formulários de troca de ativo fixo. Algumas saídas são: informação de demonstrativo financeiro, registro de ativo fixo, registro de depreciação, relatórios de manutenção e reparo e relatório de ativos retirados.

\section{Ciclo de Transformação}

As empresas do ramo industrial transformam as matérias-primas em produtos acabados. Este ciclo começa com uma requisição de matérias-primas e termina com a transferência dos produtos acabados para o estoque. Os dois principais subsistemas desse ciclo são o de produção e o de Contabilidade de custos. 
O subsistema de produção, segundo James Hall (2002, p. 51), envolve o planejamento e controle da produção através de determinação das necessidades de materiais, autorização das ordens de serviço, e acompanhamento dos vários estágios da produção. O subsistema de Contabilidade de Custos controla o fluxo de informação de custo e calcula o custo dos produtos.

O que ocorre no dia-a-dia das empresas é que, embora esse enfoque ampliado seja adequado, tendo em vista que o processo contábil realmente começa com as transações de compras, vendas, produção, entre outras, o contador tem responsabilidade, de fato, apenas pelo subsistema de Contabilidade Financeira e Contabilidade Gerencial. Isso porque, para ser responsável por algo, é preciso ter o controle e a autoridade para tomar decisões sobre aquele objeto. Geralmente o contador não detém o controle e autoridade sobre o sistema de processamento de transações das empresas.

Entretanto, com o sistema ERP, esse cenário pode mudar. Como as entradas da Contabilidade são descentralizadas, o contador tem a responsabilidade tanto de orientar o desenvolvimento (customização) do ERP - para esclarecer sobre os reflexos de cada atividade para a Contabilidade, quanto de dar suporte aos funcionários na execução dos registros das transações. Isso permite que o contador esteja mais integrado com as atividades operacionais e tenha alguma autoridade, mesmo que informal, sobre os sistemas de processamento de transações.

\subsubsection{Conhecimentos e habilidades necessários ao contador}

Para estarem aptos a desenvolver as atividades ligadas à Contabilidade Financeira e Contabilidade Gerencial é preciso que os profissionais apresentem determinados conhecimentos e habilidades.

Muito se fala na necessidade de todo profissional estar atualizado com as mudanças que diariamente ocorrem no mundo globalizado. Cada vez mais, é preciso estar informado sobre os acontecimentos mundiais, conhecer e dominar novas tecnologias e novas técnicas para desempenhar as atividades. É preciso também dominar mais de um idioma, ter bom relacionamento interpessoal, ter controle emocional, entre outros conhecimentos e habilidades 
que normalmente são mencionados em discussões sobre perfil profissional.

Para o profissional da Contabilidade não é diferente. As contínuas mudanças na demanda por informações impulsionam o desenvolvimento da Contabilidade e o contador precisa estar atualizado para atender a essas necessidades.

Diante dessa realidade surge uma questão: Quais conhecimentos e habilidades deve ter o contador para desempenhar satisfatoriamente suas atividades?

Essa questão é discutida pelos diversos órgãos representativos da classe contábil, no Brasil e no exterior. Também é discutida pelas instituições de ensino que preparam esses profissionais, além de ser tema de pesquisas acadêmicas e de debates em diversos fóruns de discussão. $\mathrm{O}$ fato é que ainda não há consenso.

Neste trabalho, houve interesse em identificar os conhecimentos e habilidades necessários ao profissional da Contabilidade para desempenhar suas atividades, para verificar se ocorreram alterações nesses requisitos após a implementação de uma nova ferramenta de trabalho, o ERP, no caso, o software R/3 da SAP.

Como lembram Moscove et al (2002, p. 36), "O crescente uso da tecnologia da informação não apenas afeta a maneira como os contadores trabalham, como também lhes oferece oportunidades de expandirem seus serviços.” Dessa forma, a inclusão de uma nova tecnologia de informação pode alterar as atividades do contador o que, por conseqüência, pode exigir novas competências.

Para subsidiar a análise dos dados relacionados a este tema, foi adotado como quadro teórico o documento IEG (international education guidelines) $\mathrm{n}^{\circ}$ 9, emitido pela Federação Internacional dos Contadores (IFAC - International Federation of Accountants), visto que é uma posição respeitada internacionalmente.

A IFAC é uma associação sem fins lucrativos e não governamental que representa os interesses dos profissionais envolvidos com o exercício da Contabilidade. Emite guia de orientações sobre problemas do exercício profissional, ética e educação. 
Sua missão é o desenvolvimento da profissão contábil em nível internacional, promovendo a harmonização de padrões que possibilitem a prestação de serviços de alta qualidade visando ao interesse social.

É composta pelos comitês de Educação, Ética, Contabilidade Financeira e Gerencial, Tecnologia da Informação, Práticas Internacionais de Auditoria e Setor Governamental. O comitê que trata da discussão sobre as competências do contador é o de educação. Ele emite as Diretrizes Internacionais de Educação (IEG), as quais lançam os requerimentos essenciais para a educação de Contabilidade, visando à boa prática na educação contábil.

A IEG n ${ }^{\circ}$ 9, em questão, tem o objetivo de avaliar as necessidades de educação e experiências, abrangendo conhecimentos, capacidades, valores profissionais e os elementos do ensino da Contabilidade, bem como os ambientes institucionais e culturais das pessoas responsáveis pela formação dos contadores, recomendando estratégias para cumprir esses requisitos.

Essa diretriz apresenta uma meta, uma base para a educação e formação ao longo da vida, e discute sobre os conhecimentos, as competências e os valores profissionais que são essenciais para o desempenho profissional da Contabilidade.

\subsubsection{Conhecimentos}

Devem ser adquiridos antes da qualificação, enquanto o aluno prepara-se para exercer a profissão. Os conhecimentos previstos são: geral, organizacional e empresarial, tecnologia da informação, Contabilidade e correlacionado.

\subsection{Conhecimentos gerais}

É difícil pensar em conhecimentos gerais quando se refere à formação dos contadores do mundo todo, pois a realidade e as exigências em termos de educação geral variam de país a país, de programa a programa. Todavia, o que se espera é que parte da educação geral esteja focada no “[...] desenvolvimento de conhecimentos gerais, habilidades intelectuais, habilidades interpessoais e habilidades de comunicação, por meio de um amplo conjunto de disciplinas que proporciona aos estudantes uma instrução básica em artes, ciências e 
humanidades.”23 (IFAC, 1996, parágrafo 29).

\subsection{Conhecimento organizacional e de negócios}

Inclui economia, métodos quantitativos e estatística para negócios, comportamento organizacional, gerenciamento de operações, marketing e negócios internacionais.

\subsection{Conhecimento em tecnologia da informação}

É essencial o contador não somente usar e avaliar os sistemas como também participar do desenvolvimento e gerenciamento desses sistemas.

\subsection{Conhecimento contábil e áreas correlacionadas}

São os conhecimentos/experiências técnicos essenciais a uma carreira de sucesso como contador. Inclui Contabilidade Financeira, Contabilidade Gerencial, tributos, direito comercial, auditoria, administração financeira e ética profissional.

\subsubsection{Habilidades}

“[...] capacitam o contador a fazer uso bem-sucedido do conhecimento obtido através da educação. Elas geralmente não são adquiridas em cursos específicos, mas são frutos do efeito total do programa de educação e experiência profissional.”24 (IFAC, 1996, parágrafo 16).

As habilidades previstas são agrupadas em: intelectuais, interpessoais e de comunicação.

\subsection{Habilidades intelectuais}

Um contador profissional deve ser capaz de resolver problemas, tomar decisões e exercitar adequado julgamento em situações organizacionais complexas. Refere-se: à capacidade para consulta, pesquisa, pensamento lógico abstrato, raciocínio indutivo e dedutivo e análise

\footnotetext{
${ }^{23}$ “[...]development of general knowledge, intellectual skills, interpersonal skills, and communication skills through a broad range of subjects that provide students with a grounding in arts, sciences and humanities.”

24 "[...] enable the professional accountant to make successful use of the knowledge gained through education. They are not usually acquired from specific courses devoted to them but from the total effect of the educational program and professional experience."
} 
crítica; à habilidade em identificar e resolver problemas não estruturados em ambientes desconhecidos; à habilidade para selecionar e sinalizar prioridades considerando restrição de recursos e organizar trabalho para atender prazos estreitos; e à habilidade em se adaptar às mudanças.

\subsection{Habilidades interpessoais}

Trabalhar com outros para o bem comum da organização é também outra habilidade do contador. Os componentes são: a habilidade em trabalhar com outros em um processo consultivo, particularmente em grupos, para organizar e delegar tarefas, para motivar e desenvolver pessoas, para consultar e resolver conflitos e, no momento oportuno, liderar as equipes; a habilidade de interagir com pessoas diferentes intelectual e culturalmente; a habilidade de negociar soluções e acordos aceitáveis em situações profissionais; e a habilidade de trabalhar eficazmente em um ambiente multicultural.

\subsection{Habilidades de comunicação}

O contador deve estar apto para receber e transmitir informações, formar julgamentos fundamentados e tomar decisões. Os componentes são: a habilidade para apresentar, discutir e defender pontos de vista de forma eficiente, através de linguagem formal e informal, escrita e falada; a habilidade para ouvir e ler de forma eficiente, incluindo uma sensibilidade para diferenças culturais e de linguagem; e a habilidade para localizar, obter, organizar, evidenciar e usar informações de fontes humanas, impressas e eletrônicas.

Diante do que foi exposto, este trabalho teve por objetivo verificar, por meio de pesquisa empírica baseada em estudo de casos, se a implantação do ERP provocou mudanças na área de Contabilidade das empresas pesquisadas, em termos de: estrutura organizacional, atividades desenvolvidas e conhecimentos e habilidades exigidos para a execução dessas atividades.

Para subsidiar a análise dos dados coletados na pesquisa, a revisão da literatura foi elaborada revendo inicialmente algumas questões sobre os Sistemas Empresariais Integrados (ERP) e sobre o sistema R/3. Como este sistema geralmente demanda alterações nos processos e na forma de organizar a empresa, também foram apresentadas algumas questões sobre mudança 
organizacional, estrutura das organizações, desenho organizacional e estrutura de cargos. Finalmente, como o objeto de análise é a área contábil das organizações, foram apresentadas algumas questões sobre o objetivo da Contabilidade, o SIC e as atividades desenvolvidas na área contábil das empresas e sobre as competências necessárias ao profissional para desempenhar tais atividades.

No próximo capítulo, encontra-se detalhada a metodologia da pesquisa. 



\section{METODOLOGIA DA PESQUISA}

\subsection{Delineamento da Pesquisa}

Elaborar o design de uma pesquisa é um processo que exige lógica e planejamento. É necessário pensar em todos os aspectos possíveis de serem visualizados antes mesmo de o projeto ter início. Partindo da problemática que deu origem à pesquisa, passando pela questão que guia todo o processo, faz-se necessário identificar de antemão a metodologia adequada para conduzir a investigação, bem como as técnicas de coleta de dados e a abordagem a ser utilizada para a análise desses dados.

O design da pesquisa faz a conexão dos paradigmas teóricos, estratégias de pesquisa e métodos para coleta de material (DENZIN; LINCOLN, 1994). Segundo esses autores, o design da pesquisa tem como foco a questão da pesquisa, o propósito do estudo, “[...] qual informação mais apropriadamente responderá questões específicas da pesquisa, e quais estratégias são mais efetivas para obtê-la.”25 (LECOMPTE et al apud DENZIN; LINCOLN, 1994, p. 14).

Neste estudo, conforme detalhado na introdução (capítulo 1), a problemática da pesquisa envolveu compreender algumas mudanças organizacionais ocorridas na área de Contabilidade de empresas que implementaram um sistema empresarial integrado (ERP).

Por conseguinte, a pesquisa buscou responder à seguinte pergunta: Como a implantação dos ERPs influencia os aspectos organizacionais da área de Contabilidade referentes à estrutura organizacional, às atividades desenvolvidas e aos conhecimentos e habilidades necessários para a execução das atividades?

Encontrar respostas a essa questão exigiu que o estudo fosse conduzido de forma a identificar as mudanças que ocorreram em cada empresa e interpretá-las considerando o contexto em que

\footnotetext{
${ }^{25}$ (...) what information most appropriately will answer specific research questions, and wich strategies are most effective for obtaining it."
} 
ocorreram, a percepção das pessoas envolvidas nas mudanças, a própria percepção do pesquisador sobre a realidade, além de buscar relacionar as descobertas às teorias já existentes no conhecimento científico. Dessa forma, o estudo se configura como qualitativo. Essa conclusão é possível tendo em vista a caracterização de pesquisa qualitativa discutida por alguns autores.

Para Denzin e Lincoln (1994, p. 2), pesquisa qualitativa refere-se a uma área de estudos que envolve abordagem interpretativa e naturalista, já que se dedica a entender o mundo através da percepção que as pessoas têm dele. Existe relação entre o pesquisador e o fenômeno pesquisado, e o contexto em que ocorre tal fenômeno também é importante para a pesquisa.

Bryman (1995, p. 137) cita alguns aspectos da pesquisa qualitativa que contribuem para a compreensão de sua natureza: forte ênfase na interpretação; a pesquisa permite um forte sentido de contexto; há ênfase no processo; geralmente a abordagem é pouco estruturada no início; normalmente utiliza diversas fontes de dados, como observação participante, entrevistas e documentos, que possibilita o cruzamento dos dados; permite apreender a concepção da realidade; existe proximidade entre o pesquisador e o fenômeno que está sendo investigado.

Babbie (2001) utiliza a expressão pesquisa de campo qualitativa e a define da seguinte maneira:

Em resumo, então, a pesquisa de campo oferece a vantagem de sondar a vida social em seu habitat natural. Embora algumas coisas possam ser estudadas adequadamente em questionários ou em laboratórios, outras não podem. E a observação direta no campo permite aos pesquisadores observar comunicações sutis e outros eventos que poderiam não ser previstos ou medidos de outro modo. ${ }^{26}$ (Ibid., p. 277).

Sob essa perspectiva, os dados são coletados diretamente pelo pesquisador, através do contato com a situação pesquisada e com as pessoas envolvidas, e uso de técnicas específicas como

\footnotetext{
${ }^{26}$ In summary, then, field research offers the advantage of probing social life in its natural habitat. Although some things can be studied adequately in questionnaires or in the laboratory, others cannot. And direct observation in the field lets researchers observe subtle communications and other events that might not be anticipated or measured otherwise.
} 
entrevista, observação etc. A preocupação maior é interpretar os fenômenos do dia-a-dia sob o ponto de vista dos participantes.

Após caracterizar essa pesquisa como qualitativa, é importante discutir um outro aspecto: seu caráter exploratório. Alguns autores consultados (YIN, 2001; BABBIE, 2001; SELLTIZ, 1987) distinguem as pesquisas quanto aos propósitos do estudo e apresentam três classificações: estudos exploratórios, estudos descritivos e estudos explanatórios. O entendimento desses autores convergem para algumas características em cada um dos tipos citados:

a) Estudos exploratórios - esse tipo de estudo é conduzido quando o pesquisador pretende investigar uma nova variável, um fenômeno ainda não estudado ou uma nova abordagem ainda não explorada;

b) Estudos descritivos - esse tipo de estudo é conduzido quando o pesquisador pretende descrever uma situação ou fenômeno que observou;

c) Estudos explanatórios - esse tipo de estudo é conduzido quando o pesquisador pretende explicar os fenômenos, estabelecer relações causais entre as variáveis observadas.

Embora seja importante estabelecer essa diferenciação entre os propósitos de pesquisa, Babbie (2001, p. 94) lembra que a maioria dos estudos terá elementos dos três tipos citados, ou seja, um mesmo estudo pode ser inicialmente de caráter exploratório, por referir-se a uma problemática nova, depois passar por uma fase mais estruturada e ser descritivo para, num terceiro momento, ter condições de ser explanatório.

A pesquisa aqui desenvolvida teve como predominante o aspecto exploratório, porque buscou estudar variáveis que ainda não foram investigadas no nível de detalhes proposto, sendo, portanto, o primeiro estudo no universo pesquisado com essas características. Além disso, apresentou, num segundo momento, o aspecto descritivo, porque descreveu as atividades realizadas na área de Contabilidade das empresas pesquisadas, os conhecimentos e habilidades demandados por estas atividades e as alterações que ocorreram nesses três fatores, tendo em vista a implementação do ERP. Não foi intenção desse estudo o aprofundamento sobre as relações de causalidade das mudanças ocorridas na área de Contabilidade das empresas pesquisadas, o que demandaria a investigação de outras variáveis que poderiam influenciar nas mudanças. Antes, procurou-se verificar as mudanças ocorridas e indícios que 
demonstrassem que elas possam ou não ter sido provocadas pela implementação do ERP.

Para desenvolver essa pesquisa, foi preciso identificar qual estratégia seria a mais adequada. Estratégia de pesquisa pode ser entendida como:

[...] uma gama de habilidades, hipóteses e práticas que os pesquisadores empregam quando se movem do seu paradigma para o mundo empírico. Estratégias de pesquisa colocam os paradigmas de interpretação em movimento. Ao mesmo tempo, estratégias de pesquisa conectam o pesquisador aos métodos específicos de coleta e análise de material empírico. ${ }^{27}$ (DENZIN; LINCOLN, 1994, p. 14).

É importante salientar que os autores consultados usam como sinônimos métodos de pesquisa, práticas de pesquisa e estratégias de pesquisa.

Yin (2001, p. 19) comenta que a definição da estratégia mais adequada depende basicamente de três condições: o tipo de questão da pesquisa, o controle que o pesquisador tem sobre os eventos comportamentais efetivos e o foco em fenômenos históricos, em oposição a fenômenos contemporâneos.

Diversos métodos de pesquisa podem ser utilizados para desenvolver uma pesquisa qualitativa, como por exemplo, etnografia, observação participante, método histórico, método biográfico, pesquisa ação, estudo de caso, entre outros.

Após analisar as diversas estratégias propostas na literatura consultada, verificou-se que a mais adequada para este estudo é a metodologia estudo de caso, visto que ela permite conhecer profundamente um objeto de estudo, em seu sentido amplo, multidimensional, considerando o contexto onde está inserido. Este “mergulho” profundo na unidade estudada, através da análise sistêmica, permite que se conheça todas as suas dimensões, suas especificidades. Embora seja possível estudar vários casos simultaneamente, prática denominada estudo de casos múltiplos, em cada situação a pesquisa está concentrada num caso particular, o que o torna único.

Na visão de Yin (2001, p. 32), “Um estudo de caso é uma investigação empírica que investiga

\footnotetext{
${ }^{27}$ [...] a bundle of skills, assumptions, and practices that researchers employ as they move from their paradigm to the empirical world. Strategies of inquiry put paradigms of interpretation into motion. At the same time, strategies of inquiry connect the researcher to specific methods of collecting and analyzing empirical materials.
} 
um fenômeno contemporâneo dentro de seu contexto da vida real, especialmente quando os limites entre o fenômeno e o contexto não estão claramente definidos.”

É importante salientar que a estratégia estudo de casos não pode ser confundida com pesquisa qualitativa, visto que ela também pode ser utilizada em pesquisa quantitativa ou ainda em pesquisa que combine as duas abordagens.

\subsection{Planejamento do Estudo de Casos}

Neste estudo, foi utilizada a proposta de Yin (2001) para planejamento de estudo de caso. Segundo esse autor, os componentes de um projeto de pesquisa que utilize a estratégia estudo de caso são: questões de um estudo, suas proposições (se houver), sua(s) unidade(s) de análise, a lógica que une os dados às proposições e os critérios para se interpretar as descobertas.

\subsubsection{Componentes do projeto de pesquisa}

\subsubsection{Questão da pesquisa}

Como a implantação dos ERP influencia os aspectos organizacionais da área de Contabilidade referentes à estrutura organizacional, às atividades desenvolvidas e aos conhecimentos e habilidades necessários para a execução das atividades?

\subsubsection{Proposições}

Conforme comentado em detalhes anteriormente, este estudo se configura como predominantemente exploratório. Tendo em vista que as proposições deveriam embasar-se em conhecimentos previamente adquiridos, geralmente não é possível defini-las para pesquisas dessa natureza.

Todavia, como sugere Yin (2001, p.42), seria adequado apresentar uma finalidade e os 
critérios utilizados para verificar se a exploração foi bem sucedida.

Dessa forma, a finalidade deste estudo foi compreender as mudanças que ocorreram na Contabilidade em termos de estrutura organizacional, atividades desenvolvidas e conhecimentos e habilidades necessários à execução das atividades após a implementação de um ERP. Essa finalidade foi alcançada após:

- $\quad$ a identificação das mudanças ocorridas;

- a análise destas mudanças e seu relacionamento com a implementação do ERP, tendo como base teórica os conhecimentos obtidos na revisão da literatura;

- $\quad$ a elaboração de um relatório evidenciando as mudanças e a análise efetuada.

\subsubsection{Unidade de análise}

Na concepção de Yin (2001), a determinação da unidade de análise está relacionada com a questão da pesquisa proposta, ou seja, uma questão de pesquisa bem formulada, conseqüentemente, apontará para uma unidade de análise específica. Caso isso não ocorra, é possível que a questão esteja muito ampla, o que poderá acarretar problemas na condução do estudo.

Segundo Babbie (2001, p. 95), “Unidades de análise em um estudo são geralmente as unidades de observação. [...] unidades de análise, então, são aquilo que nós examinamos a fim de criar descrições sumárias de tais unidades e explicar diferenças entre elas.”²8

Este estudo tem como unidade de análise a área de Contabilidade das empresas pesquisadas e, nesta, os aspectos de interesse são: estrutura organizacional, atividades desenvolvidas e conhecimentos e habilidades necessários para a execução das atividades.

\footnotetext{
${ }^{28}$ Units of analysis in a study are usually also the units of observation [...]units of analysis, then, are those things we examine in order to create summary descriptions of all such units and to explain differences among them.
} 


\subsubsection{Critérios para análise dos dados}

A análise das mudanças identificadas e seu relacionamento com a implementação do ERP foi desenvolvida confrontando os dados coletados com o referencial teórico sobre ERP, mudança organizacional e Contabilidade, apresentado no capítulo 2. A importância do referencial teórico é comentada por Morse (1994, p. 221):

[...] na pesquisa qualitativa a teoria é usada para focar a pesquisa e dar a ela parâmetros para comparação e facilitar o desenvolvimento de resultados teóricos ou conceituais. A teoria ou conceito pode ser considerado mais como um modelo conceitual com o qual comparar e contrastar resultados, do que usá-la como categorias prévias nas quais forçar a análise. ${ }^{29}$

Nessa análise, em se tratando de pesquisa qualitativa, foram consideradas também as percepções das pessoas envolvidas nas mudanças, a própria percepção da pesquisadora sobre a realidade e o contexto envolvido.

\subsubsection{Definição dos casos}

Uma pesquisa que utiliza a estratégia estudo de caso pode ser desenvolvida a partir da análise de apenas um caso (caso único) ou de vários casos (múltiplos casos).

Dentre as razões que justificam a opção por múltiplos casos, Herriot e Firestone (1983) apud Yin (2001, p. 68) entendem que: “As provas resultantes de casos múltiplos são consideradas mais convincentes, e o estudo global é visto, por conseguinte, como sendo mais robusto.”

Na visão de Bryman (1995, p. 171), ao incluir mais de um caso na pesquisa “A generalização da pesquisa pode ser intensificada e comparações permitem que aspectos especiais dos casos sejam identificados mais facilmente.”30

Tendo em vista o caráter predominantemente exploratório deste trabalho e considerando que dados coletados em diferentes organizações proporcionam uma análise mais rica da realidade

\footnotetext{
${ }^{29}[. .$.$] in qualitative inquiry the theory is used to focus the inquiry and give it boundaries for comparison in$ facilitating the development of the theoretical or conceptual outcomes. The theory or concept of interest at best may be considered a conceptual template with which to compare and contrast results, rather than to use as a priori categories into which to force the analysis.

30 “ The generalizability of the research may be enhanced, and comparisons allow the special features of cases to be identified much more readily."
} 
pesquisada, possibilitando considerar evidências de diferentes contextos, foi definido para este trabalho a abordagem de casos múltiplos.

Devido à extensão do estudo, visto que aprofunda a investigação sobre as influências do ERP na área de Contabilidade, 3 (três) casos foram estudados. Um número maior de casos, embora mais representativo, tornaria o estudo inviável, pois demandaria mais tempo que o disponível para esta pesquisa. Basicamente, dois critérios foram utilizados para selecionar os casos que fazem parte deste estudo:

a) Empresas que possuam o módulo financeiro do R/3, desenvolvido pela empresa SAP.

b) Empresas do estado do Paraná, principalmente as situadas nas proximidades da cidade de Maringá, onde reside a pesquisadora.

\subsubsection{Protocolo da pesquisa}

A elaboração do protocolo contribui fortemente para aumentar a confiabilidade da pesquisa. Yin (2001, p. 89) comenta que:

\footnotetext{
O protocolo contém o instrumento, mas também contém os procedimentos e as regras gerais que deveriam ser seguidas ao se utilizar o instrumento. É desejável se possuir um protocolo para o estudo de caso em qualquer circunstância, mas é essencial se você estiver utilizando um projeto de casos múltiplos.
}

O objetivo deste protocolo foi orientar a coleta de dados, análise individual e análise cruzada dos casos estudados.

\subsubsection{Contato com a empresa}

Após a definição das empresas que seriam visitadas, coletou-se informações sobre as mesmas através da internet, com o intuito de conhecer melhor cada organização. O primeiro contato foi por telefone, com a pessoa responsável pela Contabilidade (gerente ou diretor), para solicitar uma visita às empresas. Na primeira visita, foram detalhados os objetivos e os procedimentos da pesquisa, solicitando a colaboração da empresa e entregando a carta de apresentação, evidenciada no Quadro 3: 
São Paulo, 03 de outubro de 2003.

Ao

Sr. Fulano de Tal

Empresa X

Prezado Senhor,

Apresentamos a aluna Lílian Moreira de Alvarenga Assolari, que se dirige a V.Sas. com a finalidade de obter informações para o Programa de Pesquisa que vem sendo desenvolvido sob o título "Influências dos Sistemas Empresariais Integrados (ERP) na Contabilidade - Impactos na Estrutura Organizacional, nas Atividades e nos Conhecimentos e Habilidades do Contador".

A pesquisa em questão está sendo desenvolvida pela pesquisadora como parte integrante do Programa de Mestrado, junto ao TECSI - Laboratório de Tecnologia de Informação, do Departamento de Contabilidade e Atuária da Faculdade de Economia, Administração e Contabilidade da Universidade de São Paulo e tem caráter essencialmente acadêmico.

As questões procuram obter informações sobre as mudanças que a implantação do ERP provocou na área de Contabilidade em termos de: estrutura organizacional, atividades desenvolvidas e conhecimentos e habilidades exigidos para a execução dessas atividades. Tais perguntas tencionam descrever uma situação real, não havendo, portanto, respostas consideradas melhores ou tecnicamente mais corretas.

Apesar da inexistência de questões que quebrem o sigilo necessário aos negócios ou comprometam o pesquisado de alguma maneira, os resultados das entrevistas são estritamente confidenciais e somente serão divulgados com consentimento prévio de V.Sas.

Agradecemos a colaboração dos entrevistados lembrando que suas informações estarão propiciando o estudo dos fenômenos e das situações reais das organizações brasileiras, contribuindo para o desenvolvimento científico de nosso país. O relatório final, quando concluído, estará à disposição de V.Sas.

Antecipadamente, agradecemos sua valiosa participação, permanecendo à disposição para quaisquer esclarecimentos adicionais.

Dados da Pesquisadora: Lílian Moreira de Alvarenga Assolari

Telefone: (44) 227-7340e-mail: lialvarenga@hotmail.com

Atenciosamente,

Prof. Dr. Edson Luiz Riccio

Orientador - TECSI - FEA/USP

Email: elriccio@usp.br

Av. Prof. Luciano Gualberto, 908 FEA 3

05508-900 Cid. Universitária São Paulo/SP

Após a conversa de apresentação e obtida a autorização para a coleta de dados, as entrevistas tiveram início. As seguintes pessoas foram entrevistadas:

a) o responsável pela Contabilidade, pois ele tem a visão geral de todos os processos e atividades e das alterações destes; 
b) a pessoa da área de Recursos Humanos responsável pela área de cargos e salários, para obter detalhes sobre a política de cargos e as mudanças na estrutura da empresa;

c) a pessoa da área de Informática responsável pela implementação do sistema R/3, para obter detalhes sobre esse projeto;

d) todos os funcionários da Contabilidade, para obter a descrição detalhada das atividades.

Eventualmente, outras pessoas foram entrevistadas, dependendo da necessidade verificada durante a coleta de dados. As entrevistas foram realizadas tendo como roteiro inicial os questionários constantes nos apêndices 1, 2, 3 e 4. É importante salientar que este roteiro não se manteve inflexível, permitindo que outras questões fossem formuladas, ou que as questões previstas fossem detalhadas, conforme a necessidade identificada pela pesquisadora durante as entrevistas.

A coleta de dados foi executada nos seguintes períodos:

- $\quad$ Empresa piloto: 18/08 a 21/08/2003

- $\quad$ Empresa 1 (caso 1):08/09 a 11/09/2003

- $\quad$ Empresa 2 (caso 2):13/09 a 19/09/2003

- $\quad$ Empresa 3 (caso 3):14/11 a 21/11/2003

\subsubsection{Coleta de dados}

Yin (2001) chama a atenção sobre a necessidade de trabalhar com várias fontes de evidências na pesquisa de estudo de casos. O uso de várias fontes possibilita confrontar os dados obtidos com cada uma, auxiliando na obtenção de resultados mais confiáveis e contribuindo para a validação da pesquisa.

Compartilhando a mesma opinião, Bryman (1995, p. 140) comenta que o uso de várias fontes de dados em uma pesquisa traz como benefícios a coleta de dados sobre questões que não podem ser diretamente observadas, a confrontação de informações obtidas de diferentes fontes e a validação da interpretação da pesquisadora sobre o tema. 
Neste trabalho, foram coletados dados através de entrevistas, documentos e observação da pesquisadora. Na execução das entrevistas, foi utilizado o gravador para registrar os dados coletados. Os seguintes documentos básicos foram solicitados: a descrição de cargos da área de Contabilidade, organograma da empresa e da área de Contabilidade, documentos sobre a missão/filosofia/objetivos da empresa, caso a empresa dispusesse.

Inicialmente, foi executada a coleta de dados em uma empresa piloto, para verificar a validade dos questionários e a viabilidade quanto aos demais procedimentos previstos no protocolo. Após essa coleta de dados, os questionários foram revistos e adequados. Quanto aos demais procedimentos, foram mantidos.

\subsubsection{Referencial de análise}

O capítulo 2 foi desenvolvido com a finalidade de proporcionar uma sustentação teórica ao estudo, bem como auxiliar o leitor a familiarizar-se com os assuntos relacionados à pesquisa, permitindo um melhor entendimento dos resultados obtidos. Nesse sentido, o capítulo apresenta tanto os conceitos fundamentais que sustentam a análise dos dados quanto as informações adicionais, mais detalhadas, de forma a contextualizar cada tema de interesse da pesquisa.

Entretanto, com o intuito de facilitar o relacionamento dos resultados da pesquisa com a teoria consultada, serão apresentados os tópicos mais utilizados na análise dos resultados e na conclusão. Atendendo à seqüência de temas do capítulo 2, inicialmente serão apresentados os tópicos de interesse relacionados ao ERP, posteriormente os relacionados à mudança organizacional e estrutura organizacional e, por fim, aqueles relacionados à Contabilidade.

\subsection{Sistemas empresariais integrados}

A análise dos dados foi conduzida tendo por base teórica os seguintes tópicos:

a) vantagens e problemas associados ao ERP (RICCIO, 2001; DAVENPORT, 1998; HEDMAN; BORELL, 2002; HAMILTON, 2004a; 2004b; SOUZA; ZWICKER, 1999);

b) riscos associados ao ERP (HALL, James, 2001);

c) fatores críticos de sucesso associados ao ERP (BANCROFT et al, 1997). 
Buscou-se verificar se a realidade apresentada pelas empresas estava em consonância com esses itens citados acima, já que mudanças na área de Contabilidade podem ou não ter ocorrido nas empresas pesquisadas motivadas pela inobservância de um ou mais destes itens, em detrimento do potencial de mudança inerente ao ERP.

\subsection{Mudança organizacional e tecnologia da informação}

A análise dos dados foi conduzida tendo por base teórica os seguintes tópicos:

a) a organização é formada por diversos elementos (estruturas, processos, tecnologia e pessoas/valores) que interagem entre si, de maneira que uma mudança em qualquer dos elementos pode provocar alterações nos demais (GALLIERS, 1998);

b) a implementação de novos sistemas tem sido usada como oportunidade para fazer uma substancial mudança organizacional e operacional. Freqüentemente, o fluxo de informações e procedimentos é completamente repensado e cargos reconstituídos antes de um sistema de informação ser implementado (TURNER, 1998);

c) a tecnologia de informação avançada, por si só, é incapaz de garantir vantagens de desempenho significativas, como aquelas decorrentes da inovação tecnológica acompanhadas de uma reorganização do sistema de trabalho (WALTON, 1993);

d) não existe um modelo ótimo para o desenho organizacional, mas sim um desenho mais adequado para cada situação, tendo em vista diversos fatores que influenciam a organização - teorias contingenciais (ROBBINS, 1990);

e) a estrutura organizacional está relacionada à divisão de tarefas, reagrupamento das tarefas divididas, níveis hierárquicos, localização geográfica das unidades da empresa, grau de controle do comportamento dos funcionários através de regras e procedimentos, e definição de autoridade para a tomada de decisão. Todos esses itens se referem aos componentes da estrutura organizacional que são complexidade, formalização e centralização (ROBBINS, 1990);

f) os cargos comportam o agrupamento das atividades e a especificação dos conhecimentos e habilidades necessários ao desempenho das mesmas (ZIMPECK, 1992; PONTES, 2000). 


\subsection{Sistema de informações contábeis}

A análise dos dados foi conduzida tendo por base teórica os seguintes tópicos:

a) a Contabilidade é um sistema de informação capaz de fornecer informações para usuários externos, atendendo às exigências da legislação pertinente, e também para usuários internos, nesse caso sem ter que atender a nenhuma legislação específica, mas sim às necessidades dos usuários (IUDÍCIBUS et al, 1995; ATKINSON et al, 2000);

b) essas duas vertentes são denominadas Contabilidade Financeira e Contabilidade Gerencial e não são excludentes, ao contrário, são complementares, de modo que a Contabilidade Gerencial utiliza os dados da Contabilidade Financeira além de outros dados adicionais (ATKINSON et al, 2000);

c) uma das principais características da Contabilidade é ser um sistema consolidador, visto que o sistema é estruturado de tal maneira que todos os dados registrados na empresa convergem para o processamento contábil (RICCIO, 1989; WILKINSON, 2000);

d) o Sistema de informações contábeis pode ser considerado sob uma abordagem restrita ou sob uma abordagem ampliada. (MOSCOVE et al, 2002; RICCIO, 1989; HALL, James, 2001). A forma como o ERP é estruturado potencializa a inserção da Contabilidade sob a abordagem ampliada;

e) a IEG $n^{\circ} 9$ propõe uma estrutura que inclui os conhecimentos e habilidades que o profissional da Contabilidade deve apresentar no exercício de suas funções. Esse documento está organizado da seguinte maneira: conhecimentos gerais, conhecimento organizacional e de negócios, conhecimento em tecnologia da informação, conhecimento contábil e áreas correlacionadas, habilidades intelectuais, habilidades interpessoais e habilidades de comunicação.

\subsubsection{Relatório do estudo de casos}

Encontra-se, no capítulo 4, a apresentação dos dados e a análise individual do caso 1 e do caso 2. Para tanto, foi necessário elaborar as descrições dos cargos com comentários sobre as mudanças verificadas nas atividades e nos conhecimentos e habilidades (apêndice 5). Encontram-se, no item 4.3, algumas informações sobre o caso 3 com a explicação dos motivos pelos quais não foram utilizados, nesta pesquisa, os dados coletados junto à Empresa 3. 
Posteriormente, no item 4.4, constam os resultados de outras pesquisas já publicadas, as quais, embora não tenham o mesmo objetivo que este estudo, apresentam alguns resultados que podem ser comparados com os resultados desta pesquisa, guardadas algumas restrições. Finalmente, o item 4.5 traz a análise comparativa entre o caso 1, o caso 2 e outros resultados de pesquisas já publicadas.

\subsection{Limitações da Pesquisa}

Quanto aos limites da pesquisa qualitativa, as principais críticas a essa metodologia são a falta de neutralidade e a subjetividade, já que o pesquisador está envolvido no processo e interpreta os fenômenos através dos olhos dos indivíduos que estão sendo observados, além de também ser influenciado por sua percepção pessoal. Entretanto, como Demo (1995, p. 250) destaca:

A subjetividade faz parte da realidade social e não pode ser acolhida metodologicamente como fator perturbante, que não deveria existir. O homem é ator, não consegue observar-se neutramente e estabelece com sua sociedade uma relação muito mais complexa que a formal-lógica da ciência clássica.

Para os defensores da abordagem qualitativa, é muito pior ignorar as peculiaridades existentes no campo das ciências humanas e sociais, e simplesmente utilizar um padrão único de pesquisa centrado no positivismo.

Juntamente com a questão da subjetividade, outra limitação apontada pelos críticos da pesquisa qualitativa é a generalização dos resultados. Sobre esse assunto, Yin (2001, p.29) afirma que:

Os estudos de casos, da mesma forma que os experimentos, são generalizáveis a proposições teóricas, e não a populações ou universos. Nesse sentido, o estudo de caso, como o experimento, não representa uma 'amostragem', e o objetivo do pesquisador é expandir e generalizar teorias (generalização analítica) e não enumerar freqüências (generalização estatística).

Neste estudo, procurou-se minimizar os efeitos da subjetividade por meio da coleta de dados de diversas fontes e por meio da sustentação da análise numa estrutura prévia fornecida pela fundamentação teórica. Sobre a generalização dos resultados, é importante observar as seguintes restrições: 
- $\quad$ foco da pesquisa;

- fundamentação teórica adotada;

- $\quad$ particularidade dos casos estudados.

Sendo assim, não é adequado generalizar os resultados obtidos para outras empresas. Todavia, tais resultados podem ser utilizados como parâmetros para pesquisas futuras e para empresas que se interessem em analisar as mudanças ocorridas em sua área de Contabilidade. 


\section{APRESENTAÇÃO E ANÁLISE DOS RESULTADOS}

\subsection{Caso 1 - Empresa 1}

\subsubsection{Contextualização}

A Empresa 1 é uma companhia aberta do ramo de industrialização e comercialização de café solúvel e derivados que atua no mercado interno e externo. Foi fundada em 1967 e é controlada por um grupo japonês. Sua sede fica na região norte do Paraná, possui cinco coligadas, sendo quatro no Brasil e uma na Inglaterra. Quando a coleta de dados desta pesquisa foi realizada, apresentava faturamento anual de aproximadamente $\mathrm{R} \$ 65$ milhões (sessenta e cinco milhões de reais).

No ano de 2003, quando os dados para este estudo foram coletados, uma das coligadas foi incorporada à Empresa 1 e é mantida como um segmento separado, denominado mercado interno. Essa coligada também utilizava o sistema R/3 da SAP.

Nesse mesmo período, estava sendo promovida a revisão da estrutura organizacional da Empresa 1, inclusive a revisão da estrutura de cargos. Estavam sendo discutidas questões referentes aos níveis hierárquicos, responsabilidades, autoridade em cada nível, amplitude dos cargos e, por conseqüência, estrutura dos cargos. Posteriormente, a empresa contrataria uma consultoria para implementar um plano de cargos e salários. Essa decisão atendeu a um projeto de crescimento da empresa estabelecido no ano de 2000.

Quanto aos recursos humanos, a Empresa 1 tem por política dar oportunidade aos funcionários para ocuparem vagas disponíveis, promovendo transferências internas.

É importante ressaltar que algumas das empresas coligadas têm a Contabilidade executada no mesmo espaço físico que a Contabilidade Financeira da Empresa 1, inclusive sob a coordenação do mesmo contador. A descrição de cargos (apêndice 5) detalha as atividades realizadas na Contabilidade relacionadas a essas coligadas. 


\subsubsection{Informações gerais sobre a implementação do $R / 3$}

Como o sistema existente na empresa não mais atendia à demanda por informações e não era viável desenvolver internamente um software, decidiu-se pela aquisição de um sistema que proporcionasse um ambiente integrado.

O estudo foi iniciado em 1996 com a análise de banco de dados, mas não foi bem sucedido. Em 1998, a decisão por ERP foi tomada e começou o processo de seleção da consultoria e do software, que culminou com a implementação do R/3 no ano seguinte.

A implementação do sistema ocorreu no período de março a novembro do ano de 1999. Na época da coleta dos dados, a empresa utilizava a versão 4.0, mas estava aguardando a atualização para 6.0.

Os módulos implementados foram: FI, CO, SD, PP, MM. A implementação foi por big bang e não gerou grandes problemas. No processo de customização, não foram feitas muitas alterações da versão standard (padrão) do R/3, especialmente nos módulos FI e CO que são foco deste estudo. Nestes módulos, as principais alterações foram os ajustes necessários para atender à legislação.

Por decisão da diretoria da empresa, a revisão e alteração dos processos existentes (reengenharia) não foram feitas, e os processos permaneceram como estavam. A participação do contador em todo o processo de implementação foi ativa e, segundo ele, “[...] não teve dificuldade, pois as pessoas das diversas áreas se conhecem há muito tempo e já desenvolveram muitos projetos juntos.”

\subsubsection{Estrutura organizacional}

A Empresa 1 tem sua estrutura organizacional formada por quatro níveis hierárquicos: diretoria, gerência, chefia e operacional.

De forma geral, a empresa não procedeu à revisão da sua estrutura organizacional para a implementação do R/3, uma vez que a Diretoria julgava não ser necessário. Essa revisão ocorreu somente após quatro anos da implementação do sistema, mais por motivos 
estratégicos do que pelos relacionados ao R/3. Entretanto, algumas alterações na ocasião da implementação ocorreram, e são comentadas na seqüência.

Com a implementação do sistema R/3, foi criada a área de Controladoria para desenvolver algumas atividades já existentes nas áreas de planejamento e Contabilidade. Estas foram centralizadas e realizadas através do módulo CO.

Com essa alteração, a área de Contabilidade (Contabilidade Financeira) e a área de Controladoria (Contabilidade Gerencial) ficaram subordinadas à Gerência de Auditoria e Controladoria, a qual faz parte da Diretoria de Controladoria. A Figura 6 apresenta o organograma que ilustra essa organização:

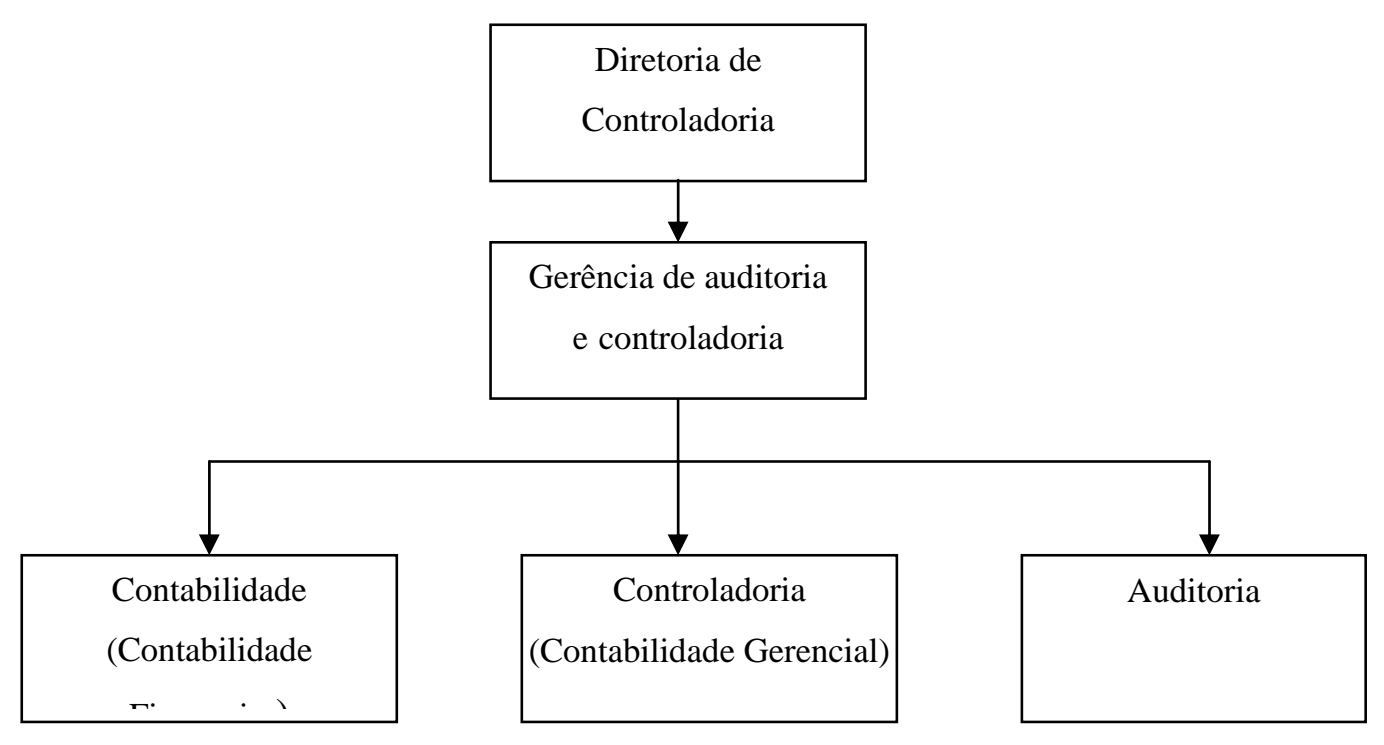

Figura 6 - Estrutura Organizacional Ligada à Contabilidade

Após a alteração, a Contabilidade Financeira deixou de realizar as atividades referentes a custos e a área de planejamento deixou de realizar as atividades referentes à elaboração de orçamentos, de análise de desempenho e de relatórios gerenciais em geral. Segundo um dos entrevistados, que atua na Controladoria, “[...] dentro do processo do R/3, o CO deveria estar dentro da Contabilidade, mas a diretoria deliberou que ficasse fora e por isto ficou junto à auditoria e à área de planejamento. Todo o processo de planejamento ficou aqui.”

Ressalta-se que, além de subordinadas à Diretoria de Controladoria, as pessoas que atuam na área de Controladoria também estão, informalmente, subordinadas à Diretoria de 
Planejamento, que foi mantida. Isso porque a atividade de orçamento é de responsabilidade de ambas as diretorias.

Quanto aos cargos, não houve alteração nas nomenclaturas. Todavia, as nomenclaturas de alguns cargos, que foram informadas pelos seus ocupantes, são diferentes daquelas constantes nos documentos da empresa. Ao que parece existe uma estrutura informal, que ainda não foi implementada. Possivelmente, o trabalho de revisão dos cargos e implementação do plano de cargos e salários solucionará essa questão. As descrições dos cargos constantes no apêndice 5 evidenciam o nome de cada cargo de acordo com os documentos da empresa e de acordo com os entrevistados.

O número de funcionários da área de Contabilidade Financeira, que era de dezessete pessoas, não foi alterado. Entretanto, foram identificadas alterações dos ocupantes de alguns cargos. Dois funcionários foram transferidos para o setor chamado 'Pool de Recebimentos', onde as atividades de recebimento das mercadorias adquiridas e de inserção dos dados referentes a essas aquisições são realizadas. Essa necessidade ocorreu porque os procedimentos de entrada ficaram mais detalhados e houve necessidade de pessoas com conhecimento contábil. Foi promovido um remanejamento interno na área de Contabilidade para a ocupação dessas duas vagas e foram contratados dois estagiários, mantendo o contingente de dezessete pessoas. $\mathrm{O}$ contador afirmou que:

não houve alteração no número de funcionários porque antes do R/3 já tinha um sistema que integrava algumas áreas com a Contabilidade. Já havia a cultura de entrada descentralizada e também a quantidade de funcionários necessária. O sistema anterior ao R/3 já possuía integração dessa atividade com a Contabilidade.

O contador mencionou sistema integrado, mas, segundo a pessoa responsável pela área de informática, o que existia era uma grande 'amarração' de sistemas, com necessidade de duplicação de dados, diferentemente do que acontece com um ERP.

Embora acreditasse que seria necessário colocar pessoas da Contabilidade para trabalhar 'nas pontas’, ou seja, nas diversas áreas da empresa onde as entradas de dados são realizadas, o contador comentou que não havia disponibilidade de pessoal para isso. 


\subsubsection{Atividades}

\subsubsection{Contabilidade financeira}

Na opinião do contador, "Não mudou o tipo de atividade desenvolvida e sim o jeito de trabalhar.” Isso porque, como comentado há pouco, na área de Contabilidade Financeira já havia descentralização dos registros contábeis e integração de sistema.

Também os funcionários afirmaram que o R/3 os auxiliou na execução de suas atividades, embora tenha existido uma dificuldade inicial para aprender a utilizar o sistema. Um dos entrevistados, quando questionado sobre as mudanças nas atividades, informou que: "Não mudou após o R/3, o mais difícil foi aprender a utilizá-lo.” Outro funcionário comentou: “O R/3 como foi apresentado parecia um bicho de sete cabeças e já vi que não é. É uma ferramenta muito fácil e ágil. Você precisa de informação, é só entrar. Ele veio para simplificar a vida da gente.”

Algumas atividades como as relacionadas a arquivo magnético, elaboração de cartas de correção, levantamento de documentos, verificação de lançamentos, entre outras, foram agilizadas com a implementação do R/3. Na opinião de um dos entrevistados: “[...] facilitou a movimentação de lançamentos contábeis. A facilidade do R/3 é que você pode rastrear. Antes, o lançamento ficava no sistema por três meses, depois ia para os livros. Hoje não, nós temos uma história.”

Com relação ao tempo de fechamento contábil e elaboração das demonstrações contábeis houve redução de sete dias para quatro dias.

Quanto às entradas de dados referentes à aquisição de mercadorias, parte destas aquisições eram registradas pelos funcionários do 'Pool de Recebimentos' e outra parte eram registradas na Contabilidade. A implementação do sistema centralizou todas essas entradas no setor 'Pool de Recebimentos'.

As atividades referentes ao controle do imobilizado passaram a ser mais valorizadas, visto que o R/3 permitiu melhor visualização dos bens existentes em cada setor e dos custos relacionados a estes bens. 
O sistema propiciou ainda uma maior percepção dos funcionários das outras áreas quanto aos reflexos que as atividades que eles executam provocam na Contabilidade. Entre outras conseqüências, tal percepção facilitou e intensificou o contato do contador com os demais gestores. Quanto às atividades desenvolvidas pelo contador, este comentou que embora a Diretoria o oriente quanto a desempenhar um papel mais estratégico, seu dia-a-dia exige que ele ainda se envolva muito com o operacional, dando suporte.

Outra mudança identificada consiste no aumento da atividade de conferência dos lançamentos contábeis: cerca de $80 \%$ a $90 \%$ dos registros são conferidos na Contabilidade através dos documentos originais. Conforme um dos entrevistados, “O problema é que dificultou o processo de entradas. Como as entradas são mais detalhadas, dá mais trabalho e os funcionários não entendem bem o R/3. Por outro lado, a Contabilidade não tem condições de colocar um especialista em cada setor.”

Erros freqüentes acontecem, os quais a Contabilidade precisa solucionar, pois algumas áreas, principalmente a área de vendas, continuam a inserir dados no sistema de forma incorreta. Nesse sentido, a implementação do R/3 dificultou a execução das atividades na Contabilidade, e como este sistema não permite alterações nos dados já registrados, tornou-se muito difícil e trabalhoso resolver os problemas gerados pelos erros cometidos. Para resolver esse problema, uma das estratégias adotadas foi intensificar a conferência dos lançamentos.

Outra estratégia foi manter uma atividade já realizada na área de Contabilidade anteriormente ao R/3 e que deveria ter sido descentralizada: o registro das diversas despesas, como por exemplo gastos gerais com diária de hotel, refeições etc.

Além dessas alterações, as pessoas da Contabilidade passaram a dar mais apoio para os demais funcionários da empresa quanto aos procedimentos do R/3. Antes da implementação, não havia tantas solicitações, uma vez que os erros de lançamentos identificados pelas pessoas da área de Contabilidade eram corrigidos por elas mesmas. Um dos entrevistados, que participou do projeto de implementação, comentou: “A diferença que eu vejo depois do R/3, é que além de tudo o que eu já fazia eu tenho que dar suporte a outras pessoas também. Como eu participei do projeto tenho a obrigação de dar suporte.” 
Por último, a elaboração dos custos dos produtos, que era desenvolvida na Contabilidade Financeira, foi transferida para a recém criada área de controladoria. No tópico a seguir, essa mudança será detalhada.

\subsubsection{Contabilidade gerencial}

A área de Controladoria concentra as atividades que são executadas com a utilização do módulo CO, as quais referem-se à Contabilidade Gerencial. Algumas mudanças nas atividades, provocadas pelo novo sistema também foram identificadas nesta área. Embora a área de Controladoria tenha sido criada após a implementação do sistema, as atividades ali desenvolvidas já existiam e faziam parte de outros setores.

As atividades relacionadas a custos eram desenvolvidas na Contabilidade Financeira e com a implementação do CO tudo que se referia a custos foi transferido para a Controladoria. Antes do R/3, eram calculados apenas custos por produtos e as informações disponíveis eram muito agregadas. O sistema utilizado para este cálculo não permitia muitas análises e as demais áreas que utilizavam essa informação não sabiam como o custo era formado.

Com o R/3, houve alterações na forma de cálculo de custos e no rateio dos custos indiretos. As apropriações são mais detalhadas e é possível proceder análises de diversas formas. Um dos entrevistados disse:

\footnotetext{
A gente passou a fechar custos, a entender melhor o processo de produção, a questão de relatório; mudou o estilo. A partir do momento que entrou o R/3 passamos a ter informações do custo em forma de média e não por item individual. Antes não tinha alocação de custos e hoje é muito boa, tudo é registrado e apropriado.
}

Essa mudança também provocou maior proximidade entre a área de controladoria e as demais áreas, pois o R/3 exigiu que se conhecessem os processos da empresa de forma mais profunda, especialmente os processos de produção.

Também houve alteração na forma de elaboração do orçamento, visto que, antes do R/3, alguns dados eram extraídos dos balancetes, vindos da Contabilidade, e outros eram extraídos de relatórios, vindos dos demais setores. Com o R/3, todos os dados estão disponíveis no 
sistema e podem ser consultados diariamente.

Outra mudança está relacionada ao cadastro de materiais. Por não conseguir reduzir os problemas freqüentes com o cadastro dos materiais no R/3, a Controladoria assumiu a responsabilidade por acompanhar a execução deste, na tentativa de evitar problemas posteriores. As pessoas que deveriam se preocupar em executar os registros adequadamente, para que o cadastro fique completo, não o fazem.

Uma atividade que antes da implementação do R/3 era menos freqüente é o suporte para informações aos demais funcionários da empresa. Segundo um dos entrevistados “Aumentou o trabalho, pois tudo o que as áreas têm dúvidas sobre o R/3 é na Controladoria que procuram informações."

Quanto às atividades relacionadas à elaboração de relatórios gerenciais, com o R/3, a informação fornecida pode ser mais detalhada, desagregada. O sistema facilitou as atividades e permitiu a elaboração de diversas formas de análise. Entretanto, é preciso utilizar o programa Excel para elaborar vários relatórios, cujos dados são extraídos do próprio R/3.

De forma geral, na Contabilidade Financeira e principalmente na Controladoria, anteriormente ao R/3 as atividades exigiam muito trabalho de digitação e com esse sistema o trabalho está focado mais em análise.

É importante observar que tanto os funcionários da área de Contabilidade Financeira quanto os da área de Controladoria necessitam utilizar freqüentemente o Excel para diversos controles e relatórios, utilizando dados extraídos do R/3. O lay-out dos relatórios disponibilizados por este sistema é mais complicado; por outro lado, para o contador "O bom do R/3 é que o sistema tem todas as informações e se precisar é só extrair.”

Embora a empresa esteja desempenhando todas as atividades necessárias e o sistema esteja auxiliando e facilitando a execução das mesmas, foi possível verificar que existe um certo descontentamento com relação aos benefícios proporcionados pelo R/3. A necessidade da empresa era a integração total de suas atividades e informações em tempo real. Quando o sistema foi apresentado à Diretoria, foi dito que se a empresa quisesse saber o balanço era só ‘apertar um botão’. Além disso, o software foi vendido como se fornecesse toda a informação 
que se quisesse. Isso gerou grande expectativa, mas na prática não foi bem assim.

Após quatro anos de utilização do sistema, a informação ainda não é em tempo real e também não há integração total, pois algumas informações, como por exemplo a apropriação da folha de pagamento, só são inseridas no final de cada mês, por ocasião do fechamento.

\subsubsection{Conhecimentos e habilidades}

Com relação aos conhecimentos e habilidades necessários para desempenhar as atividades previstas para a área de Contabilidade (incluindo a Controladoria), algumas alterações foram identificadas.

Quanto à necessidade de possuir graduação em Ciências Contábeis como grau de instrução, as opiniões ficaram divididas. Diversos entrevistados afirmaram que o R/3 exige que 0 funcionário tenha nível superior e outros afirmaram que a experiência na prática contábil é suficiente.

O conhecimento de línguas, especificamente o inglês, foi identificado como uma mudança provocada pelo R/3. Tanto para trabalhar com o sistema quanto para esclarecer dúvidas junto ao suporte técnico da empresa SAP, é preciso ter domínio desse idioma. Verificou-se que a maioria dos funcionários entrevistados estava fazendo um curso de inglês.

Com relação ao conhecimento em informática, a maior necessidade identificada foi o domínio do próprio R/3. Muitos funcionários não conhecem as possibilidades que este sistema oferece e, portanto, não exploram suas funcionalidades.

Além disso, segundo o contador, aumentou a necessidade de os funcionários serem mais críticos e analíticos. Isso porque, de um lado, reduziu um pouco a atividade de execução de lançamentos contábeis e digitação de dados e, por outro lado, aumentou o trabalho de conferência e análise, conforme apresentado anteriormente.

Por fim, a habilidade de relacionamento interpessoal foi reforçada com a implementação do R/3 já que foi preciso estar mais próximo das áreas, principalmente, da área de produção. 


\subsubsection{Análise}

Antes de proceder à análise, a fim de buscar a compreensão das alterações que aconteceram na Empresa 1, no tocante à estrutura organizacional, às atividades da área de Contabilidade e aos conhecimentos e habilidades necessários ao desenvolvimento dessas atividades, é importante compreender como a empresa procedeu no que se refere aos fatores críticos de sucesso. A relevância desse entendimento repousa no fato de que muitas das alterações na área de Contabilidade podem estar relacionadas a esses fatores críticos.

\subsubsection{Fatores críticos de sucesso (FCS)}

Na implementação de uma tecnologia de informação, é necessário que a equipe responsável pelo projeto tenha consciência de que estão sujeitos a diversos riscos e problemas, que podem comprometer o sucesso da implementação e que, para minimizar tais riscos, é fundamental observar os fatores críticos de sucesso que norteiam o projeto.

No caso da implementação de um ERP, Bancroft et al (1997) identificaram nove fatores críticos de sucesso e, relacionando-os à implementação do R/3 na Empresa 1, verifica-se que nem todos os fatores foram observados. Na seqüência, será comentado como a Empresa 1 procedeu quanto aos nove fatores críticos de sucesso mencionados.

\subsection{Compreender a cultura da empresa}

A equipe de projeto e os patrocinadores do projeto da Empresa 1 tinham consciência de que o R/3 era um sistema que demandaria muita dedicação e comprometimento dos funcionários, e que haveria dificuldades por causa da diversidade existente quanto à escolaridade e à experiência em informática. Também acreditavam que haveria algumas resistências, pois muitos funcionários já estavam trabalhando na empresa há muitos anos (15 anos, 20 anos e até mais) e, nesses casos, as pessoas tendem a adotar determinados hábitos e vícios em suas atividades. Com um sistema como o R/3, que exige mudanças, seria bem provável que resistências aconteceriam. Todavia, não houve um trabalho específico para superar essas dificuldades. Sendo assim, verifica-se que esse fator não foi atendido satisfatoriamente. 


\subsection{Iniciar a mudança dos processos de negócios antes da implementação}

A Diretoria da Empresa 1 decidiu não promover a revisão e alteração necessária nos seus processos. Não foi possível, entretanto, identificar os motivos de tal decisão. Poucas foram as alterações nos processos e elas aconteceram para atender à estrutura do R/3, mas foram casos isolados.

\subsection{Manter uma comunicação constante}

Não houve a preocupação, por parte dos dirigentes da empresa e da equipe de projeto da Empresa 1, em manter uma comunicação constante com os funcionários sobre o que era exatamente o projeto do R/3 e sobre o andamento do mesmo. Os funcionários obtinham informações através dos colegas que participavam da equipe do projeto. Portanto, esse fator não foi atendido, pois houve uma falha na comunicação.

\subsection{Garantir forte apoio dos executivos para o projeto}

A Diretoria estava convicta da necessidade de implementação do R/3 e apoiava totalmente o projeto. Todavia, não houve nenhuma iniciativa no sentido de ir aos funcionários e deixar explícito esse apoio, de forma a envolver todos no projeto.

\subsection{Possuir um gerente de projeto qualificado}

O gerente de projeto designado pela Empresa 1 é uma pessoa que demonstra ser bastante qualificada e que conhece bem a empresa e seus processos. Antes do R/3 ser implementado, essa pessoa fazia parte da equipe de assessoria, ligada à presidência. Ao que parece, esse fator crítico foi atendido.

\subsection{Escolher uma equipe de projeto balanceada}

Quanto aos experts em cada área de negócios, participaram da equipe de projeto as pessoas que realmente conheciam as atividades. Todavia, segundo informações, nem todos os membros da equipe tinham dedicação integral ao projeto. Quanto aos especialistas em 
informática, foi contratada uma consultoria parceira da SAP para ser o suporte técnico do projeto. Além disso, a Empresa 1 também possuía uma área de informática e os funcionários desta área também integraram a equipe de projeto como suporte técnico. Com essa composição, a equipe de projeto era balanceada.

\subsection{Escolher uma boa metodologia de projeto}

A Empresa 1 adotou a metodologia ASAP, desenvolvida pela empresa SAP, fornecedora do sistema R/3, com o intuito de padronizar os projetos de implementação dos seus softwares. Considerando que a empresa SAP é a líder no mercado nacional e mundial de ERP, conforme exposto no capítulo 2, item 2.1.1, e considerando também que todas as implementações do R/3 utilizam essa metodologia, é possível entender que a metodologia adotada era adequada para o projeto.

\subsection{Treinar os usuários}

A Empresa 1 promoveu treinamento aos funcionários procurando capacitá-los para utilizarem o R/3. Entretanto, houve falhas no dimensionamento das necessidades de treinamento e quando o sistema entrou em produção, os funcionários ainda não estavam preparados para utilizá-lo.

Com relação ao treinamento sobre Contabilidade, foi decidido designar duas pessoas de cada área para serem responsáveis pela inserção de dados no R/3 e, portanto, foram essas as pessoas que receberam treinamento. As demais aprenderam a manusear o R/3, no que diz respeito à Contabilidade, com a utilização desse sistema no dia-a-dia.

\subsection{Comprometer-se com a mudança}

A Empresa 1 não desenvolveu nenhuma iniciativa específica para promover a motivação da equipe do projeto, todavia, os funcionários informaram que a equipe demonstrou bastante dedicação durante todo o projeto. Ao que parece, a equipe de projeto estava comprometida com as mudanças. 


\subsubsection{Influência da implementação do ERP na estrutura organizacional}

Quando o R/3 foi implementado, por decisão da Diretoria, a estrutura organizacional da Empresa 1 não foi revista. A revisão estava ocorrendo quatro anos após a implementação, na época da coleta de dados para esta pesquisa. Alguns funcionários comentaram que as alterações na estrutura eram necessárias desde a implementação do R/3. Por outro lado, outros funcionários acreditavam que, decorridos esses quatro anos, todos já estavam mais capacitados para identificar quais mudanças eram realmente necessárias, pois já conheciam o R/3 e já estavam adaptados a desenvolver suas atividades com o uso desse sistema. Infelizmente, não é possível avaliar se o desempenho da empresa teria sido melhor se as alterações tivessem ocorrido na fase de implementação do R/3.

Embora não tenha sido executada a revisão da estrutura, algumas alterações foram necessárias para alinhar a empresa ao R/3. Foi criada a área denominada Controladoria, para desenvolver as atividades relacionadas à Contabilidade Gerencial. Pode-se dizer que essa área foi criada para atender à estrutura do R/3, pois as atividades que foram direcionadas a ela já eram desenvolvidas na empresa e foram agrupadas ali porque todas passaram a ser executadas através do módulo CO do R/3. A Diretoria deliberou que a Contabilidade Financeira e a Controladoria ficassem subordinadas à mesma Gerência.

Com relação aos cargos da área de Contabilidade, a divergência existente entre a nomenclatura dos cargos constante nos documentos da empresa e a nomenclatura informada pelos seus ocupantes reflete a necessidade de mudança, pois como algumas atividades mudaram, a estrutura de cargos deveria ter acompanhado tais alteração, e acompanhou, todavia, informalmente.

Quanto ao número de funcionários da área de Contabilidade, o fato de não ter havido redução pode ser melhor entendido a partir da análise das alterações nas atividades, que serão comentadas na seqüência, no item 4.1.6.3. Como não houve alteração no volume de trabalho na área, também não houve necessidade de redução de pessoal. A Alteração que se fez necessária foi a transferência de dois funcionários para o setor Pool de Recebimentos, pois havia a necessidade de pessoas com conhecimento contábil nesse setor; entretanto esses dois funcionários foram substituídos. É importante comentar que o R/3 tem o potencial de reduzir algumas atividades na área de Contabilidade Financeira e agilizar a execução das atividades que permaneceram e, portanto, seria compreensível que houvesse redução no número de 
funcionários. Todavia, dependendo de algumas decisões tomadas durante a implementação, esse potencial pode ou não se tornar realidade.

\subsubsection{Influência da implementação do ERP nas atividades}

\subsection{Contabilidade financeira}

Algumas atividades referentes ao registro contábil dos materiais adquiridos já eram descentralizadas antes da implementação do $\mathrm{R} / 3$, e o restante dessas atividades foi descentralizado com o R/3. Outras atividades, como por exemplo, apuração de impostos, fechamento contábil, levantamento de documentos, elaboração de cartas de correção (impostos), entre outras, continuaram sendo realizadas na Contabilidade, todavia, com o uso do sistema R/3, facilitou sobremaneira a execução das mesmas, agilizando todo o processo. Entretanto, não houve redução no volume de trabalho da Contabilidade porque foi intensificada a atividade de conferência dos registros contábeis executados em outras áreas. Além disso, foram mantidos na Contabilidade alguns registros contábeis de despesas diversas.

Percebe-se que não há confiança na qualidade dos dados inseridos no sistema e isso demanda demasiado esforço em conferência, uma vez que todas as informações disponibilizadas terão por base esses dados, ou seja, se os dados forem ruins, a informação será ruim. É provável que a insuficiência de treinamento (FCS), a inadequada avaliação da cultura organizacional (FCS) e o inadequado dimensionamento dos reflexos da resistência às mudanças estejam entre os fatores que explicam este cenário.

Contudo, segundo os funcionários da área de Contabilidade, o R/3 promoveu a conscientização dos demais funcionários da empresa sobre os reflexos que suas atividades provocam na Contabilidade. Por outro lado, erros freqüentes continuaram a ocorrer, os quais prejudicam as atividades na Contabilidade (a ponto de intensificar as conferências). Parece claro que, embora as pessoas reconheçam que sua atividade afeta outras atividades do processo, não há comprometimento destes em fazer certo da primeira vez. Outra questão a ser observada é que os erros ocorrem principalmente na área de vendas, a qual tem como foco de atuação, tradicionalmente, o aumento das vendas, ficando as demais atividades do processo em segundo plano. Talvez se tivesse ocorrido a revisão dos processos (FCS), se tivesse havido apoio ao projeto por parte da Diretoria de forma mais explícita (FCS), se os treinamentos 
tivessem sido mais intensos (FCS), se os funcionários tivessem sido preparados e mantidos informados sobre as mudanças (FCS) e se a cultura da empresa tivesse sido melhor compreendida (FCS), esse comprometimento teria sido alcançado.

Quanto ao controle do imobilizado, como o R/3 permitiu a visualização de todos os bens da empresa (os que estavam cadastrados), as atividades inerentes ao controle do imobilizado foram mais valorizadas. Pode-se dizer que o R/3 promoveu essa valorização.

A atividade de suporte de informações aos demais funcionários da empresa foi acrescentada na área de Contabilidade, pois os usuários do R/3 têm pouco conhecimento sobre Contabilidade e freqüentemente precisam de auxílio em suas atividades. As dúvidas estão mais relacionadas à legislação e ao direcionamento dos registros quanto às contas contábeis.

\subsection{Contabilidade gerencial}

As atividades relacionadas à Contabilidade Gerencial foram centralizadas na área de controladoria porque o módulo CO ficou sob responsabilidade dessa área e é através deste módulo que as atividades são realizadas.

Com o R/3, a elaboração dos custos foi modificada. O sistema permitiu que fossem adotados melhores critérios de rateio e as apropriações ficaram mais detalhadas, possibilitando a análise gerencial de custos sob diversos aspectos e com grande riqueza de detalhes. Para tanto, foi necessário um conhecimento mais aprofundado sobre os processos da empresa.

Da mesma forma, o R/3 facilitou a execução das atividades relacionadas à elaboração de orçamentos e de relatórios gerenciais, promovendo mais agilidade e maior riqueza de detalhes nas informações, o que contribui para a análise e entendimento do desempenho da empresa.

Foi adicionada à área de controladoria a atividade de suporte de informações aos demais funcionários da empresa sobre questões relacionadas principalmente a custos e orçamentos. A elaboração de custos era desenvolvida anteriormente na Contabilidade Financeira e os demais funcionários não tinham muito acesso aos critérios adotados e não participavam das decisões sobre esses critérios, portanto, não precisavam de suporte sobre isso. Quanto a orçamento, essa atividade já existia e também já era fornecido suporte aos funcionários para elaboração e 
acompanhamento deste instrumento. Todavia, segundo uma pessoa da Controladoria, tal suporte foi intensificado.

De forma geral, tanto na Contabilidade Financeira quanto na Contabilidade Gerencial as atividades de digitação foram reduzidas e substituídas pelas atividades relacionadas a análises. É também comum às duas áreas a necessidade de usar o programa Excel para a elaboração de relatórios, visto que o R/3 apresenta deficiências nesse sentido. Por outro lado, torna-se muito fácil obter os relatórios desejados, tendo em vista que o R/3 possui todos os dados e permite a extração destes e sua transferência para o Excel com muita facilidade.

\subsubsection{Influência da implementação do ERP nos conhecimentos e habilidades}

Com relação aos conhecimentos técnicos (contábil e áreas correlacionadas), houve discordâncias quanto à necessidade de que os funcionários da área de Contabilidade possuam graduação em Ciências Contábeis como grau mínimo de instrução. Alguns funcionários acreditam que apenas a experiência na área é suficiente para capacitá-los a desenvolver suas atividades. É possível que essa postura seja decorrente do fato de alguns funcionários da área possuírem graduação em Ciências Contábeis, outros possuírem titulação em Técnico em Contabilidade e outros, titulação em outras áreas não correlacionadas. Embora o foco da pesquisa tenha sido as exigências do cargo, algumas pessoas apresentaram dificuldades em separar as exigências do cargo das suas próprias competências.

Sobre os conhecimentos gerais, tendo em vista que a estrutura do $\mathrm{R} / 3$ tem a orientação por processos, é fundamental que os funcionários conheçam os processos da empresa e como sua atividade reflete nas demais atividades da empresa, a fim de que ele possa ter mais responsabilidade sobre a informação que disponibiliza e possa estar mais comprometido com a qualidade da informação gerada pelo sistema. O R/3 também demanda que seus usuários tenham algum conhecimento sobre o idioma inglês, necessário tanto para explorar o sistema quanto para esclarecer dúvidas junto ao suporte técnico da empresa SAP.

Quanto aos conhecimentos em tecnologia da informação, além de conhecer o R/3, é preciso conhecer o Excel, uma vez que o R/3 apresenta deficiência relacionada à emissão de relatórios e precisa do apoio do Excel para executar tais atividades. 
Quanto às habilidades, o R/3 reforçou a necessidade por habilidades de comunicação e de relacionamento interpessoal. Com o R/3, os funcionários da área de Contabilidade estão constantemente em contato com os funcionários dos demais setores para esclarecer dúvidas, orientar quanto aos procedimentos e auxiliar na solução de problemas.

Com relação às habilidades intelectuais, as alterações nas atividades demandam que os funcionários tenham mais senso crítico e capacidade de análise.

\subsubsection{Considerações finais}

Foi possível perceber que a área de Contabilidade da Empresa 1 fez algumas adaptações para resolver seus problemas, como aumentar a conferência dos lançamentos e continuar centralizando na Contabilidade todos os registros possíveis. Aparentemente, o sistema poderia ser melhor utilizado nesta área, mas a maioria dos funcionários não tem essa percepção e não questiona se 'poderia ser diferente’. Um dos funcionários da Contabilidade participa de um grupo que discute o R/3 e pôde conhecer outras funcionalidades que não são exploradas na Empresa 1. Segundo ele, o R/3 “[...] é uma ferramenta fabulosa, mas não estamos usando ela com inteligência. Será que o que estou fazendo aqui está correto? Não existe uma forma mais fácil?” Na opinião dessa pessoa, deveria haver um funcionário que orientasse os demais para o uso mais eficiente do R/3.

Outra questão que já não está relacionada diretamente ao ERP, mas que é importante destacar, é a separação que a Empresa 1 faz entre Contabilidade e Controladoria. Foi demonstrado, nas descrições de cargos destas duas áreas, que na Contabilidade são executadas as atividades referentes à Contabilidade Financeira e na Controladoria são executadas as atividades referentes à Contabilidade Gerencial.

Percebe-se que nenhum dos entrevistados faz menção ao termo Contabilidade Gerencial. Todos estão restritos à Contabilidade Financeira. As atividades desenvolvidas na área de Controladoria são vistas como totalmente independentes da Contabilidade, esta apenas fornece os dados. Anteriormente ao R/3, essas atividades, com exceção da elaboração dos custos, faziam parte da área de planejamento e só houve alteração devido à adequação à estrutura do R/3. Apenas um dos entrevistados mencionou que o módulo CO do R/3 deveria fazer parte da Contabilidade, mas justificou que era devido à estrutura do sistema e também 
não fez referência à Contabilidade Gerencial. Os funcionários da Controladoria vêem essa área como planejamento, e consideram que a atividade de custos não faz parte do foco dessa área.

Ao que parece, falta consciência do potencial da Contabilidade como fornecedora de informações à gestão da empresa.

\subsection{Caso 2 - Empresa 2}

\subsubsection{Contextualização}

A Empresa 2 é uma cooperativa agroindustrial da região oeste do Paraná que atua de forma integrada junto aos cooperados, desenvolvendo todas as etapas desde a produção à comercialização dos produtos agropecuários, provendo a devida armazenagem e industrialização da matéria prima e proporcionando aos produtores a colocação de seus produtos no mercado consumidor.

Tem como atividade principal a avicultura, mais especificamente a produção das matrizes, industrialização e comercialização das aves, o que representa 55\% de sua atividade econômica. A atividade agrícola se dedica às culturas de soja, milho, trigo, café, algodão, arroz e feijão. Também desenvolve as atividades suinícola e sericícola. Além disso, a cooperativa também possui mini mercados que estão presentes em todas as cidades ou localidades onde existem unidades de recebimento de cereais.

Foi fundada em 1963 e hoje conta com dez unidades na região oeste do Paraná, onde são desenvolvidas as atividades agroindustriais; e mais três unidades, exclusivamente para vendas, em outras regiões do país. Quando a coleta de dados para esta pesquisa foi realizada, a Empresa 2 apresentava faturamento anual em torno de R\$ 409 milhões (quatrocentos e nove milhões de reais).

A Empresa 2 tem uma experiência muito positiva em sistemas informatizados. Está claro para a Empresa 2 que os sistemas informatizados são muito importantes para o crescimento e evolução de seus processos. Na época da coleta de dados para esta pesquisa, a Empresa 2 
estava na fase inicial de um projeto de implementação da ferramenta BW (Business Information Warehouse) também da empresa SAP, com o objetivo de atender à necessidade da empresa por relatórios.

Outra preocupação é a constante revisão de sua estrutura organizacional, inclusive de seus cargos e de seus processos. Para tanto, conta com uma área de O\&M e também com uma área de cargos e salários. A área de O\&M é responsável pela análise da estrutura organizacional e dos processos, e as sugestões são discutidas com os gerentes e com a diretoria. A área de Recursos Humanos, especificamente o setor de cargos e salários, é responsável pelo suporte aos gerentes no que diz respeito à análise de cargos. Os gerentes solicitam as reavalições dos cargos ou propõem um cargo novo e a sugestão é apreciada por um comitê formado pelos diretores e gerentes.

No que se refere à área de Contabilidade da Empresa 2, é importante ressaltar que o atual contador, que ocupa o cargo de supervisor contábil, foi contratado após a implementação do $\mathrm{R} / 3$, substituindo a contadora anterior que pediu demissão. A saída da contadora, segundo informações, não está relacionada com a implementação do R/3. Quanto às informações sobre a área de Contabilidade anteriormente ao R/3, que deveriam ter sido obtidas junto ao contador, foram fornecidas pela encarregada, a qual está há muitos anos neste cargo, participou do projeto de implementação como usuário-chave e é a pessoa que responde pela Contabilidade na ausência do contador. Portanto, essa pessoa tem totais condições de descrever a realidade da área contábil antes da implementação do R/3.

\subsubsection{Informações gerais sobre a implementação do R/3}

A política de informatização da empresa até 1999 foi de desenvolver todos os seus sistemas internamente, até o momento em que a empresa atingiu determinado porte e o sistema em uso não atendia mais suas necessidades. A estrutura de desenvolvimento existente já não era suficiente para atender à crescente demanda por manutenção dos sistemas que estavam sendo utilizados, nem para atender à necessidade de informatizar novos processos de negócio.

Tendo em vista esse contexto, a Empresa 2 foi buscar no mercado soluções que atendessem suas necessidades de informações, e que também proporcionassem o acesso a ferramentas 
mais modernas para coleta e análise de informações para a tomada de decisão. O foco era ter um sistema que auxiliasse na gestão. Após a análise de diversas opções, o ERP demonstrou ser o mais adequado para suprir tais necessidades.

O processo de pesquisa de soluções no mercado iniciou em junho de 1999 e se estendeu até o mês de novembro. Nesse momento, a empresa estava decidindo entre três sistemas de fornecedores diferentes e as variáveis que a fizeram optar pelo R/3 da empresa SAP foram: base de dados, continuidade no mercado e incentivo pela evolução do sistema. A preparação para o projeto iniciou em dezembro de 1999 com previsão para entrada em produção em 15/09/2000. Após um atraso de duas semanas, a entrada em produção ocorreu em 01/10/2000, decorridos 10 meses de trabalho, por big bang.

Os módulos implementados foram: FI, CO, MM, PP, SD, QM e PM. O conceito da Empresa 2 era manter o R/3 standard. Todavia, por ser uma cooperativa, alguns de seus processos não puderam ser atendidos pelo $\mathrm{R} / 3$ e a opção foi desenvolver soluções separadas que foram interfaceadas com o R/3 para transferência de dados. A área de recursos humanos da empresa também está fora do R/3.

As especificidades da Empresa 2 foram o cerne de diversos problemas com consultores, os quais conheciam bem o R/3, mas não conseguiram atendê-la em algumas de suas particularidades. Um dos funcionários fez o seguinte comentário: "Nós não tínhamos consultores de negócio buscando uma solução, eles queriam pegar o nosso negócio e configurar dentro do R/3 e algumas coisas não tinha como configurar dentro do R/3 porque não contemplava.” Houve troca de consultor por quatro vezes, até que os problemas da cooperativa fossem resolvidos, pois estes acreditavam que tudo que era específico de alguma maneira poderia ser colocado dentro do R/3, e isso não aconteceu. Segundo um funcionário da empresa, "Eles também se frustaram nesse sentido: não, o R/3 atende, nós vamos arrumar uma solução, e chegou num ponto que eles falaram não dá mesmo, não tem jeito.” e completou: “[...] tinha coisas que estavam previstas para colocar dentro do projeto e que acabaram utilizando o sistema anterior nosso, interfaceado com o R/3.”

Quanto ao gerenciamento das mudanças que ocorrem numa implementação desse porte, a Empresa 2 preocupou-se com as mudanças organizacionais que poderiam ou deveriam ocorrer e também com os problemas que poderiam surgir, relacionados aos funcionários. Para 
minimizar os problemas, tomou algumas providências:

a) promoveu ampla divulgação de todo o projeto, através da entrega mensal de um informativo onde constava a fase em que o projeto se encontrava, as mudanças que seriam necessárias, como os funcionários poderiam se envolver no projeto, entre outros;

b) preocupou-se constantemente em manter a equipe do projeto motivada, promovendo palestras que contavam o com apoio de um psicólogo e eventos de confraternização (churrasco, futebol, torneio de truco, etc);

c) o diretor-presidente, juntamente com alguns membros da equipe do projeto, fazia visitas periódicas às unidades divulgando o projeto, esclarecendo dúvidas e solicitando o apoio dos funcionários;

d) a equipe do projeto indicou como usuário-chave as pessoas que realmente conheciam as atividades e a diretoria deu total apoio a essas indicações;

e) promoveu a revisão dos processos, reorganizando aqueles que foram necessários.

Na opinião de um dos funcionários, “A participação da diretoria foi fundamental para o sucesso do projeto, que deu confiança e motivação.” A diretoria convocou a todos para que apoiassem a implementação do software, para que todos trabalhassem para o sucesso do projeto e foi enfática: se alguém acreditava que não daria certo ou não estava satisfeito, poderia sair da empresa porque não seriam admitidos problemas dessa natureza.

O resultado do projeto foi satisfatório, embora no início da utilização deste sistema a empresa tenha enfrentado um período de dificuldade de adaptação. No que se refere à Contabilidade, a equipe de suporte (pessoas que participaram do projeto no módulo FI do R/3) era solicitada o tempo todo, porque os funcionários das outras áreas da empresa não conseguiam trabalhar. Mesmo as pessoas que integraram a equipe que desenvolveu o projeto tiveram, inicialmente, certa dificuldade em absorver um sistema tão complexo. Segundo um dos integrantes da equipe do projeto:

o R/3, quando falaram dele para a gente e mostraram para nós, nossa, todo mundo já estava desesperado porque era um bicho de sete cabeças. Fomos fazer o curso em São Paulo, 5 dias só vendo o R/3, a gente olhava para aquilo lá e pensava: nossa, isso aqui eu não vou saber nunca, não tem nem como mexer.

Entretanto, o sistema entrou em produção e após três anos de sua utilização, quando os dados desta pesquisa foram coletados, embora os funcionários ainda apresentassem algumas 
dificuldades em manusear o R/3, a atitude destes era: como utilizar melhor o R/3, uma vez que ele já se tornou essencial para a empresa.

\subsubsection{Estrutura organizacional}

A Empresa 2 tem sua estrutura organizacional formada por quatro níveis: diretoria (aqui também considerados o conselho de administração e a assembléia geral), gerência, chefias e operacional. Os níveis de diretoria e de gerência contam com algumas assessorias (staff).

Conforme comentado anteriormente, no item 4.2.1, existe uma preocupação da empresa em rever constantemente sua estrutura organizacional, buscando uma organização que otimize a eficiência. Quando foi decidido implementar o R/3, a consultoria contratada para executar essa implementação orientou que fosse feita a revisão dos processos. Juntamente com a revisão dos processos, a empresa fez também a revisão da estrutura organizacional. Segundo um dos funcionários: “A gente já estava precisando de algumas mudanças e aproveitamos o R/3 para fazer essa reestruturação.”

Algumas mudanças aconteceram, no nível de diretoria e gerentes. Na estrutura antiga havia duas assessorias ligadas à diretoria e na estrutura nova foram criadas mais quatro assessorias para esse nível. Quanto ao nível de gerentes, havia na estrutura antiga oito divisões (gerências). Na estrutura nova, esse número foi reduzido para cinco, foi criada uma nova área chamada suprimentos e a denominação passou a ser gerência, ao invés de divisão. Portanto, a Empresa 2 passou a ter seis gerências.

Uma dessas gerências é a Centro-Administrativo, que agrega todas as unidades ou entrepostos da cooperativa (postos de recebimento e armazenamento de grãos e outros produtos, que conta com uma área administrativa e também um mini mercado). Existia a unidade Cafelândia e todas as outras eram subordinadas a ela. Agora existe a gerência Centro- Administrativo e Cafelândia passou a ser uma unidade como outra qualquer dentro da Centro Administrativo. Segundo um dos funcionários: “A própria estrutura do R/3 fez com que a empresa criasse a unidade centro administrativo”, e também comentou: “[...] principalmente essa parte de suprimentos, compras, o R/3 tem alguns direcionamentos que a mudança na estrutura facilita o fluxo das informações.” 
Na estrutura organizacional da área de Contabilidade, também houve alterações. A área de Contabilidade estava ligada, na estrutura antiga, à divisão administrativa. Na nova estrutura, a divisão administrativa e a divisão financeira foram unificadas sob a denominação Gerência Administrativo/Financeira. A Contabilidade está agora subordinada a essa gerência. Na estrutura antiga, a denominação da área de Contabilidade era Departamento Contábil e era dividida nos setores escrita fiscal, contabilização e almoxarifado. Na nova estrutura, a denominação da área passou a ser apenas Contabilidade e foi dividida nos setores contabilização/custos, escrita fiscal/imobilizado. Posteriormente, em janeiro de 2002, passados um ano e três meses do início da utilização do R/3, foi criado um setor chamado Célula de Entrada que está subordinado à Contabilidade.

Essa revisão posterior da estrutura ocorreu porque, com a utilização do R/3, foram detectados problemas quanto à recepção de materiais e ao cadastro dos mesmos no sistema. O cadastro de materiais é muito importante no R/3, e os problemas que vinham ocorrendo estavam comprometendo o adequado funcionamento do sistema. Na realidade, a Célula de Entrada não surgiu da reestruturação da área contábil e sim da área de compras. Nas unidades, também existe o setor Célula de Entrada, subordinado ao gerente de cada unidade. Todavia, são subordinados funcionalmente à Contabilidade, tendo em vista que esta é responsável por todo o suporte para as atividades realizadas nas células. Maiores detalhes sobre as atividades desse setor são apresentados na seqüência, no item 4.2.4.

Quando o sistema foi implementado, houve reavaliações de cargos na empresa e mudanças foram realizadas. Quanto aos cargos da área de Contabilidade, também ocorreram algumas alterações. Anteriormente ao R/3, os cargos eram supervisor contábil, encarregado fiscal, encarregado contábil, auxiliar administrativo (níveis I e II), auxiliar de contabilização (níveis I e II), auxiliar de escrita fiscal (níveis I e II), auxiliar de controle patrimonial (níveis I e II), auxiliar de recepção (níveis I e II), telefonista, maloteiro, encarregado almoxarifado/administrativo. Com o R/3, já considerando a Célula de Entrada, as alterações nos cargos foram as seguintes:

- os cargos encarregado contábil e encarregado fiscal foram unificados sob a denominação encarregado contábil-fiscal;

- os cargos auxiliar de contabilização, auxiliar de escrita fiscal e auxiliar de controle 
patrimonial foram unificados sob a denominação assistente contábil-fiscal;

- foi criado o cargo analista de custos;

- os cargos telefonista, maloteiro e encarregado almoxarifado/administrativo foram extintos da Contabilidade com a transferência do setor de almoxarifado para a área de suprimentos, já que o almoxarifado não fazia parte do foco de negócios da Contabilidade.

Um dos funcionários da Célula de Entrada está registrado com o cargo assistente contábilfiscal, todavia, desempenha as mesmas atividades previstas para o cargo de auxiliar de recepção de materiais. Esse funcionário foi transferido do setor de patrimônio, na Contabilidade, para a Célula de Entrada. Os demais funcionários da Célula de Entrada foram transferidos das áreas de compras.

Antes da implementação do R/3, havia mais ênfase em digitação e conferência, como será comentado posteriormente no item 4.2.4. Nessa realidade, os cargos eram condizentes com o nível de auxiliares. Com o R/3, houve mudança para o nível de assistente contábil, procurando enxugar um pouco a estrutura de cargos e qualificar mais o pessoal. As atividades passaram a ser mais relativas à análise e à conciliação. Foram mantidos os cargos de auxiliares para serviços burocráticos. Essa alteração nos cargos e também as alterações nas atividades acabaram valorizando os cargos da área de Contabilidade.

Com relação à redução de pessoal na área de Contabilidade, havia essa expectativa, por ocasião da implementação do R/3. De acordo com um funcionário: "Nós tínhamos uma expectativa e até em algum momento víamos uma oportunidade de redução do quadro dentro da área de Contabilidade e não só na área de Contabilidade, mas nas demais áreas e isso não ocorreu. O que ocorreu foi uma mudança na maneira de trabalhar.”

Na verdade, houve três desligamentos da área: duas pessoas se desligaram da empresa por motivos particulares e uma terceira pessoa foi transferida para outra área. Segundo um funcionário da Contabilidade, essa terceira pessoa trabalhou o primeiro dia com o R/3 e no dia seguinte chegou em sua mesa, muito alterado, e falou "Eu não trabalho mais aqui e nem na Empresa”; a questão foi solucionada com sua transferência para o setor de cobrança. As pessoas ligadas ao setor de almoxarifado foram transferidas juntamente com a readequação estrutural do setor. Uma pessoa que era do setor de patrimônio foi para a Célula de Entrada, 
ou seja, continuou na área de Contabilidade, mas em outra atividade. A contadora pediu demissão da empresa por motivos particulares, mas foi substituída por uma pessoa contratada na ocasião.

$\mathrm{Na}$ época da implementação do sistema, verificou-se a necessidade de colocar uma pessoa com experiência em Contabilidade na área de compras, mas como não havia disponibilidade de pessoal, resolveram treinar os compradores para suprir essa necessidade.

Aproximadamente um ano após a implementação do $\mathrm{R} / 3$, foi criada uma área chamada Assessoria de Custos que está subordinada diretamente à Gerência Administrativo/Financeira. A expectativa é transformá-la, futuramente, na Controladoria da Empresa. Essa área foi criada com as seguintes atribuições e responsabilidades:

- definir modelo conceitual e critérios para formação de custos nas áreas industriais;

- dar suporte para a elaboração do orçamento anual da empresa;

- manter gerências e diretoria informadas sobre o cumprimento das metas orçamentárias;

- contribuir para uma gestão de custo e resultado eficaz da empresa através de indicadores de desempenho.

Inicialmente, a assessoria de custos foi instalada na área de O\&M, já que o funcionário que assumiu o cargo assessor de custos era da área de O\&M. Algum tempo depois, foi transferida para as instalações físicas da Contabilidade. A decisão de não deixar essa nova área subordinada à área de Contabilidade deve-se ao fato de que, até então, a Empresa trabalhava quase que exclusivamente com a Contabilidade Financeira e como essa nova área está voltada para a Contabilidade Gerencial, entendeu-se que era melhor não correr o risco de que os paradigmas presentes na Contabilidade Financeira pudessem interferir na evolução do que seria a Contabilidade Gerencial.

Com relação às mudanças na infra-estrutura, houve uma reforma no prédio onde a Contabilidade estava instalada, que acarretou na redistribuição do espaço físico. A área de Contabilidade era no primeiro andar do prédio e dividia a sala com a gerência. Após a redistribuição do espaço físico a Contabilidade foi transferida para o térreo, em uma sala 
menor. Quando a Assessoria de Custos foi levada para as instalações da Contabilidade o espaço diminuiu e foi preciso reorganizar todo o lay-out, inclusive com a aquisição de novos móveis, com mesas em formato de células. Nesse novo arranjo, os setores da Contabilidade foram aproximados e um funcionário chegou a comentar: “[...] porque antes era o pessoal de patrimônio de um lado, parte contábil de outro e parte fiscal de outro e com o R/3 a gente viu que poderia trabalhar mais junto, por exemplo patrimônio e contábil se conversam.” Entretanto, se não fossem as restrições quanto a espaço físico, os setores não teriam sido aproximados.

\subsubsection{Atividades}

\subsubsection{Contabilidade financeira}

Quando questionados sobre a ocorrência ou não de mudanças na área de Contabilidade da Empresa 2, os funcionários foram unânimes em afirmar: houve mudanças. Segundo os funcionários da área de Contabilidade, o conceito do R/3 é diferente. No sistema antigo, havia conciliação entre contas a pagar, a receber, bancos, caixa etc. e as contas respectivas na Contabilidade, pois não havia confiança. Isso era necessário devido a uma prática enraizada na empresa, na qual as pessoas dos diversos setores realizavam suas atividades sem a preocupação de como seu trabalho afetaria posteriormente a Contabilidade e, quando ocorriam erros, e estes eram freqüentes, a Contabilidade tinha a obrigação de corrigi-los, se quisesse ter informações confiáveis, gerando as infindáveis conciliações. De acordo com um dos funcionários, “[...] fazia-se muitas coisas erradas que demoravam para ser acertadas e os usuários não tinham interesse em fazer certo da primeira vez porque tinha alguém arrumando o erro.” O sistema de informação anterior ao R/3 permitia tais ajustes.

No início da utilização do R/3, a Contabilidade Financeira ainda tentou arrumar os erros dos demais, como faziam na época do outro sistema. "É muito difícil fazer isso num sistema integrado como o R/3”, disse um dos funcionários, “[...] isso não foi permitido.” A determinação da equipe do projeto, apoiada pela Diretoria, foi: a Contabilidade deve dar suporte para que os demais usuários solucionem os seus problemas; quem deve corrigir os erros é o usuário. Esse foi um grande desafio, mas foi também, segundo os funcionários da área de Contabilidade a maior mudança: “[...] as pessoas hoje têm que, além de saber o 
trabalho delas, conseguir ver o que isso vai refletir dentro da organização. [...] o usuário, esse foi um ganho que a gente teve, ele passou a ter uma visão maior do processo e se ele não conseguisse ver isso ele não conseguiria trabalhar também.” A postura adotada pela Empresa 2 é a seguinte: que a Contabilidade saia do seu ambiente interno e vá até os demais setores da empresa dar suporte aos usuários, para que eles “[...] façam o certo da primeira vez, para que depois não precise ficar corrigindo erros.”

Tendo em vista essa postura, uma atividade que a área de Contabilidade estava priorizando na época da coleta de dados é o treinamento aos demais usuários do $\mathrm{R} / 3$, sobre os diversos assuntos relacionados à Contabilidade. Sob a coordenação da encarregada, um planejamento de treinamento havia sido desenvolvido e os treinamentos já tinham sido iniciados. A intenção é manter permanentemente um programa de reciclagem. Segundo uma funcionária:

\begin{abstract}
A gente está trabalhando bastante, mas isso é uma coisa que vai demorar um pouco, porque mudar da noite para o dia você não consegue, [...] porque antes do R/3 você tinha essa visão que a Contabilidade caía tudo aqui, ela compilava e arrumava os dados. Agora não, tem que chegar tudo pronto e você montar seu relatório e trabalhar os dados e não acertar, deu errado você vai lá e acerta. Se deu errado você vai lá na origem, conversa, trabalha, e vê porque está acontecendo isso.
\end{abstract}

Na época da coleta de dados para a pesquisa os benefícios oriundos do treinamento dos funcionários já estavam sendo percebidos. Além de mudar a postura dos demais usuários do R/3, também foi preciso trabalhar para mudar a postura das pessoas na área de Contabilidade.

Como conseqüência, o conhecimento sobre os processos da empresa aumentou. Segundo uma funcionária: “[...] o conhecimento profissional aumentou, o R/3 levou as pessoas a conhecer a empresa toda, principalmente os processos, mesmo para tirar relatórios.” Isso proporcionou melhoria nas análises, proporcionou melhoria do uso da ferramenta de custo padrão (o padrão é muito próximo do real). As pessoas também ficaram mais comprometidas, “[...] chegou documento, tem que mandar para frente”, comenta uma das funcionárias e completa: “Hoje há consciência que se eu erro vai disseminar esse erro para os outros módulos.”

De forma geral, as atividades relacionadas a registros contábeis e conciliações foram substituídas por atividades que envolvem análise e, por conseqüência, a atividade de conferência dos registros contábeis com os documentos foi reduzida. Os registros contábeis são agora realizados pelos funcionários dos demais setores da empresa e não mais na área de Contabilidade (Contabilidade "nas pontas”), apenas alguns poucos foram mantidos. Para dar 
condições a estes funcionários “das pontas” para realizarem os registros contábeis, a área de Contabilidade está desenvolvendo um intensivo trabalho de suporte e treinamento.

O contador e o encarregado contábil-fiscal deixaram de desenvolver atividades operacionais e estão mais envolvidos com atividades de coordenação, de orientação sobre procedimentos e de suporte de informações, conforme pode ser verificado com mais detalhes nas explicações dos quadros 1.1 e 1.2 do apêndice 6 .

Como o sistema agilizou a execução das atividades, o fechamento contábil, que antes era realizado em quinze dias, foi reduzido para três a cinco dias.

As atividades de recepção de mercadorias, conferência da nota fiscal com o pedido e a inserção dos dados referentes às notas fiscais no sistema foram centralizadas para um setor denominado Célula de Entrada. Freqüentemente, havia problemas relacionados a tais atividades. Os funcionários não olham as mercadorias, apenas conferem o pedido e, se identificarem divergências, fazem contato com o comprador para que ele resolva o problema. Segundo um funcionário deste setor, [...] resolve o problema antes da mercadoria entrar, para o problema não entrar na organização.” Com exceção de um funcionário que foi transferido da Contabilidade, os demais funcionários da Célula de Entrada já exerciam essas atividades, mas eram alocados na área de compras dos diversos setores. Foi fundamental fazer parte dessa equipe uma pessoa com conhecimento em Contabilidade.

As atividades que envolvem controle do imobilizado passaram a ser mais valorizadas com o $\mathrm{R} / 3$, pois, segundo uma funcionária, o sistema deixou evidente os problemas relacionados ao imobilizado e também porque o custo relacionado aos bens passou a ser melhor controlado por cada área. Os detalhes sobre essa alteração podem ser consultados nas explicações do quadro 1.6, no apêndice 6.

Por fim, o R/3, no que diz respeito ao ICMS, gerou certo descontentamento porque ocorreram problemas na parametrização e para realizar as atividades relacionadas à apuração e controle do ICMS é necessário trabalhar com relatórios do Excel. 


\subsubsection{Contabilidade gerencial}

Antes da implementação do R/3, não havia na Empresa, formalmente, um setor responsável pela Contabilidade Gerencial. Algumas atividades relacionadas a relatório gerencial de custos e orçamentos eram de responsabilidade da contadora juntamente com o diretor administrativo.

Um funcionário afirma que, anteriormente ao R/3, "Era muito forte a Contabilidade Financeira, o pessoal era bom e dominava as atividades realizadas lá”; já a Contabilidade Gerencial não estava bem estruturada, o que em grande parte ocorria devido a falta de um sistema de informações que permitisse a elaboração de relatórios gerenciais. A Empresa 2 mantinha um sistema chamado Sistema de Gestão, desenvolvido em Excel com o auxílio de uma consultoria. Este sistema gerava diversas informações importantes como controle de produtividade por dia, orçamentos, custos, resultado total empresa, mas era muito trabalhoso. Segundo um dos funcionários, "Era muito trabalhoso mesmo, e os gerentes eram totalmente avessos àquele sistema porque exigia muito tempo das pessoas. Também não tinha garantia de consistência e confiabilidade, porque se a pessoa que alimentava as tabelas não alimentasse corretamente já havia problemas.”

A responsabilidade desse sistema era da área de O\&M. A área de Contabilidade inseria alguns dados sobre custos, sendo um dos funcionários responsável em alimentar todas as planilhas de custos gerenciais. Essa atividade foi descrita em detalhes nas explicações do quadro 1.7, no apêndice 6. Com o R/3, todas as atividades relacionadas a custos gerenciais passaram a ser desenvolvidas pelo assessor de custos, utilizando o CO/PA.

A atividade de elaboração de custos propriamente dita também mudou muito. Com o R/3, passou a ser utilizado o módulo CO e o trabalho passou a ser mais de análise. Anteriormente ao R/3, a atividade de elaboração de custos era desenvolvida pela contadora juntamente com o gerente administrativo, embora o custo de uma das unidades industriais (abatedouro) fosse elaborado pelo gerente desta unidade. Não se sabia sob quais critérios o custo era elaborado. Com o R/3, tais critérios são constantemente discutidos e os gerentes dos setores se envolvem nessa definição, pois agora eles também acompanham o orçamento e só admitem que sua área assuma os custos que realmente são de sua responsabilidade. Quando a coleta de dados para essa pesquisa foi realizada, essa atividade de elaboração de custos era desenvolvida por um funcionário da área de Contabilidade, que ocupava o cargo analista de custos, mas existia uma tendência para que ela fosse transferida para a área de assessoria de custos. 
Sobre a atividade de orçamento, esta também já existia antes da implementação do R/3. Todavia, era desenvolvida em planilhas do Excel, de forma muito trabalhosa, e não havia comprometimento das pessoas para que essa ferramenta funcionasse. Segundo um dos funcionários, "Antes era feito porque a diretoria pedia e a forma de fazer era outra, a diretoria determinava qual seria a redução que deveriam atingir e essa era a base de orçamento” e acrescentou, com o R/3, “[...] tivemos um ganho bom de comprometimento do pessoal com orçamento.” Para conseguir mais envolvimento das pessoas com o orçamento, além da alteração nos critérios para sua elaboração, a empresa adotou a postura de não permitir alterações nos valores orçados após o fechamento e aprovação do orçamento. Se existissem variações altas, o responsável deveria explicar para a diretoria os motivos, o que, na opinião de um funcionário, “[...] fez com que o pessoal se empenhasse mais em elaborar o orçamento de forma mais criteriosa.” Hoje, as reuniões da diretoria têm como base de apoio os valores orçados e realizados; em tais reuniões as variações são justificadas e os próximos períodos são projetados.

Também foi implementado um programa de remuneração variável, cujo gerenciamento ficou sob responsabilidade do assessor de custos. Esse programa é baseado em metas, as quais foram definidas por cada gerente. De acordo com um dos funcionários, “A política de metas e participação de resultados está muito forte na empresa. $\mathrm{O}$ R/3 ajudou nisso porque possibilitou acesso à informação para controlar tudo.” A empresa implementou uma política de ampla divulgação dos seus resultados também com intuito de obter o comprometimento dos funcionários. Nesse sentido, cada gerente reúne semestralmente seus colaboradores e divulga os resultados da área e da empresa, comenta sobre as metas e pede apoio e dedicação dos colaboradores.

A assessoria de custos participa dessa política preparando as informações, repassando-as para o gerente de cada unidade e explicando todas as informações para ele. Quem conversa com os funcionários é o gerente, mas todo o suporte é dado pela assessoria. É uma atividade nova na empresa. Na opinião do assessor de custos:

Uma coisa é a assessoria de custos, eu que estou aqui sentado na minha mesa, falar aos funcionários. O cara já olha e falar ah, esse cara está lá sentado na mesa, ele não entende nada do meu negócio, ele não sabe os problemas que nós temos lá e está pedindo para se comprometer com metas! Outra coisa é o gerente da área dele que está conversando com ele direto, que conhece aquela área, que é o responsável por aquela área estar pedindo o comprometimento dele. 
A todas essas atividades citadas anteriormente, está relacionada a atividade de suporte de informações aos demais funcionários da empresa.

Outra atividade desenvolvida pela assessoria de custos, embora esteja em dissonância com o foco dessa área, é o controle do módulo PP. Conforme descrito em detalhes no apêndice 6, nas explicações do quadro 2.1, houve problemas na parametrização desse módulo e, por refletir nas atividades de custos, a assessoria acabou assumindo o controle do módulo. Não foi demonstrada intenção em rever essa situação e transferir tais atividades para o setor de produção.

Essas diversas atividades estão sob responsabilidade do assessor de custos que, de fato, está desenvolvendo a Contabilidade Gerencial com a utilização do módulo CO. Como comentado anteriormente, a intenção no futuro é transformar a assessoria de custos na área de Controladoria. Na época da coleta de dados para esta pesquisa, a idéia era ter, dentro da assessoria de custos, uma pessoa voltada para CO, uma voltada para PP e o ocupante do cargo assessor de custos ficar mais na coordenação do que já existe e buscando novas soluções, novas possibilidades e estruturando a área. Segundo essa pessoa, “O que a gente precisa é estar nas unidades, estar vendo como o pessoal faz, tentando ajudar”. As outras duas pessoas da assessoria dariam o suporte operacional.

De forma geral, tanto para a Contabilidade Financeira quanto para a Contabilidade Gerencial, o R/3 auxiliou suas atividades fornecendo as ferramentas adequadas para o trabalho. Foi verificado que no início da utilização desse sistema houve certa dificuldade relacionada à falta de percepção dos funcionários de que o sistema por si não é autônomo e sim traz as ferramentas para os colaboradores trabalharem. Alguns funcionários acreditavam que já que todas as informações estavam “dentro do sistema” não precisava fazer mais nada porque já era tudo automático. Anteriormente ao R/3, muitos controles eram manuais e os funcionários viam as informações; com o R/3, alguns se perderam e não conseguiam mais realizar os controles. Situações como botas de segurança sendo fornecidas ao mesmo funcionário num curto espaço de tempo sem que ninguém percebesse levou a empresa, especificamente a assessoria de custos, a trabalhar no sentido de conscientizar de que não é mais preciso elaborar a informação, mas é preciso analisar. 
Por fim, embora o R/3 tenha facilitado o acesso às informações porque contém uma infinidade de dados armazenados, os relatórios padrões do R/3 não atendem às necessidades de muitos usuários. Tanto as atividades da Contabilidade Financeira quanto as atividades da Contabilidade Gerencial, para serem desenvolvidas a contento, precisam contar com o apoio do Excel para os relatórios. Os dados são extraídos do R/3 e transferidos para o Excel. Além do formato dos relatórios, outra dificuldade é quanto à lentidão do R/3 quando se solicita um relatório: "Dentro do R/3 é complicado, determinados relatórios demoram muito para você acessar” e ainda “[...] no R/3 como tem muita gente trabalhando fica meio lento.”

Essa situação levou a um descontentamento inicial e os funcionários da empresa como um todo, mais especificamente os funcionários da área de Contabilidade, queriam ter no R/3 os mesmos relatórios disponibilizados no sistema anterior, alegando que os relatórios do R/3 eram muito complexos e de difícil acesso, o que não foi permitido. Na época da coleta de dados, os problemas com relatórios ainda existiam e a diretoria da empresa tinha autorizado um projeto, que já havia sido iniciado, para a implementação da ferramenta BW (Business Information Warehouse), também fornecida pela empresa SAP, para atender à necessidade por relatórios. Segundo esclarecimentos da empresa, essa ferramenta é um data warehouse (banco de informações) de última geração que garante a disponibilidade fácil e instantânea de informações importantes para o planejamento e a tomada de decisões da organização.

\subsubsection{Conhecimentos e habilidades}

Foram identificadas algumas alterações relacionadas aos conhecimentos e habilidades necessários para realizar as atividades da área de Contabilidade, as quais são apresentadas nos parágrafos seguintes.

Quanto à necessidade de possuir graduação em Ciências Contábeis como grau de instrução, os entrevistados afirmaram ser importante e a empresa, nas descrições que definiu para cada cargo, menciona essa necessidade. Segundo informações dos funcionários da área de Contabilidade, é política da empresa contratar apenas pessoas graduadas em Ciências Contábeis para ocupar os cargos desta área. Essa exigência foi reforçada com a implementação do R/3. 
Também passou a ser fundamental o conhecimento dos processos da empresa pelas pessoas da área de Contabilidade e também o conhecimento da influência das atividades dos demais setores nas suas atividades, e vice-versa. Isso porque é preciso entender como cada informação foi gerada, qual é o caminho que os dados percorrem e qual a responsabilidade de cada pessoa nos processos, para poderem orientar os usuários do R/3 nas suas dúvidas. Segundo um dos funcionários: “Agora ficou mais fácil observar que as áreas são interligadas e você começa a conhecer outras áreas e a relação que elas têm com seu trabalho.”

Outra alteração identificada foi a maior necessidade de conhecimento em informática, principalmente de Excel, pois a maioria dos relatórios são emitidos com apoio deste programa, com dados extraídos do R/3. No sistema anterior, não havia a possibilidade de extrair dados e também não havia necessidade de trabalhar com os dados em outros sistemas.

Quanto às habilidades, foi identificado que a facilidade na comunicação e o bom relacionamento interpessoal são muito importantes aos funcionários da área de Contabilidade, visto que com o R/3 existe maior interação entre os funcionários.

As habilidades de coordenação de pessoas e liderança também ganharam mais importância para o cargo de encarregado contábil-fiscal, porque com a reestruturação dos cargos houve um aumento na quantidade de pessoas subordinadas ao encarregado.

De forma geral, a todos os funcionários da área de Contabilidade foi necessário desenvolver mais intensamente as habilidades de análise e de senso crítico. Isso ocorreu porque as atividades também mudaram de um perfil mais operacional para um perfil mais analítico, conforme comentado anteriormente no item 4.2.4.

É importante ressaltar que tais conhecimentos e habilidades já eram necessários, mas com a implementação do R/3 adquiriram maior importância.

Além de todos os conhecimentos e habilidades citados acima, é fundamental conhecer profundamente o R/3 para que as atividades possam ser adequadamente realizadas. Todavia, como esse sistema é muito complexo, para conhecê-lo é preciso que, além de participar de treinamento, o usuário explore o sistema e aos poucos vá descobrindo mais recursos e mais possibilidades de uso. 


\subsubsection{Análise}

Da mesma forma que no caso 1, item 4.1.6, será desenvolvida a análise sobre como a Empresa 2 procedeu no tocante aos fatores críticos de sucesso. A relevância desse entendimento está no fato de que muitas alterações na área de Contabilidade podem estar relacionadas a esses fatores críticos.

Posteriormente à verificação dos fatores críticos de sucesso, será apresentada a análise referente às mudanças na área de Contabilidade.

\subsubsection{Fatores críticos de sucesso (FCS)}

Na implementação de uma tecnologia de informação, é necessário que a equipe responsável pelo projeto tenha consciência de que estão sujeitos a diversos riscos e problemas que podem comprometer o sucesso da implementação e que, para minimizá-los, é fundamental observar os fatores críticos de sucesso que norteiam o projeto.

No caso da implementação de um ERP, Bancroft et al (1997) identificaram nove fatores críticos de sucesso e, relacionando-os à implementação do R/3 na Empresa 2, verificou-se que a maioria deles foi atendida. Alguns foram parcialmente atendidos visto que algumas falhas ocorreram, mas com o passar do tempo e a utilização do R/3 estas foram detectadas e oportunamente estão sendo corrigidas. Na seqüência, será apresentado como a Empresa 2 procedeu quanto aos nove fatores críticos de sucesso mencionados.

\subsection{Compreender a cultura da empresa}

Verificou-se que os dirigentes e a equipe de projeto da Empresa 2 tinham consciência de que haveria dificuldades em relação à adaptação dos funcionários ao R/3, visto que existia na empresa, segundo informações dos funcionários, um público muito variado, pessoas com diversos graus de escolaridade e conhecimento. Tinham consciência de que: “O R/3 só vai ter informações boas se o usuário entrar com informações corretamente.” Nesse sentido, a empresa procurou manter constantemente os funcionários informados sobre o que estava 
acontecendo, o que era o R/3, o que se esperava deles etc. Também procurou realizar treinamento para capacitar os funcionários a utilizarem o R/3, todavia, nesse item, houve falhas, como será melhor detalhado posteriormente. Além disso, a empresa se preocupou em deixar evidente para os funcionários que a Diretoria estava envolvida no projeto e contava com a colaboração de todos, o que garantiu maior confiança das pessoas com relação à validade do projeto.

\subsection{Iniciar a mudança dos processos de negócios antes da implementação}

A Empresa 2 promoveu a revisão dos processos, reorganizando aqueles que foram necessários. Havia a preocupação em alinhar o negócio da empresa com o R/3, para garantir um melhor aproveitamento do sistema. Conforme exposto na apresentação dos resultados, alguns processos não puderam ser atendidos pelo $\mathrm{R} / 3$, tendo em vista as particularidades da empresa. Destaca-se que é uma política da empresa sempre estar revendo seus processos de forma a torná-los mais eficientes e, para tanto, é mantida uma área de O\&M que é a responsável por coordenar tais revisões. Dessa forma, não houve resistências quanto ao atendimento desse fator crítico.

\subsection{Manter uma comunicação constante}

A Empresa 2 preocupou-se com este fator e para atendê-lo desenvolveu um canal de comunicação com os funcionários através de um informativo mensal que apresentava detalhes sobre o projeto, esclarecia sobre as mudanças que estavam acontecendo, e preparava os funcionários para o que ainda estava por vir. De forma geral, todos os funcionários tinham acesso às informações do projeto e sabiam exatamente o que esperar dele. Além disso, disponibilizou um serviço de atendimento através de telefone e e-mail para esclarecer as dúvidas quanto ao projeto.

\subsection{Garantir forte apoio dos executivos para o projeto}

Conforme comentado no item 4.2.2, alínea c), o diretor-presidente, juntamente com alguns membros da equipe do projeto, fazia visitas periódicas às unidades divulgando o projeto, esclarecendo dúvidas e solicitando o apoio dos funcionários. 


\subsection{Possuir um gerente de projeto qualificado}

O gerente de projeto designado pela Empresa 2 é uma pessoa extremamente capacitada, que conhece muito a empresa, o negócio, os processos e que é muito bem quista e respeitada pelos funcionários. Essa pessoa, na época do projeto, ocupava o cargo de gerente administrativo e mantinha relacionamento com todas as áreas da empresa, o que facilitava sua atuação junto aos gerentes e funcionários das áreas. Além disso, também era cooperado e, portanto, também tinha o apoio dessa classe.

\subsection{Escolher uma equipe de projeto balanceada}

Quanto aos experts em cada área de negócios, participaram da equipe de projeto as pessoas que realmente conheciam as atividades e a Diretoria deu total apoio a essas indicações. Para a seleção dessas pessoas era questionado a cada gerente: qual pessoa você não pode liberar para o projeto porque vai fazer falta na área? - foi exatamente essa pessoa que a equipe buscou.

Quanto aos especialistas em informática foi contratada uma consultoria da própria SAP para ser o suporte técnico do projeto. Além disso, a Empresa 2 possuía uma área de informática e os funcionários desta área também integraram a equipe de projeto como suporte técnico. Assim, todos os participantes da equipe tiveram dedicação exclusiva ao projeto.

\subsection{Escolher uma boa metodologia de projeto}

A Empresa 2 adotou a metodologia ASAP, desenvolvida pela empresa SAP, fornecedora do sistema R/3, com o intuito de padronizar os projetos de implementação dos seus softwares. Considerando que a empresa SAP é a líder no mercado nacional e mundial de ERP, conforme exposto no capítulo 2, item 2.1.1, e considerando também que todas as implementações do R/3 utilizam essa metodologia, é possível entender que a metodologia utilizada era adequada para o projeto.

\subsection{Treinar os usuários}

A Empresa 2 promoveu treinamento aos funcionários procurando capacitá-los para utilizarem o R/3. Todavia, houve falhas no dimensionamento das necessidades de treinamento e quando o sistema entrou em produção os funcionários ainda não estavam preparados para utilizá-lo. 
Na verdade, problemas dessa ordem acontecerem no início da utilização do R/3 podem ser considerados comuns, devido à complexidade do sistema. Todavia, decorridos dois anos de utilização, ainda havia problemas dessa natureza.

\subsection{Comprometer-se com a mudança}

A Empresa 2 preocupou-se constantemente em manter a equipe do projeto motivada, promovendo palestras que contavam com apoio de um psicólogo e eventos de confraternização (churrasco, futebol, torneio de truco etc). Também procurou manter um clima de descontração e companheirismo na equipe. Havia uma pessoa na equipe do projeto que tinha, entre outras atividades, a responsabilidade de promover eventos visando manter a equipe motivada.

\subsubsection{Influência da implementação do ERP na estrutura organizacional}

Ocorreram mudanças na estrutura organizacional da empresa como um todo. Na área de Contabilidade, as alterações referem-se: à forma de agrupar as atividades; à supressão de um setor (almoxarifado) com sua transferência para outra gerência; à criação do setor Célula de Entrada; à alteração na nomenclatura, conteúdo e especificações dos cargos; e à redução no número de funcionários. Além disso, foi criada a área Assessoria de Custos que está fisicamente instalada nas dependências da área de Contabilidade e cujas atividades estão relacionadas com a Contabilidade Gerencial.

O ERP exigiu alterações em alguns processos (FCS) para alinhar o negócio da empresa ao $\mathrm{R} / 3$, o que provocou mudanças em algumas atividades, como por exemplo, o registro contábil de uma venda de produto que com o R/3 é executado no momento em que a venda é realizada, pelo próprio vendedor. Como conseqüência, houve alteração na forma de agrupar as atividades nos setores da Contabilidade. Da mesma maneira, a criação do setor Célula de Entrada foi fruto de uma adequação da empresa às novas exigências do R/3.

Quanto à criação da área Assessoria de Custos, o R/3 trouxe ferramentas que possibilitaram desenvolver as atividades relacionadas à Contabilidade Gerencial, mas algum tempo depois da entrada em produção do sistema elas ainda não estavam sendo executadas. Com o intuito de utilizar esses recursos e obter informações gerenciais, a empresa decidiu estabelecer essa 
área para assumir tais atividades. A opção pela instalação da assessoria nas dependências da Contabilidade pode ser relacionada à preocupação da empresa com a cultura organizacional (FCS), no que tange à resistência a mudanças, pois estando os funcionários da área de Contabilidade (Contabilidade Financeira) continuamente em contato com o funcionário da Assessoria de Custos (Contabilidade Gerencial) a tendência é acontecer um compartilhamento de informações e, por conseqüência, pode haver a assimilação, por parte dos funcionários da Contabilidade, da cultura de preocupação com informações gerenciais para a gestão.

O fato da criação da área Assessoria de Custos e do setor Célula de Entrada ter ocorrido cerca de um ano após o início da utilização do R/3 está relacionado à necessidade de constante revisão do sistema e implementação de ajustes. A metodologia utilizada prevê esse procedimento. É uma prática bastante coerente, pois, após algum tempo de utilização do sistema, os usuários têm condições de verificar o que está bom e o que precisa melhorar.

A transferência do setor de almoxarifado para outra gerência foi uma mudança que a empresa gostaria de ter promovido há algum tempo, visto que este setor não era condizente com o foco de negócios da Contabilidade. A empresa aproveitou a implementação do R/3 e realizou essa alteração. Esse fato corrobora a afirmação de Turner (1998) de que a implementação de sistemas tem sido usada como oportunidade para executar mudanças organizacionais.

Tendo em vista as alterações nas atividades (menos atividades operacionais, mais atividades de análise, suporte técnico e treinamento de outros funcionários) os cargos que, conforme Zimpeck (1992) e Pontes (2000), comportam o agrupamento das atividades, também precisaram ser revistos. Houve reagrupamento de atividades em cargos mais amplos e, em decorrência da alteração da natureza das atividades, houve a valorização dos cargos.

Essas alterações na natureza das atividades também provocaram a redução de funcionários da Contabilidade. Um funcionário foi transferido para a Célula de Entrada porque houve a necessidade de uma pessoa com conhecimento contábil nesse setor; outro funcionário foi transferido para o setor de cobrança porque não se adaptou ao sistema em suas atividades; nos demais casos houve solicitação de demissão por parte dos funcionários, por motivos particulares. Outro fator que levou à redução do contingente foi a transferência do setor de almoxarifado. 


\subsubsection{Influência da implementação do ERP nas atividades}

\subsection{Contabilidade financeira}

A principal atividade que deixou de ser realizada na área de Contabilidade da Empresa 2 foi o registro contábil da maioria das transações da empresa, entretanto, alguns registros ainda foram mantidos na Contabilidade, a maior parte referentes a provisões. A estrutura do R/3 (mas também comum a todos os ERP) prevê que tais registros sejam executados pela pessoa que realiza a transação, no momento em que esta acontece, conforme já exemplificado anteriormente, no segundo parágrafo do item 4.2.6.2. Essas atividades foram substituídas por outras relacionadas a análises. Com o R/3, os funcionários da Contabilidade ficaram mais envolvidos em acompanhar os registros que outros executam; em oferecer suporte aos demais funcionários da empresa no intuito de esclarecer as dúvidas quanto aos procedimentos do R/3 e quanto à legislação; e oferecer treinamento, para que cada vez mais os conceitos e procedimentos referentes à Contabilidade no $\mathrm{R} / 3$ possam ser assimilados pelos demais funcionários. O treinamento e suporte foram adicionados como conseqüência da descentralização dos registros.

Na verdade, as novidades trazidas pelo R/3 para a Contabilidade Financeira da Empresa 2 estão mais relacionadas com a forma como as atividades são desenvolvidas, embora algumas atividades tenham sido adicionadas e outras suprimidas. Os depoimentos dos funcionários evidenciam que, com exceção dos registros contábeis, que de fato deixaram de ser executados na sua maioria, e das atividades de suporte e treinamento aos usuários do sistema que foram adicionadas, o R/3 provocou alterações no “como fazer" as atividades, auxiliando e facilitando sua execução e hoje, de acordo com um dos funcionários, “Não dá para imaginar a Empresa 2 sem o R/3.”

Essas mudanças envolveram a cultura da empresa (FCS), resistência a mudanças (riscos) e treinamento dos usuários (FCS). Embora a Empresa 2 tenha se preocupado com a resistência às mudanças e com a dificuldade dos funcionários em absorvê-las, houve um mau dimensionamento das necessidades de treinamento. Além disso, há que se considerar que mudar paradigmas, de ambos os lados (funcionários da Contabilidade e demais funcionários da empresa), é um processo demorado. Como conseqüência, muitos erros que refletiam na 
Contabilidade continuavam ocorrendo, gerando um clima de desconforto que abalava o relacionamento entre os funcionários da Contabilidade e os demais funcionários da empresa. Com a revisão do sistema, os problemas foram identificados e estão sendo resolvidos através de um programa de capacitação, que prevê treinamento contínuo sobre as práticas contábeis.

As atividades referentes à apuração de impostos, fechamento contábil, controle do imobilizado, entre outras, continuam sendo realizadas na Contabilidade, todavia, com o uso do sistema R/3, facilitou sobremaneira a execução das mesmas, agilizando todo o processo. Com relação ao controle do imobilizado, especificamente, como o R/3 permitiu a visualização de todos os bens da empresa (os que estavam cadastrados) nos respectivos setores, e como outras atividades relacionadas à Contabilidade Gerencial (que serão comentadas na seqüência) promoveram uma maior utilização das informações relacionadas ao imobilizado, as atividades inerentes ao controle do imobilizado passaram a ser mais valorizadas. Pode-se dizer que o R/3 promoveu essa valorização.

Quanto às atividades realizadas na Célula de Entrada - conferência da nota fiscal com o pedido e inserção dos dados referentes às aquisições no sistema (cadastro de materiais) - se os funcionários responsáveis por tais atividades possuíssem adequado conhecimento sobre as práticas contábeis e sobre o $\mathrm{R} / 3$ provavelmente não haveria necessidade da criação desse setor. Por sua vez, se a centralização dessas atividades fosse de fato estratégica, este setor poderia estar subordinado à área de compras (suprimentos), já que tais atividades estão mais próximas do foco de negócios da área de compras do que da área de Contabilidade.

Supondo que a centralização das atividades desenvolvidas na Célula de Entrada fosse mais adequada para o alinhamento com a estrutura do R/3, ainda existiria outra questão a ser avaliada: por que a subordinação à área de Contabilidade e não à área de compras? Não foi possível identificar os motivos que levaram a empresa a inserir o setor Célula de Entrada na estrutura da área de Contabilidade. Tal decisão pode estar relacionada à deficiência quanto aos conhecimentos contábeis dos funcionários da célula (e isto seria mais uma conseqüência de problemas com treinamento - FCS). Pode estar relacionada ainda à dificuldade em mudar paradigmas, uma vez que já era de responsabilidade da área de Contabilidade os registros dos materiais adquiridos e como no R/3 essa tornou-se uma atividade fundamental para a qualidade de todas as informações geradas, talvez a área de Contabilidade tenha experimentado certa dificuldade em desligar-se dessas atividades. Pode também ser 
conseqüência desses dois fatores juntos ou ainda pode haver mais fatores envolvidos nessa decisão e que não foram identificados pela pesquisadora.

Por fim, a estrutura do R/3 conduziu a uma visão mais ampla dos processos da empresa, o que proporcionou a conscientização dos funcionários sobre os reflexos de suas atividades nas atividades da Contabilidade.

\subsection{Contabilidade gerencial}

A Contabilidade Gerencial da Empresa 2 passou a ser melhor estruturada devido às ferramentas do R/3, especificamente aquelas disponibilizadas pelo módulo CO. O sistema permitiu a elaboração mais criteriosa de custos, o desenvolvimento de análises gerenciais de custos, a elaboração e acompanhamento de orçamentos e o desenvolvimento de análise de desempenho. Todos esses recursos foram direcionados por uma nova postura da empresa em administrar com base em informações de qualidade, tendo por referência onde e como a empresa está e tendo por direcionamento aonde a empresa deseja chegar. Anteriormente ao R/3, a Empresa 2 já havia tentado implementar essa postura, todavia, o sistema de que dispunha não atendia suas necessidades.

Embora podendo contar com os recursos de informática inerentes ao R/3, a Empresa 2 precisou garantir que os funcionários estivessem comprometidos com seus objetivos e para tanto aliou ao potencial do R/3 a implementação de algumas políticas. Foram alterados os critérios para a elaboração do orçamento, foi adotada a prática de ampla divulgação dos resultados em cada setor da empresa e também implementado um programa de remuneração variável. Foi também introduzida a atividade de suporte de informações aos setores, com o intuito de orientar e esclarecer as dúvidas dos funcionários sobre as atividades relacionadas a essa área. Com essas medidas e o fácil acesso às informações, os funcionários tornaram-se mais comprometidos com a elaboração do orçamento, com as metas de seu setor e com os resultados da empresa. Observa-se nessa situação que, conforme afirma Walton (1993), a implementação de tecnologia avançada por si só é incapaz de garantir vantagens de desempenho significativas.

Quanto ao controle do módulo PP, essa atividade não está relacionada ao foco de negócio da Assessoria de Custos, embora provoque reflexos na atividade de custos. Ao que parece, a 
Assessoria assumiu o módulo PP porque estavam ocorrendo problemas freqüentes enquanto a responsabilidade por este módulo era da área de produção. É provável que se houvesse pessoas adequadamente capacitadas para utilizar esse módulo (FCS), não haveria a necessidade de transferi-lo para a Assessoria de Custos. Não foi possível obter maiores detalhes sobre questões relacionadas à cultura da área de produção e, portanto, não é possível uma análise mais conclusiva sobre este fato.

De forma geral, tanto na Contabilidade Financeira quanto na Contabilidade Gerencial é necessário o uso do programa Excel para a elaboração de relatórios, porque o R/3 apresenta deficiências nesse sentido. Por outro lado, torna-se muito fácil obter os relatórios desejados, tendo em vista que o R/3 possui todos os dados e permite a extração destes e sua transferência para o Excel com muita facilidade.

\subsubsection{Influência da implementação do ERP nos conhecimentos e habilidades}

Com relação aos conhecimentos técnicos (contábil e áreas correlacionadas), foi identificada a necessidade de que os funcionários da área de Contabilidade possuam graduação em Ciências Contábeis como grau mínimo de instrução. Essa necessidade diz respeito ao fato de que, para trabalhar com o R/3, é preciso conhecer com mais profundidade as práticas contábeis bem como sua sustentação teórica, de forma a estar capacitado a realizar as análises e os relacionamentos necessários para obter informação de melhor qualidade.

Sobre os conhecimentos gerais, tendo em vista que a estrutura do R/3 tem a orientação por processos, é fundamental que os funcionários conheçam mais profundamente os processos da empresa e como as atividades influenciam umas as outras, para que eles possam ter mais responsabilidade sobre a informação que disponibilizam e possam estar mais comprometidos com a qualidade da informação gerada pelo sistema.

Quanto aos conhecimentos em tecnologia da informação, além de entender sobre o R/3 é preciso saber operar o Excel, uma vez que o R/3 apresenta deficiência quanto à emissão de relatórios e precisa do apoio do Excel para executar tais atividades.

Quanto às habilidades, o R/3 reforçou a necessidade por habilidades de comunicação e de relacionamento interpessoal. Com o R/3, os funcionários da área de Contabilidade estão 
constantemente em contato com os funcionários dos demais setores para esclarecer dúvidas, orientar quanto aos procedimentos e auxiliar na solução de problemas. Além disso, os treinamentos desenvolvidos na empresa têm como instrutores os próprios funcionários da área de Contabilidade. Outra questão que tornou o relacionamento interpessoal bastante importante foi o fato de ter havido na empresa uma mudança de postura com relação à área de Contabilidade deixar de consertar os erros gerados pelos demais setores. As pessoas acabaram por transferir para os funcionários uma hostilidade provocada por essa mudança de postura e as pessoas da Contabilidade precisaram estar preparadas para solucionar os conflitos que porventura ocorressem.

Com relação às habilidades intelectuais, as alterações nas atividades demandam que os funcionários tenham mais senso crítico e capacidade de análise.

\subsubsection{Considerações finais}

De forma geral, ocorreram algumas alterações na forma de desenvolver as atividades da área de Contabilidade, os registros contábeis foram descentralizados, as atividades relacionadas à Contabilidade Gerencial puderam ser implementadas, pois anteriormente ao R/3, embora houvesse interesse e consciência quanto à sua necessidade, não havia um sistema que permitisse sua realização.

Embora as alterações tenham contribuído sobremaneira para a melhoria do desempenho da Contabilidade e da empresa como um todo, uma observação mais detalhada vai demonstrar que não aconteceram muitas inovações.

Os dirigentes da Empresa 2 têm consciência desse fato e, no entendimento da diretoria sobre as conquistas relacionadas ao $\mathrm{R} / 3$, alguns estágios devem ser considerados. Conforme comentou um dos funcionários, “A primeira preocupação era fazer a empresa funcionar, o foco era no básico, nas funcionalidades básicas - continuar sendo a empresa que era antes. Nesse primeiro momento, não há muito ganho no aspecto gerencial.” A preocupação principal era com os fins e não com os meios.

Num segundo momento, a empresa se preocupou com os ajustes no que foi implantado e que não estava cem por cento. Foi procedida uma revisão da implementação e inicialmente 
buscaram resolver os problemas operacionais e, na seqüência, começaram a explorar o sistema para ver suas funcionalidades gerenciais. Um funcionário afirmou que “A estratégia foi primeiro colocar o sistema para rodar até porque se fosse diferente o tempo de implementação seria bem maior.”

Num terceiro momento, a empresa já resolveu seus problemas, “a casa está em ordem”, e agora tem que evoluir, tendo em vista que a aquisição do sistema foi motivada principalmente pela necessidade por informações gerenciais.

Na época da coleta de dados para esta pesquisa, a empresa encontrava-se entre os estágios 2 e três, ou seja, estava com diversos projetos os quais procuravam resolver os problemas identificados na revisão do sistema (por exemplo, a deficiência com treinamento), e, ao mesmo tempo, já havia iniciado um projeto de implementação da ferramenta BW para atender sua necessidade por relatórios gerenciais. A expectativa era obter, com o BW, informações para apoio à tomada de decisões.

\subsection{Caso 3 - Empresa 3}

A Empresa 3 atua no ramo de comércio de componentes eletrônicos em geral, informática, telefonia, sistemas de cabos profissionais para áudio/vídeo e eletrônica, antenas, lâmpadas e instrumentos musicais, tanto no atacado quanto no varejo.

É formada por três unidades, sendo a matriz e uma filial na região norte do Paraná e uma filial na cidade de São Paulo. Possui um portfólio de aproximadamente 10.000 (dez mil) itens de produtos de tradicionais indústrias nacionais e estrangeiras. Seu faturamento anual, na época da coleta de dados desta pesquisa, era de aproximadamente R\$ 42 milhões (quarenta e dois milhões de reais).

A avaliação dos diversos sistemas ERPs disponíveis no mercado começou no ano de 1999 e a implementação do sistema R/3 da empresa SAP teve início em abril do ano de 2000, com término previsto para outubro de 2000, mas houve atrasos e a entrada em produção aconteceu somente em janeiro do ano de 2001. Os módulos implementados foram MM, SD, FI e CO. 
Foi contratada uma empresa de consultoria parceira da SAP, da cidade de Curitiba-PR, para conduzir este projeto.

Quando a pesquisadora fez o primeiro contato com a Empresa 3 para verificar a possibilidade de coleta de dados naquela organização, questionou-se sobre quais módulos tinham sido implementados e foi confirmado pelo contador da empresa que os módulos FI e CO, foco de interesse desta pesquisa, já estavam implementados.

Todavia, quando a pesquisadora foi à Empresa 3 para coletar os dados verificou que, embora de fato os módulos FI e CO tivessem sido customizados, eles não estavam sendo utilizados.

Aconteceu que, anteriormente ao R/3, a Empresa 3 não possuía uma área de Contabilidade. As atividades referentes à Contabilidade Financeira eram desenvolvidas por um escritório de Contabilidade (atividades terceirizadas) e as atividades relacionadas à Contabilidade Gerencial eram quase inexistentes. As áreas de vendas e compras encaminhavam ao diretor da empresa informações gerenciais sobre suas atividades e a área de informática era responsável pelo levantamento de informações sobre resultados.

Nesse sentido, um dos fatores que motivou a implementação do R/3 foi a possibilidade de desenvolver internamente as atividades relacionadas à Contabilidade. Quando houve a proposta da consultoria, a apresentação demonstrou que a Contabilidade seria on-line, dados reais e a qualquer instante, a partir do início da entrada em produção. Quanto aos problemas que envolviam a implementação da Contabilidade, após diversas discussões com a consultoria, imaginava-se que os problemas poderiam ser solucionados. Não conseguiram visualizar a dimensão dos problemas que enfrentariam para ter a Contabilidade internamente.

O projeto de implementação do $\mathrm{R} / 3$ foi iniciado e não foi contratado um contador para acompanhar o projeto e assumir a Contabilidade da empresa. Em vez disso, um funcionário do escritório de Contabilidade que atendia a empresa foi chamado, e passou algumas horas conversando com os consultores e repassando algumas informações sobre a Contabilidade da Empresa 3. Também foi chamado um funcionário do escritório de advocacia que atendia à empresa para prestar alguns esclarecimentos sobre os tributos relacionados à Empresa 3. Era de responsabilidade desse escritório de advocacia questões referentes à legalidade de tributos e também planejamento tributário. 
Ocorreram muitas situações que prejudicaram a implementação do R/3 e diversos fatores contribuíram para que os módulos FI e CO fossem customizados sem sucesso. Não havia confiabilidade nas informações disponibilizadas por estes módulos. Por seis meses após a entrada em produção do R/3, a empresa tentou realizar a Contabilidade Financeira utilizando o R/3, mas eram muitos os problemas e as inconsistências, e as atividades referentes à Contabilidade Financeira foram novamente terceirizadas ao escritório de Contabilidade. Apenas os módulos SD e MM estavam sendo utilizados de forma satisfatória.

Na época da coleta de dados, a empresa ainda mantinha a Contabilidade Financeira terceirizada, mas havia contratado um contador que, com o auxílio de mais dois funcionários, estava desenvolvendo um trabalho de levantamento das inconsistências do FI com o intuito de resolver os problemas e, finalmente, passar a realizar a Contabilidade Financeira internamente. Até aquele momento ainda não haviam sido contratados serviços de consultoria para acompanhar esse projeto.

Tendo em vista essa realidade, a qual só pôde ser verificada durante a fase de coleta de dados, a Empresa 3 não será utilizada nesta pesquisa, pois não é compatível com os objetivos propostos. Não há possibilidade de comparação entre esta empresa e as demais, relativas aos casos um e dois, já que aquelas estavam de fato utilizando os módulos FI e CO e mantinham as atividades relacionadas à Contabilidade internamente. Esta não possuiu tal estrutura e, portanto, não pode ser comparada às demais.

Dessa forma, embora inicialmente tenha sido prevista a análise e comparação entre três empresas, esta pesquisa contará com dados referentes a dois casos que serão analisados individual e comparativamente. Tais resultados foram ainda comparados aos resultados de outras pesquisas publicadas anteriormente, que não têm exatamente os mesmos objetivos que esta pesquisa, mas cujos resultados, guardadas as restrições e limitações que são apresentadas a seguir, contribuíram para o enriquecimento das análises e a maior consistência da conclusão. Embora com uma quantidade de casos menor que a prevista, a consistência e qualidade dos resultados da pesquisa foram preservadas. 


\subsection{Resultados de Outras Pesquisas Publicadas}

Neste tópico, são apresentados os resultados de algumas pesquisas que relacionam a implementação do ERP com a área de Contabilidade das empresas. Algumas dessas pesquisas foram desenvolvidas no Brasil e outras foram desenvolvidas em outros países.

Todas têm objetivos diferentes, todavia, apresentam algumas informações em comum que, se analisadas conjuntamente, podem evidenciar tendências. Este foi o motivo pelo qual tais resultados foram inseridos no presente trabalho. Acredita-se que, embora os objetivos sejam diferentes e guardadas as restrições quanto ao objeto de estudo e quanto à metodologia adotada, os resultados podem ser comparados para a verificação de tendências.

\subsubsection{Pesquisa realizada por Riccio (2001)}

A pesquisa de Riccio (2001) foi desenvolvida em sete empresas de grande porte e ramos de atividades diferentes, todas usuárias do sistema R/3 da SAP. Estas empresas fazem parte das 500 Maiores e Melhores da Revista Exame e obtiveram faturamento em1999 acima de US\$ 300 milhões (trezentos milhões de dólares).

O objetivo principal da pesquisa foi: "Detectar e analisar as mudanças organizacionais e operacionais ocorridas na área contábil de empresas que implementaram sistemas ERP, pela percepção do contador.” (RICCIO, 2001, p. 9)

O estudo trata de questões referentes ao processo de implementação do ERP, ao sistema propriamente dito (no caso o R/3 da SAP), à estrutura da área de Contabilidade e à imagem e poder da Contabilidade, todas sob a ótica do contador. Foi utilizada a metodologia Estudo de Casos, e os dados foram coletados através de entrevista, com o uso de questionário estruturado. Foram entrevistados os responsáveis pela área de Contabilidade das empresas. Uma das empresas foi objeto do estudo piloto, e as demais (seis) foram analisadas comparativamente.

Quanto à estrutura, em três empresas houve alteração no nome dos cargos, inclusive a criação de um novo cargo em uma das empresas. Não houve detalhamento sobre as alterações nas atividades referentes aos cargos. Em cinco empresas, houve redução do número de 
funcionários da área de Contabilidade. Apenas em uma empresa não houve qualquer alteração.

Quanto às atividades, quatro empresas informaram que não houve criação de novas atividades na Contabilidade e duas informaram que foram criadas novas atividades. Em uma delas, as atividades estão relacionadas a projeto de balanço e relatórios gerenciais e, na outra empresa, as atividades estão relacionadas à auditoria do núcleo de Contabilidade das áreas.

A pesquisa apontou descentralização de atividades da Contabilidade em quatro empresas, mas não detalhou quais atividades. Em todas as empresas houve pelo menos a descentralização dos registros contábeis. O maior impacto foi quanto à redução do tempo gasto para o fechamento mensal, o qual, no caso mais extremo, passou de vinte e cinco/vinte e seis (25/26) dias para três dias. Todas as empresas também relataram uma redução drástica no volume mensal de lançamentos. Uma das empresas menciona que as atividades foram facilitadas. A descrição das mudanças em uma das empresas demonstra as alterações:

O pessoal da Contabilidade virou analista de controladoria dentro da área. Analisam e validam os números gerados pelas outras áreas. [...] a empresa buscou um pessoal de Contabilidade que fosse jovem de espírito, perfil light, que auxiliasse o cliente interno, e que fosse voltado para o negócio. (RICCIO, 2001, p.111)

Especificamente com relação à função do contador, a pesquisa aponta que foi facilitada com o sistema. Em algumas empresas (duas), o contador participa mais do processo de tomada de decisões e, em outra, o contador tem funções mais gerenciais e especializadas.

Quanto à elaboração de relatórios, duas empresas utilizam o Excel e três empresas utilizam outros softwares, e todas elaboram os relatórios gerenciais a partir dos dados extraídos do R/3.

As maiores vantagens apontadas pelos entrevistados foram a integração das informações, o fornecimento instantâneo da informação e o maior controle sobre a operação da Contabilidade. Outras vantagens como maior controle de fornecedores, redução do volume de papéis, maior segurança do sistema, redução do tempo gasto na conciliação bancária, redução das interrupções do sistema por ocasião do fechamento, também foram citadas. 
Em suas considerações, o autor salienta que:

[...] a implementação do $\mathrm{R} / 3$ provocou um conjunto de mudanças que alteraram a maneira de operação da Contabilidade [...] as mudanças foram consideradas pelos contadores como benéficas [...] a descentralização da Contabilidade foi confirmada não somente pelas características de funcionamento do R/3 como pela informação de que o conhecimento contábil foi levado aos vários setores bem como a co-responsabilidade pela execução dos registros pelas diversas áreas da empresa. (Ibid., p.127).

\subsubsection{Pesquisa realizada por Carvalho Filho (2001)}

A pesquisa de Carvalho Filho (2001) foi realizada em oito empresas, sendo quatro ligadas ao Setor de Energia Elétrica e as demais ligadas a diversos setores: Serviços de Telecomunicações, Cartões de Crédito, Comércio Varejista e Iluminação. Destas, seis possuem o ERP da empresa SAP (R/3). Uma possui o ERP da Peoplesoft e uma possui o ERP da Oracle.

Os objetivos da pesquisa foram: identificar o impacto da implantação do ERP na Contabilidade Gerencial e identificar o impacto da implantação do ERP no papel do contador gerencial. Como objetivos específicos buscou coletar informações sobre a implantação do sistema ERP; coletar informações sobre o impacto da implantação do ERP na organização e nos métodos de controle; coletar informações sobre o impacto da implantação do ERP nos métodos contábeis; coletar informações sobre o impacto da implantação do ERP nas atividades do contador gerencial; e coletar informações sobre o impacto da implantação do ERP na qualidade da informação contábil.

A coleta de dados da pesquisa de campo foi através de entrevista, com utilização de um roteiro. Foram entrevistados os responsáveis pela Contabilidade em cada uma das empresas.

O autor apresenta o resultado de três pesquisas realizadas fora do Brasil que envolvem ERP e Contabilidade Gerencial: Fahy e Linch (1999), Paolo Macarrone (2001) e Granlund e Malmi (2000). Estas foram realizadas em empresas que utilizam, na maioria, o software R/3 da SAP e, embora seus objetivos não sejam os mesmos, algumas evidências são comuns entre elas.

De forma resumida, Carvalho Filho (2001, p. 81) apresenta algumas conclusões das pesquisas realizadas fora do Brasil sobre a Contabilidade Gerencial e o papel do contador gerencial: 
a) a maioria das instalações dos sistemas ERP está em desenvolvimento, não sendo possível, portanto, medir em toda a extensão os impactos dessa implantação sobre a empresa e sobre a Contabilidade Gerencial e o papel do Contador Gerencial em particular.

b) embora a implantação dos sistemas tenha trazido melhorias nos sistemas de medição e controle de performance das empresas, essas melhorias não foram significativas.

c) a implantação dos sistemas ERP não induziu as empresas a adotarem técnicas mais sofisticadas de Contabilidade Gerencial. Provavelmente isso esteja ocorrendo em função dos projetos estarem em sua fase inicial(...).

d) o recurso de drill down do sistema tem melhorado significativamente o trabalho do contador gerencial na análise das variações entre valores previstos e realizados. Auxilia, também, os gerentes na análise das causas das variações.

e) a existência de uma base de dados centralizada no ERP facilitou o trabalho dos contadores gerenciais na extração de dados e preparação de relatórios.

f) a possibilidade de extração de relatório ad hoc, diretamente do sistema, reduziu a carga de trabalho e a necessidade de utilização de planilhas.

Na seqüência, o autor apresenta os resultados de sua pesquisa, desenvolvida no Brasil, com empresas que utilizam os softwares de ERP da SAP, Oracle e Peoplesoft. Embora não seja possível generalizar tais resultados, principalmente porque os estudos foram feitos em empresas com implementação recente do ERP, o autor acredita que a pesquisa evidencia tendências. O autor apresenta um sumário das conclusões de sua pesquisa, o qual é evidenciado na seqüência:

a) a implantação do ERP não induz a mudanças nos métodos de controle, mas torna viável a implantação dessas mudanças motivadas por outros fatores externos.

b) as alterações nas funções da Contabilidade Gerencial foram menores e se concentram na implementação de funções que já faziam parte do escopo da área, mas que não eram implementadas por falta de suporte de informática.

c) $\mathrm{O}$ fato dos dados contábeis estarem sendo atualizados em tempo real, nas empresas com implantação de ERP consolidada, provocou uma maior utilização desses dados.

d) As empresas com a implantação do ERP consolidada alteraram os seus critérios de contabilização para atender à necessidade de maior precisão dos dados reclamada pelos usuários da informação contábil.

e) as empresas pesquisadas não introduziram técnicas novas de Contabilidade Gerencial, tais como, Custeio ABC, Balanced Scorecard e Target Cost em função da implantação do ERP.

f) houve uma grande redução de pessoal na área de Contabilidade provocada pela implantação do ERP.

g) Houve uma grande redução do tempo gasto pelo Contador Gerencial na tarefa de preparação de relatórios gerenciais, principalmente nas empresas onde o número de módulos do ERP implantados é maior.

h) o Contador Gerencial passou a exercer também a função de consultor. Além de produzir relatórios, está sendo solicitado, pela gerência, para explicar o porquê das variações de custo, bem como participar do desenvolvimento de soluções.

i) o Contador Gerencial transformou-se, também, em um consultor de informações financeiras, identificando, junto ao usuário, necessidade de alteração de critérios contábeis, bem como novos relatórios, e os implementando no ERP.

j) o Contador Gerencial, para desempenhar melhor o seu papel de consultor, teve que conhecer melhor os processos da empresa.

k) a implantação do ERP possibilitou uma atualização mais rápida dos dados contábeis, o que resultou na melhoria da 'tempestividade' desses dados, fato que contribuiu para o aumento de seu uso.

l) a eliminação, com o uso do ERP, das inconsistências de dados, comuns quando se usa sistemas desintegrados, melhorou a confiança na informação contábil e, conseqüentemente, provocou o aumento de seu uso. (CARVALHO FILHO, 2001, p. 95). 


\subsection{Análise Comparativa}

\begin{tabular}{|c|c|c|c|c|c|}
\hline Tópicos & $\begin{array}{l}\text { Alterações na } \\
\text { Empresa } 1\end{array}$ & $\begin{array}{l}\text { Alterações } \\
\text { Empresa } 2\end{array}$ & $\begin{array}{l}\text { Resultados da } \\
\text { Pesquisa de Riccio }\end{array}$ & $\begin{array}{lr}\text { Resultados } & \text { da } \\
\text { Pesquisa } & \text { dos } \\
\text { autores } & \\
\text { estrangeiros } & \\
\end{array}$ & $\begin{array}{l}\text { Resultados } \\
\text { Pesquisa } \\
\text { Carvalho Filho }\end{array}$ \\
\hline \multirow{6}{*}{ 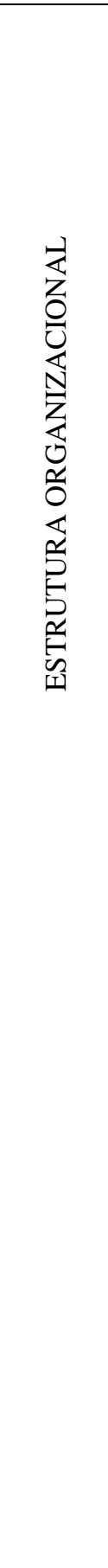 } & $\begin{array}{l}\text { Não houve revisão } \\
\text { ampla da Estrutura } \\
\text { Organizacional na } \\
\text { fase de } \\
\text { implementação. }\end{array}$ & $\begin{array}{l}\text { Houve revisão } \\
\text { ampla da Estrutura } \\
\text { Organizacional na } \\
\text { fase } \\
\text { implementação. }\end{array}$ & Não consta. & Não consta. & Não consta. \\
\hline & $\begin{array}{l}\text { Foi criada uma } \\
\text { área } \\
\text { (Controladoria) } \\
\text { para desenvolver } \\
\text { as atividades da } \\
\text { Contabilidade } \\
\text { Gerencial } \\
\text { relacionadas ao } \\
\text { módulo CO - na } \\
\text { fase de } \\
\text { implementação. }\end{array}$ & $\begin{array}{lr}\text { Foi criada } & \text { uma } \\
\text { área (Assessoria de } \\
\text { Custos) } & \text { para } \\
\text { desenvolver } & \text { as } \\
\text { atividades } & \text { da } \\
\text { Contabilidade } \\
\text { Gerencial } \\
\text { relacionadas } \\
\text { módulo CO } & \text { ao um } \\
\text { ano após } & \text { a } \\
\text { implementação. } & \end{array}$ & Não consta. & Não consta. & Não consta. \\
\hline & $\begin{array}{l}\text { Quando o R/3 foi } \\
\text { implementado, já } \\
\text { existia um setor } \\
\text { para centralizar o } \\
\text { recebimento e } \\
\text { cadastro de } \\
\text { materiais (Pool de } \\
\text { Recebimentos) }\end{array}$ & $\begin{array}{lr}\text { Criação do setor } \\
\text { Célula de Entrada } \\
\text { para centralizar o } \\
\text { recebimento } \\
\text { cadastro } \\
\text { materiais - um ano } \\
\text { após de } \\
\text { implementação. } \\
\end{array}$ & Não consta. & Não consta. & Não consta. \\
\hline & Não houve. & $\begin{array}{l}\text { Transferência do } \\
\text { setor almoxarifado } \\
\text { para outra gerência } \\
-\quad \text { não era } \\
\text { condizente com o } \\
\text { foco de negócio da } \\
\text { Contabilidade. }\end{array}$ & Não consta. & Não consta. & Não consta. \\
\hline & Não houve & \begin{tabular}{lr}
\multicolumn{3}{l}{ Alteração na forma } \\
de agrupar & as \\
atividades & nos \\
setores & da \\
Contabilidade.
\end{tabular} & Não consta. & Não consta. & Não consta. \\
\hline & $\begin{array}{l}\text { Não houve } \\
\text { alteração formal na } \\
\text { estrutura de cargos. }\end{array}$ & \begin{tabular}{lr}
\multicolumn{2}{l}{ Houve alterações } \\
na estrutura de \\
cargos: \\
reagrupamento das \\
atividades \\
cargos em \\
amplos & mais \\
valorização & dom \\
cargos. & \\
\end{tabular} & $\begin{array}{l}\text { Em três empresas } \\
\text { houve alteração no } \\
\text { nome dos cargos e } \\
\text { em uma das } \\
\text { empresas houve a } \\
\text { criação de um } \\
\text { novo cargo }\end{array}$ & Não consta. & Não consta. \\
\hline
\end{tabular}




\begin{tabular}{|c|c|c|c|c|c|c|}
\hline \multicolumn{2}{|c|}{ Tópicos } & $\begin{array}{l}\text { Alterações } \\
\text { Empresa } 1\end{array}$ & $\begin{array}{l}\text { Alterações na } \\
\text { Empresa } 2\end{array}$ & $\begin{array}{l}\text { Resultados da } \\
\text { Pesquisa de Riccio }\end{array}$ & $\begin{array}{lr}\text { Resultados } & \text { da } \\
\text { Pesquisa } & \text { dos } \\
\text { autores } & \\
\text { estrangeiros } & \\
\end{array}$ & $\begin{array}{ll}\text { Resultados } & \text { da } \\
\text { Pesquisa } & \text { de } \\
\text { Carvalho Filho } & \end{array}$ \\
\hline \multirow{2}{*}{\multicolumn{2}{|c|}{ 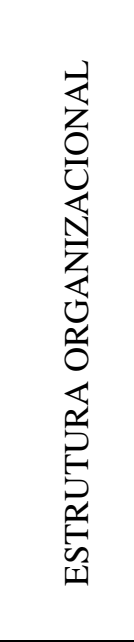 }} & $\begin{array}{l}\text { Não houve redução } \\
\text { do número de } \\
\text { funcionários. }\end{array}$ & $\begin{array}{l}\text { Houve redução no } \\
\text { número } \\
\text { funcionários. }\end{array}$ & $\begin{array}{l}\text { Em cinco empresas } \\
\text { houve redução no } \\
\text { número de } \\
\text { funcionários e em } \\
\text { apenas uma não } \\
\text { houve alteração. }\end{array}$ & Não consta. & $\begin{array}{l}\text { Houve redução no } \\
\text { número } \\
\text { funcionários. }\end{array}$ \\
\hline & & $\begin{array}{lr}\text { Necessidade } & \text { de } \\
\text { transferência } & \text { de } \\
\text { pessoas } & \text { com } \\
\text { conhecimento } & \\
\text { contábil para } & \text { o } \\
\text { setor } & \text { de } \\
\text { recebimento } & \text { e } \\
\text { cadastro } & \text { de } \\
\text { materiais. (Pool de } \\
\text { Recebimento). }\end{array}$ & $\begin{array}{lr}\text { Necessidade } & \text { de } \\
\text { transferência } & \text { de } \\
\text { pessoas } & \text { com } \\
\text { conhecimento } & \\
\text { contábil para } & \text { o } \\
\text { setor } & \text { de } \\
\text { recebimento } & \text { e } \\
\text { cadastro } & \text { de } \\
\text { materiais. (Célula } \\
\text { de Entrada). }\end{array}$ & Não consta. & Não consta. & Não consta. \\
\hline \multirow[t]{4}{*}{ 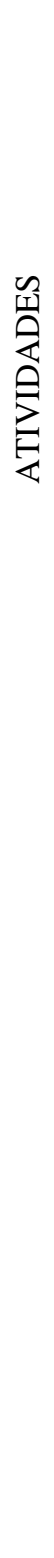 } & \multirow{4}{*}{ 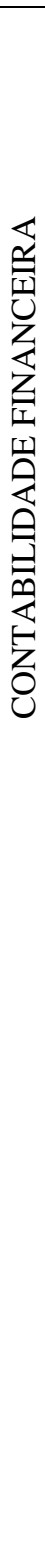 } & \begin{tabular}{l}
\multicolumn{2}{l}{ Descentralização } \\
da maior parte das \\
atividades \\
relacionadas ao \\
registro contábil - \\
alguns registros \\
contábeis \\
referentes \\
despesas diversas \\
ainda a \\
executados na \\
Contabilidade. \\
\end{tabular} & $\begin{array}{l}\text { Descentralização } \\
\text { das atividades } \\
\text { relacionadas ao } \\
\text { registro contábil. }\end{array}$ & $\begin{array}{l}\text { Em todas as } \\
\text { empresas (seis) } \\
\text { houve } \\
\text { descentralização } \\
\text { das atividades da } \\
\text { Contabilidade. Em } \\
\text { duas delas, pelo } \\
\text { menos os registros } \\
\text { contábeis, foram } \\
\text { descentralizados. }\end{array}$ & Não consta. & Não consta. \\
\hline & & $\begin{array}{l}\text { Foram mantidos na } \\
\text { Contabilidade } \\
\text { alguns registros } \\
\text { contábeis } \\
\text { necessários ao } \\
\text { fechamento do } \\
\text { período. }\end{array}$ & \begin{tabular}{ll}
\multicolumn{2}{l}{ Foram mantidos na } \\
Contabilidade \\
alguns registros \\
contábeis \\
necessários ao \\
fechamento do \\
período. \\
\end{tabular} & Não consta. & Não consta. & Não consta. \\
\hline & & $\begin{array}{lr}\text { Facilitou } & \text { a } \\
\text { execução } & \text { das } \\
\text { atividades } \\
\text { mantidas } \\
\text { Contabilidade. (ex: } \\
\text { apuração na } \\
\text { impostos, de } \\
\text { fechamento } \\
\text { contábil, controle } \\
\text { do imobilizado } \\
\text { etc). }\end{array}$ & 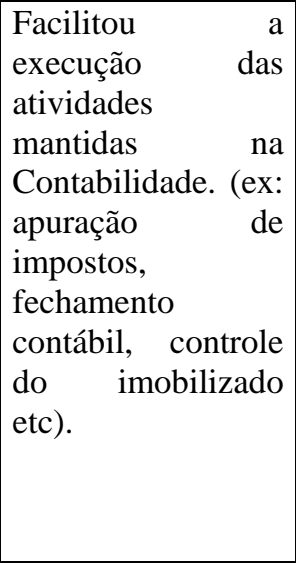 & $\begin{array}{l}\text { Todas as empresas } \\
\text { (seis) apresentaram } \\
\text { redução no tempo } \\
\text { de execução das } \\
\text { atividades } \\
\text { relacionadas ao } \\
\text { fechamento do } \\
\text { período, redução } \\
\text { no volume mensal } \\
\text { de lançamentos, e } \\
\text { duas das empresas } \\
\text { mencionaram que } \\
\text { as atividades foram } \\
\text { facilitadas. }\end{array}$ & Não consta. & Não consta. \\
\hline & & $\begin{array}{lr}\text { A atividade de } \\
\text { conferência dos } \\
\text { registros contábeis } \\
\text { executados pelas } \\
\text { outras áreas foi } \\
\text { intensificada. }\end{array}$ & $\begin{array}{l}\text { A atividade de } \\
\text { conferência dos } \\
\text { registros contábeis } \\
\text { foi reduzida. }\end{array}$ & Não consta. & Não consta. & Não consta. \\
\hline
\end{tabular}




\begin{tabular}{|c|c|c|c|c|c|c|}
\hline \multicolumn{2}{|c|}{ Tópicos } & $\begin{array}{ll}\text { Alterações } & \text { na } \\
\text { Empresa } 1 & \end{array}$ & $\begin{array}{ll}\text { Alterações } & \text { na } \\
\text { Empresa } 2 & \end{array}$ & $\begin{array}{l}\text { Resultados da } \\
\text { Pesquisa de Riccio }\end{array}$ & $\begin{array}{|lr|}\text { Resultados } & \text { da } \\
\text { Pesquisa } & \text { dos } \\
\text { autores } & \\
\text { estrangeiros } & \\
\end{array}$ & $\begin{array}{|ll|}\text { Resultados } & \text { da } \\
\text { Pesquisa } & \text { de } \\
\text { Carvalho Filho } & \end{array}$ \\
\hline \multirow{6}{*}{ 窟 } & \multirow{6}{*}{ 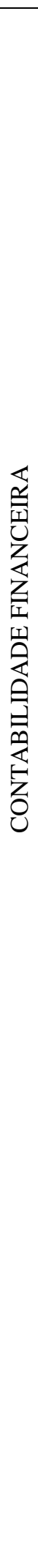 } & $\begin{array}{l}\text { A atividade de } \\
\text { análise } \\
\text { intensificada } \\
\text { (relatórios, razões, } \\
\text { livros for fiscais, } \\
\text { demonstrações, } \\
\text { entre outros). }\end{array}$ & $\begin{array}{l}\text { A atividade de } \\
\text { análise foi } \\
\text { intensificada } \\
\text { (relatórios, razões, } \\
\text { livros fiscais, } \\
\text { demonstrações, } \\
\text { entre outros). }\end{array}$ & Não consta. & Não consta. & Não consta. \\
\hline & & Não houve. & \begin{tabular}{|lr} 
Introduziu & a \\
atividade & de \\
treinamento & \\
referente & aos \\
conceitos e & às \\
práticas contábeis \\
aos r demais \\
funcionários da \\
empresa. \\
\end{tabular} & Não consta. & Não consta. & Não consta. \\
\hline & & \begin{tabular}{|lr} 
Promoveu & a \\
valorização & das \\
atividades & \\
relacionadas & ao \\
controle & do \\
imobilizado. & \\
\end{tabular} & \begin{tabular}{|lr} 
Promoveu & a \\
valorização & das \\
atividades & \\
relacionadas & ao \\
controle & do \\
imobilizado. & \\
\end{tabular} & Não consta. & Não consta. & Não consta. \\
\hline & & $\begin{array}{lr}\text { Introduziu } & \text { a } \\
\text { atividade } & \text { de } \\
\text { suporte } & \text { de } \\
\text { informações aos } & \text { and } \\
\text { demais } & \\
\text { funcionários sobre } \\
\text { as r práticas } \\
\text { contábeis r - } \\
\text { principalmente } \\
\text { legislação e contas } \\
\text { contábeis. } \\
\end{array}$ & \begin{tabular}{lrr} 
Introduziu & a \\
atividade & de \\
suporte r & de \\
informações & aos \\
demais & \\
funcionários & sobre \\
as & práticas \\
contábeis r & - \\
principalmente & \\
legislação e contas \\
\multicolumn{2}{l}{ contábeis. } \\
\end{tabular} & Não consta. & Não consta. & Não consta. \\
\hline & & $\begin{array}{ll}\text { Promoveu } & \text { a } \\
\text { conscientização } \\
\text { dos funcionários } \\
\text { da empresa sobre } \\
\text { da reflexos de suas } \\
\text { atividades ras } \\
\text { atividades ras } \\
\text { Contabilidade. } \\
\end{array}$ & $\begin{array}{l}\text { Promoveu a } \\
\text { conscientização } \\
\text { dos funcionários } \\
\text { da empresa sobre } \\
\text { os reflexos das } \\
\text { atividades destes } \\
\text { nas atividades da } \\
\text { Contabilidade. }\end{array}$ & Não consta. & Não consta. & Não consta. \\
\hline & & \begin{tabular}{llr}
\multicolumn{3}{|c}{ Exigiu uso intenso } \\
do $\quad$ Excel & para \\
realizar & alguns \\
controles e & para \\
elaboração & de \\
relatórios. & \\
\end{tabular} & \begin{tabular}{lrr}
\multicolumn{3}{|c}{ Exigiu uso intenso } \\
do Excel & para \\
realizar & alguns \\
controles er & para \\
elaboração & de \\
relatórios. &
\end{tabular} & 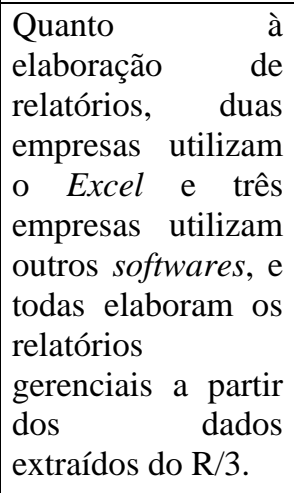 & Não consta. & Não consta. \\
\hline
\end{tabular}




\begin{tabular}{|c|c|c|c|c|c|c|}
\hline \multicolumn{2}{|c|}{ Tópicos } & $\begin{array}{l}\text { Alterações } \\
\text { Empresa } 1\end{array}$ & $\begin{array}{l}\text { Alterações } \\
\text { Empresa } 2\end{array}$ & $\begin{array}{l}\text { Resultados da } \\
\text { Pesquisa de Riccio }\end{array}$ & 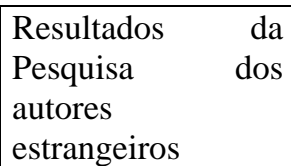 & $\begin{array}{ll}\text { Resultados } & \text { da } \\
\text { Pesquisa } & \text { de } \\
\text { Carvalho Filho } & \end{array}$ \\
\hline \multirow{5}{*}{ 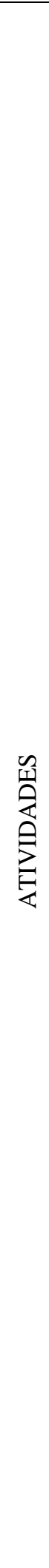 } & \multirow{5}{*}{ 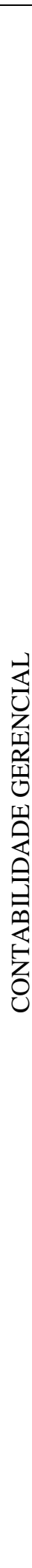 } & $\begin{array}{lr}\text { Permitiu } & \text { a } \\
\text { elaboração } & \text { mais } \\
\text { criteriosa } & \text { dos } \\
\text { custos e a } & \text { análise } \\
\text { gerencial } & \text { dos } \\
\text { custos. } & \end{array}$ & $\begin{array}{lr}\text { Permitiu } & \text { a } \\
\text { elaboração } & \text { mais } \\
\text { criteriosa } & \text { dos } \\
\text { custos e a } & \text { análise } \\
\text { gerencial } & \text { dos } \\
\text { custos. } & \\
\end{array}$ & \multirow{5}{*}{$\begin{array}{l}\text { Das seis empresas, } \\
\text { em apenas duas } \\
\text { houve criação de } \\
\text { novas atividades. } \\
\text { Em uma delas, a } \\
\text { atividade refere-se } \\
\text { a projeto de } \\
\text { balanço e } \\
\text { relatórios } \\
\text { gerenciais e, na } \\
\text { outra, refere-se à } \\
\text { auditoria do núcleo } \\
\text { de Contabilidade } \\
\text { das áreas. }\end{array}$} & $\begin{array}{l}\text { Não houve adoção } \\
\text { de técnicas mais } \\
\text { sofisticadas } \\
\text { relacionadas } \\
\text { custos (ABC). }\end{array}$ & $\begin{array}{l}\text { Houve alteração } \\
\text { nos critérios de } \\
\text { contabilziação } \\
\text { (critérios de rateio } \\
\text { de custos). } \\
\text { Não foram } \\
\text { introduzidas novas } \\
\text { técnicas } \\
\text { Contabilidade } \\
\text { Gerencial } \\
\text { relacionadas } \\
\text { custos, tais como } \\
\text { ABC e Target } \\
\text { Cost. }\end{array}$ \\
\hline & & $\begin{array}{lr}\text { Facilitou } & \text { a } \\
\text { execução } & \text { das } \\
\text { atividades } & \\
\text { relacionadas } \\
\text { elaboração à } \\
\text { acompanhamento } \\
\text { de orçamentos. }\end{array}$ & $\begin{array}{ll}\text { Permitiu a } & \text { a } \\
\text { elaboração } & \text { e } \\
\text { acompanhamento } \\
\text { de orçamentos. }\end{array}$ & & $\begin{array}{lr}\text { O recurso drill } \\
\text { down facilitou o } \\
\text { acompanhamento e } \\
\text { análise r das } \\
\text { variações }\end{array}$ & 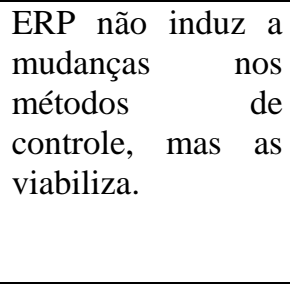 \\
\hline & & $\begin{array}{l}\text { Facilitou a } \\
\text { execução das } \\
\text { atividades } \\
\text { relacionadas ao } \\
\text { desenvolvimento } \\
\text { de análise de } \\
\text { desempenho. }\end{array}$ & $\begin{array}{ll}\text { Permitiu } & \text { a } \\
\text { execução } & \text { das } \\
\text { atividades } & \\
\text { relacionadas ao } \\
\text { desenvolvimento } \\
\text { de análise de } \\
\text { desempenho. }\end{array}$ & & $\begin{array}{l}\text { Houve melhorias } \\
\text { nos sistemas de } \\
\text { medição } \\
\text { controle, mas estas } \\
\text { não foram } \\
\text { significativas. Não } \\
\text { houve adoção de } \\
\text { técnicas mais } \\
\text { sofisticadas como, } \\
\text { por exemplo, o } \\
\text { Balanced } \\
\text { Scorecard }\end{array}$ & $\begin{array}{lr}\text { Não foram } \\
\text { introduzidas } \\
\text { técnicas } \\
\text { Contabilidade } \\
\text { Gerencial } \\
\text { relacionadas } \\
\text { análise } \\
\text { desempenho, como } \\
\text { por exemplo o } \\
\text { Balanced } \\
\text { Scorecard. }\end{array}$ \\
\hline & & $\begin{array}{lr}\text { Intensificou } & \text { a } \\
\text { atividade } & \text { de } \\
\text { suporte } & \text { de } \\
\text { informações aos } & \\
\text { demais } & \\
\text { funcionários } & \\
\text { principalmente } & \\
\text { sobre orçamentos e } \\
\text { custos. }\end{array}$ & \begin{tabular}{lr} 
Introduziu & a \\
atividade & de \\
suporte & de \\
informações & aos \\
demais & \\
funcionários & sobre \\
\multicolumn{2}{l}{ orçamentos, custos } \\
e análise r de \\
desempenho.
\end{tabular} & & Não consta. & Não consta. \\
\hline & & Não houve. & $\begin{array}{l}\text { Introduziu } \\
\text { atividade a de } \\
\text { planejamento de } \\
\text { produção (módulo } \\
\text { PP) - essa } \\
\text { atividade não é } \\
\text { condizente com o } \\
\text { foco de negócio da } \\
\text { área referente à } \\
\text { Contabilidade } \\
\text { Gerencial }\end{array}$ & & Não consta. & Não consta. \\
\hline
\end{tabular}




\begin{tabular}{|c|c|c|c|c|c|c|}
\hline \multicolumn{2}{|c|}{ Tópicos } & $\begin{array}{ll}\text { Alterações } & \text { na } \\
\text { Empresa } 1 & \end{array}$ & $\begin{array}{ll}\text { Alterações } & \text { na } \\
\text { Empresa } 2 & \end{array}$ & $\begin{array}{l}\text { Resultados da } \\
\text { Pesquisa de Riccio }\end{array}$ & \begin{tabular}{|lr} 
Resultados & da \\
Pesquisa & dos \\
autores & \\
estrangeiros & \\
\end{tabular} & \begin{tabular}{|lr} 
Resultados & da \\
Pesquisa & de \\
Carvalho Filho & \\
\end{tabular} \\
\hline \multirow[b]{2}{*}{ 至 } & & $\begin{array}{lr}\text { Exigiu uso intenso } \\
\text { do Excel para } \\
\text { realizar } & \text { alguns } \\
\text { controles e } & \text { para } \\
\text { elaboração } & \text { de } \\
\text { relatórios. } & \end{array}$ & 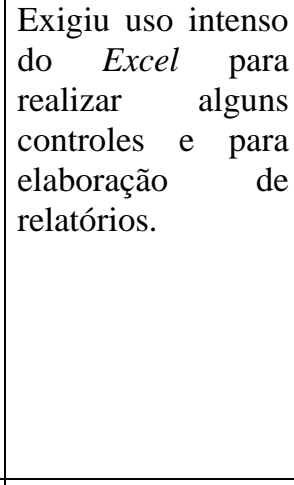 & & $\begin{array}{ll}\text { A base de } & \text { dados } \\
\text { única de } & \text { ERP } \\
\text { facilitou a extração } \\
\text { e elaboração de } \\
\text { relatórios. } \\
\text { Além } & \\
\text { relatórios ad disso, } \\
\text { facilitaram } & \text { hoc } \\
\text { reduziram } & \text { a } \\
\text { atividade } & \text { de } \\
\text { elaboração } & \text { de } \\
\text { planilhas. } & \\
\end{array}$ & $\begin{array}{l}\text { Houve redução no } \\
\text { tempo de execução } \\
\text { das atividades } \\
\text { relacionadas à } \\
\text { elaboração } \\
\text { relatórios } \\
\text { gerenciais. }\end{array}$ \\
\hline & 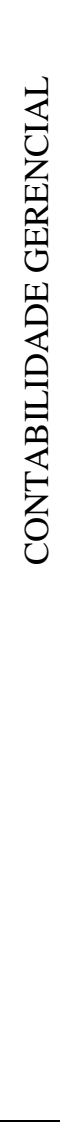 & 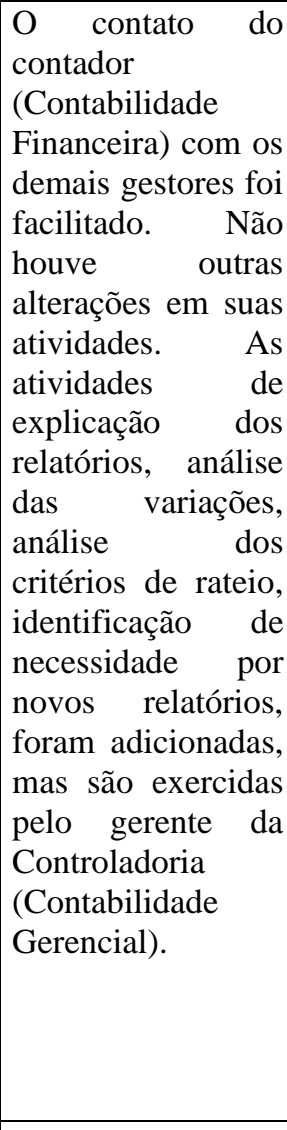 & 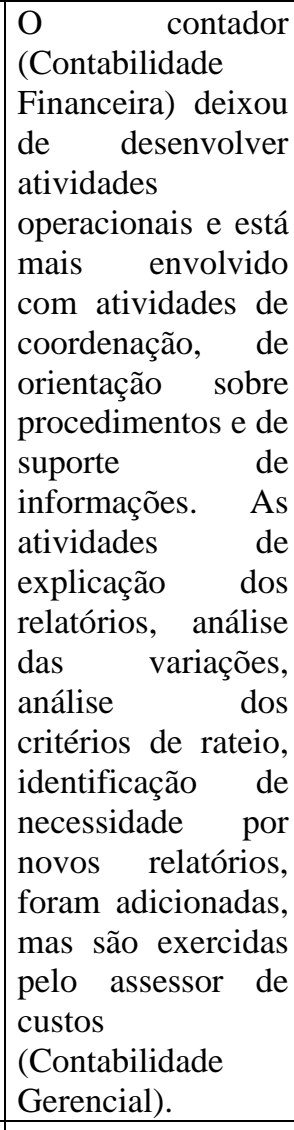 & 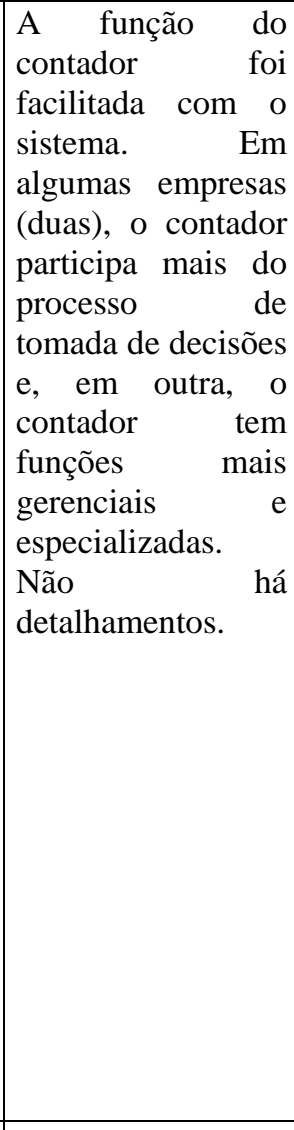 & Não consta. & \begin{tabular}{|lr} 
Contador \\
Gerencial passou a \\
desenvolver \\
atividades \\
consultor de \\
explicação dos \\
relatórios, análise \\
das variações, \\
análise & dos \\
critérios de rateio, \\
identificação de \\
necessidade de \\
novos relatórios.
\end{tabular} \\
\hline \multirow{3}{*}{\multicolumn{2}{|c|}{ 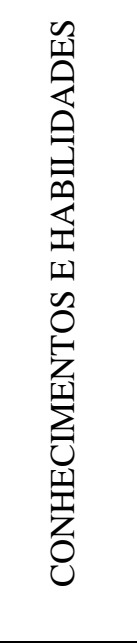 }} & $\begin{array}{l}\text { Graduação em } \\
\text { Ciências Contábeis } \\
\text { como grau mínimo } \\
\text { de instrução ou } \\
\text { experiência r na } \\
\text { área. }\end{array}$ & $\begin{array}{l}\text { Graduação em } \\
\text { Ciências Contábeis } \\
\text { como grau mínimo } \\
\text { de instrução. }\end{array}$ & Não consta. & Não consta. & Não consta. \\
\hline & & $\begin{array}{l}\text { Exigiu } \\
\text { conhecimento } \\
\text { aprofundado sobre } \\
\text { os processos da } \\
\text { empresa. }\end{array}$ & $\begin{array}{l}\text { Exigiu } \\
\text { conhecimento } \\
\text { aprofundado sobre } \\
\text { os processos da } \\
\text { empresa. }\end{array}$ & Não consta. & \begin{tabular}{lr}
\multicolumn{2}{c}{ Contador gerencial } \\
em seu papel de \\
consultor, \\
necessita conhecer \\
melhor $\quad$ os \\
processos & da \\
empresa.
\end{tabular} & Não consta. \\
\hline & & $\begin{array}{l}\text { Exigiu } \\
\text { conhecimento do } \\
\text { Excel. }\end{array}$ & $\begin{array}{l}\text { Exigiu } \\
\text { conhecimento do } \\
\text { Excel. }\end{array}$ & Não consta. & Não consta. & Não consta. \\
\hline
\end{tabular}




\begin{tabular}{|c|c|c|c|c|c|}
\hline Tópicos & $\begin{array}{l}\text { Alterações } \\
\text { Empresa } 1\end{array}$ & $\begin{array}{ll}\text { Alterações } & \text { na } \\
\text { Empresa } 2 & \end{array}$ & $\begin{array}{l}\text { Resultados da } \\
\text { Pesquisa de Riccio }\end{array}$ & \begin{tabular}{|lr} 
Resultados & da \\
Pesquisa & dos \\
autores & \\
estrangeiros & \\
\end{tabular} & \begin{tabular}{|ll} 
Resultados & da \\
Pesquisa & de \\
Carvalho Filho &
\end{tabular} \\
\hline \multirow{3}{*}{ 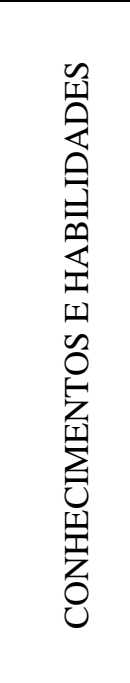 } & $\begin{array}{l}\text { Exigiu } \\
\text { conhecimento do } \\
\text { inglês (idioma). }\end{array}$ & $\begin{array}{ll}\text { Não houve a } & \text { a } \\
\text { necessidade } & \text { de } \\
\text { conhecimento do } & \text { inglês (idioma). }\end{array}$ & Não consta. & Não consta. & Não consta. \\
\hline & $\begin{array}{lr}\text { Reforçou } & \text { a } \\
\text { necessidade } & \text { pelas } \\
\text { habilidades } & \\
\text { intelectuais } & \text { de } \\
\text { senso crítico } & \text { e } \\
\text { capacidade } & \text { de } \\
\text { análise. } & \\
\end{array}$ & $\begin{array}{lr}\text { Reforçou } & \text { a } \\
\text { necessidade } & \text { pelas } \\
\text { habilidades } & \\
\text { intelectuais } & \text { de } \\
\text { senso crítico } & \text { e } \\
\text { capacidade } & \text { de } \\
\text { análise. } & \end{array}$ & Não consta. & Não consta. & Não consta. \\
\hline & $\begin{array}{lr}\text { Reforçou } & \text { a } \\
\text { necessidade } & \text { por } \\
\text { habilidades } & \text { de } \\
\text { comunicação e } & \text { de } \\
\text { relacionamento } & \\
\text { interpessoal. } & \\
\end{array}$ & 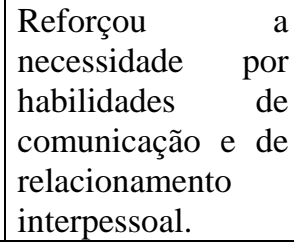 & Não consta. & Não consta. & Não consta. \\
\hline
\end{tabular}

\subsubsection{Alterações relacionadas à estrutura organizacional}

Quanto às mudanças relacionadas à estrutura organizacional, a Empresa 1 não procedeu à revisão ampla da sua estrutura e verificou-se que na área de Contabilidade não houve alterações na forma de agrupar as atividades e na estrutura de cargos. Já na Empresa 2, que procedeu à revisão ampla da estrutura organizacional, ocorreram alterações na área de Contabilidade quanto à forma de agrupar as atividades e quanto à estrutura de cargos. Isso pode ser uma indicação de que existe uma relação entre essas variáveis, pois dificilmente uma empresa se dedicaria a rever, de forma isolada, se as atividades estão agrupadas de forma adequada nos setores ou se a nomenclatura dos cargos está condizente com as atividades que ele representa ou, ainda, se existe uma forma mais adequada de agrupar as atividades nos cargos, entre outros. Esse tipo de avaliação, normalmente, faz parte de uma revisão mais ampla, pois embora o alinhamento desses fatores com o novo sistema seja desejável, e sua ausência possa trazer alguma insatisfação por parte dos funcionários ou até perda de eficiência, é possível realizar todas as atividades do dia-a-dia sem que elas aconteçam. A pesquisa realizada por Riccio (2001) evidencia que houve alterações nos cargos em quatro das seis empresas.

Por outro lado, podem existir situações em que algumas alterações precisam ser executadas independente de uma revisão geral na estrutura, visto que a melhor utilização do R/3 depende dessas mudanças. Como exemplo, é possível citar a criação de uma área que agrupa as 
atividades desenvolvidas através do módulo CO, a qual na Empresa 1 foi denominada Controladoria e na Empresa 2, Assessoria de Custos. A Empresa 1, embora não tenha procedido uma revisão geral da estrutura, percebeu a necessidade da criação desse setor e realizou essa alteração já na fase de implementação. Já a Empresa 2, que fez a revisão geral da estrutura, não percebeu essa necessidade na fase de implementação e só realizou as mudanças um ano após, ou seja, a mudança sempre foi necessária, apenas não havia sido percebida, pois se assim o fosse, não haveria problemas em implementá-la já que houve a revisão ampla da estrutura.

Outra alteração observada está relacionada à criação um setor que centraliza o recebimento e cadastro de materiais. Na Empresa 1, esse setor foi denominado Pool de Recebimentos e já existia quando o R/3 foi implementado, pois foi criado por uma necessidade da área de suprimentos para atender a logística da empresa. Quando o R/3 foi implementado, percebeuse a necessidade de ter pessoas com conhecimento contábil para executar a atividade de cadastro de materiais, e decidiu-se transferir duas pessoas da área de Contabilidade para o Pool de Recebimentos. Na Empresa 2 o setor de recebimento e cadastro de materiais foi denominado Célula de Entrada e sua criação ocorreu um ano após a implementação do R/3, para atender a uma necessidade gerada por este sistema. Quando o R/3 foi implementado, as atividades inerentes a este setor eram descentralizadas para as diversas áreas de compras existentes na Empresa 2, mas como o R/3 trouxe a necessidade de pessoas com conhecimento contábil para executar a atividade de cadastro de materiais e, não havendo a possibilidade de transferência de funcionários da área de Contabilidade, pois o número de pessoas era insuficiente, decidiu-se centralizar as atividades na Célula de Entrada. Este setor recebeu apenas uma pessoa com conhecimento contábil e os demais funcionários foram transferidos da área de compras e realizaram treinamento sobre as práticas contábeis.

Nesse sentido, considerando que a estrutura do R/3 prevê que no momento do cadastro dos materiais devem ser inseridos grande volume de dados, tanto financeiros quanto qualitativos, os quais serão utilizados por todos os módulos do sistema; considerando que nesse momento também deve ser realizado o registro contábil, inclusive envolvendo legislação; parece evidente a necessidade de que as pessoas envolvidas com as referidas atividades tenham conhecimento sobre Contabilidade e sobre como operacionalizar a Contabilidade no R/3. Dessa forma, a alteração necessária não é especificamente a criação de um setor que centralize as atividades de recebimento e cadastro de materiais, e sim que as pessoas 
responsáveis por realizar tais atividades tenham conhecimento contábil. Nas empresas em questão, como não havia pessoas com conhecimento contábil para atender a essa necessidade, e devido à escassez de tempo para a realização de treinamento, aliada à complexidade das atividades, optou-se por centralizar as atividades.

Ocorreu uma situação específica na Empresa 2, relacionada à estrutura organizacional da área de Contabilidade: a transferência do setor de almoxarifado para a área de suprimentos. Essa alteração não foi motivada pelo $\mathrm{R} / 3$, já que havia sido identificado que o almoxarifado não deveria fazer parte da área de Contabilidade e sim de suprimentos, antes da implementação do R/3. Todavia, a oportunidade de mudanças trazida pelo R/3 foi aproveitada para realizar essa alteração.

\subsubsection{Alterações relacionadas às atividades}

Sobre as alterações nas atividades, conforme evidenciado no item 4.1.4, na Empresa 1, erros freqüentes nos registros contábeis executados pelas demais áreas da empresa ocorriam e prejudicavam as atividades da área de Contabilidade. Para resolver esse problema, a postura adotada, que é mais conservadora e centralizadora, foi manter na área de Contabilidade a execução de todos os registros contábeis possíveis e intensificar a atividade de conferência dos registros contábeis através dos documentos de origem. Já na Empresa 2, conforme evidenciado no item 4.2.4, erros freqüentes também aconteciam e também prejudicavam as atividades da área de Contabilidade, todavia, a postura adotada foi diferente. Decidiu-se intensificar o treinamento sobre as práticas contábeis para reduzir os erros, e manter a proposta inicial que prevê que os erros devem ser corrigidos em sua origem, e não pela área de Contabilidade, ou seja, todo o suporte de informações é oferecido pela área de Contabilidade, mas cada pessoa deve ser responsável pelos seus acertos e erros. Foram mantidos na área de Contabilidade apenas os registros contábeis necessários ao fechamento do período.Verifica-se que a postura adotada pela Empresa 2 está mais alinhada à proposta do R/3 para as atividades da área de Contabilidade, ou seja, a distribuição dos registros contábeis para as “pontas” e a substituição dessas atividades por outras relacionadas a análises e suporte de informações. 
Essa diferença de postura pode ter influenciado na quantidade de pessoas alocadas na Contabilidade, tendo em vista que, na Empresa 1, houve a manutenção do volume de atividades executadas na área de Contabilidade e também a manutenção do número de funcionários nessa área; e, na Empresa 2, houve a redução do volume de atividades, acompanhada pela redução do número de funcionários. A pesquisa desenvolvida por Riccio (2001) evidencia que houve descentralização das atividades da Contabilidade, ao menos em relação aos registros contábeis e que, com exceção de uma empresa, houve também redução do número de funcionários. Já a pesquisa desenvolvida por Carvalho Filho (2001) evidencia redução no número funcionários na área de Contabilidade, embora não apresente informações sobre o volume de atividades.

É importante salientar que, tanto para a Empresa 1 quanto para a Empresa 2, como conseqüência da descentralização dos registros contábeis, foi adicionada à área de Contabilidade a atividade de suporte de informações aos demais funcionários da empresa. Sobre as atividades de análise, elas já existiam, mas em virtude da redução de algumas atividades e da maior facilidade e agilidade em executar outras, foi disponibilizado mais tempo para que as análises fossem feitas tanto no sentido de acompanhar a realização das atividades que foram descentralizadas como no sentido de melhorar a qualidade das informações geradas na área de Contabilidade. Especificamente na Empresa 2, devido à postura adotada de não assumir os erros vindos de outros setores, mas intensificar os treinamentos para capacitar melhor as pessoas que executam os registros contábeis, a atividade de instrutor em treinamentos foi adicionada à área de Contabilidade.

Outra alteração identificada foi quanto à forma de executar as atividades que foram mantidas na área de Contabilidade. O R/3 facilitou e agilizou a execução das mesmas. Por um lado, essa mudança é conseqüência da descentralização dos registros e, por outro lado, é conseqüência do avanço em tecnologia de informação. Como exemplos, pode-se citar a redução de tempo de execução do fechamento contábil, a maior facilidade na apuração dos impostos (com exceção da apuração do ICMS na Empresa 2 que apresentou problemas na parametrização e agora necessita de apoio do programa Excel para ser realizada), a maior facilidade para executar controle do imobilizado etc. Essas alterações quanto à forma de executar as atividades também promovem a redução do número de funcionários. A pesquisa desenvolvida por Riccio (2001) também menciona que algumas atividades da Contabilidade foram facilitadas e agilizadas com o R/3. 
Em ambas as empresas, a atividade de controle do imobilizado foi valorizada. Sabe-se que os sistemas de informação dessas empresas, anteriores ao $\mathrm{R} / 3$, não ofereciam recursos relacionados à tecnologia de informação que possibilitava adequada visualização e controle dos bens existentes. Por sua vez, o R/3 disponibiliza recursos que permitem a visualização dos bens existentes em cada setor, além de facilitar a realização das operações de aquisições, de vendas, de transferências entre setores e de baixas dos bens, inclusive da atividade de inventário. Todavia, não se pode concluir que a presença do $\mathrm{R} / 3$, por si, promova a valorização dessa atividade. Aliados a esse fator, dois outros fatores devem ser considerados:

a) se a empresa já possui um sistema de informação que permite adequada visualização e controle dos bens existentes, pode ocorrer de o R/3 facilitar a execução dessas atividades, mas é improvável que promova sua valorização, pois os funcionários já podiam perceber o valor dessa atividade com o sistema anterior;

b) talvez não tenha sido o fato de as informações passarem a existir dentro da empresa que valorizou a atividade de imobilizado, mas sim o fato de essas informações terem começado a ser utilizadas. Como exemplo, as atividades de orçamento e análise de desempenho foram valorizadas, e como as informações referentes a imobilizado são utilizadas para elaborar essas duas ferramentas, essas informações também passaram a ser valorizadas.

Quanto à atividade de elaboração de custo, em ambas as empresas, esta já era realizada antes da implementação do R/3. Todavia, com este sistema, passou a ser desenvolvida de forma mais criteriosa, mais detalhada, com informações disponíveis por centros de custos e os rateios sendo realizados em bases mais adequadas. A atividade de análise gerencial de custos, também para a Empresa 1 e para a Empresa 2, já era executada, mas pôde contar com maior riqueza de detalhes nas informações, visto que o R/3 proporciona análises sob diversos aspectos (análise multidimensional). Os resultados das pesquisas de Carvalho Filho (2001) e dos autores estrangeiros (FAHY; LINCH, 1999; MACARRONE, 2001; GRANLUND; MALMI, 2000) também demonstram ter havido alterações quanto aos critérios de custos. Além disso, da mesma forma que nas empresas 1 e 2 deste estudo, evidenciam que não foram adotadas técnicas mais sofisticadas relacionadas a custos como, por exemplo, o ABC. 
Com relação às atividades relacionadas a orçamento e análise de desempenho, na Empresa 1, estas já eram realizadas. Com o $\mathrm{R} / 3$, tais atividades passaram a contar com recursos tecnológicos que facilitaram sua execução. Já na Empresa 2, tais atividades, embora existissem, não eram realizadas a contento, não proporcionavam informações de qualidade e, portanto, não eram utilizadas. Com o R/3, a Empresa 2 passou a elaborar e controlar o orçamento de forma mais consistente, o que promoveu a valorização e utilização dessa ferramenta. Da mesma forma, a atividade de análise de desempenho passou a ser desenvolvida de maneira mais adequada, inclusive sendo a base de um programa de remuneração variável que procura incentivar o comprometimento dos funcionários. Sendo assim, em especial a Empresa 2 mas também a Empresa 1 experimentaram um ganho em relação às atividades de orçamento e análise de desempenho. Os resultados das pesquisas de Carvalho Filho (2001) e dos autores estrangeiros (FAHY; LINCH, 1999; MACARRONE, 2001; GRANLUND; MALMI, 2000) também apresentam melhorias quanto às atividades de orçamento e análise de desempenho, todavia, salientam que não foram introduzidas técnicas novas relacionadas a essas atividades, o que também ocorreu nas Empresas 1 e 2.

Como conseqüência das alterações nas atividades de custos, orçamento e análise de desempenho, a atividade de suporte de informações, na Empresa 1 foi intensificada e na Empresa 2 foi introduzida, visto que nessa última empresa, antes da implementação do R/3, os funcionários não eram comprometidos com tais atividades e não solicitavam suporte de informação para a área de Contabilidade.

Quanto à necessidade de utilização do programa Excel, foi constatado que o R/3 apresenta uma deficiência referente à disponibilização de relatórios, visto que os relatórios padronizados não atendem à necessidade dos usuários, além de ser demasiadamente demorada a emissão dos mesmos. Para suprir essa deficiência, os dados do R/3 são extraídos e transferidos para o programa Excel, o qual permite a elaboração dos relatórios segundo a necessidade do usuário. Esse fato ocorre e está presente tanto na Empresa 1 quanto na Empresa 2. A pesquisa realizada por Riccio (2001) confirma a deficiência do R/3 quanto a relatórios e a necessidade de utilização de outro software para suprir tal deficiência. Os resultados das pesquisas de Carvalho Filho (2001) e dos autores estrangeiros (FAHY; LINCH, 1999; MACARRONE, 2001; GRANLUND; MALMI, 2000) evidenciam que houve maior facilidade quanto à elaboração de relatórios gerencias, todavia, não mencionam a necessidade de outros programas. 
As atividades específicas do contador, nas Empresas 1 e 2, não tiveram muitas alterações. Na Empresa 1 as atividades foram praticamente mantidas e na Empresa 2 houve descentralização das atividades de natureza operacional. Nessas empresas, os contadores estão envolvidos apenas com a Contabilidade Financeira. Quanto aos responsáveis pela Contabilidade Gerencial, que não são contadores, suas atividades envolvem a análise dos critérios de rateio, dos relatórios e a explicação destes aos interessados. Tais atividades estão próximas às de um consultor. As pesquisas de Riccio (2001) e Carvalho Filho (2001) confirmam essas alterações. Ao que parece, houve uma valorização das atividades dos envolvidos com a Contabilidade Gerencial, pois estão mais atuantes como apoio à gestão das empresas. Todavia, os contadores das Empresas 1 e 2 não fazem parte desse grupo.

Uma situação específica foi a incorporação do controle do módulo PP (que se refere à área de produção) na área de Assessoria de Custos, a qual tem como foco atividades relacionadas à Contabilidade Gerencial. Esse fato ocorreu devido à falta de qualificação dos funcionários da área de produção para realizar as atividades referentes a PP. Todavia, a Assessoria de Custos adotou uma postura diferente daquela adotada pela área de Contabilidade (financeira) e não promoveu treinamento necessário para capacitar as pessoas da área de produção, mas ao contrário, trouxe para si o controle do módulo PP. Tendo em vista que a pessoa responsável pela área de Assessoria de Custos fez parte da equipe de projeto do módulo PP, parece existir uma tendência à centralização, não como uma política da empresa, mas como uma postura individual do responsável pela Assessoria de Custos, o que é natural, porque este funcionário ajudou a “construir” o módulo PP e, portanto, conhece seus pormenores.

Além dessas alterações nas atividades promovidas pelo R/3, este sistema, em função da sua estrutura voltada a processos, exige que se conheça os processos da empresa com profundidade para realizar as atividades de forma mais adequada. Por conseqüência, promoveu a conscientização dos funcionários sobre o reflexo da atividade de cada um nas atividades dos demais, tanto na Empresa 1 quanto na Empresa 2. A Contabilidade, especificamente, pode obter vantagens quando os funcionários têm essa consciência, pois como a Contabilidade possui a característica de sistema consolidador, ou seja, todas as transações que ocorrem na empresa refletem na Contabilidade, os funcionários, de certa forma, estão mais atentos sobre seu papel nas atividades da Contabilidade e tanto as informações passam a ser mais confiáveis, quanto a Contabilidade passa a ser mais 
valorizada, pois agora as pessoas sabem como as informações contidas nos relatórios contábeis são construídas. Por outro lado, se essa consciência não estiver atrelada ao comprometimento, haverá problemas, como os identificados na Empresa 1 relacionados a erros nos registros contábeis e nesse caso não acontecerá a valorização da Contabilidade, pois ela permanece não tendo utilidade para aquele determinado grupo de usuários não comprometidos.

\subsubsection{Alterações relacionadas aos conhecimentos e habilidades}

Quanto aos conhecimentos e habilidades, estes são conseqüência das alterações nas atividades. Com a Contabilidade disseminada na empresa, é preciso conhecer mais profundamente sobre a técnica contábil (graduação em Ciências Contábeis) para desenvolver melhores análises e também para atender aos usuários, os quais têm opiniões e necessidades diversas e buscam informações com os funcionários da área de Contabilidade, que precisam estar em condições de atendê-los. Não basta mais conhecer detalhes apenas sobre suas atividades, é preciso ter uma visão geral sobre as práticas contábeis na empresa, ou, pelo menos, saber onde obter tais informações. Além disso, a maior intensidade de atividades que envolvem análise demandam senso crítico e capacidade de análise. Por fim, como os funcionários da área de Contabilidade estão em constante contato com os demais funcionários da empresa, seja para ministrar treinamentos, seja para atendê-los com suporte de informações, é necessário que possuam habilidades relacionadas à comunicação e relacionamento interpessoal.

Quanto ao conhecimento de inglês, os funcionários da área de Contabilidade da Empresa 1 acreditam ser necessário dominar esse idioma, tanto para obter suporte técnico quanto para trabalhar no dia-a-dia com o sistema. Já os funcionários da Empresa 2 não sentiram essa necessidade. Ao que parece, pelo menos até o momento da coleta de dados para esta pesquisa, o conhecimento desse idioma era, de fato, necessário, principalmente pela necessidade de solicitação de suporte técnico. Na Empresa 2, quando os funcionários da Contabilidade precisam de suporte técnico, primeiramente entram em contato com a área de informática da empresa, a qual, se não consegue resolver o problema, faz contato com o suporte técnico do $\mathrm{R} / 3$. Dessa forma, são as pessoas da área de informática que sentem a necessidade do inglês. Talvez essa seja uma exigência do R/3, e não dos ERPs em geral, pois a equipe de suporte 
técnico deste software está localizada em outro país.

Os detalhes sobre todas essas alterações podem ser obtidos na apresentação e análise individual de cada caso, nos itens 4.1 e 4.2 . 


\section{CONCLUSÕES}

Este estudo foi conduzido com o propósito de compreender a influência do ERP na área de Contabilidade das empresas, quanto aos aspectos organizacionais relacionados à estrutura organizacional, atividades e conhecimentos e habilidades. Para tanto, foi utilizada a metodologia estudo de casos múltiplos, sendo analisados dois casos referentes a empresas que implementaram o ERP R/3 do fornecedor SAP. Posteriormente, foi procedida uma análise comparativa desses dois casos, inclusive relacionando-os com os resultados de algumas pesquisas já publicadas, as quais, embora não tenham o mesmo objetivo que este estudo, apresentam algumas evidências que contribuíram para a compreensão dos resultados desta pesquisa.

Em consonância com as constatações de Riccio (2001), a análise dos resultados indica que a implementação do ERP provoca, na área de Contabilidade das empresas, algumas alterações na estrutura organizacional, nas atividades e nos conhecimentos e habilidades necessários para a execução das atividades. Entretanto, a intensidade com que as mudanças ocorrem depende das decisões tomadas pelos responsáveis pela empresa e pela equipe de projeto, durante a fase de implementação do ERP e também, posteriormente, quando o sistema já está em produção.

As alterações verificadas nas empresas 1 e 2 foram detalhadamente descritas e analisadas no capítulo 4 e são, neste momento, resgatadas, como forma de apoiar o desenvolvimento das conclusões.

Quanto à estrutura organizacional, a análise dos resultados indica que quando acontecem mudanças nas atividades da área de Contabilidade, a estrutura organizacional sofre os reflexos dessas alterações, tanto no desenho, quanto na estrutura de cargos e no quadro de funcionários.

Essa conclusão baseia-se no fato de que, na Empresa 2, a qual promoveu a revisão ampla da estrutura organizacional, ocorreram as seguintes alterações: reorganização dos setores (desenho organizacional); criação de uma área para centralizar as atividades relacionadas ao módulo CO (desenho organizacional); reestruturação dos cargos; e redução da quantidade de 
pessoas na área de Contabilidade. Já na Empresa 1, que não promoveu a revisão ampla da estrutura organizacional, mas que também realizou algumas mudanças nas atividades, as alterações foram: criação de uma área para centralizar as atividades relacionadas ao módulo CO e mudanças na estrutura dos cargos, embora ainda não estivessem formalmente implementadas. Na Empresa 1, não houve mudanças na quantidade de pessoas da Contabilidade.

Depreende-se, da análise dos dados, que, dependendo da intensidade das alterações nas atividades, a estrutura organizacional sofre alterações de maior ou menor profundidade. Algumas relações podem ser estabelecidas:

- Quando as atividades são alteradas, independente de a empresa promover ou não a revisão ampla da estrutura organizacional, algumas mudanças no desenho organizacional da área de Contabilidade acontecem, mesmo que informalmente, relacionadas à forma de agrupar as atividades nos setores e à criação de novos setores para atender as exigências do ERP.

- Quando mudam as atividades, ocorrem alterações na forma de agrupá-las nos cargos, o que provoca mudança na denominação destes e os tornam mais valorizados.

- Quanto maior a descentralização dos registros contábeis, aliada à maior facilidade e agilidade na execução das atividades que permanecem na Contabilidade, ocorre uma demanda por um número menor de pessoas nesta área, provocando a redução de pessoal.

Com relação às mudanças nas atividades, a análise dos resultados indica que a estrutura do ERP tem potencial para alterar tais atividades. Todavia, as alterações variam de empresa para empresa, pois a implementação do ERP, por si, não promove sempre as mesmas mudanças; estas dependem das diversas decisões tomadas pelos gestores e pela equipe de projeto.

As alterações referentes às atividades da Contabilidade Financeira e da Contabilidade Gerencial subsidiaram a conclusão exposta no parágrafo anterior. Quanto às mudanças na Contabilidade Financeira, verificadas nas empresas 1 e 2, dizem respeito à: descentralização dos registros contábeis; execução de forma mais fácil e ágil das atividades que permanecem na área; introdução das atividades de suporte de informação e de treinamento aos demais funcionários; e intensificação de atividades de análise. Podem-se elaborar alguns 
relacionamentos:

- A estrutura do ERP tem potencial para promover tais alterações citadas, tendo em vista que este sistema estabelece que a inserção dos dados contábeis não seja procedida na área de Contabilidade, mas nas diversas áreas da empresa, e também porque utiliza um único banco de dados, facilitando e agilizando a execução das atividades que permanecem na área de Contabilidade, já que todos os dados necessários estão disponíveis.

- Se a inserção dos dados no sistema, realizada pelas diversas áreas da empresa, não for executada de forma adequada, a Contabilidade pode adotar uma postura mais conservadora, como ocorreu com a Empresa 1, e manter para si a execução de todos os registros possíveis, intensificando a atividade de conferência para garantir a confiabilidade dos dados que são inseridos em outras áreas. Pode também adotar uma postura mais arrojada, como a da Empresa 2 e, de fato, descentralizar os registros, mantendo para si apenas aqueles necessários ao fechamento do período e optar por outra alternativa para solucionar a falta de confiabilidade dos dados.

- Quanto maior a descentralização dos registros contábeis, mais intensas são as atividades de análise e de suporte de informações aos demais setores da empresa. Também há maior necessidade de que os funcionários dos diversos setores da empresa tenham conhecimento sobre Contabilidade, o que pode ser obtido através de treinamento ministrado pelos próprios funcionários da Contabilidade.

Quanto às mudanças na Contabilidade Gerencial, verificadas nas empresas 1 e 2, dizem respeito à: elaboração mais criteriosa dos custos; possibilidade de desenvolver análises gerenciais mais sofisticadas e detalhadas sobre custos; maior facilidade e agilidade na execução das atividades relacionadas a orçamentos e análise de desempenho; maior solicitação dos funcionários da empresa por suporte de informações; e necessidade de utilização de outro software para a elaboração de relatórios. Alguns relacionamentos podem ser definidos:

- O ERP disponibiliza ferramentas para utilização de técnicas mais sofisticadas relacionadas a custos e análise de desempenho, como por exemplo o custeio ABC e o Balanced Scorecard. Todavia, tais inovações não foram implementadas nas empresas 
1 e 2, possivelmente porque as empresas ainda estavam passando por uma fase de adaptação às funcionalidades básicas do sistema. Talvez numa segunda fase as empresas, tendo superado as dificuldades iniciais, tenham condições de evoluir e implementar essas novas técnicas.

- Os recursos tecnológicos disponibilizados pelo ERP, relacionados às atividades de orçamento e análise de desempenho, não garantem êxito na execução de tais atividades. É necessário aliá-los a políticas que promovam o comprometimento dos funcionários com essas ferramentas.

- A atividade de elaboração de relatórios gerenciais demanda a utilização de outro software, geralmente o Excel, devido a uma deficiência do R/3. Talvez os sistemas de outros fornecedores não tenham a mesma deficiência. Portanto, não pode ser atribuído ao ERP essa alteração na atividade e sim, especificamente, ao software R/3.

- Algumas atividades podem ser valorizadas, como o controle do imobilizado, orçamento e análise de desempenho. Todavia, essa valorização pode não ser diretamente provocada pela implementação do ERP. As atividades que, por qualquer motivo, não eram realizadas de forma adequada e, com o R/3, são executadas com maior facilidade, só serão valorizadas se forem percebidas como úteis, ou seja, o R/3 disponibiliza a tecnologia, mas não garante a valorização.

Com relação às mudanças nos conhecimentos e habilidades necessários à execução das atividades da área de Contabilidade, a análise dos resultados indica que a implementação do ERP demanda novos conhecimentos e habilidades. Entretanto, da mesma forma que a estrutura organizacional, a intensidade das alterações parece estar relacionada à profundidade das mudanças ocorridas nas atividades.

As novas exigências percebidas nas empresas 1 e 2 referem-se à necessidade de conhecer mais profundamente a técnica contábil, conhecer os processos da empresa, possuir senso crítico, possuir capacidade de análise, estar apto a manter bom relacionamento interpessoal e estar apto a desenvolver boa comunicação. É possível estabelecer alguns relacionamentos:

- O ERP promove a disseminação da Contabilidade pela empresa e os funcionários passam a utilizar a Contabilidade em seu dia-a-dia. Todavia, o conhecimento dessas pessoas sobre as práticas da Contabilidade é limitado e os funcionários da área de 
Contabilidade devem estar preparados para dirimir essas dúvidas. Para tanto, precisam conhecer mais profundamente a Contabilidade. Além disso, essas alterações também exigem que os funcionários da Contabilidade estejam constantemente em contato com outras pessoas, o que demanda maior habilidade em relacionamento interpessoal e em comunicação. Portanto, quanto mais disseminada estiver a Contabilidade, maior será a necessidade por conhecimento mais aprofundado sobre as técnicas da Contabilidade, por habilidade em relacionamento interpessoal e comunicação.

- As atividades de análise já eram realizadas na Contabilidade, mas em virtude da redução de algumas atividades e da maior facilidade e agilidade em executar outras, foi disponibilizado mais tempo para que as análises fossem feitas tanto no sentido de acompanhar a realização das atividades que foram descentralizadas como no sentido de melhorar a qualidade das informações geradas na área de Contabilidade.

- Se os demais funcionários da empresa conhecerem melhor os processos da mesma e perceberem o reflexo de suas atividades nas atividades realizadas na Contabilidade, os dados inseridos serão mais confiáveis e a informação produzida será de melhor qualidade. Além disso, por conhecerem como a informação é gerada, esta passa a ser mais útil e, por conseqüência, a Contabilidade tende a ser mais valorizada.

- Quanto aos funcionários da Contabilidade, é preciso que também conheçam os processos da empresa para ter condições de orientar os demais funcionários em suas dificuldades e para preparar informações de melhor qualidade.

Além das conclusões já comentadas, a análise dos resultados conduz a algumas considerações complementares.

Percebe-se que a implementação de um ERP influencia mais intensamente as atividades e, como conseqüência, a estrutura organizacional e os conhecimentos e habilidades sofrem reflexos e precisam ser ajustados. Essa evidência confirma o entendimento de Galliers (1998) de que a alteração em um dos elementos da organização provoca impactos nos demais, pois os elementos estão interligados, interagem a fim de alcançar determinado objetivo.

Quanto à forma como a empresa vai ajustar os elementos do desenho organizacional e da estrutura de cargos às mudanças nas atividades, algumas alternativas podem ser elaboradas e cada empresa vai organizar sua estrutura organizacional de acordo com diversos fatores, como por exemplo a disponibilidade de pessoas com conhecimento contábil e a cultura da empresa. 
Tal postura está em consonância com as teorias contingenciais. (ROBBINS, 1990).

Outro fator a ser observado é a influência dos Fatores Críticos de Sucesso referentes à implementação do ERP nas alterações verificadas, tanto nas atividades quanto na estrutura organizacional. A relevância desse entendimento repousa no fato de que muitas das alterações na área de Contabilidade podem estar relacionadas a esses fatores críticos. Os resultados da pesquisa indicam que quando estes não são atendidos, podem ocorrer falhas e, para corrigilas, algumas alterações nas atividades e na estrutura organizacional devem ser promovidas. Dessa forma, tais alterações não são provocadas pelo potencial do ERP, mas por problemas na implementação deste, tendo em vista a não observância dos fatores críticos de sucesso.

Por fim, a análise dos resultados indica que, em alguns casos, embora as atividades referentes à Contabilidade Gerencial estejam sendo executadas, pode acontecer de os funcionários não as relacionarem à Contabilidade, entendendo que são atividades de apoio à gestão e que a Contabilidade tem apenas o papel de fornecer os dados financeiros. Isso foi verificado na Empresa 1, na qual a área responsável pela Contabilidade Gerencial é denominada Controladoria, mas o entendimento que os funcionários têm da mesma é que ela é equivalente a planejamento, não tendo relação alguma com a Contabilidade. Nesse contexto a Contabilidade é vista sob a abordagem restrita e sem a responsabilidade de fornecer informações gerenciais.

Por um lado, a análise dos dados conduz ao entendimento de que, com a disseminação da Contabilidade na empresa, há uma tendência em valorizá-la, uma vez que é compreendida e percebida como útil. Por outro lado, essa utilidade fica restrita se a percepção das pessoas sobre Contabilidade estiver focada apenas na Contabilidade Financeira. Verificar a percepção do usuário sobre a abrangência e a utilidade da Contabilidade após a implementação do ERP não fez parte do objetivo desta pesquisa, todavia, novas pesquisas podem ser desenvolvidas de forma a obter essa compreensão. 


\section{REFERÊNCIAS}

ATKINSON, Anthony A. et al. Contabilidade gerencial. São Paulo: Atlas, 2000.

BABBIE, Earl R. The practice of social research. 9th ed. Belmont: Wadsworth-Thomson Learning, 2001.

BAGRANOFF, Nancy A. et al. Who moved my ledger? The CPA Journal. New York, v 72, p. 22-26, 10/2002. Proquest ABI/Inform (R Global 04-12/2002).

BANCROFT, Nancy H. et al. A implementing SAP R/3: how to introduce a large system into a large organization. Greenwich: Manning Publications, 1998.

BERGAMASCHI, Sidnei. Um estudo sobre projetos de implementação de sistemas para gestão empresarial. São Paulo, 1999. Dissertação (Mestrado em Administração) - Programa de Pós-Graduação em Administração, Departamento de Administração, Faculdade de Economia, Administração e Contabilidade da Universidade de São Paulo.

BERMUDEZ, John. Enterprise commerce management: a new era in enterprise systems. AMR Research - ALERT. MA, 02/04/2001. Disponível em: $<$ http://www.amrresearch.com>. Acesso em: 02/04/2001.

BLAIN, J. et al. Administering SAP R/3: the FI-financial accounting and CO-controlling modules. US: QUE Corporation, 1998.

BRYMAN, Alan. Research methods and organization studies. New York: Routledge, 1995.

CALDAS, Miguel P.; WOOD JR., Thomas. Fads and fashions in management: the case of ERP. Revista de Administração de Empresas. São Paulo, n. 3, v.40, p. 8-17, 07-09/2000.

CARDOSO, Douglas. Avaliação do SAP R/3 como instrumento para a gestão financeira: um estudo de caso no setor siderúrgico brasileiro. Belo Horizonte, 2001. Dissertação (Mestrado em Administração) - Centro de Pós-Graduação e Pesquisas em Administração, Universidade Federal de Minas Gerais.

CARVALHO FILHO, Antonio Francisco de. O impacto da implantação dos softwares de ERP - Enterprise Resource Planning - na contabilidade gerencial e no papel do contador gerencial. São Paulo, 2001. Dissertação (Mestrado em Finanças) - Escola de Administração de Empresas de São Paulo, Fundação Getúlio Vargas.

CHANDLER JR., Alfred D. Strategy and structure: chapters in the history of the industrial enterprise. Massachusetts: MIT Press, 1962. 
CHIAVENATO, Idalberto. Administração nos novos tempos. São Paulo: Makron Books, 1999.

CHIAVENATO, Idalberto. Gestão de pessoas: o novo papel dos recursos humanos nas organizações. Rio de Janeiro: Campus, 1999.

CHURCHMAN, C. West. Introdução à teoria dos sistemas. 2. ed. Rio de Janeiro: Vozes, 1972.

DAVENPORT, Thomas H. Putting the enterprise into the enterprise system. Harvard Business Review. MA: HBSP, p. 121-131, 07-08/1998.

DEMO, Pedro. Metodologia científica em ciências sociais. 3. ed. São Paulo: Atlas, 1995.

DENZIN, Norman K.; LINCOLN, Yvonna S. Handbook of qualitative research. London: SAGE Publication Inc., 1994.

FUNDAÇÃO GETÚLIO VARGAS. Escola de Administração de Empresas de São Paulo. Centro de Informática Aplicada. Pesquisa anual administração de recursos de informática. São Paulo. 16. ed., 2005. Disponível em: http://www.fgvsp.br/cia/pesquisa. Acesso em 20/06/2005.

FUNDAÇÃO INSTITUTO DE PESQUISAS CONTÁBEIS, ATUARIAIS E FINANCEIRAS - FIPECAFI. Manual de contabilidade das sociedades por ações. 4. ed. São Paulo: Atlas, 1995.

GALLIERS, Bob. Reflections on BPR, IT and organizational change. In: GALLIERS, Bob; W.R.J. Baets. Information Technology and organizational transformation. [S.l.]: John Wiley \& Sons, 1998.

GIBSON, James L. et al. Organizações: comportamento, estrutura, processos. São Paulo: Atlas, 1981.

GRAEML, Alexandre Reis. Sistemas de informação: o alinhamento da estratégia de TI com a estratégia corporativa. São Paulo: Atlas, 2000.

GRANLUND, Markus; MALMI, Teemu. Moderate impactos of ERPS on management accounting: a lag or permanent outcome? Management Accounting Research. [S.l.], v. 13, p. 299-321, 2002. Disponível em <http://www.idealibrary.com.on > Acesso em: 10/01/2003.

HABERKORN, Ernesto. Teoria do ERP: enterprise resource planning. 2. ed. São Paulo: Makron Books, 1999. 
Contabilidade inside ERP. São Paulo: Makron Books, 2001.

HALL, James A. Accounting information systems. 3rd ed. Cincinnati-Ohio: South-Western College Publishing, 2001.

HALL, Richard H. Organizações: estruturas, processos e resultados. 8. ed. São Paulo: Prentice Hall, 2004.

HAMMER, Michael. A voz do dono. SAPerspectiva. São Paulo, n.10, p. 24-25, 06/99. Disponível em: <http://www.sap.com.br> Acesso em: 05/06/2003.

HAMILTON, Scott. Justification of ERP investments: part one: quantifiable benefits from an ERP system. Technology Evaluation, [S.l.], p. 1-8, 10/02/2004a. Disponível em: <http:// www.technologyevaluation.com> Acesso em: 12/02/2004.

HAMILTON, Scott. Justification of ERP investments: part two: the intangible effects of ERP. Technology Evaluation, [S.l.], p. 1-5, 10/02/2004b. Disponível em: <http:// www.technologyevaluation.com> Acesso em: 12/02/2004.

HEDMAN, Jonas; BORELL, Andreas. The impact of enterprise resource planning systems on organizational effectiveness: an artifact evaluation. In: FUI, Fionna; NAH, Hoon. Enterprise resource planning solutions \& management. [S.l.]: IRM Press, 2002.

HEHN, Herman F. O papel dos recursos humanos nas implementações de TI. SAPerspectiva. São Paulo, n. 12, p. 64-65, 12/99. Disponível em: <http://www.sap.com.br> Acesso em: 05/06/2003.

HERRIOT, R.E.; FIRESTONE, W.A. Multisite qualitative policy research: optimizing description and generalizability. Educational Researcher, 12, 1983 apud YIN, Robert K. Estudo de caso: planejamento e métodos. 2. ed. Porto Alegre: Bookman, 2001.

INTERNATIONAL FEDERATION OF ACCOUNTANTS - IFAC. Proposed international education guideline. New York, 1996.

KALE, Vivek. Implementing SAP R/3. Indianopolis: SAMS, 2000.

KUMAR, Vinod et al. An investigation of critical management issues in ERP implementation: empirical evidence from Canadian organizations. Technovation, 2001. Disponível em: <http//www.elsevier.com/locate/technovation> Acesso em: 27/02/2002.

LECOMPTE, M.D. et al. Etnography and qualitative design in educational research. 2nd ed. New York: Academic Press, 1993 apud DENZIN, Norman K.; LINCOLN, Yvonna S. Handbook of qualitative research. London: SAGE Publication Inc., 1994. 
MINTZBERG, Henry. Criando organizações eficazes: estruturas em cinco configurações. São Paulo: Atlas, 2003.

MORSE, Janice M. Designing funded qualitative research. In: DENZIN, Norman K.; LINCOLN, Yvonna. Handbook of qualitative research. London: SAGE Publication Inc., 1994.

MOSCOVE, Stephen A. et al. Sistemas de informações contábeis. São Paulo: Atlas, 2002.

NADLER, David A. et al. Arquitetura organizacional: a chave para a mudança empresarial. Rio de Janeiro: Campus, 1994.

OLIVARES, José E. Louffat. Uma contribuição ao estudo da interação da estrutura organizacional com a estrutura de carreiras nas organizações: o caso do Instituto de Pesquisas Energéticas e Nucleares (IPEN). São Paulo, 1999. Dissertação (Mestrado em Administração) - Programa de Pós-Graduação em Administração, Departamento de Administração, Faculdade de Economia, Administração e Contabilidade da Universidade de São Paulo.

PONTES, Benedito Rodrigues. Administração de cargos e salários. 8. ed. São Paulo: LTR, 2000.

REILLY, Kevin. AMR Research releases ERP market report showing overall market growth of 14\% in 2004. AMR Research. MA, 14/06/2005. Disponível em: <http://www.amrresearch.com> Acesso em: 20 jun. 2005.

RICCIO, Edson Luiz. Uma contribuição ao estudo da contabilidade como sistema de informação. São Paulo, 1989. Tese (Doutorado em Administração) - Programa de PósGraduação em Administração, Departamento de Administração, Faculdade de Economia, Administração e Contabilidade da Universidade de São Paulo.

- Efeitos da tecnologia de informação na contabilidade: estudo de casos de implementação de sistemas empresariais integrados - ERP. São Paulo, 2001. Tese (Livredocência) - Departamento de Contabilidade e Atuária, Faculdade de Economia, Administração e Contabilidade da Universidade de São Paulo.

ROBBINS, Stephen P. O processo administrativo: integrando teoria e prática. São Paulo: Atlas, 1978.

Organization theory: structure, design, and applications. 3rd ed. New Jersey: Prentice-Hall, 1990.

SCAPENS, R. SAP: Integrated information systems and the implications for management accountants. Management Accounting. London, v. 76, p. 46-48, 09/1998. Proquest ABI/Inform (R Global 24-07/2003). 
SCOTT, Fenella; SHEPHERD, Jim. The steady stream of ERP investments. AMR Research - ALERT. MA, 26/08/2002. Disponível em: <http://www.amrresearch.com> Acesso em: 03/07/2003.

STIJN, Eveline van. Beyond ERP systems as a hype: understanding ERP systems as distinct technological, organizational and cognitive phenomena. In: FUI, Fionna; NAH, Hoon. Enterprise resource planning solutions \& management. [S.l.]: IRM Press, 2002.

SOUZA, Cesar Alexandre de. Sistemas integrados de gestão empresarial: estudos de casos de implementação de sistemas. São Paulo, 2000. Dissertação (Mestrado em Administração) Programa de Pós-Graduação em Administração, Departamento de Administração, Faculdade de Economia, Administração e Contabilidade da Universidade de São Paulo.

SOUZA, César Alexandre, ZWICKER, Ronaldo. Sistemas ERP: conceituação, ciclo de vida e estudos de casos comparados. In: SOUZA, César Alexandre; SACCOL, Amarolinda Zanela (Org.). Sistemas ERP no Brasil: (enterprise resource planning) teoria e casos. São Paulo: Atlas, 2003.

TACHIZAWA, Takeshy; SCAICO, Oswaldo. Organização flexível: qualidade na gestão por processos. São Paulo: Atlas, 1997.

TURBAN, Efraim et al. Administração de tecnologia da informação. Rio de Janeiro: Campus, 2003.

TURNER, Jon A. The role of information technology in organizational transformation. In GALLIERS, R.D; W.R.J. Baets. Information technology and organizational transformation. [S.l.]: John Wiley \& Sons, 1998.

TYLER, Geoff. ERP redefines itself. Management Services. Enfield, v. 46, p. 24-28, 10/2002. Proquest ABI/Inform (R Global 04-12/2002).

WALTON, Richard E. Tecnologia de informação: o uso de TI pelas empresas que obtêm vantagem competitiva. São Paulo: Atlas, 1993.

WILKINSON, Joseph W. et al. Accounting information systems: essential concepts and applications. 4th Ed. New York: John Wiley, 2000.

WINFIELD, Ian. Organization and information technology: a practical review. Oxford: Blackwell Scientific Publications, 1991.

WU, Frederick H. Accounting information systems: theory and practice. New York: McGraw-Hill, 1983. 
VASCONCELLOS, Eduardo; HEMSLEY, James R. Estrutura das organizações: estruturas tradicionais, estruturas para inovação, estrutura matricial. 4. ed. São Paulo: Pioneira Thomson Learning, 2002.

YIN, Robert K. Estudo de Caso: planejamento e métodos. 2.ed. Porto Alegre: Bookman, 2001.

ZIMPECK, Beverly Glen. Administração de salários: sistemas e métodos de análise e descrição de cargos, pesquisa e escalas salariais, avaliação de desempenho, avaliação de cargos. 7. ed. São Paulo: Atlas, 1992. 


\section{APÊNDICES}

APÊNDICE 1: ROTEIRO PARA ENTREVISTA COM O RESPONSÁVEL PELA ÁREA DE CONTABILIDADE

APÊNDICE 2: ROTEIRO PARA ENTREVISTA COM OS FUNCIONÁRIOS DA ÁREA DE CONTABILIDADE

APÊNDICE 3: ROTEIRO PARA ENTREVISTA COM O RESPONSÁVEL PELA ÁREA DE RECURSOS HUMANOS

APÊNDICE 4: ROTEIRO PARA ENTREVISTA COM O RESPONSÁVEL PELA ÁREA DE INFORMÁTICA

APÊNDICE 5: DESCRIÇÕES DE CARGOS DO CASO 1 APÊNDICE 6: DESCRIÇÕES DE CARGOS DO CASO 2 


\section{APÊNDICE 1}

\section{ROTEIRO PARA ENTREVISTA COM O RESPONSÁVEL PELA ÁREA DE CONTABILIDADE}

Data da entrevista: início: término:

\section{DADOS DA EMPRESA}

1.1 Nome:

1.2 Ramo de atuação:

1.3 Faturamento anual:

1.4 Quantidade de empregados:

1.5 Ano de início das atividades:

\section{DADOS DO ENTREVISTADO}

2.1 Nome:

2.2 Área:

2.3 Cargo:

2.4 Formação:

Nível de escolaridade:

2.5 Tempo na empresa:

Tempo no cargo:

\section{IMPLEMENTAÇÃO}

3.1 Quais fatores foram os motivadores da implementação do sistema R/3?

3.2 Quais softwares eram utilizados anteriormente pela área de Contabilidade? Qual era o nível de integração com outros sistemas da empresa?

3.3 Atualmente, a Contabilidade utiliza outros sistemas para suprir informações não oferecidas pelo R/3? Quais? Estão integrados ao R/3 ou utilizam outra base de dados?

3.4 Qual seu papel na implementação do sistema? 


\section{ESTRUTURA ORGANIZACIONAL}

4.1 Ocorreram mudanças na estrutura organizacional da área de Contabilidade após a implementação do R/3? Se houve alterações, elas se relacionam:

( ) a níveis hierárquicos;

( ) ao tipo de estrutura;

( ) à autoridade para a tomada de decisões;

( ) à responsabilidade pelas atividades;

( ) à subordinação das áreas;

( ) à divisão das atividades;

( ) à forma de agrupar as atividades;

( ) a linhas de comunicação;

( ) a outros. Quais?

Por que ocorreram estas alterações?

4.2 Houve alteração dos processos internos da área de Contabilidade? Quando estas alterações ocorreram? Quais foram os principais fatores que motivaram a revisão dos processos? Quais pessoas foram responsáveis pela revisão dos processos?

4.3 Caso tenha havido mudanças nos processos internos da área de Contabilidade, quais foram as alterações?

4.4 Quantos funcionários trabalhavam na área de Contabilidade antes da implementação do $\mathrm{R} / 3$ ? Quantos são atualmente? Se houve alterações, por que elas ocorreram?

4.5 Houve substituição de funcionários na Contabilidade? Em caso afirmativo, por quê?

4.6 Os funcionários que não estão mais na área de Contabilidade ainda permanecem na empresa? Para quais áreas e cargos foram realocados? Por que os funcionários foram realocados?

4.7 Quais eram os cargos da área de Contabilidade antes da implementação do R/3 e quantas pessoas ocupavam cada cargo? Como está atualmente? Se houve alterações, por que elas ocorreram?

4.8 No caso de alterações nos cargos da área de Contabilidade, de quem foi a responsabilidade pela definição dos novos cargos? Houve a participação dos funcionários da área?

4.9 No caso de não ter havido alteração na estrutura organizacional da Contabilidade após a implementação do R/3, você considera que algumas alterações deveriam ter acontecido? Quais? Por quê?

4.10 Houve mudanças físicas no local onde a Contabilidade está instalada após a 
implementação do sistema? Se houve alterações, por que elas ocorreram?

\section{ANÁLISE DE CARGOS}

5.1 Quais são as atividades que você desenvolve atualmente?

5.2 Houve alterações nas atividades atribuídas ao seu cargo, ou na forma de desenvolvê-las após a implementação do R/3? Quais? Se houve alterações, por que elas ocorreram?

5.3 Qual nível de instrução você considera como mínimo necessário para ocupar esse cargo? Há necessidade de algum tipo de especialização? Especifique.

5.4 Houve alterações no nível de instrução necessário para ocupar esse cargo após a implementação do R/3? Quais? Se houve alterações, por que elas ocorreram?

5.5 Quais os conhecimentos exigidos do ocupante desse cargo para realizar as atividades previstas?

5.6 Houve alterações nos conhecimentos exigidos do ocupante desse cargo após a implementação do R/3? Quais? Se houve alterações, por que elas ocorreram?

5.7 Quais as habilidades exigidas do ocupante desse cargo para realizar as atividades previstas?

5.8 Houve alterações nas habilidades exigidas do ocupante desse cargo após a implementação do R/3? Quais? Se houve alterações, por que elas ocorreram?

5.9 Quais são os contatos (áreas, cargos das pessoas) mantidos internamente, necessários ao desempenho das atividades desse cargo? E os contatos mantidos externamente? Houve alterações após a implementação do R/3? Se houve alterações, por que elas ocorreram?

$5.10 \mathrm{Na}$ sua percepção, quais foram as principais alterações que ocorreram com relação às atividades e aos conhecimentos e habilidades necessários ao desenvolvimento das mesmas na área de Contabilidade após a implementação do R/3? Se houve alterações, por que elas ocorreram?

5.11 Em sua opinião, qual deve ser o perfil das pessoas que trabalham na área de Contabilidade (gerente e funcionários) de uma empresa que utiliza um ERP?

5.12 Em sua opinião, quais os principais benefícios que o R/3 proporciona para a Contabilidade? E os principais problemas provocados por ele?

5.13 Você tem algum comentário adicional a fazer sobre os efeitos do R/3 na estrutura da Contabilidade, atividades da área e conhecimentos e habilidades dos seus funcionários? 


\section{APÊNDICE 2}

\section{ROTEIRO PARA ENTREVISTA COM OS FUNCIONÁRIOS DA ÁREA DE CONTABILIDADE}

Data da entrevista: início: término:

\section{DADOS DO ENTREVISTADO}

\subsection{Nome:}

1.2 Cargo:

1.3 Formação:

Nível de escolaridade:

1.4 Tempo na empresa:

Tempo no cargo:

\section{DESCRIÇÃO DAS ATIVIDADES DO CARGO}

2.1 Quais são as atividades diárias (aquelas que se repetem com regularidade) que você desenvolve atualmente?

2.2 Quais são as atividades periódicas e sua freqüência (mensal, semanal, anual) desenvolvidas por você atualmente?

2.3 Esse cargo, ou equivalente a este, já existia antes da implementação do R/3? Houve alterações nas atividades referentes a ele ou na forma de desenvolver as atividades? Quais? Se houve alterações, por que elas ocorreram?

2.4 Qual cargo você ocupava antes da implementação do R/3? Esse cargo ainda existe? Houve alterações nas atividades referentes a ele ou na forma de desenvolver as atividades? Quais? Se houve alterações, por que elas ocorreram?

\section{ESPECIFICAÇÃO DOS REQUISITOS DO CARGO}

3.1 Qual o nível de instrução que você considera como mínimo necessário para ocupar esse cargo? Há necessidade de algum tipo de especialização? Especifique.

3.2 Qual era o nível de instrução necessário para ocupar esse cargo, ou equivalente a ele, 
antes da implementação do R/3? Se houve alterações, por que elas ocorreram?

3.3 Quais os conhecimentos exigidos do ocupante do cargo para realizar as atividades previstas?

3.4 Quais eram os conhecimentos exigidos do ocupante desse cargo, ou equivalente a ele, antes da implementação do R/3? Se houve alterações, por que elas ocorreram?

3.5 Quais as habilidades exigidas do ocupante do cargo para realizar as atividades previstas?

3.6 Quais eram as habilidades exigidas do ocupante desse cargo, ou equivalente a ele, antes da implementação do R/3? Se houve alterações, por que elas ocorreram?

3.7 Quais são os contatos (áreas, cargos das pessoas) mantidos internamente, necessários ao desempenho das atividades desse cargo? E os contatos mantidos externamente? Houve alterações após a implementação do R/3? Se houve alterações, por que elas ocorreram?

3.8 Você tem alguma informação adicional sobre os efeitos do R/3 nas atividades, conhecimentos e habilidades previstas para esse cargo? 


\section{APÊNDICE 3}

\section{ROTEIRO PARA ENTREVISTA COM O RESPONSÁVEL PELA ÁREA DE RECURSOS HUMANOS}

Data da entrevista: início: término:

\section{DADOS DO ENTREVISTADO}

\subsection{Nome:}

1.2 Área:

\subsection{Cargo:}

1.4 Formação:

Nível de escolaridade:

1.5 Tempo na empresa:

Tempo no cargo:

\section{ESTRUTURA ORGANIZACIONAL}

2.1 Existe a preocupação por parte da empresa em adequar sua estrutura organizacional às mudanças que ocorrem no seu ambiente interno ou externo?

2.2 Ocorreram mudanças na estrutura organizacional da empresa após a implementação do $\mathrm{R} / 3$ ? Se houve alterações, elas se relacionam:

( ) a níveis hierárquicos;

( ) ao tipo de estrutura;

( ) à autoridade para a tomada de decisões;

( ) à responsabilidade pelas atividades;

( ) à subordinação das áreas;

( ) à divisão das atividades;

( ) à forma de agrupar as atividades;

( ) a linhas de comunicação;

( ) a outros. Quais?

Por que ocorreram estas alterações?

2.3 Ocorreram mudanças na estrutura organizacional da área de Contabilidade após a 
implementação do R/3? Se houve alterações, elas se relacionam a:

( ) a níveis hierárquicos;

( ) ao tipo de estrutura;

( ) à autoridade para a tomada de decisões;

( ) à responsabilidade pelas atividades;

( ) à subordinação das áreas;

( ) à divisão das atividades;

( ) à forma de agrupar as atividades;

( ) a linhas de comunicação;

( ) a outros. Quais?

Por que ocorreram estas alterações?

2.4 No caso de não ter havido alteração na estrutura organizacional da empresa e/ou da Contabilidade, após a implementação do R/3, você considera que algumas alterações deveriam ter acontecido? Quais? Por quê?

\section{ANÁLISE DE CARGOS}

3.1 Como é a política de cargos e salários da empresa?

3.2 Quem é o responsável por sugerir alterações na nomenclatura dos cargos e/ou atividades que compõem os cargos em cada área?

3.3 Houve uma preocupação da empresa com a revisão dos cargos após a implementação do $\mathrm{R} / 3$ ? Ocorreram alterações? Se houve alterações, por que elas ocorreram?

3.4 Houve alteração no perfil dos cargos da área de Contabilidade após a implementação do $\mathrm{R} / 3$ ? Se houve alterações, por que elas ocorreram?

3.5 Quais eram os cargos da área de Contabilidade antes da implementação do R/3 e quantas pessoas ocupavam cada cargo? Como está atualmente? Se houve alterações, por que elas ocorreram? 


\section{ROTEIRO PARA ENTREVISTA COM O RESPONSÁVEL PELA ÁREA DE INFORMÁTICA}

Data da entrevista: início: término:

\section{DADOS DO ENTREVISTADO}

1.1 Nome:

1.2 Área:

1.3 Cargo:

1.4 Formação:

Nível de escolaridade:

1.5 Tempo na empresa:

Tempo no cargo:

\section{IMPLEMENTAÇÃO}

2.1 Quais fatores foram os motivadores da implementação do sistema R/3?

2.2 Quais softwares eram utilizados anteriormente? Qual o nível de integração existente?

2.3 Quando foi o início e o término da implementação do sistema?

2.4 Quais módulos foram implementados e quando ocorreu cada implementação?

\begin{tabular}{|l|l|l|}
\hline Áreas & Módulos/data & Módulos do FI-CO/data \\
\hline \multirow{4}{*}{ FINANCIALS } & FI - financial accounting d: & FI-GL - general ledger d: \\
\cline { 2 - 3 } & CO - controlling d: & FI-AP - accounting payable d: \\
\cline { 2 - 3 } & EC - enterprise controlling d: & FI-AR - accounting receivable d: \\
\cline { 2 - 3 } & TR - treasury d: & SPL - special purpose ledgers d: \\
\cline { 2 - 3 } & AM - asset management d: & FI-LC - legal consolidation d: \\
\hline HUMAN RESOURCES & Personnel development d: & FI-IM - investment management d: \\
\cline { 2 - 3 } & Compensation management d: & Overhead cost controlling d: \\
\cline { 2 - 3 } & SAP HR d: & CO-ABC - activity-based costing d: \\
\cline { 2 - 3 } AND LOGISTICS & Payroll accounting d: & CO-PC - product costing controlling d: \\
\cline { 2 - 3 } & Employee self service d: & CO-PA - profitability analysis d: \\
\cline { 2 - 3 } & Global SAP HR solution d: & CO-CCA - cost center accounting d: \\
\hline & SD - sales and distribution d: & CO-IO - internal orders d: \\
\cline { 2 - 3 } & PP - production planning d: & CO-PCA - profit center accounting d: \\
\cline { 2 - 3 } & MM - materials management d: & CO-EIS - executive information system d: \\
\cline { 2 - 3 } & PM - plant maintenance d: & \\
\cline { 2 - 3 } & QM - quality management d: & \\
\hline
\end{tabular}


2.5 Quais funções do FI/CO estão sendo utilizadas? Existe intenção de futuramente utilizar outras funções do FI/CO?

2.6 No processo de customização, houve muitas alterações do sistema original ou procurouse manter o padrão oferecido pelo R/3? No caso de alterações, em quais módulos? O que motivou essas alterações?

2.7 A implementação do R/3 foi considerada bem sucedida? Quais parâmetros foram utilizados nesta avaliação?

2.8 A empresa utiliza outros sistemas para suprir informações não oferecidas pelo R/3? Quais? Estão integrados ao R/3 ou utilizam outra base de dados? 


\section{APÊNDICE 5}

\section{DESCRIÇÕES DE CARGOS DO CASO 1}

As descrições de cargos abaixo foram elaboradas tendo por base as informações fornecidas pelos funcionários da área de Contabilidade e as informações fornecidas pelo contador, já que a Empresa 1 não dispunha de descrições dos cargos para orientar a pesquisa.

Uma restrição percebida pela pesquisadora é que, pelo fato de os dados terem sido coletados por meio de entrevista, os ocupantes dos cargos tinham dificuldade em lembrar, no momento da entrevista, de todas as atividades que executavam no dia-a-dia, já que muitas delas são periódicas. O mesmo ocorreu com as habilidades e conhecimentos. Além disso, os entrevistados foram orientados a informar sobre os conhecimentos e habilidades que o cargo exigia, não os que eles possuíam, mas algumas vezes foi percebido pela pesquisadora certa dificuldade em fazer tal separação. Também houve certa dificuldade, por parte dos entrevistados, em encontrar termos adequados que refletissem a habilidade que queriam citar. Surgiram comentários como "Nossa, deu um branco agora, parece que eu não faço nada” e também "Não sei direito como expressar as necessidades para esse cargo.”

Todavia, a pesquisadora acredita que essas restrições não prejudicaram os resultados, visto que mesmo tendo tais dificuldades quando questionados sobre as mudanças, os entrevistados responderam prontamente.

A seguir, encontram-se as descrições dos cargos que estão agrupadas em cargos relacionados à Contabilidade Financeira e à Contabilidade Gerencial. Após cada descrição, são comentadas as alterações percebidas nos cargos (atividades, conhecimentos e habilidades), tendo em vista a implementação do R/3. 
1. Descrições dos cargos relacionados à Contabilidade Financeira

A área de Contabilidade Financeira conta com uma estrutura de sete cargos que são: contador, encarregado, assistente contábil, analista contábil, auxiliar de Contabilidade II, auxiliar de escritório e auxiliar administrativo.

O cargo auxiliar de Contabilidade II é bastante amplo e prevê atividades nos setores fiscal, escrita fiscal e Contabilidade de coligadas. Como tais atividades são bastante distintas e buscando uma melhor visualização das atividades desenvolvidas em cada setor, foram elaboradas descrições de cargos separadas (quadros 1.5, 1.6 e 1.7).

Quadro no 1.1 - Descrição do cargo Contador

\begin{tabular}{|l|}
\hline 1. Título do Cargo: Contador \\
\hline 2. Unidade: Contabilidade \\
\hline 3. Descrição das Atividades: \\
Coordenar as atividades do setor; dar suporte aos funcionários com relação às atividades \\
desenvolvidas por estes; atuar junto aos gerentes e outros funcionários apresentando as \\
informações contábeis. \\
\hline 4. Especificações \\
\hline 4.1. Instrução: \\
técnico ou graduação em Ciências Contábeis. \\
4.2. Conhecimentos: \\
Contabilidade; direito; legislação; processos de compra e venda; \\
correlacionados à Contabilidade; básico em informática. \\
4.3. Especialização: \\
importante especialização na área contábil. \\
4.4. Experiência: \\
essencial experiência na prática contábil. \\
4.5. Responsabilidade: \\
sobre tudo o que se faz na área de Contabilidade. \\
4.6. Habilidades intelectuais: \\
ser crítico; ser analítico. \\
4.7. Habilidades interpessoais: \\
capacidade de liderar; saber relacionar-se com todas as áreas da empresa. \\
4.8. Habilidades de comunicação: \\
ser comunicativo. \\
\end{tabular}

O contador teve dificuldade em fornecer informações sobre suas atividades: "Eu não sei nem especificar, às vezes parece que não faço nada e tudo.”

Quando questionado sobre as mudanças, disse acreditar que não houve muita diferença. “Como contador não, como gestor eu diria que ele melhorou um pouquinho à medida que ele está relacionado com os demais setores.” Explicou que agora ele tem maior contato com os 
demais setores e ficou mais fácil coordenar as atividades da Contabilidade porque os gestores das outras áreas perceberam a importância de executar corretamente suas atividades, pois elas têm reflexos na Contabilidade.

Disse, ainda, que é cobrado pela Diretoria, uma vez que deveria desempenhar um papel mais estratégico, mas o dia-a-dia exige que ele ainda se envolva muito com o operacional, dando suporte.

Quadro ${ }^{0} 1.2$ - Descrição do cargo Encarregado

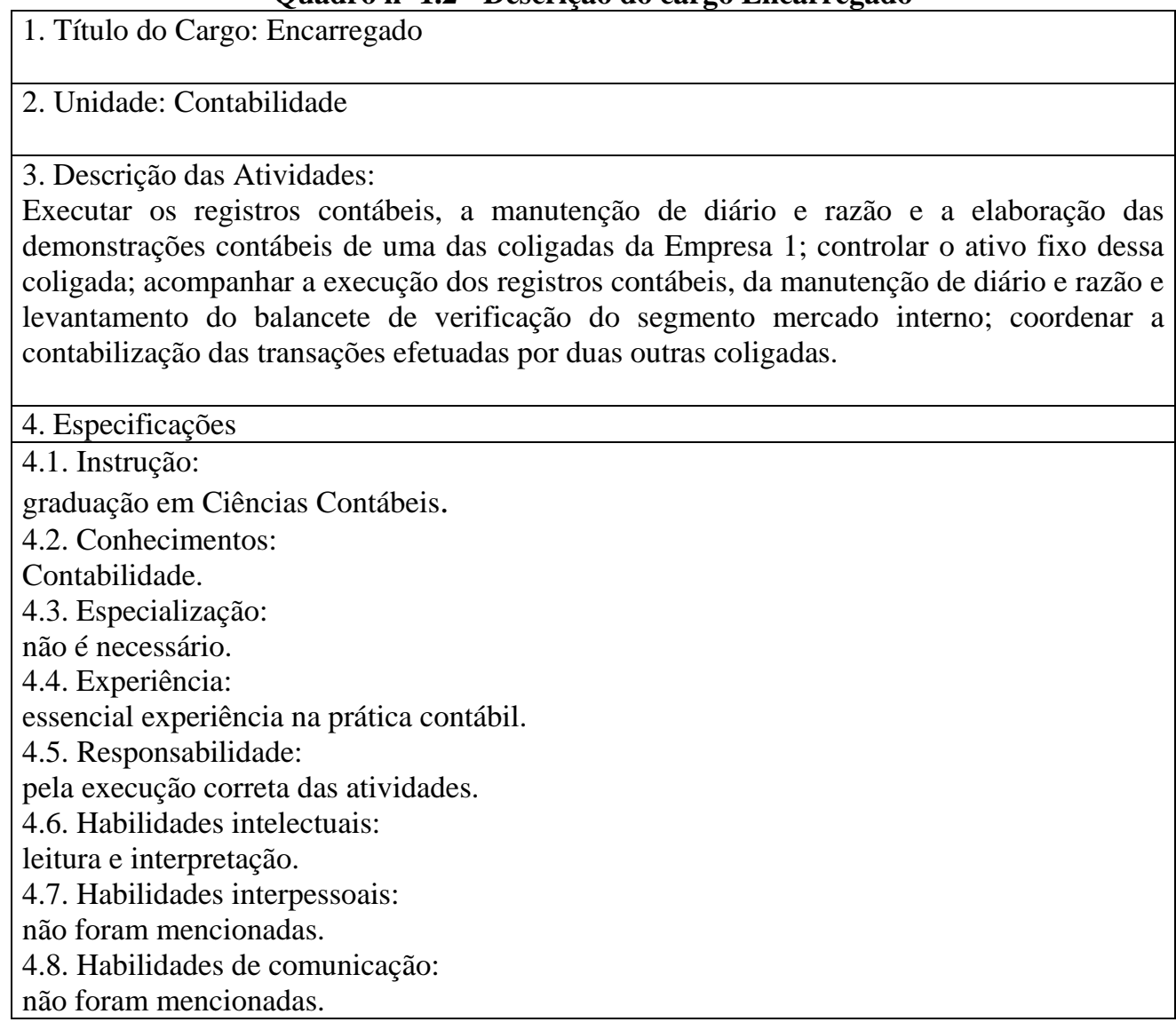

Na estrutura de cargos atual, esse cargo não existe. O funcionário que ocupa esse cargo está contratado como contador. Era o contador da empresa coligada que foi incorporada à Empresa 1. Com a incorporação, suas atribuições mudaram, mas não foi feita a alteração na nomenclatura do cargo. Segundo informações, essa situação será resolvida com a revisão da estrutura organizacional, que inclui a revisão dos cargos, que já foi iniciada.

Quando o R/3 foi implementado, essas atividades já existiam e, segundo informou o ocupante deste cargo, não houve alterações nas mesmas, nem nos conhecimentos e habilidades exigidos. 
Quadro no 1.3 - Descrição do cargo Assistente Contábil

\begin{tabular}{|l|}
\hline 1. Título do Cargo: Assistente Contábil \\
\hline 2. Unidade: Contabilidade \\
\hline 3. Descrição das Atividades: \\
Verificar se demonstrações estão de acordo com a legislação; verificar os procedimentos \\
em geral; verificar o recolhimento dos impostos; estar atualizado sobre as mudanças do \\
ambiente externo (legislação, fatos importantes para a empresa) e disseminar essas \\
informações; coordenar as atividades para atender a Receita Federal nas solicitações de \\
informações sobre fornecedores da Empresa 1. \\
\hline 4. Especificações \\
\hline $\begin{array}{l}\text { 4.1. Instrução: } \\
\text { graduação em Ciências Contábeis. } \\
\text { 4.2. Conhecimentos: } \\
\text { Contabilidade; informática; legislação. } \\
\text { 4.3. Especialização: } \\
\text { não é necessário. } \\
\text { 4.4. Experiência: } \\
\text { essencial prática na Contabilidade. } \\
\text { 4.5. Responsabilidade: } \\
\text { pela execução correta das atividades. } \\
\text { 4.6. Habilidades intelectuais: } \\
\text { buscar constante atualização dos conhecimentos; capacidade de análise crítica; visão } \\
\text { ampla; dinamismo. } \\
\text { 4.7. Habilidades interpessoais: } \\
\text { bom relacionamento interpessoal. } \\
\text { 4.8. Habilidades de comunicação: } \\
\text { ser comunicativo. }\end{array}$ \\
\hline
\end{tabular}

Este cargo é ocupado por um funcionário.

Para estas atividades, o R/3 é utilizado apenas para consultar algumas informações. Aumentou a atividade de atender a Receita Federal, porque antes os fiscais vinham até a empresa e procuravam os documentos; hoje eles encaminham um ofício e a empresa é que deve montar o processo e procurar esses documentos. A Receita Federal passou a solicitar informações sobre os fornecedores, visto que a Empresa 1 é modelo e fica mais fácil fiscalizar com essas informações. Na opinião desse funcionário, essa mudança de procedimento não foi motivada pela implementação do R/3. 
Quadro no 1.4 - Descrição do cargo Analista Contábil

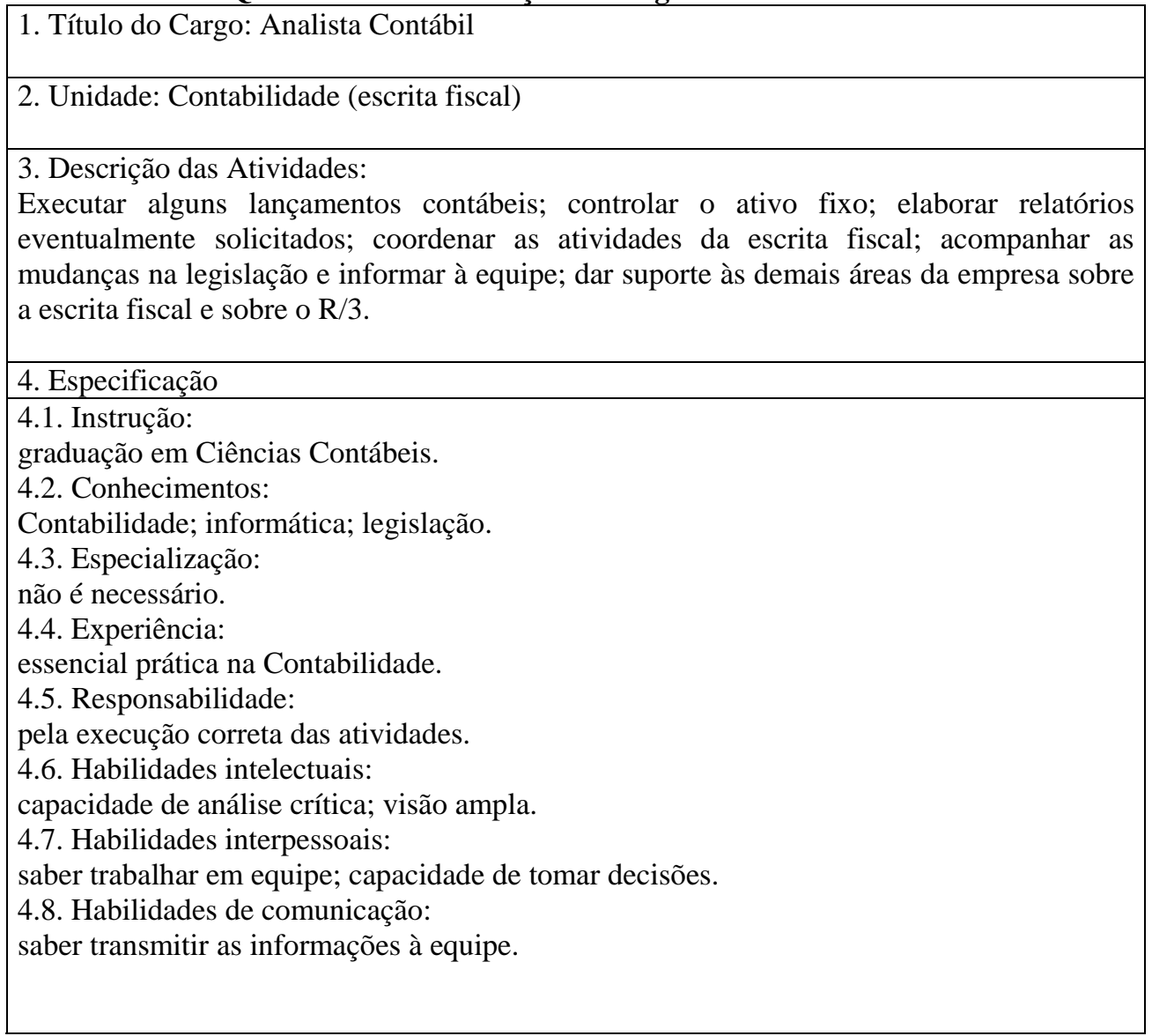

As atividades desse cargo são executadas por três pessoas. Um dos ocupantes informou que o nome do cargo era analista de escrita fiscal, mas nos documentos da empresa consta analista contábil.

Uma mudança que ocorreu pela implementação do R/3 é que os dados ficam disponíveis para consulta por mais tempo. Um ocupante do cargo afirmou: "Facilitou a movimentação de lançamentos contábeis. A facilidade do R/3 é que você pode rastrear. Antes, o lançamento ficava no sistema por 3 meses, depois ia para os livros. Hoje não, nós temos uma história.” Atribui ênfase à facilidade para obter e visualizar informações, procurar documentos. Também comenta que o R/3 facilitou a atividade de inventário do ativo fixo.

Para realizar estas atividades, é necessário utilizar o Excel com os dados extraídos do R/3, já que este ERP não atende algumas necessidades de controles e relatórios.

Um dos ocupantes do cargo participou da implementação como usuário-chave e agora é responsável por dar suporte sobre o R/3 aos demais funcionários. Na opinião dessa pessoa, esta foi a única atividade que aumentou depois da vinda deste sistema. "A diferença que eu vejo, depois do R/3, é que, além de tudo o que eu já fazia, eu tenho que dar suporte a outras pessoas também. Como eu participei do projeto tenho a obrigação de dar suporte.” 
Quadro no 1.5 - Descrição do cargo Auxiliar de Contabilidade II

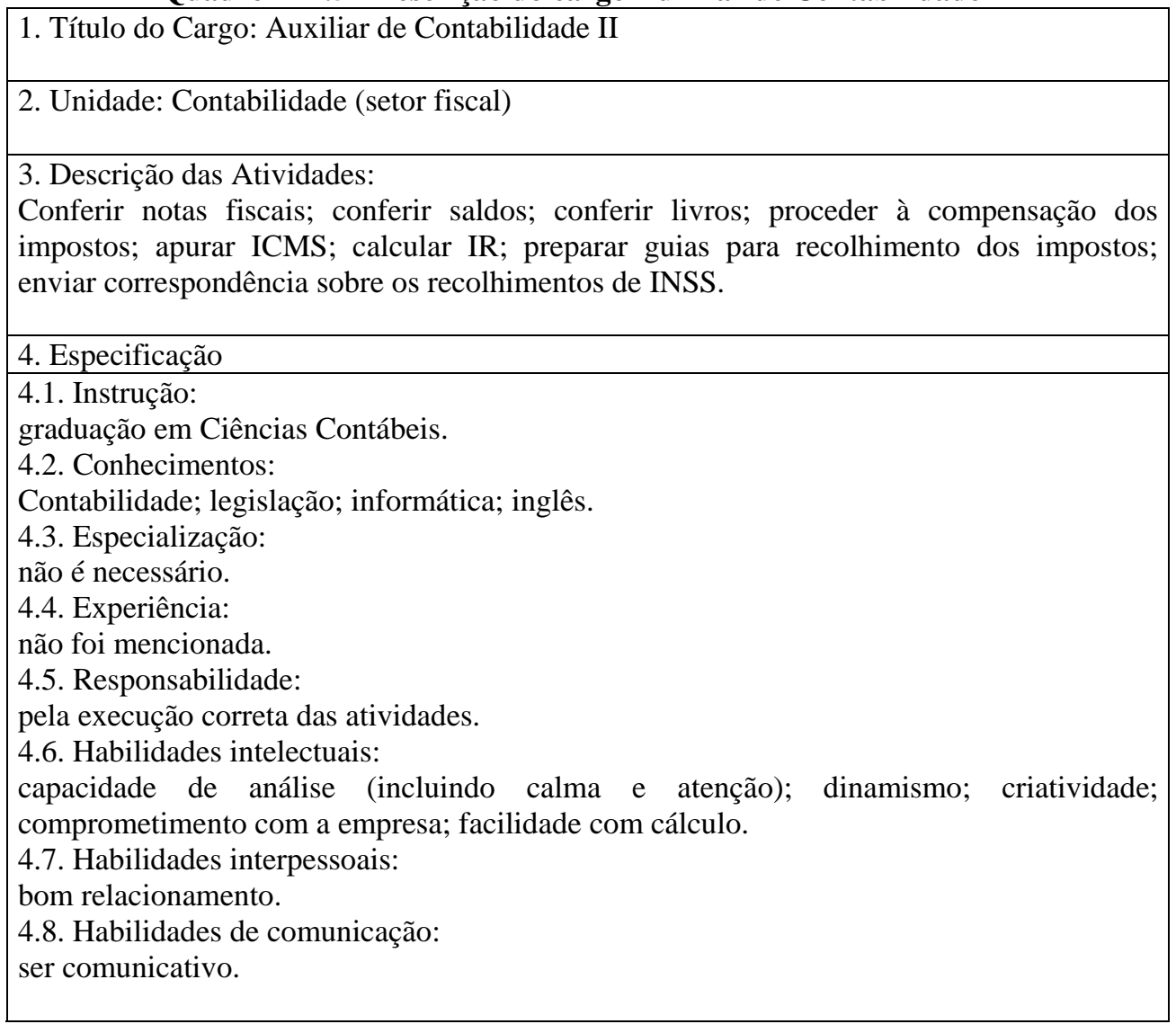

As atividades desse cargo estão distribuídas entre 4 funcionários. Um dos ocupantes informou que a nomenclatura correta é auxiliar contábil, mas na documentação da empresa está auxiliar administrativo II.

As mudanças que ocorreram após a implementação do R/3 foram para atender as alterações da legislação e não estão relacionadas ao sistema. O sistema facilitou a execução das atividades porque proporciona mais rapidez e facilidade para localizar informações, mas não provocou nenhuma alteração no tipo de atividade desenvolvida neste cargo.

Também não houve alteração da necessidade por conhecimentos e habilidades após o R/3. Um dos ocupantes do cargo, que tem formação superior em Ciências Contábeis, acredita que o importante é a pessoa ser dinâmica e criativa. 
Quadro no 1.6 - Descrição do cargo Auxiliar de Contabilidade II

1. Título do Cargo: Auxiliar de Contabilidade II

2. Unidade: Contabilidade (setor escrita fiscal)

3. Descrição das Atividades:

Conferir lançamentos a partir do documento fonte; controlar tudo o que está no armazém; separar e controlar notas fiscais de serviço; atender solicitações da diretoria; dar suporte técnico aos demais funcionários da empresa; executar os procedimentos de fechamento contábil do período, inclusive a elaboração das demonstrações contábeis; executar serviços diversos de secretaria, como reserva de hotel.

4. Especificação

4.1. Instrução:

técnico ou estar cursando graduação em Ciências Contábeis.

4.2. Conhecimentos:

Contabilidade; matemática financeira; legislação; impostos e contribuições; básico em informática.

4.3. Especialização:

não é necessário.

4.4. Experiência:

indispensável a prática em Contabilidade.

4.5. Responsabilidade:

pela execução correta das atividades.

4.6. Habilidades intelectuais:

capacidade de análise crítica.

4.7. Habilidades interpessoais:

não foi mencionada.

4.8. Habilidades de comunicação:

não foi mencionada.

As atividades estão divididas entre dois funcionários. Um dos ocupantes do cargo informou que a nomenclatura correta é auxiliar de Contabilidade II, embora nos documentos da empresa conste como auxiliar administrativo II.

Além do R/3, são utilizados o Word,para digitação de correspondências, e também o Excel, para controles, tendo como base os dados extraídos do R/3.

Segundo um dos ocupantes do cargo, as atividades não mudaram, o mais difícil foi aprender a utilizar o sistema. 
Quadro no 1.7 - Descrição do cargo Auxiliar de Contabilidade II

1. Título do Cargo: Auxiliar de Contabilidade II

2. Unidade: Contabilidade (coligada)

3. Descrição das Atividades:

Receber os documentos; conferir as notas fiscais e registrar as transações de uma das coligadas, inclusive das atividades de exportação; conferir alguns lançamentos feitos nesta coligada; calcular e controlar a variação cambial; calcular depreciação; fazer a importação dos dados da folha de pagamento; executar todo o processo de fechamento contábil, inclusive elaboração das demonstrações contábeis; fazer os registros referentes às transações de exportação de outra coligada.

4. Especificação

4.1. Instrução:

graduação em Ciências Contábeis.

4.2. Conhecimentos:

Contabilidade; legislação; impostos e contribuições; básico em informática; inglês.

4.3. Especialização:

não é necessário.

4.4. Experiência:

indispensável a prática em Contabilidade.

4.5. Responsabilidade:

pela execução correta das atividades.

4.6. Habilidades intelectuais:

capacidade de análise crítica.

4.7. Habilidades interpessoais:

bom relacionamento.

4.8. Habilidades de comunicação:

não foi mencionada.

Segundo o ocupante do cargo, o R/3 facilitou o trabalho. 
Quadro no 1.8 - Descrição do cargo Auxiliar de Escritório

\begin{tabular}{|l|}
\hline 1. Título do Cargo: Auxiliar de Escritório \\
\hline 2. Unidade: Contabilidade \\
\hline 3. Descrição das Atividades: \\
Atender às solicitações da Receita Federal sobre informações dos fornecedores; calcular o \\
IR retido na fonte e fazer as conferências necessárias; controlar a manutenção dos \\
equipamentos da área de Contabilidade; controlar o pedido de materiais de consumo da \\
área de Contabilidade; conferir as guias de recolhimento do ICMS na barreira; auxiliar na \\
atividade de arquivo; controlar as duplicatas a receber e faturamento de uma das coligadas; \\
conferir a prévia de credores e devedores relacionado com as comissões; controlar as \\
contas de credores e devedores dos descontos comerciais. \\
\hline 4. Especificação \\
\hline 4.1. Instrução: \\
graduação em Ciências Contábeis. \\
4.2. Conhecimentos: \\
Contabilidade; legislação fiscal; inglês; informática. \\
4.3. Especialização: \\
não é necessário. \\
4.4. Experiência: \\
não foi mencionada. \\
4.5. Responsabilidade: \\
pela execução correta das atividades. \\
4.6. Habilidades intelectuais: \\
capacidade de análise crítica; comprometimento; capacidade de tomada de decisão. \\
4.7. Habilidades interpessoais: \\
não foi mencionada. \\
4.8. Habilidades de comunicação: \\
saber transmitir as informaços. \\
\end{tabular}

Estas atividades estão distribuídas entre duas pessoas. Segundo os ocupantes do cargo, o R/3 facilitou o trabalho. 
Quadro no 1.9 - Descrição do cargo Auxiliar Administrativo

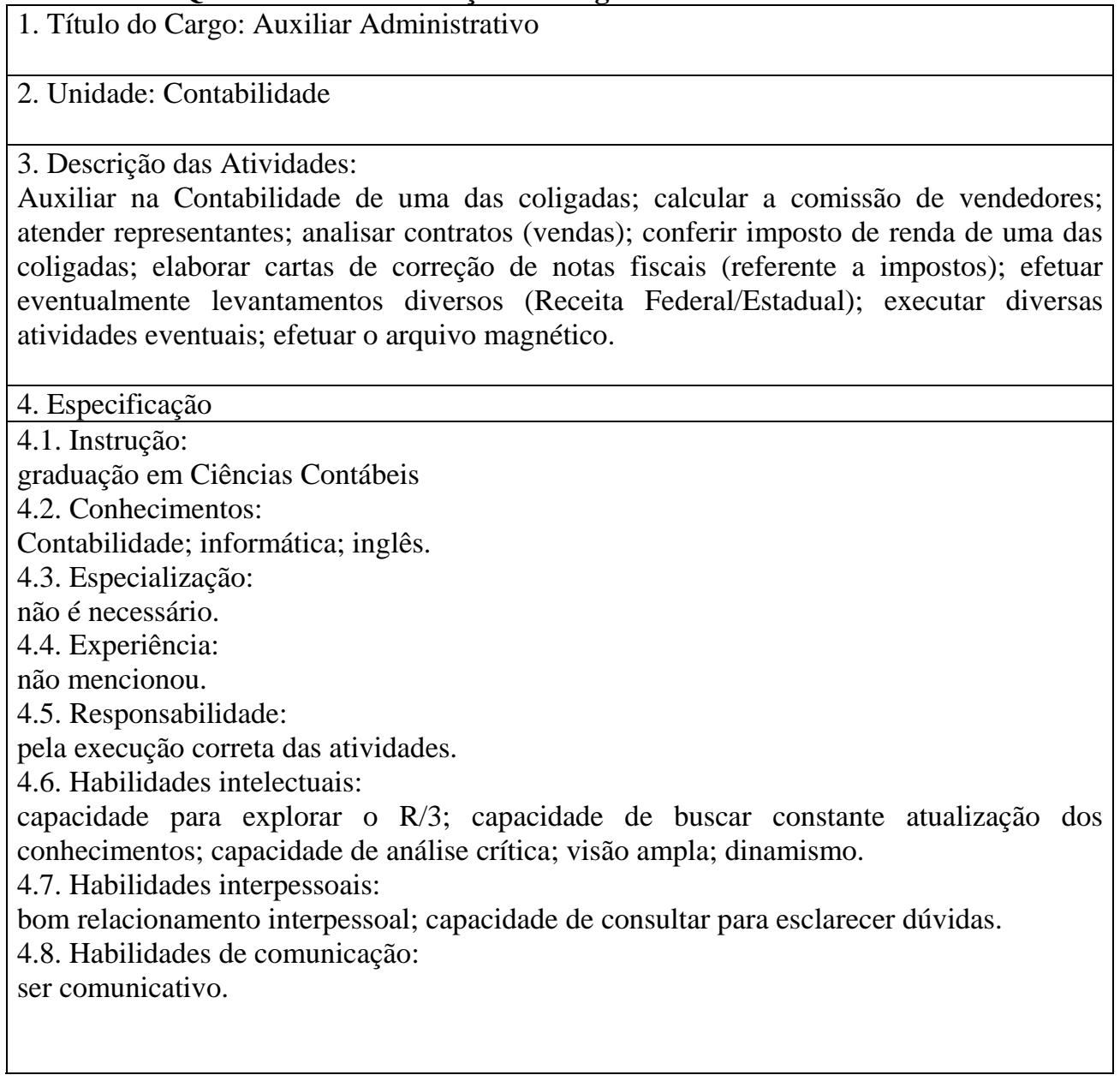

Estas atividades estão distribuídas entre duas pessoas.

Um dos funcionários comentou que o R/3 facilitou a execução das atividades, principalmente as referentes ao arquivo magnético, às cartas de correção e ao levantamento das notas fiscais. Não houve introdução de atividade nova ou exclusão de atividade já prevista para este cargo.

\section{Descrições dos cargos relacionados à Contabilidade Gerencial}

Foi criado o setor de controladoria, logo após a implementação do R/3, para concentrar as atividades que são executadas com a utilização do módulo $\mathrm{CO}$, as quais referem-se à Contabilidade Gerencial.

As atividades referentes a orçamento, a relatórios gerenciais e a investimentos eram realizadas na área de planejamento. Já as atividades referentes a custos eram realizadas na área de Contabilidade. A controladoria concentrou todas essas atividades, com a utilização do módulo CO do $\mathrm{R} / 3$. 
Quadro no 2.1 - Descrição do cargo Gerente de Auditoria e Controladoria

1. Título do Cargo: Gerente de Auditoria e Controladoria

2. Unidade: Controladoria

3. Descrição das Atividades:

Coordenar as atividades da equipe de auditoria e da controladoria; gerenciar a área de controladoria e de Contabilidade e participar do dia-a-dia onde requer tomada de decisão; participar da análise do relatório elaborado no final do mês; fazer a apresentação dos relatórios para a diretoria; trimestralmente fazer, junto com a diretoria e o colegiado, a avaliação dos relatórios.

4. Especificação

4.1. Instrução:

graduação em Ciências Contábeis.

4.2. Conhecimentos:

Contabilidade; análise de retorno de investimento; legislação; tributos.

4.3. Especialização:

não mencionou.

4.4. Experiência:

essencial prática na Contabilidade.

4.5. Responsabilidade:

pela execução correta das atividades.

4.6. Habilidades intelectuais:

raciocínio lógico; capacidade de análise crítica; ser ético.

4.7. Habilidades interpessoais:

bom relacionamento interpessoal; capacidade para trabalhar com equipes.

4.8. Habilidades de comunicação:

capacidade de transmitir informações.

O ocupante do cargo acredita que não houve alteração das atividades com a implementação do $\mathrm{R} / 3$. 
Quadro no 2.2 - Descrição do cargo Assistente de Controladoria

\begin{tabular}{l}
\hline 1. Título do Cargo: Assistente de Controladoria \\
\hline 2. Unidade: Controladoria \\
\hline 3. Descrição das Atividades: \\
Elaborar custos; acompanhar as apropriações dos gastos gerais (Empresa 1 e duas \\
coligadas); gerenciar o cadastro de materiais e implantar a visão do CO; elaborar o \\
orçamento (Empresa 1 e uma coligada); dar suporte de informações sobre os \\
procedimentos no R/3 para as áreas; executar treinamentos sobre o R/3. \\
\hline 4. Especificação \\
\hline 4.1. Instrução: \\
graduação em Ciências Contábeis ou Administração. \\
4.2. Conhecimentos: \\
Contabilidade relacionada a custos; informática e inglês. \\
4.3. Especialização: \\
não é necessário. \\
4.4. Experiência: \\
não mencionou. \\
4.5. Responsabilidade: \\
pela execução correta das atividades. \\
4.6. Habilidades intelectuais: \\
raciocínio lógico; capacidade de análise crítica. \\
4.7. Habilidades interpessoais: \\
bom relacionamento interpessoal. \\
4.8. Habilidades de comunicação: \\
ser comunicativo. \\
\end{tabular}

Houve alteração na forma de elaboração do orçamento. Antes do R/3, os dados eram extraídos dos balancetes vindos da Contabilidade. Hoje, todos os dados estão no R/3 e podem ser consultados diariamente (os balancetes são fechados diariamente).

Também mudou a forma de calcular os custos. Segundo o ocupante do cargo, “[...] antes não tinha alocação de custos e hoje é muito boa, tudo é registrado e apropriado.”

Atualmente, a informação fornecida pode ser mais detalhada, o que para o pessoal operacional provocou aumento de trabalho, uma vez que agora é preciso registrar tudo no sistema.

Segundo o ocupante do cargo, a habilidade de relacionamento interpessoal foi reforçada com o R/3, em função da necessidade de estar mais próximo das áreas, principalmente da área de produção. 
Quadro no 2.3 - Descrição do cargo Analista de Controladoria

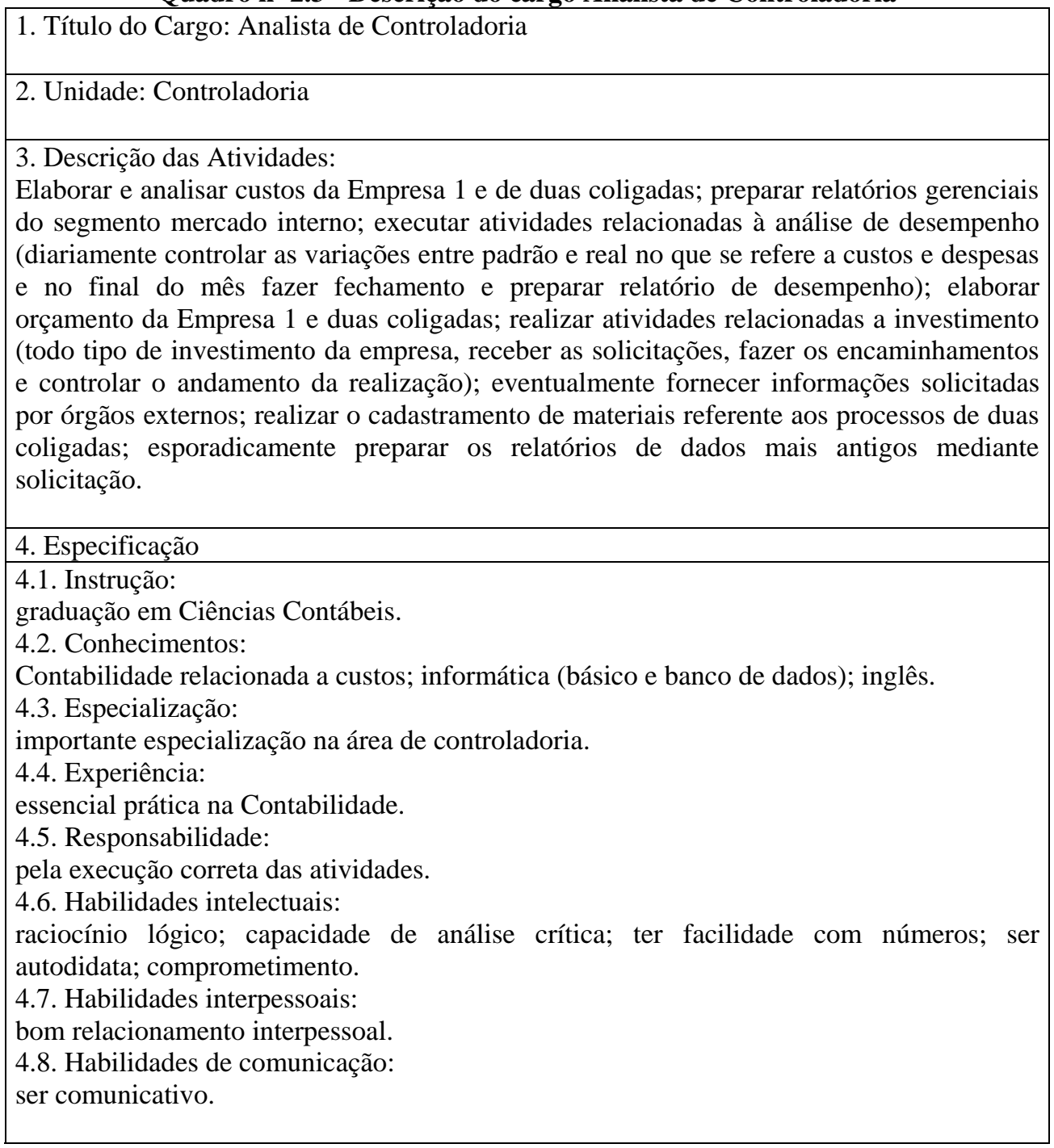

As atividades deste cargo são distribuídas entre três (3) pessoas.

Segundo um ocupante deste cargo, anteriormente ao R/3, não havia necessidade de nível superior como grau de instrução e agora é necessário. Também houve necessidade de conhecimento de inglês.

O R/3 facilitou as atividades e permitiu a elaboração de diversas formas de análise, inclusive investigar os detalhes das variações. Segundo um dos entrevistados, “Antes eram relatórios fechados e o R/3 tem a opção para definir relatórios com vários formatos.” Todavia, em diversos casos, é preciso utilizar o Excel para elaborar alguns relatórios, cujos dados são extraídos do próprio $\mathrm{R} / 3$.

Antes do R/3, estas atividades exigiam muito trabalho de digitação e, com o sistema, o trabalho é mais de análise. 


\section{APÊNDICE 6}

\section{DESCRIÇÕES DE CARGOS DO CASO 2}

As descrições dos cargos da área de Contabilidade da Empresa 2 foram desenvolvidas tendo por base as informações fornecidas pelos ocupantes de cada cargo, as informações fornecidas pelo contador sobre os mesmos cargos e as informações obtidas nas descrições de cargos elaboradas pela Empresa 2. Tais descrições são referentes ao período anterior à implementação do R/3 e também ao período posterior, permitindo comparação e verificação de modificações. As descrições de cargos elaboradas pela empresa referentes aos cargos de encarregado contábil-fiscal, analista de custos, auxiliar administrativo e assessor de custos não foram fornecidas pela empresa. Nestes quatro casos, as descrições apresentadas abaixo, nos quadros 1.2, 1.7, 1.9 e 2.1, foram elaboradas tendo por base apenas as informações dos ocupantes dos cargos e as informações fornecidas pelo contador.

É importante esclarecer que não foi possível seguir fielmente as descrições de cargos elaboradas pela Empresa 2 porque, segundo os funcionários, elas não estão muito atualizadas. Algumas das atividades que realizam ainda não estão ali contempladas e outras que estão previstas não são realizadas. Dessa forma, a pesquisadora desenvolveu as descrições de cargos, apresentadas na seqüência, cruzando os dados coletados junto aos funcionários, com o contador e nas descrições de cargos elaboradas pela Empresa 2, com o intuito de evidenciar o que realmente está previsto em cada cargo.

Da mesma forma que na Empresa 1 (caso 1), na Empresa 2 foram observadas certas restrições referentes às dificuldades dos ocupantes dos cargos em lembrar-se de suas atividades e em expressar-se adequadamente acerca das habilidades relacionadas aos cargos. Também houve certa dificuldade em fazer clara separação entre os conhecimentos e habilidades exigidos pelos cargos e os que os funcionários possuíam.

Todavia, a pesquisadora acredita que essas restrições não prejudicaram os resultados, visto que mesmo tendo tais dificuldades, quando questionados sobre as mudanças, os entrevistados responderam prontamente. Além disso, a descrição de cargos elaborada pela Empresa 2, 
juntamente com as observações feitas pela pesquisadora, possibilitou a verificação das informações fornecidas pelos entrevistados.

Encontram-se, a seguir, as descrições dos cargos desenvolvidas pela pesquisadora que estão agrupadas em cargos da área de Contabilidade Financeira e cargos da área de controladoria. Após cada descrição, são comentadas as alterações percebidas nos cargos (atividades, conhecimentos e habilidades), tendo em vista a implementação do R/3.

1. Descrições dos cargos da área de Contabilidade Financeira

A área de Contabilidade Financeira conta com uma estrutura de seis cargos que são: supervisor contábil, encarregado contábil-fiscal, assistente contábil-fiscal (níveis I, II e III), assistente de materiais (nível I), analista de custos e auxiliar administrativo (nível I).

O cargo assistente contábil-fiscal é bastante amplo e prevê atividades nos setores fiscal, escrita fiscal e controle patrimonial. Ele é resultado da unificação dos cargos auxiliar contábil, auxiliar fiscal e auxiliar de patrimônio. O enquadramento nos níveis I, II e III não segue o critério de qual atividade cada pessoa desempenha, mas sim de quanto tempo de experiência tem na empresa.

Como as atividades inerentes ao cargo são bastante distintas e buscando uma melhor visualização das atividades desenvolvidas em cada setor, foram elaboradas descrições de cargos separadas (quadros 1.3, 1.4, 1.5 e 1.6). 
Quadro no 1.1 - Descrição do cargo Supervisor Contábil

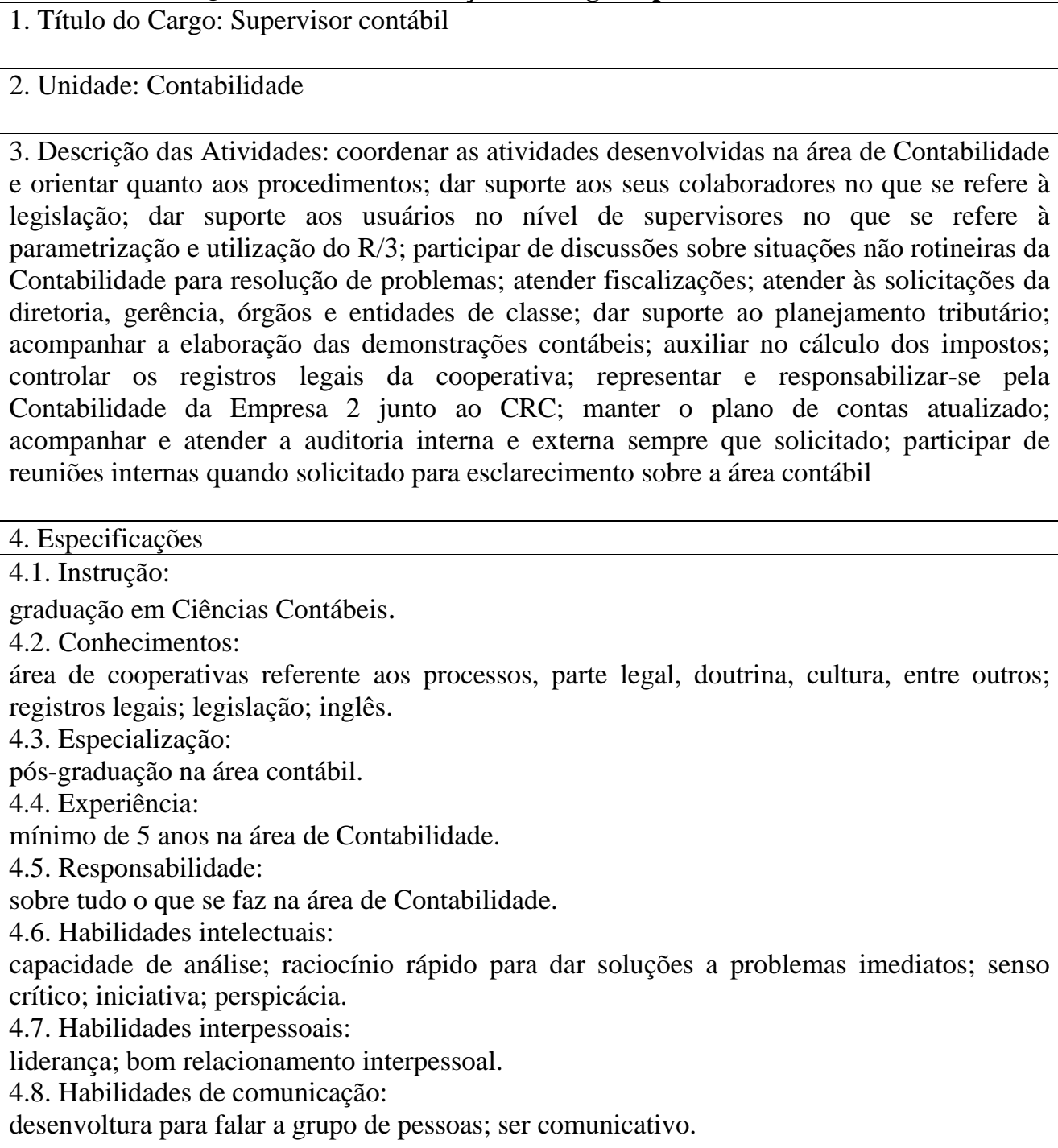

Este cargo é ocupado por um funcionário.

O contador deixou claro que não faz atividades operacionais. Embora tenha assumido esse cargo cerca de 1 ano após a implementação do R/3, teve condições de informar que o perfil do cargo mudou e outros funcionários da área contábil, que já trabalhavam ali antes do R/3, confirmaram essa informação.

Segundo informações dos funcionários, antes do R/3 ser implementado, o contador centralizava bastante as atividades referentes aos impostos federais e a relatórios gerenciais e se envolvia com as atividades operacionais em geral. Com o R/3, o contador está envolvido com atividades de orientação e coordenação junto aos seus colaboradores e suporte de informações aos demais funcionários da empresa, conforme pode ser visto na descrição de cargos. Na descrição deste cargo, fornecida pela Empresa 2, está prevista a atividade de 
apuração de impostos federais, mas ela não é, de fato, desenvolvida pelo contador. Novas atividades referentes a suporte aos funcionários sobre problemas relacionados ao R/3 foram incluídas.

Sobre as causas da mudança, duas puderam ser identificadas: a implementação do R/3 que provocou alterações na forma de desenvolver as atividades da área contábil e também o perfil da pessoa do contador, que é mais descentralizador. Uma funcionária comentou que, após o R/3 ser implementado, a contadora já não fazia mais tantas atividades operacionais, estava mais com relatórios. Quando ela saiu da empresa e outro contador assumiu, descentralizou também a emissão de relatórios.

Com relação às habilidades, na revisão dos cargos feita pela Empresa, após a implementação do R/3, foram consideradas como necessárias, além das já previstas até então, capacidade de análise, senso crítico e habilidades numéricas. Na opinião do contador, além destas que são realmente importantes, outras que já eram necessárias e adquiriram maior importância após o R/3, são o relacionamento interpessoal e a facilidade de comunicação. Isso porque o contador passou a estar mais em contato com todas as áreas da empresa e seu trabalho depende em grande parte do adequado desempenho do trabalho dos demais colaboradores da empresa. 
Quadro no 1.2 - Descrição do cargo Encarregado Contábil-fiscal

\begin{tabular}{|l|}
\hline 1. Título do Cargo: Encarregado Contábil-fiscal \\
\hline 2. Unidade: Contabilidade \\
\hline 3. Descrição das Atividades: manter a legislação atualizada, orientando os colaboradores \\
quanto às alterações; acompanhar e orientar o trabalho dos colaborados sob sua supervisão; \\
desenvolver e coordenar planejamento de treinamento contábil dos usuários do R/3; dar \\
suporte aos demais colaboradores da empresa quanto a orientações sobre legislação e \\
procedimentos do R/3, principalmente no que se refere a impostos; fazer o cálculo de alguns \\
tributos federais. \\
\hline 4. Especificações \\
\hline 4.1. Instrução: \\
graduação em Ciências Contábeis. \\
4.2. Conhecimentos: \\
legislação; informática; inglês; conhecimento em R/3. \\
4.3. Especialização: \\
não mencionou. \\
4.4. Experiência: \\
2 anos de experiência na área. \\
4.5. Responsabilidade: \\
sobre suas atividades; sobre as atividades de seus subordinados. \\
4.6. Habilidades intelectuais: \\
atenção concentrada; capacidade de análise; habilidades numéricas; senso crítico. \\
4.7. Habilidades interpessoais: \\
bom relacionamento interpessoal; gerenciamento de pessoas; liderança. \\
4.8. Habilidades de comunicação: \\
facilidade em comunicação.
\end{tabular}
facilidade em comunicação.

Este cargo é ocupado por uma funcionária.

Antes do R/3, havia o cargo de encarregado fiscal e encarregado contábil. Com a implementação do sistema houve uma reorganização e os dois cargos foram unificados neste, denominado encarregado contábil-fiscal. As atividades operacionais previstas para os dois cargos ficaram com o cargo assistente contábil-fiscal.

A pessoa que ocupava o cargo de encarregado fiscal assumiu esse novo cargo e a pessoa que ocupava o cargo encarregado contábil desligou-se da empresa por motivos particulares.

Os cargos extintos previam muitas atividades operacionais, como apuração de impostos com confecção das guias de recolhimento e dos formulários exigidos na legislação. Também previam treinamento aos colaboradores da área. Com o R/3, as atividades envolvem mais a coordenação, orientação quanto a procedimentos e análise.

A atividade mudou muito. Segundo um dos ocupantes: "No começo eu pensei, meu Deus, eu estou me tornando improdutiva - porque estava acostumada a executar, executar, executar e quando tem que começar a parar, pensar e planejar você tem um pouco de dificuldade.”

Com a unificação dos cargos, a equipe sob responsabilidade do encarregado aumentou e agora 
este é responsável pela equipe contábil, fiscal e de patrimônio. Segundo a ocupante deste cargo, as principais mudanças relacionadas às habilidades são quanto ao relacionamento interpessoal e à liderança, já que antes do R/3 coordenava 4 pessoas e depois ficou com 13 pessoas. Também exigiu-se mais dedicação aos treinamentos dos colaboradores: “A cooperativa tem várias unidades espalhadas e cada unidade tem uma pessoa responsável pelo registro das notas, pelo envio de documentos e tem que ser coordenado pela Contabilidade. Os treinamentos envolvem todas essas pessoas.”

Com relação aos conhecimentos, tornou-se necessário entender mais de informática, principalmente de Excel, pois a maioria dos relatórios são emitidos com apoio deste programa, com dados extraídos do R/3. 
Quadro nº 1.3 - Descrição do cargo Assistente Contábil-fiscal I

\begin{tabular}{|c|}
\hline 1. Título do Cargo: Assistente Contábil-fiscal I \\
\hline 2. Unidade: Contabilidade (setor contabilização) \\
\hline $\begin{array}{l}\text { 3. Descrição das Atividades: } \\
\text { realizar controle de estoque; executar a conciliação de documentos contábeis principalmente } \\
\text { relacionados ao estoque e orientar quanto aos ajustes necessários; orientar e acompanhar os } \\
\text { trabalhos de inventário (estoque) de toda a empresa; controlar e contabilizar as variações } \\
\text { identificadas nos estoques; proceder os lançamentos de ajustes do estoque, quando } \\
\text { necessário; preparar relatórios eventuais, quando solicitado; emitir livro diário, atendendo à } \\
\text { legislação; dar suporte aos demais colaboradores da empresa quanto a orientações sobre } \\
\text { Contabilidade e procedimentos do R/3, principalmente no que se refere a estoques e alguns } \\
\text { aspectos fiscais. }\end{array}$ \\
\hline 4. Especificações \\
\hline $\begin{array}{l}\text { 4.1. Instrução: } \\
\text { graduação em Ciências Contábeis. } \\
\text { 4.2. Conhecimentos: } \\
\text { informática, principalmente Excel; legislação. } \\
\text { 4.3. Especialização: } \\
\text { não é necessário. } \\
\text { 4.4. Experiência: } \\
\text { desejável } 2 \text { anos de experiência. } \\
\text { 4.5. Responsabilidade: } \\
\text { sobre as atividades da área. } \\
\text { 4.6. Habilidades intelectuais: } \\
\text { ser dinâmico; ter iniciativa em buscar soluções; análise crítica; afinidade com cálculos. } \\
\text { 4.7. Habilidades interpessoais: } \\
\text { bom relacionamento interpessoal. } \\
\text { 4.8. Habilidades de comunicação: } \\
\text { facilidade de comunicação; facilidade para falar para grupos de pessoas. }\end{array}$ \\
\hline
\end{tabular}

Este cargo é ocupado por uma funcionária.

Conforme comentado anteriormente, esse cargo é bastante amplo, abrangendo as atividades ligadas à contabilização de forma geral, à apuração e recolhimento de impostos e ao controle patrimonial.

No que se refere às atividades ligadas à contabilização, muitas atividades operacionais, como lançamentos contábeis, deixaram de ser executadas na área contábil, e agora as atividades desse cargo estão mais voltadas para o acompanhamento dos registros feitos e à orientação quanto aos procedimentos corretos e quanto aos ajustes, quando necessário. Segundo uma das funcionárias: "Você não tem que fazer, você tem que analisar e ver se está certo, ver o que pode trazer de benefício, ou críticas sobre os processos. Eu diria que na Contabilidade nossa função seria mesmo de suporte para as pessoas envolvidas naqueles processos.”

O controle de inventário passou a ser a atividade principal desse cargo, com o foco em coordenar equipes que farão o trabalho operacional de controle. Além disso, também se envolve eventualmente com algumas atividades do setor fiscal como apuração de tributos 
federais. Segundo a encarregada, “O assistente I é meio que um pivô que está preparado para assumir o cargo de encarregado, entende de Contabilidade, da área fiscal, estoque.”

A mudança maior foi no "como fazer”. O trabalho hoje é mais no sentido de analisar as contas do estoque. "Dá para controlar melhor porque tem ferramentas para isso”, afirma uma funcionária.

A novidade ficou a cargo da conscientização da integração que existe entre as áreas da empresa e sua importância para a Contabilidade. A funcionária deste cargo comentou: "Você começa a ter conhecimento de outras funções de outras pessoas, que estão envolvidas com seu trabalho, mas que antes você não conhecia. Agora ficou mais fácil observar que as áreas são interligadas e você começa a conhecer outras áreas e a relação que elas têm com seu trabalho.” A forma como o R/3 é estruturado proporciona essa visão sistêmica. 
Quadro no 1.4 - Descrição do cargo Assistente Contábil-fiscal II

\begin{tabular}{|l|}
\hline 1. Título do Cargo: Assistente Contábil-fiscal II \\
\hline 2. Unidade: Contabilidade (setor contabilização) \\
\hline 3. Descrição das Atividades: \\
Fazer o acompanhamento da conta de caixa; fazer a conciliação de algumas contas (por \\
exemplo dos cartões de crédito e vale-refeição); fazer provisões no final do mês atendendo \\
ao regime de competência; auxiliar na emissão de relatórios, quando solicitado; fazer guias \\
de recolhimento de alguns impostos federais (pis, cofins e inss); fazer uma parte do registro \\
legal. \\
\hline 4. Especificações \\
\hline 4.1. Instrução: \\
graduação em Ciências Contábeis. \\
4.2. Conhecimentos: \\
Excel; Word; bom vocabulário; legislação. \\
4.3. Especialização: \\
não é necessário. \\
4.4. Experiência: \\
desejável 2 anos de experiência \\
4.5. Responsabilidade: \\
sobre as atividades da área. \\
4.6. Habilidades intelectuais: \\
senso de organização; dinamismo; ter iniciativa; ser paciente; análise crítica; facilidade com \\
números/cálculos;facilidade em redação (desenvolvimento e interpretação de texto). \\
4.7. Habilidades interpessoais: \\
bom relacionamento interpessoal. \\
4.8. Habilidades de comunicação: \\
facilidade em comunicação.
\end{tabular}

Este cargo é ocupado por um funcionário.

Ainda no setor de contabilização, mas no nível II, as atividades tiveram mudança no "como fazer”. Antes do R/3, existia muito trabalho de conciliação de contas e hoje poucas contas são conciliadas. Com a redução de tais atividades, o cargo assumiu outras atividades que eram desempenhadas pelo contador, como é o caso do acompanhamento e controle dos registros legais (diversas exigências dos órgão públicos para o funcionamento da empresa, principalmente aquelas ligadas à preservação do meio ambiente)

Também realizava atividades relacionadas ao controle de caixa, e continua com tais atividades, mas o processo agora é diferente. Segundo a funcionária: “[...] mudou bastante porque antes do R/3 a gente só operacionalizava - com o R/3 você não faz mais o operacional, tem que fazer análises, resolver problemas, dar suporte aos demais funcionários.” E completa: “Antes era muito apurado, ficava à noite trabalhando, final de semana, era sagrado [...] e hoje não.”

As mudanças referentes às habilidades ficam a cargo de uma ênfase maior na análise crítica e relacionamento interpessoal. As demais atividades já eram necessárias antes da implementação do R/3. 
Quadro no 1.5- Descrição do cargo Assistente Contábil-fiscal II

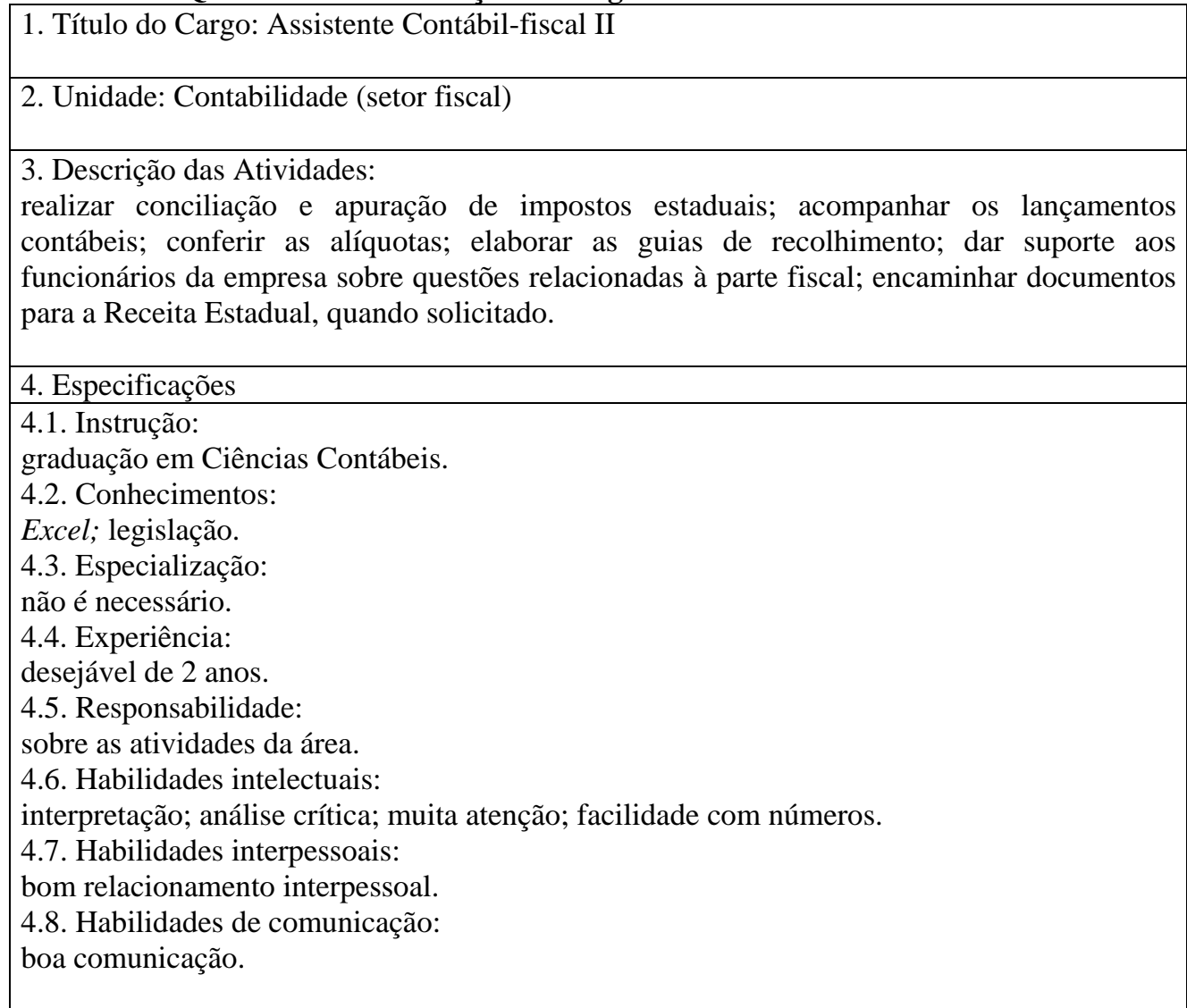

Este cargo é ocupado por dois funcionários. De acordo com a funcionária da área, a parametrização do R/3, no que diz respeito a ICMS (imposto sobre circulação de mercadorias e prestação de serviços), apresenta problemas e foi necessário desenvolver alguns controles no Excel para conciliar e garantir valores corretos. Houve uma certa frustração, pois antes do R/3 era complicado fazer a apuração dos impostos e a expectativa era que os procedimentos todos fossem automatizados no sistema, inclusive a emissão das guias de recolhimento: “[...] esperava que a apuração saísse pronta, você apertava um botão, já transmitia para você, e na realidade não é assim.” Todavia, na opinião dessa funcionária, mesmo com esse inconveniente, depois do R/3 as atividades da área fiscal ficaram mais simples e rápidas. Antes, era preciso conferir todas as notas e se existia algum erro tinha que resolver, mas como o processamento ocorria à noite era preciso esperar o dia seguinte para verificar se tinha ficado tudo certo. Também era muito difícil rastrear a origem de um lançamento.

Segundo uma funcionária do setor e verificando a descrição de cargos elaborada pela Empresa 2, com o R/3 mudou o jeito de realizar as atividades. Algumas atividades acabaram, mas não houve nenhuma novidade, nem tampouco quanto aos conhecimentos e habilidades exigidos para o cargo. 
Quadro no 1.6 - Descrição do cargo Assistente Contábil-fiscal III

\begin{tabular}{|l|}
\hline 1. Título do Cargo: Assistente Contábil-fiscal III \\
\hline 2. Unidade: Contabilidade (controle de patrimônio) \\
\hline 3. Descrição das Atividades: \\
conferir o registro de todos os bens que entram na empresa; providenciar plaqueteamento \\
dos bens; realizar o controle do patrimônio; coordenar o levantamento de todos os bens da \\
cooperativa; providenciar a venda de móveis não operacionais; conciliar as contas do \\
imobilizado; fazer arquivo das notas referentes a imobilizado; controlar a documentação dos \\
imóveis; realizar e controlar o cadastro dos bens por matrícula do imóvel onde os bens estâ \\
alocados; acompanhar os custos referentes à construção de imobilizado providenciando seu \\
adequado registro contábil e averbação. \\
\hline 4. Especificações \\
\hline 4.1. Instrução: \\
graduação em Ciências Contábeis. \\
4.2. Conhecimentos: \\
conhecimento da empresa; legislação; R/3; Excel. \\
4.3. Especialização: \\
não é necessário. \\
4.4. Experiência: \\
desejável de 2 anos. \\
4.5. Responsabilidade: \\
sobre as atividades da área. \\
4.6. Habilidades intelectuais: \\
compreensão (bom raciocínio); dinamismo; ser calmo; ser organizado; capacidade de análise \\
de situações e resolução de problemas; senso crítico. \\
4.7. Habilidades interpessoais: \\
bom relacionamento interpessoal. \\
4.8. Habilidades de comunicação: \\
facilidade de comunicação. \\
\end{tabular}

Este cargo é ocupado por um funcionário.

Neste cargo não houve mudança no tipo de atividade e sim no modo de realizar tais atividades. Facilitou o trabalho, uma vez que o sistema anterior fornecia poucos recursos e o controle era muito trabalhoso, tanto que ficou muito tempo sem atualizar o imobilizado.

Na Contabilidade, duas pessoas cuidam do imobilizado, e nas unidades há no mínimo 2 pessoas em cada uma delas que foram treinadas para controlar o imobilizado. Essas pessoas fazem o levantamento e encaminham os relatórios para a Contabilidade que desenvolve todo o controle.

É importante esclarecer que apenas uma pessoa ocupa o cargo assistente contábil-fiscal III (setor controle de patrimônio). O outro funcionário deste setor está ali há apenas 2 meses e por enquanto ocupa o cargo de auxiliar contábil. Segundo informações de uma funcionária, é possível que mais uma pessoa seja designada para tais atividades, visto que está apenas começando o trabalho de levantamento de todos os bens da empresa, o que vai demandar muito tempo e recursos.

Com o R/3, além da maior facilidade na execução das atividades houve também uma 
valorização delas. Na opinião de uma funcionária: “O pessoal não dava a importância que tem. Hoje isso é muito importante, o imobilizado, e agora estão vendo que o furo é grande, o buraco é grande, do problema.” Para ela, era possível realizar o acompanhamento do imobilizado com o sistema anterior, mas não foi feito por falta de pessoal e tempo, porque era muito demorado.

Para a mudança de atitude relacionada ao patrimônio, a funcionária acredita que o sistema deixou o problema mais evidente: "Eu acho que o sistema ajudou bastante, porque ele mostrou todo o problema, porque quando pedia um relatório estava claro que a gente não tinha todos os móveis que estavam ali.” O problema ficou evidente também pelo custo (a depreciação passou a ser alocada aos setores conforme os bens listados para aquele setor e o pessoal começou a reclamar que não tinha bens que justificassem aquele valor).

Sobre o trabalho de levantamento do imobilizado, treinaram as pessoas nas unidades para colaborarem com o projeto.

Quanto a conhecimentos e habilidades, a necessidade foi exatamente conhecer o R/3, pois os demais itens previstos para o cargo já eram necessários antes da implementação deste sistema. 
Quadro no 1.7 - Descrição do cargo Analista de Custos

\begin{tabular}{|l|}
\hline 1. Título do Cargo: Analista de Custos \\
\hline 2. Unidade: Contabilidade \\
\hline 3. Descrição das Atividades: \\
Elaborar custos; analisar as variações entre custo padrão e real; proceder a revisão do custo \\
padrão; acompanhar alguns lançamentos contábeis relacionados a custos; auxiliar no \\
controle de estoque; auxiliar no controle do imobilizado; auxiliar nas ordens de manutenção \\
(serviço interno); dar suporte aos funcionários das empresas no que se refere a custos; \\
acompanhar o cadastro de materiais. \\
\hline 4. Especificações \\
\hline 4.1. Instrução: \\
graduação em Ciências Contábeis. \\
4.2. Conhecimentos: \\
conhecer os processos da empresa; informática, principalmente o Excel; bom conhecimento \\
de matemática financeira. \\
4.3. Especialização: \\
especialização na área de custos e controladoria. \\
4.4. Experiência: \\
experiência na área. \\
4.5. Responsabilidade: \\
sobre as atividades da área. \\
4.6. Habilidades intelectuais: \\
paciência; auto controle; análise crítica; habilidades numéricas. \\
4.7. Habilidades interpessoais: \\
bom relacionamento interpessoal. \\
4.8. Habilidades de comunicação: \\
ser comunicativo.
\end{tabular}

Este cargo é ocupado por um funcionário.

Passados três anos da implementação do R/3, as atividades relacionadas a custos já estão bastante estruturadas. Nos primeiros seis meses, de acordo com o funcionário da área, “[...] o fechamento era uma aventura, porque mudou muito em relação às movimentações, o pessoal fazia lançamentos de qualquer jeito e sempre dava erro no fechamento [...] não conseguia tempo nem para tentar melhorar nossa parte porque nós passávamos dez, quinze dias fechando balancete, e hoje fecha com 5 dias.”

O cadastro de materiais ainda apresenta alguns problemas que acabam refletindo em custos e, para minimizar o impacto, os materiais mais críticos são acompanhados durante o mês. Tais problemas, no entendimento do funcionário, são decorrentes da fase de parametrização e cadastro de todos os materiais. Continuamente são reavaliados os critérios de rateio. Em algumas situações, é detectado que o custo está errado, mas não tem como acertar dentro do mês: “Tem muita coisa que não tem como resolver, fez errado vai ter que manter errado, vai ter que ajustar na Contabilidade na mão e tentar arrumar no mês seguinte, porque não tem como mexer no material.” 
Anteriormente ao R/3, esse cargo não existia e a atividade de elaboração de custos era de responsabilidade da contadora, que não está mais na empresa, o que dificultou o levantamento de muitos detalhes sobre essa atividade. Custos gerenciais eram elaborados da seguinte maneira: em cada documento fiscal anotava-se, manualmente, o rateio dos gastos a cada centro de custos. Após essa distribuição, todos os dados eram digitados em diversas planilhas no Excel e, ao final do processo, o custo por centro de custos era obtido. Todo o processo demorava aproximadamente 20 dias e depois procedia-se as análises. Segundo o ocupante deste cargo: "Fazia cinco ou seis relatórios para fechar um, e ainda esse um chegava no final e dava uma diferença grande com a Contabilidade”, e continua: “Hoje facilitou porque antes precisava conferir nota por nota para identificar o erro e acertar as informações gerenciais com as da Contabilidade. Hoje, verificam-se alguns relatórios e já se identificam os problemas, se houver.”

Para trabalhar com custos no R/3, o ocupante do cargo precisou aprender sobre os processos da empresa e foi na fábrica para conhecer como funcionava e conseguir realizar sua função de elaboração de custos. Antes do R/3, também trabalhava com custos gerenciais mas não conhecia os processos. Ele afirma: “Tem que conhecer os processos.”

A dificuldade é que utiliza muito o Excel, já que os relatórios do R/3 não são muito adequados e também se torna muito demorado, pois são muitos usuários acessando o sistema que fica muito lento. Na opinião do funcionário: “Sem o Excel não dá para fazer muita coisa, você transfere tudo o que você quer de informação do R/3 pro Excel e trabalha lá dentro, é a melhor maneira."

Em termos de conhecimentos e habilidades, as principais alterações foram a necessidade de conhecer os processos da empresa e a necessidade de conhecer o Excel. 
Quadro no 1.8 - Descrição do cargo Auxiliar de Recepção de Materiais I

\begin{tabular}{|l|}
\hline 1. Título do Cargo: Auxiliar de Recepção de Materiais I \\
\hline 2. Unidade: Contabilidade (setor Célula de Entrada) \\
\hline 3. Descrição das Atividades: \\
conferir as notas fiscais de entrada com pedido de compra; fazer o cadastro das mercadorias \\
conforme a nota fiscal; verificar se as notas fiscais atendem a todas as exigências da \\
legislação. \\
\hline 4. Especificações \\
\hline 4.1. Instrução: \\
graduação em Ciências Contábeis. \\
4.2. Conhecimentos: \\
legislação;, processos da empresa; R/3. \\
4.3. Especialização: \\
não é necessário. \\
4.4. Experiência: \\
desejável de 2 anos. \\
4.5. Responsabilidade: \\
sobre as atividades da área. \\
4.6. Habilidades intelectuais: \\
senso crítico; criatividade; paciência; iniciativa para tomar decisões e resolver problemas; \\
capacidade de análise. \\
4.7. Habilidades interpessoais: \\
bom relacionamento interpessoal. \\
4.8. Habilidades de comunicação: \\
facilidade em comunicação.
\end{tabular}

Este cargo é ocupado por 5 funcionários. Foi criado cerca de um ano após a implementação do R/3, juntamente com a criação da Célula de Entrada. Para formar a equipe de trabalho, foram trazidas uma pessoa da área de Contabilidade e quatro pessoas das áreas de compras.

Os funcionários do setor começaram a trabalhar e ajustaram os processos para melhorar o desempenho. Eles verificaram o que podia ser melhorado, propuseram as mudanças e elas aconteceram. Segundo um dos ocupantes do cargo, a postura que eles adotaram foi de sempre observar o porquê de fazer cada atividade; se é realmente necessária, se tem outra forma melhor de fazer, sempre pensando que seu trabalho é o início de tantas outras atividades da empresa. Tentam sempre deixar o processo mais ágil e confiável. Consideram importante explorar o sistema para cada vez mais desenvolver melhor a sua atividade.

Por outro lado, existe uma preocupação da empresa em preparar esses funcionários desenvolvendo habilidades de relacionamento interpessoal e de atendimento, pois eles são o contato com pessoas externas da empresa.

Antes do R/3 e logo após sua implementação, as atividades previstas para esse cargo eram descentralizadas, realizadas em cada área de compras. Se ocorria algum problema com a mercadoria que estava sendo recebida, esse problema deveria ser solucionado após o recebimento da mercadoria. 
Agora não é mais assim. Segundo um dos funcionários: “O problema não entra mais na empresa. A mercadoria só entra na empresa quando tudo estiver solucionado.”

Essa mudança exigiu mais conhecimento de legislação, mais conhecimento do processo contábil e dos processos em geral da empresa, pois para conseguir classificar os materiais para cada área, centro de custo, natureza etc, precisa conhecer tanto de Contabilidade quanto da utilização daquele produto, além da parte tributária, pois o lançamento dos impostos é feito nesse momento. "Precisa entender dos processos fisicamente, como a legislação entende as movimentações e como realizar tudo no R/3. Conhecer o negócio. Uma pessoa para trabalhar nesse setor precisa antes ter passado por outros setores da empresa e conhecer o negócio. Dificilmente será contratado alguém de fora para trabalhar nesse setor”, diz um dos ocupantes do cargo.

A habilidade de relacionamento interpessoal também se tornou mais importante. 
Quadro no 1.9 - Descrição do cargo Auxiliar Administrativo I

\begin{tabular}{|l|}
\hline 1. Título do Cargo: Auxiliar Administrativo \\
\hline 2. Unidade: Contabilidade (setor controle patrimonial) \\
\hline 3. Descrição das Atividades: auxiliar nas diversas atividades desenvolvidas na área contábil, \\
nos setores de contabilização, fiscal e controle patrimonial. \\
\hline 4. Especificações \\
\hline 4.1. Instrução: \\
superior completo. \\
4.2. Conhecimentos: \\
informática; R/3. \\
4.3. Especialização: \\
não é necessário. \\
4.4. Experiência: \\
não é necessário. \\
4.5. Responsabilidade: \\
sobre as atividades da área. \\
4.6. Habilidades intelectuais: \\
senso crítico; capacidade de análise; iniciativa; habilidades numéricas. \\
4.7. Habilidades interpessoais: \\
bom relacionamento interpessoal. \\
4.8. Habilidades de comunicação: \\
facilidade em comunicação.
\end{tabular}

O ocupante deste cargo atua, especificamente, no setor de controle patrimonial, auxiliando o assistente desse setor em suas atividades. Ele era estagiário e foi contratado pela empresa para auxiliar na atividade de levantamento dos bens da empresa.

\section{Descrição do cargo relacionado à Contabilidade Gerencial}

Não existe, formalmente, a área de Controladoria na Empresa 2. Todavia, foi criada no final de 2001 a área de Assessoria de Custos, cujo único cargo a ela pertencente é o de Assessor de Custos, com o objetivo de, no futuro, fazer dela a Controladoria da Empresa 2.

Desde a sua criação, a área está concentrada em organizar as atividades referentes a custos gerenciais e orçamentos, e também auxiliando as diversas outras áreas da empresa quanto a questões gerenciais. Essas atividades referem-se à Contabilidade Gerencial.

Vencida essa primeira etapa, o objetivo para o futuro é caminhar no sentido de implementar outras atividades, como por exemplo, a avaliação de desempenho, que já teve início, de forma a se transformar na área de Controladoria. 
Quadro n 2.1 - Descrição do cargo Assessor de Custos

\begin{tabular}{|c|c|}
\hline & 1. Título do Cargo: Assessor de Custos \\
\hline & 2. Unidade: Assessoria de Custos \\
\hline & $\begin{array}{l}\text { 3. Descrição das Atividades: } \\
\text { orientar a elaboração de orçamentos; realizar o controle e a análise de orçamentos; realizar } \\
\text { análise gerencial de custos, dando suporte aos gerentes em como obter as informações que } \\
\text { desejam e esclarecendo as dúvidas; acompanhar a elaboração do custo padrão; acompanhar a } \\
\text { comparação do custo-padrão e do custo-real para identificar a necessidade de revisão do } \\
\text { padrão; controlar o módulo PP; acompanhar metas e controlar remuneração variável; } \\
\text { preparar material e coordenar as reuniões de apresentação de resultados, dando suporte aos } \\
\text { gerentes. }\end{array}$ \\
\hline & 4. Especificações \\
\hline & $\begin{array}{l}\text { 4.1. Instrução: } \\
\text { graduação em Ciências Contábeis. } \\
\text { 4.2. Conhecimentos: } \\
\text { todos os processos da empresa; inglês; R/3. } \\
\text { 4.3. Especialização: } \\
\text { não é necessário. } \\
\text { 4.4. Experiência: } \\
\text { não mencionou necessidade. } \\
\text { 4.5. Responsabilidade: } \\
\text { pelas atividades previstas. } \\
\text { 4.6. Habilidades intelectuais: } \\
\text { argumentação; facilidade com números; raciocínio lógico; análise crítica; perfil } \\
\text { questionador. } \\
\text { 4.7. Habilidades interpessoais: } \\
\text { bom relacionamento interpessoal; valorizar o ser humano. } \\
\text { 4.8. Habilidades de comunicação: } \\
\text { facilidade em comunicação. }\end{array}$ \\
\hline
\end{tabular}

O cargo foi criado com o foco de realizar o mínimo de atividades operacionais. O objetivo é encontrar formas melhores de resolver os problemas de informação para apoio aos gestores. No início, foi preciso organizar as informações relacionadas a custos gerenciais e também implementar orçamentos, o que significou agregar diversas atividades operacionais.

A intenção é contratar mais uma pessoa para a área de assessoria de custos e transferir para essa pessoa as atividades operacionais que estão com o assessor de custos.

Uma atividade que acabou sendo agregada ao cargo de assessor de custos, mas que não deveria estar sob sua responsabilidade, é o controle do módulo PP do R/3. Esse módulo diz respeito ao planejamento de produção e deveria estar sob a responsabilidade da área de produção. Todavia, estavam ocorrendo muitos problemas com esse módulo, porque não havia pessoas com condições de trabalhar adequadamente nele. Esses problemas afetavam os custos. Para conseguir organizar os custos, foi preciso que o ocupante desse cargo assumisse o módulo PP. De início, pensava-se que o problema estava em CO, mas, passado algum tempo, verificou-se que o problema estava no módulo PP. Este funcionário foi um dos membros da 
equipe de projeto de PP e, portanto, era qualificado para trabalhar com o mesmo.

Para desempenhar a contento as atividades previstas para este cargo, segundo seu ocupante, “A vivência de conhecer o negócio é extremamente importante.” 